ESCOLA POLITÉCNICA DA UNIVERSIDADE DE SÃO PAULO

KATIA CRISTINA DA CRUZ SILVA

DIGESTÃO DE RESÍDUOS SÓLIDOS ORGÂNICOS EM UM REATOR ANAERÓBIO OPERADO EM BATELADAS SEQUENCIAIS COM SEPARAÇÃO DA BIOMASSA

São Paulo 
Página intencionalmente deixada em branco. 
KATIA CRISTINA DA CRUZ SILVA

\section{DIGESTÃO DE RESÍDUOS SÓLIDOS ORGÂNICOS EM UM REATOR ANAERÓBIO OPERADO EM BATELADAS SEQUENCIAIS COM SEPARAÇÃO DA BIOMASSA}

Dissertação apresentada à Escola Politécnica da Universidade de São Paulo para Obtenção do Título de Mestre em Engenharia Civil

Área de Concentração:

Engenharia Hidráulica e Ambiental Orientador: Profa. Livre-Docente Dione Mari Morita 
Este exemplar foi revisado e corrigido em relação à versão original, sob responsabilidade única do autor e com a anuência de seu orientador.

Såo Paulo, de de

Assinatura do autor:

Assinatura do orientador:

Silva, Katia Cristina da Cruz

Digestăo de residuos sólidos orgânicos em um reator anaeróbio operado em bateladas sequenciais com separação da biomassa / K. C. C. Silva -- versão corr. -- São Paulo, 2016.

$164 \mathrm{p}$.

Dissertação (Mestrado) - Escola Politécnica da Universidade de São Paulo. Departamento de Engenharia de Hidráulica e Ambiental.

1.Tratamento de residuos sólidos orgânicos 2.Digestăo anaeróbia 3.Biometanizaçăo 4.Reator operado em bateladas sequenciais 5.Filtro anaeróbio I.Universidade de Săo Paulo. Escola Politécnica. Departamento de Engenharia de Hidráulica e Ambiental II.t. 
Dedico este trabaltho à minha família e amigos, Em especial ao Ronan Contrera.

Dedico também a todos que, de alguma forma, contribuíram e tornaram possivel a realização deste mestrado. 


\section{AGRADECIMENTOS}

À Deus pelas oportunidades e lições que vivi;

Aos meus pais pela força, amor e carinho;

À professora Dione Morita, pela orientação e ensinamentos, amizade, e o apoio durante a realização deste trabalho;

Agradeço a um anjo que iluminou meu caminho nos momentos mais obscuros, que me deu apoio, carinho e constantes alegrias, meu querido Ronan e a nossa Cristal;

Aos meus amigos pelo apoio, incentivo e momentos de descontração, em especial a Emília, a Carol e a Erika;

Aos meus colegas de mestrado Lara, Fábio, Lina e Marcus, por suas contribuições e por nossas reuniões semanais;

Ao professor Valdir Schalch, pelas contribuições e por ter cedido e emprestado equipamentos essenciais para realização dessa pesquisa;

Ao professor Théo, pelas contribuições na qualificação e pela agradável convivência no Departamento;

À professora Liséte Lange pelas contribuições durante a defesa do presente trabalho;

Aos professores Pedro Além Sobrinho, Roque Passos Piveli e Sidney Seckler pela troca de ideias e por todo aprendizado que me proporcionaram;

Ao CNPQ pela bolsa de mestrado concedida;

Aos funcionários do Departamento de Engenharia Hidráulica e Ambiental, em especial a Wandréa e a Ângela, por toda colaboração e orientação com os trâmites administrativos que facilitam imensamente minha vida durante esse período de mestrado;

Aos técnicos e profissionais dos diversos laboratórios que tornaram possível a realização de minhas análises, em especial a Eloisa Pozzi, ao Júlio Trofino, ao Laerte Carvalho, a Maria Ângela Adorno, a Michele Rocha, ao Renato Contessoto e a Sheila Schuindt, pela disponibilidade, disposição, paciência, ensinamentos e colaboração na realização das análises. 
"Toda conquista começa com a decisão de tentar." (autor desconhecido) 


\section{RESUMO}

Com a Política Nacional dos Resíduos Sólidos (2010), novas diretrizes foram estabelecidas, seguindo tendências modernas de se priorizar o reúso, a reciclagem e o tratamento em relação à disposição final, todavia, a implantação dessas diretrizes ainda está longe de ser realidade no Brasil. Atualmente, um dos grandes desafios é o tratamento da fração orgânica dos resíduos sólidos, que compõe entre $50 \%$ e $60 \%$ da massa dos resíduos sólidos urbanos coletados no Brasil. Visando-se o aprimoramento da tecnologia de biodigestão para tratamento dessa fração, este trabalho propôs um sistema de duas fases, no qual a biomassa anaeróbia fica retida em um meio suporte, buscando-se dessa forma, preservá-la, uma vez que seu crescimento é lento. Os reatores experimentais foram um filtro anaeróbio e um reator hidrolítico, também denominado reator de resíduos. Adicionalmente, utilizou-se lixiviado de aterro sanitário como líquido de recirculação entre as fases do sistema, atuando como alcalinizante e condutor da matéria orgânica hidrolisada com fluxo em sentido ascensional em ambos os reatores, com geração de biogás predominantemente no filtro anaeróbio. Com tempos de reação de 22 dias, para operação a $32^{\circ} \mathrm{C}$, e 32 dias, para operação a $25^{\circ} \mathrm{C}$, a produção de biogás não foi influenciada significantemente pelo aumento da taxa de recirculação de líquidos (12 para 24 ciclos por dia), sendo estas taxas suficientes para o sistema se comportar como mistura completa. As produções médias de metano foram de 0,42 $\mathrm{L}_{\text {Metano. }} \mathrm{gsTV}^{-1}$ $\left(32^{\circ} \mathrm{C}\right.$ e 12 ciclos $\left./ \mathrm{d}\right), 0,37 \mathrm{~L}_{\text {Metano.9 }} \mathrm{STV}^{-1}\left(32^{\circ} \mathrm{C}\right.$ e 24 ciclos $\left./ \mathrm{d}\right)$ e $0,30 \mathrm{~L}_{\text {Metano.9STV }}{ }^{-1}$ (25 ${ }^{\circ} \mathrm{C}$ e 24 ciclos/d). Desde o início das bateladas, o biogás apresentou $50 \%$ de metano, e esta porcentagem cresceu ao longo do tempo, atingindo cerca de $70 \%$ a $85 \%$ ao final das bateladas. Apesar da separação das fases, observou-se a colonização de morfologias hidrolíticas e metanogênicas nos resíduos do reator hidrolítico. Destarte, pode-se concluir que a configuração proposta, em qualquer uma das condições testadas, possui grande potencial para ser utilizado no tratamento da fração orgânica dos resíduos sólidos urbanos.

Palavras-chave: Resíduos sólidos orgânicos, Digestão anaeróbia, Biometanização, Reator operado em bateladas sequenciais, Filtro anaeróbio. 


\begin{abstract}
With the development of the National Policy of Solid Waste (2010), new guidelines were established, following modern trends of prioritizing reuse, recycling and treatment instead of final disposal, however, the implementation of these guidelines is still far from reality in Brazil. Currently, a great challenge is the treatment of the organic fraction of solid waste, which represents from $50 \%$ to $60 \%$ of the total mass of municipal solid waste collected in Brazil. Aiming to improve digestion technology for the treatment of this fraction, this study proposes a two-phase system, in which the anaerobic biomass is retained in a support medium, in order to preserve it, since its growth is slow. The experimental reactors were an anaerobic filter, and a hydrolytic reactor, also called waste reactor. Furthermore, landfill leachate was used as recirculating liquid between the phases of the system, acting as alkalizing and conductive of organic hydrolyzed material with upward flow direction in both reactors, generating biogas predominantly in the anaerobic filter. With 22 days of reaction time for operation at $32^{\circ} \mathrm{C}$, and 32 days for operation at $25^{\circ} \mathrm{C}$, the biogas production was not significantly influenced by increased of leachate recirculation rate (12 to 24 cycles per day), and these rates were sufficient cause complete mixing complete mixture. The average methane productions were $0,42 \mathrm{~L}_{\mathrm{CH} 4} \cdot \mathrm{gsTV}^{-1}\left(32^{\circ} \mathrm{C}\right.$ and 12 cycles/d), 0,37

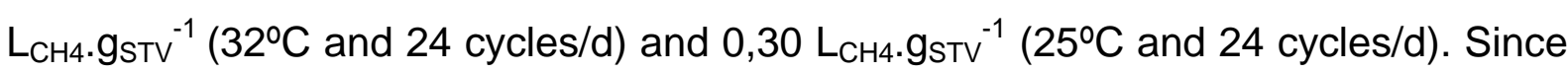
the beginning of the batches, biogas had $50 \%$ of methane in its composition, and this percentage increased over time, reaching about $70 \%$ to $85 \%$ at the end of the batches. Despite the separation of the phases, colonization of hydrolytic and methanogenic morphologies were observed in residues in the hydrolytic reactor. Therefore, it can be concluded that the proposed configuration, in any of the tested conditions, has great potential for use in the treatment of the organic fraction of municipal solid waste..
\end{abstract}

Keywords: Organic Solid Waste, Anaerobic Digestion, Biomethanization, Sequential Bach Reactor, Anaerobic filter. 


\section{LISTA DE FIGURAS}

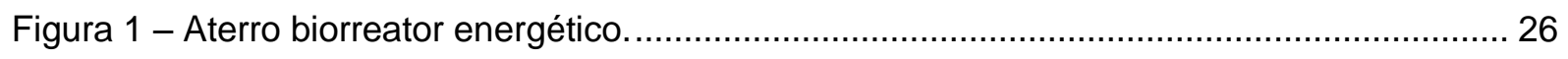

Figura 2 - Relação entre as destinações finais de RSU no Brasil entre 2007 e 2013. ................ 29

Figura 3 - Geração per-capita de resíduos e relação entre as destinações na União Europeia

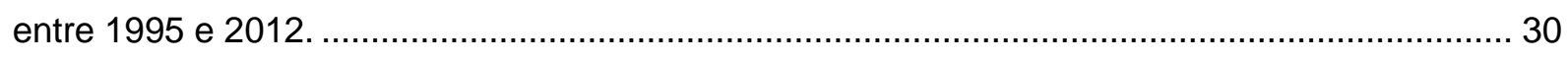

Figura 4 - Relação entre as destinações dos resíduos na União Europeia em 2012 . ................. 30

Figura 5 - Aumento da capacidade instalada de digestão anaeróbia por milhões de habitantes

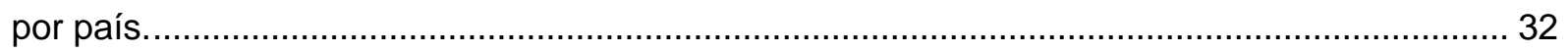

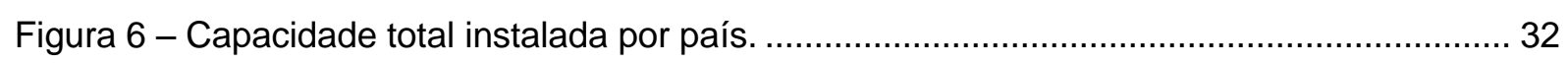

Figura 7 - Destinações dos RSU nos EUA de 1960 a 2012 ..................................................... 33

Figura 8 - RSU na China: (a) Quantidades geradas de 1979 a 2009 e (b) Destinações em 2009.

Figura 9 - Proporções entre as frações dos RSU em função das rendas dos países. ................ 37

Figura 10 - Relação entre a geração de resíduos e a renda per capita anual de alguns países. 37

Figura 11 - Geração per capita de resíduos de alguns países membros da OECD em 2011..... 38

Figura 12 - Destinação e disposição dos RS de alguns países membros da OECD em 2011. .. 38

Figura 13 - Frações dos RSU da Cidade de São Paulo entre 1927 e 2007. .............................. 41

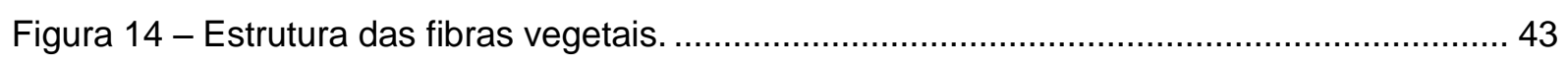

Figura 15 - Diagrama ternário: Proporção percentual de Voláteis $(\mathrm{v})$ x Inertes (I) x Umidade (U)

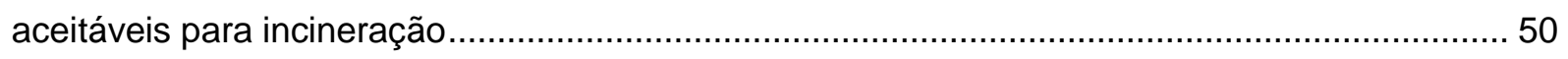

Figura 16 - Fases da estabilização da matéria orgânica na compostagem ............................... 52

Figura 17: Sequências metabólicas da digestão anaeróbia (com redução de sulfato [---]).......... 54

Figura 18: Faixas de temperaturas dos micro-organismos psicrófilos, mesófilos e termófilos..... 58

Figura 19 - Digrama simplificado de diferentes processos de digestão anaeróbia. (A) Kompogas,

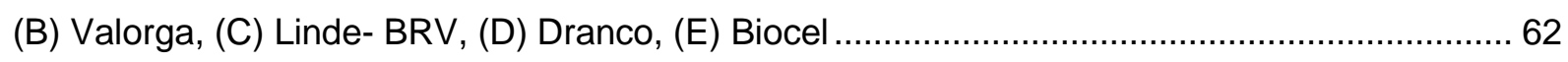

Figura 20 - Composição das amostras com as frações picadas da matéria orgânica dos resíduos

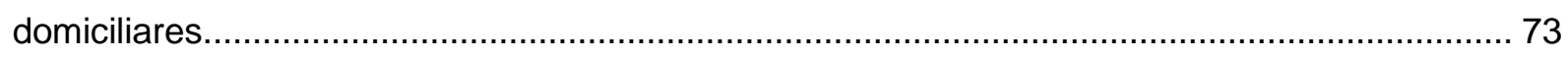

Figura 21 - Local de coleta do inóculo no fundo de uma lagoa de lixiviados do antigo aterro

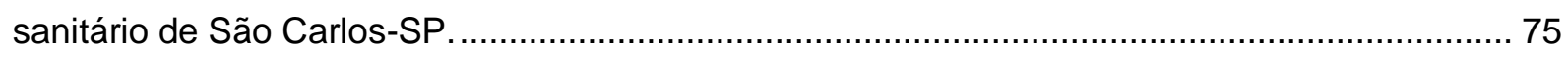

Figura 22 - (a) Inóculo antes da preparação e (b) meio suporte antes e depois da inoculação.. 75 Figura 23 - Esquema do aparato experimental utilizado na pesquisa com o filtro anaeróbio à esquerda e o reator de resíduos à direita (medidas em $\mathrm{cm})$......................................................... 77

Figura 24 - (a) Sistema de aquecimento e circulação de ar e (b) controlador de temperatura. .. 78 Figura 25 - (a) Reator de resíduos, (b) suporte com tela e difusor de líquidos e (c) Suporte e

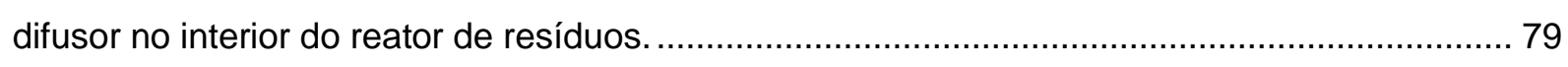

Figura 26 - Saco de náilon para contenção dos resíduos: (a) fora e (b) dentro do reator........... 79

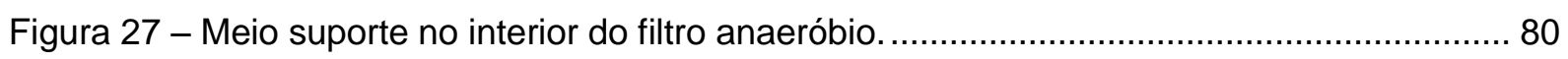


Figura 28 - (a) Bomba de recirculação de líquidos, (b) Frasco de Mariotte e (c) Fração de $\mathrm{CH}_{4}$ estimada por reação do $\mathrm{CO}_{2} \mathrm{com} \mathrm{NaOH}$.

Figura 29 - Montagem completa do aparto experimental dentro do armário com controle de temperatura.

Figura 30 - Produção de biogás da batelada zero: (a) Diária e (b) Acumulada. .......................... 89

Figura 31 - Temperaturas operacionais nas diferentes fases do experimento. .......................... 90

Figura 32 - Produções acumuladas de biogás nas diferentes fases do experimento.................. 92

Figura 33 - Produções percentuais acumuladas de biogás nas diferentes fases do experimento.

Figura 34 - Produções diárias de biogás nas diferentes fases do experimento. 95

Figura 35 - Produções diárias de biogás com base nas concentrações iniciais de STV nas diferentes fases do experimento.

Figura 36 - Proporção percentual volumétrica de metano do biogás nas diferentes fases do

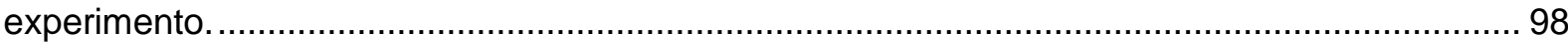

Figura 37 - Variações do pH nas diferentes fases do experimento........................................... 105

Figura 38 - Variações da Alcalinidade Total nas diferentes fases do experimento. 108

Figura 39 - Variações das concentrações de Ácidos Voláteis Totais por titulação nas diferentes fases do experimento. 110 Figura 40 - Variações de parâmetros entre os amostradores A e B*: (a) pH Fase 01; (b) pH Fase 2; (c) AT Fase 1; (d) AT Fase 2; (e) AVT por titulação na Fase 1 e (f) AVT por titulação na Fase 2. .

Figura 41 - Concentrações de ácidos voláteis por cromatografia de amostras coletadas nos amostradores A e B* na batelada 05 (Fase 01).

Figura 42 - Concentrações de ácidos voláteis por cromatografia de amostras coletadas nos amostradores A e $B^{\star}$ na batelada 11 (Fase 03).

Figura 43 - Variações das concentrações de Carbono Orgânico Total nas diferentes fases do experimento.

Figura 44 - Variações das concentrações de Sólidos Dissolvidos Voláteis nas diferentes fases do experimento.

Figura 45 - Variações das concentrações de Sólidos Dissolvidos Fixo nas diferentes fases do experimentos.

Figura 46 - Variações da Condutividade nas diferentes fases do experimento.

Figura 47 - Variações das concentrações de $\mathrm{N}$-amoniacal nas bateladas 06, 08 e 12. 120

Figura 48 - Imagens de microscopia ótica do resíduo tratado apresentando diversidade de morfologias.

Figura 49 - Imagens de MEV do resíduo tratado.

Figura 50 - Variações das concentrações de Sólidos em Suspensão Voláteis nas diferentes fases do experimento. 
Figura 51 - Morfologias identificadas nas imagens de microscopia ótica do lodo de inóculo.... 134

Figura 52 - Imagens de microscopia eletrônica de varredura do lodo de inóculo.

Figura 53 - Morfologias identificadas nas imagens de microscopia ótica do lodo extraído da espuma ao final do experimento.

Figura 54 - Morfologias identificadas nas imagens de microscopia eletrônica de varredura do lodo extraído da espuma ao final do experimento.................................................................. 135

Figura 55 - Imagem de microscopia eletrônica de varredura da espuma colonizada. 136

Figura 56 - Imagens de microscopia eletrônica de varredura do lodo aderido à espuma ao final do experimento. 136

Figura 57 - Variações das concentrações de Sólidos Totais nas diferentes fases do experimento.

Figura 58 - Variações das concentrações de Sólidos Totais Voláteis nas diferentes fases do experimento fases.

Figura 59 - Variações das concentrações de Sólidos Totais Fixos nas diferentes fases do experimento.

Figura 60 - Variações das concentrações de Sólidos em Suspensão Fixos nas diferentes fases do experimento. 156

Figura 61 - Variações das concentrações de Sólidos Suspensos Totais nas diferentes fases do experimento.

Figura 62 - Variações das concentrações de Sólidos Dissolvidos Totais nas diferentes fases do experimento. 158

Figura 63 - Variações das concentrações de metais nas bateladas 04, 06 e 08: (a) Cromo; (b)

Cobre; (c) Chumbo e (d) Níquel. 159

Figura 64 - Variações das concentrações de metais nas bateladas 04, 06 e 08: (a) Zinco; (b) Selênio; (c) ) Sódio e (d) Potássio. 160

Figura 65 - Variações das concentrações de Sódio nas diferentes fases do experimento. ....... 161

Figura 66 - Variações das concentrações de Potássio nas diferentes fases do experimento... 162 Figura 67 - Variações das concentrações de Cálcio nas diferentes fases do experimento........ 163 Figura 68 - Variações das concentrações de Magnésio nas diferentes fases do experimento. 164 


\section{LISTA DE TABELAS}

Tabela 1 - Quantidade de resíduos sólidos domiciliares e/ou públicos encaminhados para disposição em solo, considerando apenas lixão, aterro controlado e aterro sanitário (t/dia)....... 28 Tabela 2 - Composição percentual dos resíduos gerados, recuperados e dispostos em aterros nos EUA em 2012.

Tabela 3 - Informações sobre a gestão dos resíduos sólidos no Japão entre os anos fiscais de 2000 a 2013.

Tabela 4 - Estimativa da composição gravimétrica dos resíduos sólidos coletados no Brasil. ... 39

Tabela 5 - Caracterização dos RSU de algumas cidades brasileiras.

Tabela 6 - Faixas do teor de umidade dos componentes da fração orgânica dos RSU e seus valores típicos

Tabela 7 - Composição nutricional média de resíduos orgânicos putrescíveis de diferentes fontes (\% com base na massa seca).

Tabela 8 - Concentrações características de alguns componentes vegetais da FORSU.

Tabela 9 - Composição química de aparas de jardinagem.

Tabela 10 - Composição média das frações putrescíveis dos RSU e RD ao longo de um ano. . 45

Tabela 11 - Faixas de concentração das principais variáveis de caracterização de lixiviados de aterros sanitários brasileiros e americanos e europeus.

Tabela 12 - Estimativa percentual de matéria orgânica tratada em relação ao total coletado. ... 49

Tabela 13 - Comparação entre a composição do biogás e a do gás natural. ............................... 56

Tabela 14 - Composição química dos micro-organismos metanogênicos.

Tabela 15 - Dados de desempenho de diferentes processos de digestão anaeróbia aplicadas para o tratamento de resíduos sólidos orgânicos (continua).

Tabela 16 - Dados de desempenho de diferentes filtros anaeróbios aplicados ao tratamento de lixiviados de aterro sanitário.

Tabela 17 - Composição de cada uma das amostras de acordo com suas frações constituintes.

Tabela 18 - Caracterização do lixiviado procedente do aterro de Paulínia-SP............................ 76

Tabela 19 - Amostragens de líquidos e gases ao longo das bateladas. ...................................... 82

Tabela $20-2^{\mathrm{a}}$ Etapa experimental: fases de operação do sistema. 83

Tabela 21 - Variáveis determinadas, tipo de amostra e metodologia analítica utilizada na

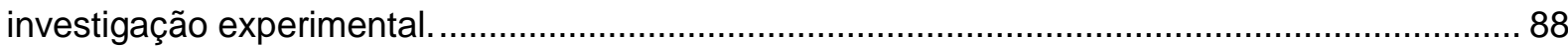

Tabela 22 - Comparação entre metodologias para determinação da composição do biogás. .... 99

Tabela 23 - Volumes totais de biogás produzidos nas bateladas 01 a 14 .............................. 100

Tabela 24 - Volumes totais de metano produzidos nas bateladas 01 a $14 \ldots \ldots \ldots \ldots \ldots \ldots \ldots \ldots \ldots . . . . . . . . . . . . .101$

Tabela 25 - Dados utilizados para análise comparativa entre as Fases 02 e 03...................... 102

Tabela 26 - Cálculos e considerações para análise comparativa. .............................................. 103

Tabela 27 - Resultados obtidos na análise comparativa entre as Fases 02 e 03.................... 104 
Tabela 28 - Determinação da relação entre a alcalinidade total disponível e a concentração inicial de substrato no sistema para as 4 fases de operação (MAT/MSTV).

Tabela 29 - Caracterização dos resíduos crus em termos de sólidos. 121

Tabela 30 - Caracterização dos resíduos crus e tratados, e eficiências de remoção na Fase de Adaptação ( $32^{\circ} \mathrm{C}$ e $\left.12 \mathrm{X}\right)$. 121

Tabela 31 - Caracterização dos resíduos crus e tratados, e eficiências de remoção

na Fase $01\left(32^{\circ} \mathrm{C}\right.$ e $\left.12 \mathrm{X}\right)$ 122

Tabela 32 - Caracterização dos resíduos crus e tratados, e eficiências de remoção na Fase 02 $32^{\circ} \mathrm{C}$ e $24 \mathrm{X}$ (continua). 122

Tabela 33 - Caracterização dos resíduos crus e tratados, e eficiências de remoção na Fase 03 $25^{\circ} \mathrm{C}$ e $24 \mathrm{X}$ 123

Tabela 34 - Composição elementar dos resíduos. 124

Tabela 35 - Relação C:H:N:P dos resíduos. 125

Tabela 36 - Concentrações de metais dos resíduos tradados e não digerido [mg/kg]. 126

Tabela 37 - Caracterização da biomassa aderida ao meio suporte. 129

Tabela 38 - Relações entre parâmetros da biomassa e meio suporte 131

Tabela 39 - Teores de metais na biomassa anaeróbia antes e depois da operação do sistema, com base no teor de ST [mg/kgST]. 133

Tabela 40 - Teores de metais na biomassa anaeróbia antes e depois da operação do sistema, com base no teor de STV [mg/kgSTV]. 


\section{LISTA DE ABREVIATURAS, SIGLAS E SIMBOLOS}

\begin{tabular}{|c|c|}
\hline ABNT & Associação Brasileira de Normas Técnicas \\
\hline \multirow[t]{2}{*}{ ABRELPE } & Associação Brasileira de Empresas de Limpeza Pública e Resíduos \\
\hline & Especiais \\
\hline AGV & Ácidos graxos voláteis \\
\hline APHA & American Public Health Association \\
\hline AT & Alcalinidade Total \\
\hline AVT & Ácidos Voláteis Totais \\
\hline AWWA & American Water Works Association \\
\hline BRE & Biofiltros de Resíduos Envelhecidos \\
\hline CETESB & Companhia Ambiental do Estado de São Paulo \\
\hline CGR & Centro de Gerenciamento de Resíduos \\
\hline CNPq & Conselho Nacional de Desenvolvimento Científico e Tecnológico \\
\hline COT & Carbono Orgânico Total \\
\hline DBO & Demanda Bioquímica de Oxigênio \\
\hline DQO & Demanda Química de Oxigênio \\
\hline EC & European Community \\
\hline EEC & Comunidade Econômica Europeia \\
\hline EESC-USP & Escola de Engenharia de São Carlos (USP) \\
\hline Eh & Potencial redox \\
\hline EPA & Environmental Protection Agency \\
\hline EP-USP & Escola Politécnica da Universidade de São Paulo \\
\hline EU & União Europeia \\
\hline EUA & Estados Unidos \\
\hline FORSU & Fração Orgânica dos Resíduos Sólidos Urbanos \\
\hline $\mathbf{F} / \mathbf{M}$ & Relação alimento/microrganismo \\
\hline IBGE & Instituto Brasileiro de Geografia e Estatística \\
\hline ICP-AES & Espectrometria de Emissão Atômica com Plasma Induzido \\
\hline IPEA & Instituto de Pesquisa Econômica Aplicada \\
\hline IQR & Índice de Qualidade dos Resíduos \\
\hline ITRC & Interstate Technology \& Regulatory Council Alternative Landfill Technologies \\
\hline \multicolumn{2}{|l|}{ Team } \\
\hline $\mathrm{L}_{\text {Bob }}$ & Comprimento do bob do meio suporte do filtro anaeróbio \\
\hline LPB & Laboratório de Processos Biológicos \\
\hline Limpurb & Departamento de Limpeza Urbana \\
\hline $\mathbf{M}_{\mathrm{AT}}$ & Massa de alcalinidade total \\
\hline
\end{tabular}




\begin{tabular}{|c|c|}
\hline MAPA & Ministério da Agricultura, Pecuária e Abastecimento \\
\hline$M_{\text {Bob }}$ & Massa do bob do meio suporte do filtro anaeróbio \\
\hline$M_{\text {Esp }}$ & Massa de espuma do meio suporte do filtro anaeróbio \\
\hline $\mathbf{M}_{\mathrm{STV}}$ & Massa de sólidos totais voláteis \\
\hline MEV & Microscopia eletrônica de varredura \\
\hline $\mathbf{M}_{\mathrm{MS}}$ & Massa de meio suporte (bob + espuma) do filtro anaeróbio \\
\hline OECD & Organisation for Economic Co-operation and Development \\
\hline PEBD & Polietileno de baixa densidade \\
\hline PMSP & Prefeitura do Município de São Paulo \\
\hline PNRS & Política Nacional dos Resíduos Sólidos \\
\hline PVC & Cloreto de Polivinila \\
\hline RD & Resíduo Domiciliar \\
\hline RLU & Resíduo de Limpeza Urbana \\
\hline RSU & Resíduo Sólido Urbano \\
\hline SHS & Departamento de Hidráulica e Saneamento \\
\hline SNIS & Sistema Nacional de Informações sobre Saneamento \\
\hline ST & Sólidos Totais \\
\hline STF & Sólidos Totais Fixos \\
\hline STV & Sólidos Totais Voláteis \\
\hline SST & Sólidos em Suspensão Totais \\
\hline SSF & Sólidos em Suspensão Fixos \\
\hline SSV & Sólidos em Suspensão Voláteis \\
\hline SDT & Sólidos Dissolvidos Totais \\
\hline SDF & Sólidos Dissolvidos Fixos \\
\hline SDV & Sólidos Dissolvidos Voláteis \\
\hline TDH & Tempo de Detenção Hidráulico \\
\hline UNEP & United Nations Environment Programme \\
\hline USP & Universidade de São Paulo \\
\hline $\mathbf{V}_{\text {Esp }}$ & Volume de espuma do meio suporte do filtro anaeróbio \\
\hline $\mathbf{Y}_{\mathbf{X} / \mathbf{S}}$ & Coeficiente de produção celular \\
\hline WEF & Water Environment Federation \\
\hline$\alpha$ & $\begin{array}{l}\text { Coeficiente angular do primeiro trecho da curva de produção acumulada de } \\
\text { biogas ao longo do tempo }\end{array}$ \\
\hline$\beta$ & $\begin{array}{l}\text { Coeficiente angular do segundo trecho da curva de produção acumulada de } \\
\text { biogas ao longo do tempo }\end{array}$ \\
\hline$\gamma$ & $\begin{array}{l}\text { Coeficiente angular do terceiro trecho da curva de produção acumulada de } \\
\text { biogas ao longo do tempo }\end{array}$ \\
\hline
\end{tabular}




\section{SUMÁRIO}

1 INTRODUÇÃO

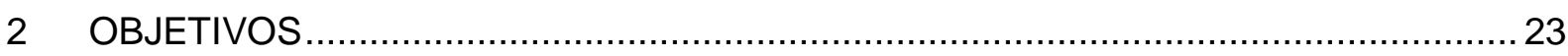

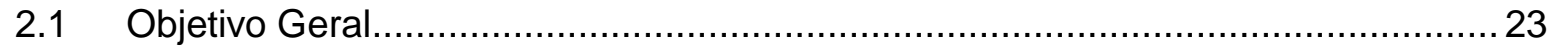

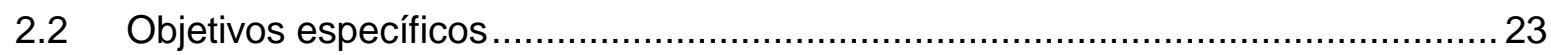

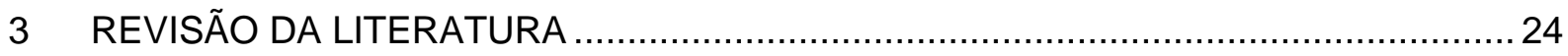

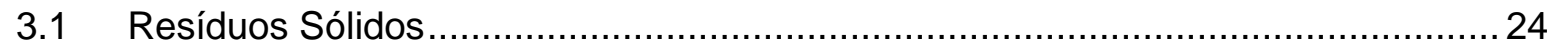

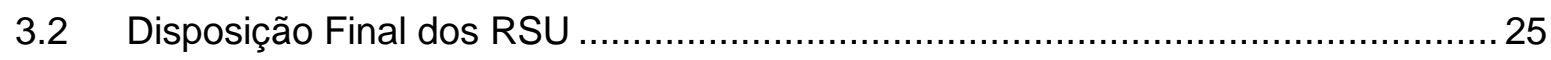

3.3 Panorama Geral dos RSU no Brasil e no Mundo ................................................2

3.4 Caracterização dos RSU Gerados no Brasil ......................................................... 39

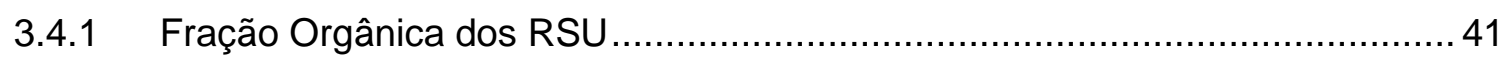

3.5 Lixiviados de Aterros Sanitários ........................................................................ 46

3.6 Tratamento da Fração Orgânica Putrescível dos RSU ………………………...... 48

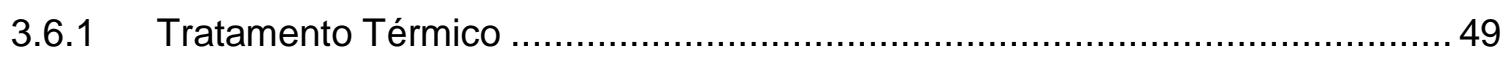

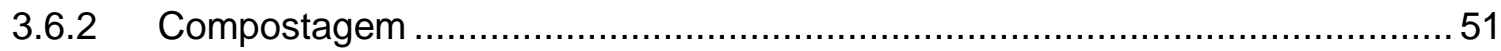

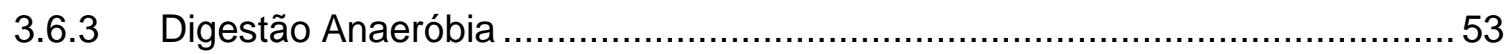

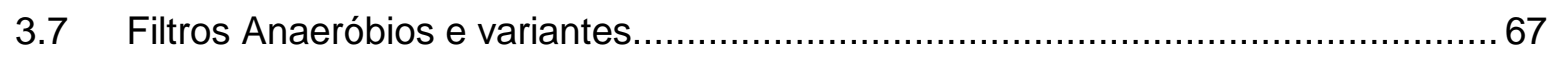

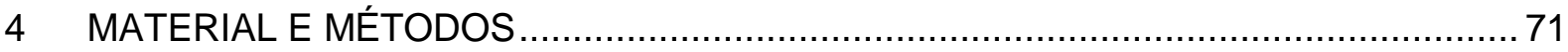

4.1 Preparação e Conservação da Matéria Orgânica ……………………………..... 71

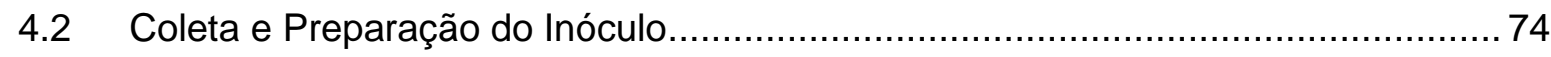

4.3 O Lixiviado de Aterro Sanitário Utilizado no Experimento …………………….....75

4.4 Montagem do Aparato Experimental............................................................. 76

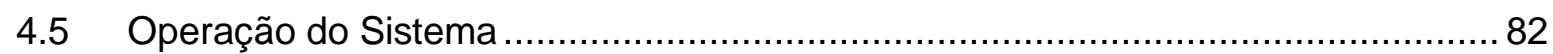

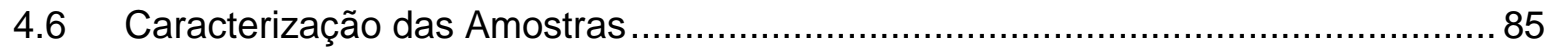

5 APRESENTAÇÃO E DISCUSSÃO DOS RESULTADOS ………….......................... 89

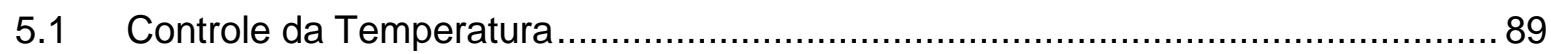

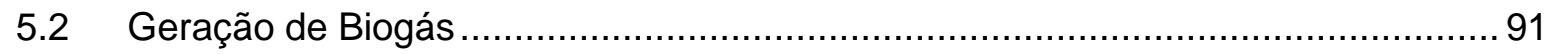

5.3 Viabilidade do Uso do Lixiviado de Aterro Sanitário como Líquido de Recirculação 104 


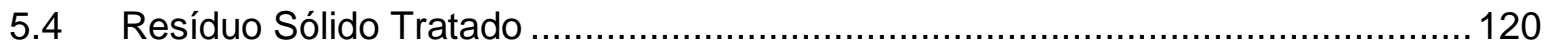

5.5 Biomassa Anaeróbia aderida ao meio suporte............................................ 129

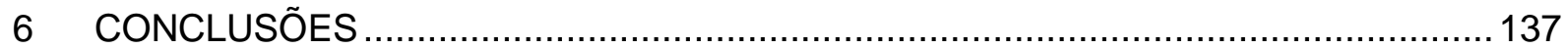

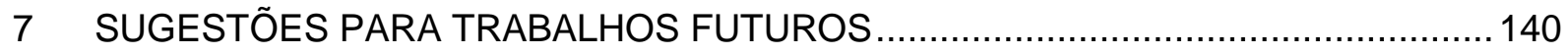

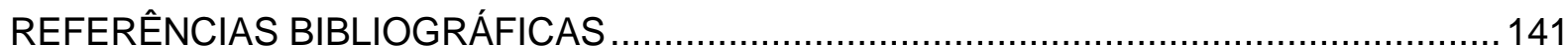

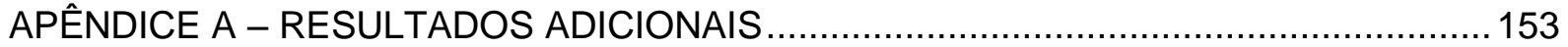




\section{INTRODUÇÃO}

Em um contexto mundial, até pouco mais de um século atrás, pouca ou quase nenhuma importância era dada à questão dos resíduos sólidos. Os países desenvolvidos, especialmente os europeus, deram um grande salto nesta questão nos últimos 25 anos, por meio de políticas e legislações mais rigorosas e avançadas, que impulsionaram o desenvolvimento e a implementação de tecnologias de tratamento e proporcionaram uma melhora significativa na gestão dos resíduos sólidos urbanos (RSU).

A política ambiental da União Europeia (EU) começou com a de resíduos. Nos anos de 1970 e 1980, uma série de problemas e escândalos relacionados com o tratamento de resíduos alertou os políticos para o potencial impacto que uma má gestão de resíduos pode ter sobre o meio ambiente e à saúde humana. Desta forma, em 1975, foi aprovada a diretiva da comunidade europeia (Dir.75/442/EEC) que estabelecia os resultados a serem obtidos pelos estados membros com relação à produção, à destinação e à disposição ambientalmente adequadas dos resíduos sólidos, mas não especificava as medidas a serem adotadas para alcançar tais resultados (JOHNSON, 2004). Em 1989, com a Convenção de Basel, um acordo ambiental multilateral foi estabelecido, abordando a produção mais limpa, a minimização de resíduos perigosos e o controle sobre a disposição destes resíduos, culminando na não aceitação da disposição no mar ou encaminhamento destes para países em desenvolvimento. Posteriormente, mais dois instrumentos legislativos foram implementados: a diretiva relativa aos resíduos perigosos (Dir.91 / 689 / CEE) e o regulamento relativo às transferências de resíduos (Reg. (CEE) n²59/93). A diretiva de 1996 sobre a Prevenção e Controle Integrados da Poluição (CD, 1996), que introduziu um sistema de autorização para combater a poluição das instalações industriais e agrícolas, estabeleceu normas para uma série de atividades relacionadas com os resíduos, bem como para as instalações em que eles pudessem ser utilizados, tais como os fornos de cimento. Outras lacunas dessa problemática foram preenchidas com legislações ambientais mais rigorosas, como as diretivas de Aterro $(C D, 1999)$ e de Incineração (CD, 2000). Estas últimas contribuíram significativamente para reciclagem de materiais e avanços nos tratamentos biológicos, bem como para diminuição de emissões de gases com efeito de estufa ou mesmo de dioxinas e furanos em incineradores (EC, 2014). 
Particularmente importante neste contexto são as restrições à disposição em aterro, introduzidas pela primeira diretiva, em especial a redução da quantidade de resíduos biodegradáveis e a proibição de determinados tipos de resíduos.

Neste panorama, dentre as muitas legislações dos países europeus, destaca-se a Portaria de 1991 - Packaging, onde a Alemanha abandonou tentativas de alcançar abordagens voluntárias para a gestão das embalagens e responsabilizou a indústria por seus resíduos por meio de uma exigência de retorno das embalagens usadas. Com o tempo, esta legislação foi alterada e evoluiu para lei de gestão de resíduos de ciclo fechado KrW- / AbfG em 1994 (JOHNSON, 2004). A proibição de aterro para RSU não tratados existe, em princípio, na Alemanha desde 1993, e sem exceções, desde 2005. Para este tipo de disposição, é necessário o pré-tratamento do resíduo, quer seja por incineração ou por tratamentos mecânicos-biológicos (NEUBAUER, 2013).

No Brasil, a problemática dos resíduos sólidos só ganhou importância com a Lei $n^{\circ}$. 12.305 (BRASIL, 2010a), regulamentada pelo Decreto 7304 (BRASIL, 2010b), que estabeleceu a Política Nacional dos Resíduos Sólidos (PNRS), na qual as municipalidades passaram a ter mais responsabilidade na gestão dos resíduos, não somente com relação à disposição final adequada, mas também com a ordem de prioridades estabelecida no artigo $9^{\circ}$ da lei: não geração, redução, reutilização, reciclagem, tratamento dos resíduos sólidos e por último, a disposição final ambientalmente adequada dos rejeitos.

Segundo a Associação Brasileira de Empresas de Limpeza Pública e Resíduos Especiais - ABRELPE (2015), a geração total de RSU no Brasil em 2014 foi de 78.583 .405 toneladas, no qual apenas $58,4 \%$ foram dispostas adequadamente em aterros sanitários.

Considerando-se que mais de $50 \%$ da massa dos RSU coletados no Brasil é composta por fração orgânica facilmente biodegradável, a situação fica ainda mais crítica, pois somente $1,6 \%$ dessa fração é tratada, sendo o restante disposto em aterros e lixões (IPEA, 2012).

Experiências no tratamento da fração orgânica ainda são incipientes no país. O resíduo orgânico, por não ser coletado em separado, acaba sendo encaminhado para disposição final junto com os demais resíduos de difícil biodegradação, que 
deixaram de ser coletados de maneira seletiva. Esta forma de destinação gera, para a maioria dos municípios, despesas que poderiam ser evitadas caso a matéria orgânica fosse separada na fonte e encaminhada para um tratamento específico, por exemplo, via digestão anaeróbia, compostagem ou tratamento térmico. Portanto, evitando-se o depósito da fração orgânica facilmente biodegradável em aterro, permite-se aumentar a sua vida útil, ou que sejam construídos aterros menores, além de contribuir para diminuição da emissão de metano nos locais onde ele não é capturado ou queimado (emissões fugitivas), minimizando, assim, o impacto no efeito estufa (NAIK, TKACHENKO, WUNG, 2013) e ainda contribui para diminuição da geração de lixiviados, que possuem elevado potencial para poluição de águas superficiais e subterrâneas. Salienta-se que o tratamento da fração orgânica em sistemas de digestão anaeróbia propicia, também, a geração de energia renovável por meio da produção de biogás, bem como a utilização do subproduto na agricultura, após tratamento adicional.

Segundo De Baere e Mattheeuws (2013), todas as áreas de gestão de resíduos na Europa tiveram um grande progresso, mas a introdução da digestão anaeróbia para o tratamento da fração orgânica dos RSU é um dos desenvolvimentos tecnológicos mais bem sucedidos e inovadores. Mesmo com a melhoria contínua de alternativas tecnológicas de tratamento, tais como gaseificação, pirólise, plasma, etc., essas tecnologias até agora não obtiveram o mesmo alcance de implementação da digestão anaeróbia, com um total de 244 usinas até 2014, uma capacidade de tratamento de cerca de 8 milhões de toneladas de resíduos orgânicos por ano, sendo a responsável por cerca de $25 \%$ do tratamento biológico na Europa.

Ainda de acordo com De Baere e Mattheeuws (2013), a digestão anaeróbia costumava ser um anátema no mundo da compostagem, sendo sempre sinônimo de problemas operacionais e de odor. Atualmente, a digestão anaeróbia e a compostagem caminham lado a lado em muitos aspectos, tanto que a primeira pode ser utilizada para substituir as primeiras fases da segunda. Isso permite que, em uma mesma área superficial, se amplie a capacidade de tratamento das unidades existentes e a redução potencial de odor, além da possibilidade de geração de energia renovável.

Dessa forma, a presente pesquisa visa 0 aprimoramento da tecnologia de biodigestão, ao propor um sistema de duas fases, no qual a biomassa anaeróbia não 
é misturada aos resíduos, buscando-se dessa forma, preservá-la em um meio suporte dentro de um filtro anaeróbio, uma vez que seu crescimento é lento. Propõese o uso de lixiviado de aterro sanitário como líquido de recirculação entre as fases do sistema, atuando como alcalinizante e condutor da matéria orgânica hidrolisada. 


\section{OBJETIVOS}

\subsection{Objetivo Geral}

Avaliar o desempenho de uma configuração de reator com separação de fases e biomassa (reator de resíduos + filtro anaeróbio) na decomposição e estabilização da fração orgânica de resíduos domiciliares, utilizando-se lixiviado de aterro sanitário velho como líquido de recirculação e alcalinizante do sistema.

\subsection{Objetivos específicos}

- Avaliar a produção de metano no biogás do resíduo estudado;

- Avaliar o efeito da variação da taxa de recirculação do lixiviado sobre a digestão anaeróbia dos resíduos;

- Avaliar a operação do sistema em temperatura ambiente, visando o tratamento descentralizado de resíduos. 


\section{REVISÃO DA LITERATURA}

\subsection{Resíduos Sólidos: Definição e Classificação}

A PNRS (Brasil, 2010a) define resíduos sólidos como qualquer material, substância, objeto ou bem descartado, resultante de atividades humanas em sociedade, cuja destinação final se procede, se propõe proceder ou se está obrigado a proceder, nos estados sólido ou semissólido, bem como gases contidos em recipientes e líquidos, cujas particularidades tornem inviável o seu lançamento na rede pública de esgoto ou em corpos d'água, ou exijam para isso soluções técnicas ou economicamente inviáveis em face da melhor tecnologia disponível. A mesma define ainda rejeitos como os resíduos sólidos que, depois de esgotadas todas as possibilidades de tratamento e recuperação por processos tecnológicos disponíveis e economicamente viáveis, não apresentem outra possibilidade que não a disposição final ambientalmente adequada.

Dentre as classificações de resíduos sólidos, têm-se a relativa à origem, de acordo com o artigo 13 da PNRS, onde os resíduos sólidos urbanos (RSU) são definidos como a soma de dois tipos de resíduos: os domiciliares (RD), que são os originários de atividades domésticas em residências urbanas; e os de limpeza urbana (RLU), que são os originários da varrição, limpeza de logradouros e vias públicas e outros serviços de limpeza urbana (Brasil, 2010a). Salienta-se que a competência para o gerenciamento destes resíduos é do poder público municipal, sendo que, segundo a Pesquisa Nacional de Saneamento Básico de 2008 do Instituto Brasileiro de Geografia e Estatística (IBGE, 2008) o total de $61,2 \%$ das prestadoras dos serviços de manejo dos resíduos sólidos são entidades vinculadas à administração direta do poder público; 34,5\% são empresas privadas sob o regime de concessão pública ou terceirização; e apenas $4,3 \%$ são entidades organizadas sob a forma de autarquias, empresas públicas, sociedades de economia mista e consórcios.

Apesar da responsabilidade municipal quanto ao serviço público de limpeza urbana e manejo de resíduos sólidos, os incisos VI e IX do art. 23 da CF/1988 estabelecem como atribuição comum da União, dos Estados, do Distrito Federal e dos municípios protegerem o meio ambiente e combater a poluição em qualquer das suas formas. Deste modo, os Estados poderão atuar por meio das Secretarias Estaduais de Meio Ambiente e a União, por meio do Ministério das Cidades e Ministério do Meio 
Ambiente, para combaterem a poluição provocada pelos resíduos sólidos, bem como contribuir para a promoção de programas de melhoria do saneamento básico (Góes, 2011).

\subsection{Disposição Final dos RSU}

A disposição final dos resíduos sólidos no Brasil ainda é feita na forma de lixões, aterros controlados e aterros sanitários, sucintamente descritos a seguir.

O lixão se caracteriza pela simples descarga dos resíduos sobre o solo, não se utilizando medidas de proteção ao meio ambiente ou à saúde pública (impermeabilização do solo, cobertura dos resíduos e drenagem de líquidos e gases). No local, não há controle do recebimento dos resíduos (tipo e quantidades) e nem controle de acesso. A inexistência de proteções da base, bem como de proteções superficiais, favorece a infiltração de lixiviados e o escoamento superficial, que contaminam os aquíferos subterrâneos ou os corpos hídricos superficiais. A falta de cobertura favorece ainda a proliferação de maus odores e vetores de doenças, tais como: insetos, roedores e aves, além do espalhamento de resíduo pelo vento.

O aterro controlado é uma forma de disposição de RSU no solo, na qual são tomadas algumas precauções, tais como a compactação dos resíduos, a conformação de taludes, a cobertura dos resíduos com solo e a instalação de drenos de gases. Embora seja uma técnica preferível em relação aos lixões, não substitui o aterro sanitário, pois pode permitir a contaminação dos aquíferos subterrâneos através da infiltração de lixiviados, devido à inexistência total ou parcial de sistemas de impermeabilização do solo (ABNT,1985; CEMPRE, 2010).

O aterro sanitário é uma forma de disposição final de RSU no solo que segue critérios de engenharia e normas operacionais específicas, proporcionando o confinamento seguro dos mesmos (normalmente, recobrindo com argila selecionada e compactada em níveis satisfatórios), evitando danos ou riscos à saúde pública e minimizando os impactos ambientais. Os critérios de engenharia mencionados materializam-se na impermeabilização prévia do solo e em projetos de sistemas de drenagem periférica e superficial para afastamento de águas de chuva, de drenagem de fundo para a coleta de lixiviado, de sistema de tratamento para o lixiviado drenado, de drenagem e queima ou reaproveitamento dos gases gerados durante 0 
processo de bioestabilização da matéria orgânica (ABNT, 1992; BIDONE E POVINELLI, 1999).

Salienta-se que até 2011, a Companhia Ambiental do Estado de São Paulo (CETESB) classificava a disposição final dos resíduos sólidos de acordo com o Índice de Qualidade dos Resíduos (IQR) em três condições: inadequadas, controladas e adequadas. Esta classificação foi alterada para adequada ou inadequada a partir de 2012 (CETESB, 2014).

Atualmente, alguns aterros sanitários de RSU também podem ser considerados energéticos, quando captam o biogás produzido e o utilizam para geração de eletricidade. O conceito de aterro energético pode ser ampliado ainda ao conceito de aterro biorreator, quando se utilizam técnicas para se acelerar a degradação da matéria orgânica e consequentemente aumentar a produção de biogás (ITRC, 2006). A Figura 1 ilustra um aterro biorreator energético, em que a aceleração da estabilização da matéria orgânica é conseguida através da recirculação de lixiviados.

Figura 1 - Aterro biorreator energético.

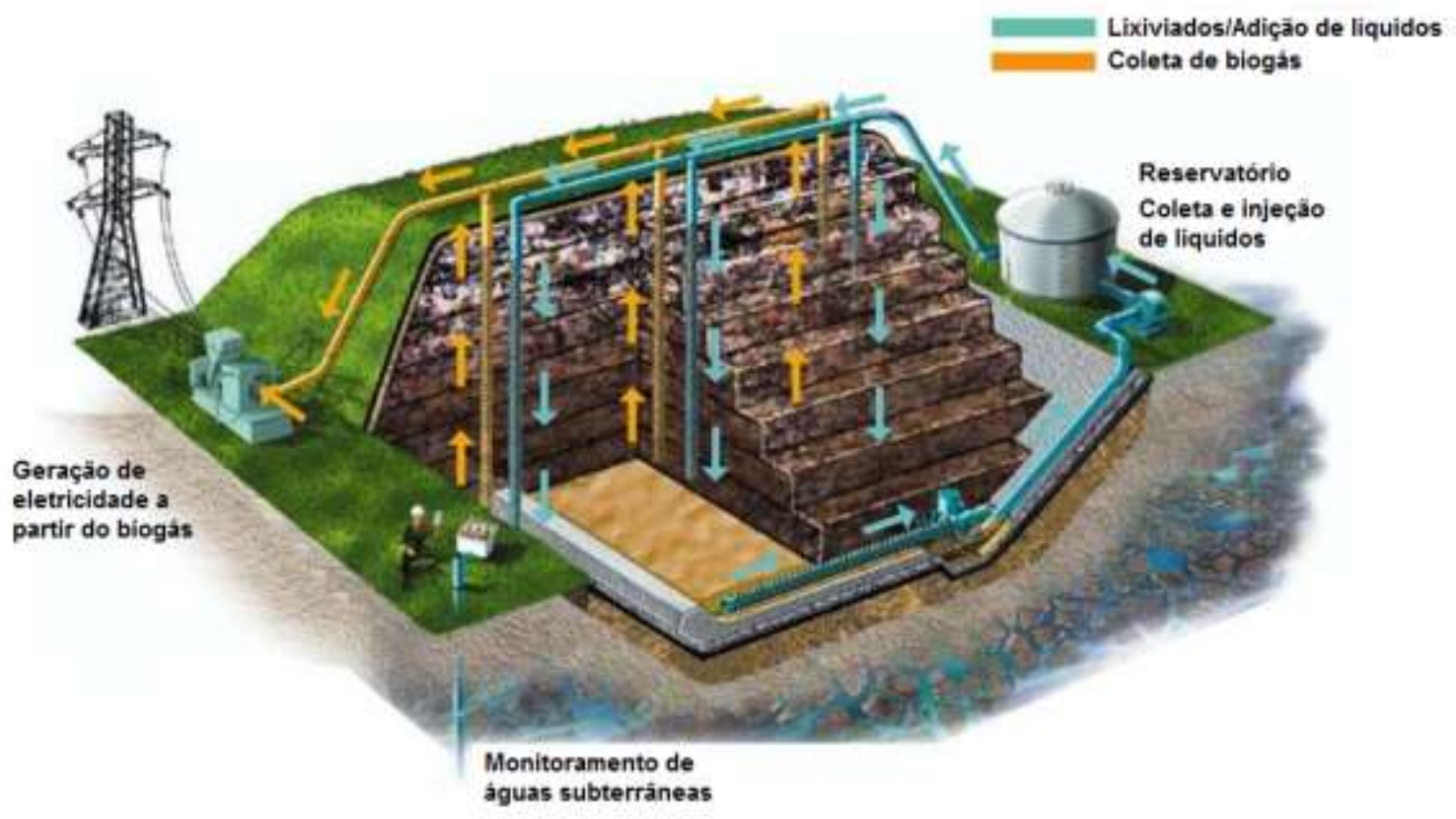

Fonte: Adaptado de WM (2004). 
Ressalta-se que regiões com clima tropical e grande pluviosidade há uma elevada produção de lixiviados nos aterros, de modo que a recirculação total dos mesmos pode ser inviável, gerando um excedente de lixiviado que deverá ser tratado de forma ambientalmente adequada. Em muitos locais, o órgão ambiental proíbe esse tipo de prática visando preservar a estabilidade estrutural dos aterros.

A PNRS colocou como limite o ano de 2014 para o fim dos lixões e dos aterros controlados. Assim, os municípios que não atingiram esta meta não estão em conformidade com a legislação vigente. Uma interpretação equivocada da mesma pode dar a entender que os lixões podem ser diretamente substituídos por aterros sanitários, quando a prioridade estabelecida deveria ser a não geração, a redução, a reutilização, a reciclagem, o tratamento dos resíduos sólidos e por último, a disposição final ambientalmente adequada dos rejeitos em aterros sanitários.

\subsection{Panorama Geral dos RSU no Brasil e no Mundo}

No Brasil, por falta de recursos ou mesmo por desinteresse das autoridades municipais, ainda é pequeno o número de municípios que dispõe adequadamente os seus resíduos sólidos. Segundo a Pesquisa Nacional de Saneamento Básico do IBGE (2008), somente cerca de $27,7 \%$ das unidades de destino final em 2008 eram aterros sanitários e 50,8\%, lixões a céu aberto. Infelizmente, a pesquisa não apresentou as quantidades totais em massa de resíduos por tipo de disposição final. Entretanto, o Instituto de Pesquisas Econômicas Aplicadas - IPEA (2012), que avaliou a evolução da disposição do RSU entre 2000 e 2008 (Tabela 1), observou que houve um aumento de $120 \%$ na quantidade de resíduos dispostos em aterros sanitários e uma redução de $18 \%$ na quantidade de resíduos encaminhada para lixões. Os municípios de pequeno e médio portes tiveram acréscimos significativos de $370 \%$ e $165 \%$, respectivamente. Este fato pode ter ocorrido em função da escassez de locais adequados para disposição dos resíduos nos municípios de grande porte (IPEA, 2012). 
Tabela 1 - Quantidade de resíduos sólidos domiciliares e/ou públicos encaminhados para disposição em solo, considerando apenas lixão, aterro controlado e aterro sanitário (t/dia).

\begin{tabular}{lcccccc}
\hline & \multicolumn{2}{c}{ Lixão } & \multicolumn{2}{c}{ Aterro controlado } & \multicolumn{2}{c}{ Aterro sanitário } \\
\cline { 2 - 7 } & 2000 & 2008 & 2000 & 2008 & 2000 & 2008 \\
\hline Brasil & $\mathbf{4 5 . 4 8 4 , 7}$ & $\mathbf{3 7 . 3 6 0 , 8 0}$ & $\mathbf{3 3 . 8 5 4 , 3}$ & $\mathbf{3 6 . 6 7 3 , 2}$ & $\mathbf{4 9 . 6 1 4 , 5}$ & $\mathbf{1 1 0 . 0 4 4 , 4}$ \\
\hline \multicolumn{7}{c}{ Estrato populacional } \\
\hline Munícipios pequenos & $34.533,1$ & $32.504,3$ & $10.405,9$ & $14.067,9$ & $6.878,4$ & $32.420,5$ \\
Munícipios médios & $10.119,6$ & $4.844,5$ & $15.525,5$ & $17.278,3$ & $17.105,8$ & $45.203,4$ \\
Munícipios grandes & 832,0 & 12,0 & $7.922,9$ & $5.327,0$ & $25.630,3$ & $32.420,5$ \\
\hline & \multicolumn{7}{c}{ Macrorregião } \\
\hline Norte & $6.148,5$ & $4.892,5$ & $3.221,8$ & $4.688,2$ & $1.350,2$ & $4.540,6$ \\
Nordeste & $20.579,6$ & $23.461,5$ & $6.113,1$ & $6.819,0$ & $6.714,9$ & $25.246,6$ \\
Sudeste & $11.521,0$ & $3.636,2$ & $15.685,6$ & $16.767,0$ & $32.568,4$ & $61.576,8$ \\
Sul & $4.645,8$ & $1.432,8$ & $4.698,8$ & $3.485,0$ & $5.882,1$ & $15.293,1$ \\
Centro-Oeste & $2.589,8$ & $3.937,8$ & $4.135,0$ & $4.914,0$ & $3.098,9$ & $3.387,3$ \\
\hline
\end{tabular}

Fonte: IPEA (2012)

De acordo com as informações referentes a 2014, constantes no Sistema Nacional de Informações sobre Saneamento - SNIS (2016), da massa total coletada, estimada em 64,4 milhões de toneladas (176.438 t/dia), 52,4\% eram dispostas em aterros sanitários, $13,1 \%$ em aterros controlados, $12,3 \%$ em lixões e 3,9\%, encaminhados para unidades de triagem e de compostagem, restando então uma parcela de 18,3\% sem informação, a qual se refere, sobretudo aos pequenos municípios de até 30 mil habitantes. Salienta-se que as informações do SNIS são uma extrapolação para o número total de municípios, uma vez que somente $67,6 \%$ (com $82,8 \%$ da população brasileira) contribuíram com as informações.

Segundo a Associação Brasileira de Empresas de Limpeza Pública e Resíduos Especiais - ABRELPE (2015), a geração total de RSU no Brasil em 2014 foi de 78.583 .405 toneladas (215.297 t/dia), o que representa um aumento de $2,9 \% \mathrm{em}$ relação a 2013, índice superior à taxa de crescimento populacional no país no período, que foi de 0,9\%. Conforme indicado na Figura 2, a disposição final dos RSU em aterros sanitários no Brasil manteve-se praticamente inalterada entre 2009 e 2014, mesmo tendo entrado em vigor a PNRS em 2010. O mesmo pode ser observado com relação aos lixões. Destarte, conclui-se que as municipalidades não cumpriram a meta de eliminar os lixões e aterros controlados até o final de 2014. 
Figura 2 - Relação entre as destinações finais de RSU no Brasil entre 2007 e 2013.

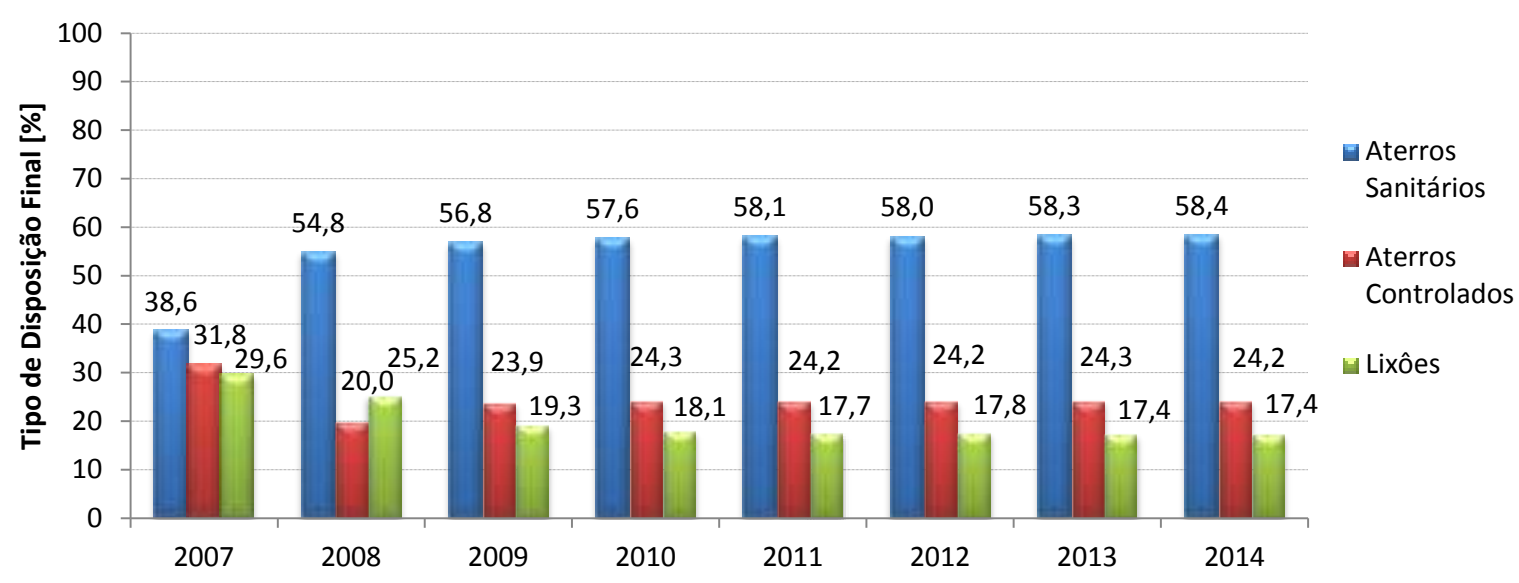

Fonte: Adaptado de ABRELPE (2008 a 2015).

Embora se possa notar uma evolução no panorama geral dos resíduos no Brasil, esta melhora é muito lenta, mesmo com a implementação da PNRS. Diferentemente do que ocorre no Brasil, na Europa, nos Estados Unidos da América (EUA) e em alguns países da Ásia, as mudanças ocorreram mais rapidamente e as legislações são respeitadas, seja por questões culturais ou porque existe um maior rigor quanto à aplicação das penalidades e/ou uma fiscalização mais eficiente.

O que foi preconizado no artigo $9^{\circ}$ da PNRS brasileira já vem sendo adotado há algum tempo nos países desenvolvidos do continente europeu, que estão reduzindo drasticamente a disposição final de resíduos em aterros sanitários, inclusive, em alguns casos até mesmo, tentando eliminar essa possibilidade de disposição, como é o caso da Alemanha e da Suíça - Figura 3 e Figura 4. (EUROSTAT, 2014). 
Figura 3 - Geração per-capita de resíduos e relação entre as destinações na União Europeia entre 1995 e 2012.

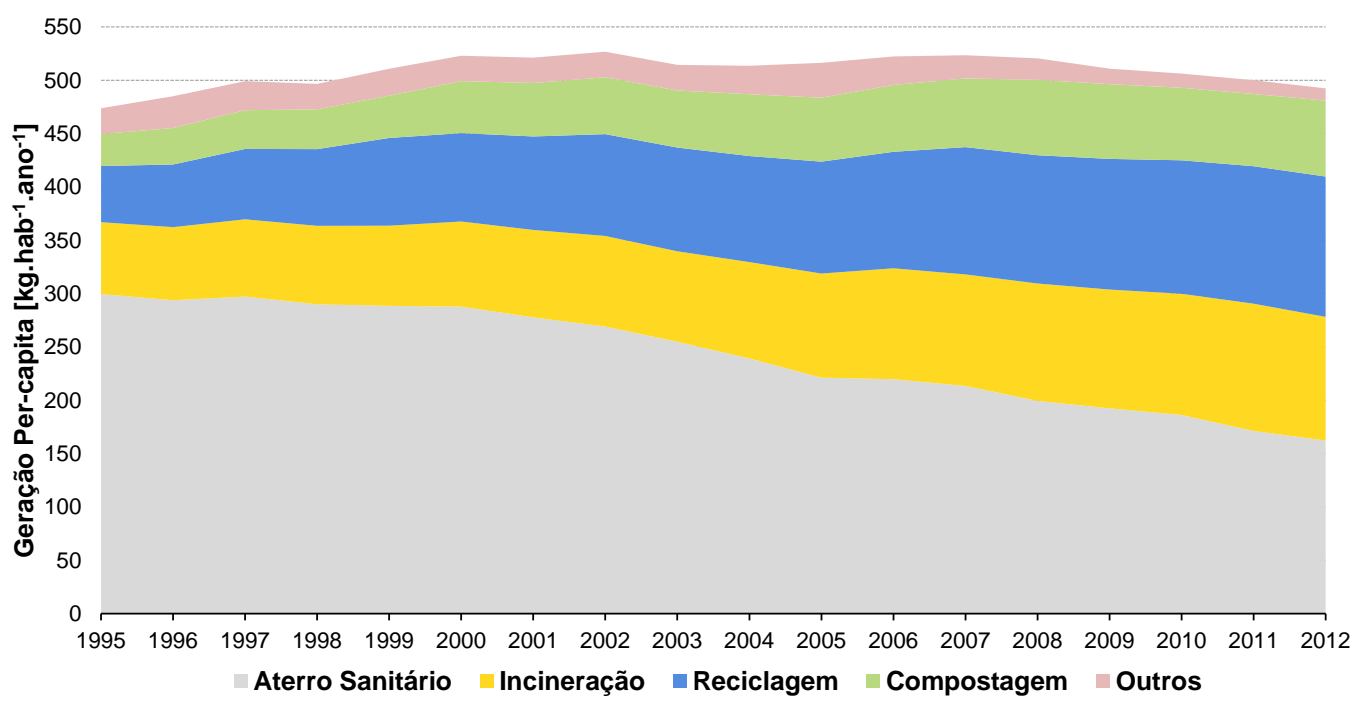

Fonte: Adaptado de Eurostat (2014).

Figura 4 - Relação entre as destinações dos resíduos na União Europeia em 2012.

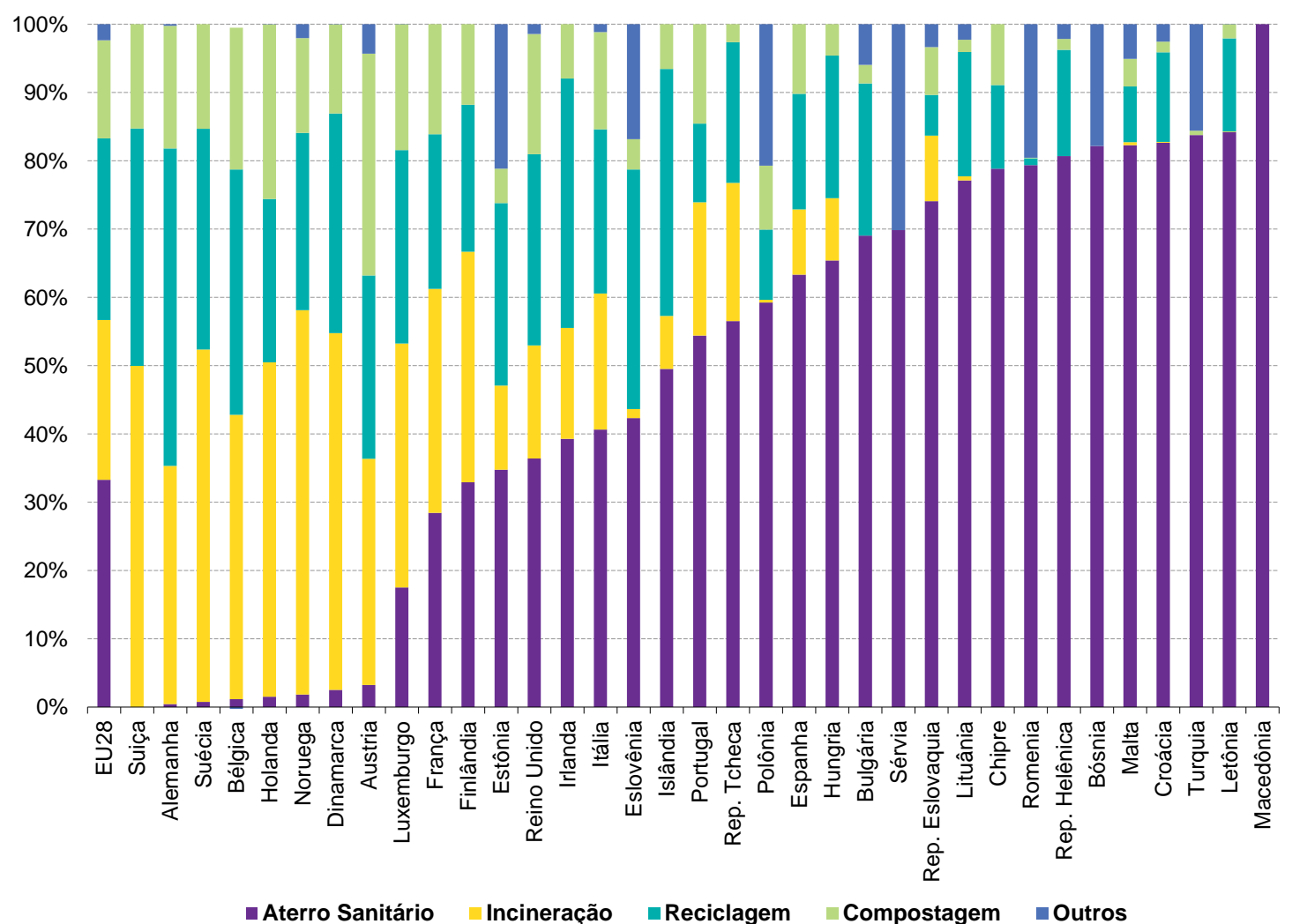

Fonte: Adaptado de Eurostat (2014). 
Embora a digestão anaeróbia sequer apareça nos estudos que quantificam as principais destinações finais de resíduos sólidos (Figura 4), esta tecnologia de tratamento vem ganhando espaço nos últimos anos (DE BAERE e MATTHEEUWS, 2013).

As primeiras instalações de digestão anaeróbia da Europa foram construídas para o tratamento de resíduos sólidos urbanos mistos, ou seja, sem nenhuma separação da matéria orgânica na fonte. Todavia, o rápido aumento da coleta seletiva nos anos 90 provocou a implementação de um grande número de instalações de digestão anaeróbia, embora a tecnologia ainda não estivesse totalmente madura. Segundo De Baere e Mattheeuws (2013), após anos de declínio no número de unidades de compostagem, com o aumento da coleta seletiva, ocorreu também um crescimento nestas, sendo a digestão anaeróbia utilizada nas etapas iniciais de seu processo, visando à substituição das fases mais intensivas da compostagem.

O aumento da capacidade instalada da digestão anaeróbia tem sido constante ao longo do tempo. Não se pode afirmar que ela seja mais barata que a compostagem, no entanto, oferece a oportunidade de produzir energia renovável; utilizar uma área superficial menor e contribuir com a redução de odores desagradáveis quando realizada em unidades fechadas. Na Figura 5, pode ser visualizado o aumento da capacidade instalada de digestão anaeróbia nos países onde a mesma é mais relevante (países com maior capacidade instalada por milhão de habitantes) e na Figura 6 , a capacidade total instalada de cada país. Países como a Suíça, a Holanda e a Alemanha foram os primeiros a adotar a tecnologia, enquanto a França e a Espanha começaram bem mais tarde.

No continente americano, os EUA se destacam, tanto por ser um grande gerador de resíduos como também por ser o país com mais recursos e tecnologias que podem ser aplicadas. Entretanto, ele possui dimensões continentais e uma cultura de consumo diferente do povo europeu, o que leva a uma realidade diferente. 
Figura 5 - Aumento da capacidade instalada de digestão anaeróbia por milhões de habitantes por país.

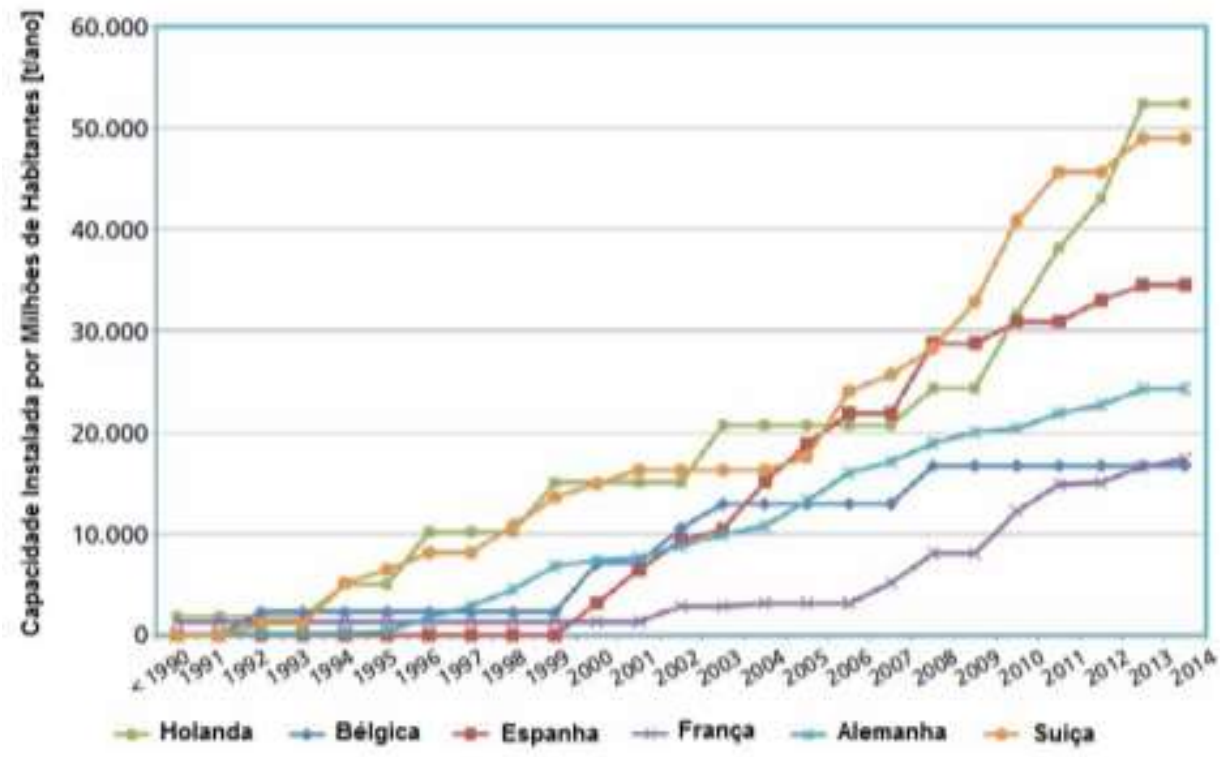

Fonte: De Baere e Mattheeuws (2013).

Figura 6 - Capacidade total instalada por país.

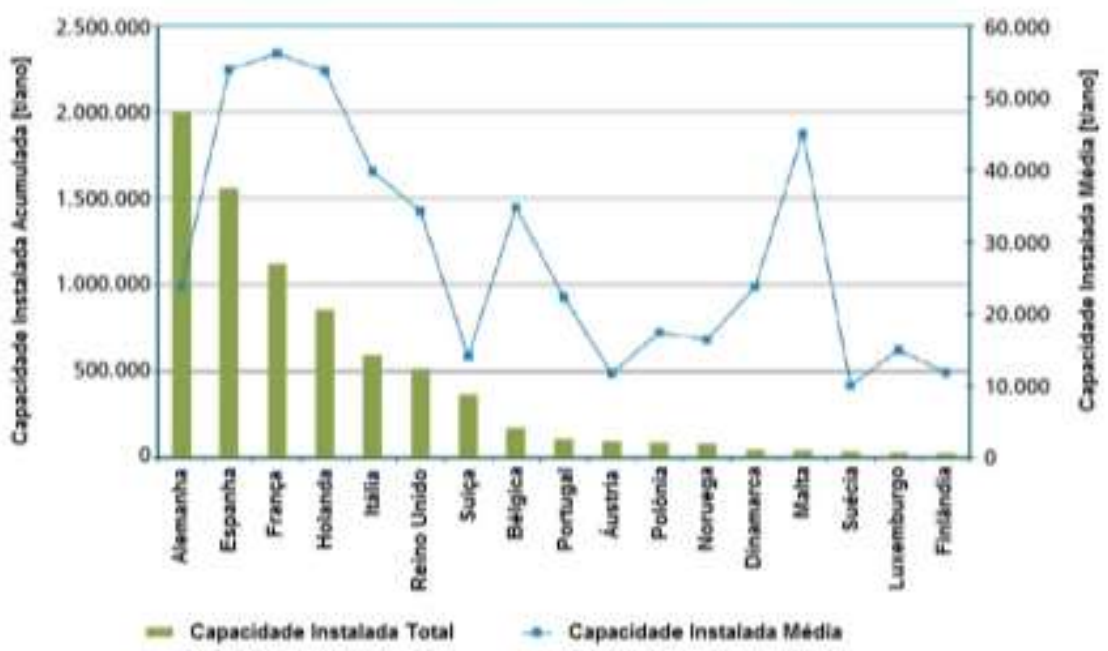

Fonte: De Baere e Mattheeuws (2013).

Observa-se pela Figura 7 que houve uma geração praticamente crescente de resíduos nos EUA desde 1960 até meados de 2008, ano em que esta sofreu um ligeiro declínio, devido à crise econômica do país, e tendeu a se estabilizar entre os anos de 2009 a 2012. A incineração com recuperação energética começou a ser usada a partir de 1980 e houve um incremento da reciclagem a partir de 1990, época em que se constata o início da compostagem de resíduos orgânicos. 
Figura 7 - Destinações dos RSU nos EUA de 1960 a 2012.

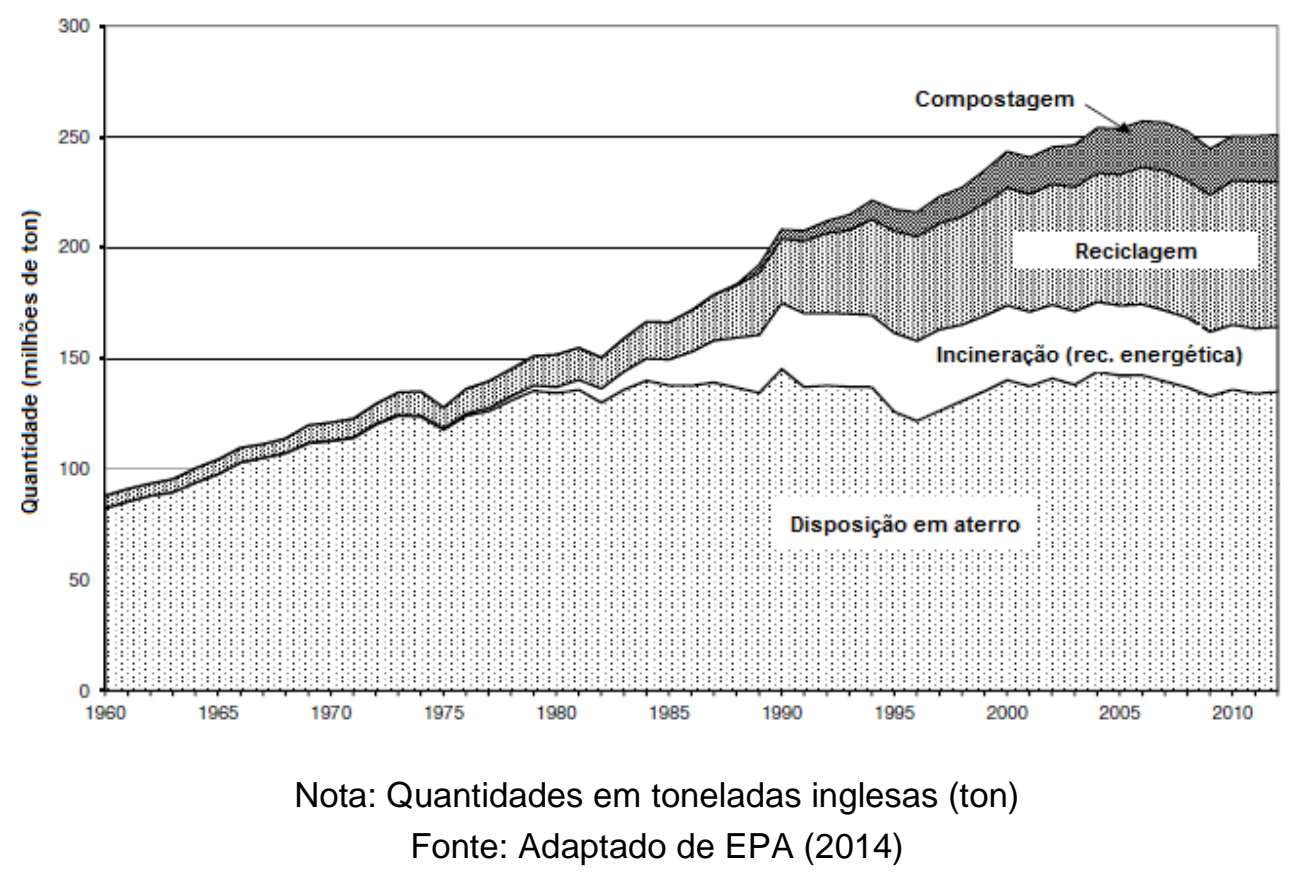

A Tabela 2 mostra as composições percentuais dos resíduos gerados, recuperados e dispostos em aterros nos EUA no ano de 2012 (EPA, 2014). Nota-se que a fração composta por papel e papelão $(27,4 \%)$ possui a mesma ordem de grandeza da fração orgânica putrescível - resíduos de alimentos e jardinagem (28,0\%), o que contrasta com os países em desenvolvimento, cuja fração preponderante é a putrescível, que geralmente supera os 50\% (UNEP, 2011). Observa-se também pela Tabela 2 que a fração dos plásticos é muito pouco aproveitada e a fração de couro, borracha e têxteis é disposta totalmente em aterros.

Nos EUA, onde a disposição em aterros ainda é elevada, tem se optado pela compostagem dos resíduos de jardinagem, uma vez que os alimentos normalmente são triturados e descartados na rede de esgoto. Ressalta-se que os resíduos de jardinagem, devido ao seu baixo peso específico e grandes quantidades geradas, quando dispostos em aterros sanitários reduzem consideravelmente a vida útil dos mesmos. Quanto à digestão anaeróbia nos EUA, a EPA (2014) sequer a cita em seu documento, provavelmente, por ser pouco significativa em âmbito nacional. 
Tabela 2 - Composição percentual dos resíduos gerados, recuperados e dispostos em aterros nos EUA em 2012.

\begin{tabular}{lccc}
\hline COMPONENTE & \multicolumn{3}{c}{ Fração [\%] } \\
\cline { 2 - 4 } & $\begin{array}{c}\text { Coletada } \\
\text { (gerada) }\end{array}$ & $\begin{array}{c}\text { Recuperada } \\
\text { (recicl. }+ \\
\text { compost.) }\end{array}$ & $\begin{array}{c}\text { Disposta } \\
\text { (em aterro) }\end{array}$ \\
\hline Resíduos de alimentos & 14,5 & 2,0 & 21,1 \\
Resíduos de jardinagem & 13,5 & 22,6 & 8,7 \\
Papel e papelão & 27,4 & 51,2 & 14,8 \\
Metais & 8,9 & 8,8 & 9,0 \\
Plásticos & 12,7 & 3,2 & 17,6 \\
Vidros & 4,6 & 3,7 & 5,1 \\
Borracha, couro e têxteis & 8,7 & - & 11,2 \\
Madeira & 6,3 & 2,8 & 8,2 \\
Outros e Rejeitos & 3,4 & 5,7 & 4,3 \\
\hline Massa Total $\left[10^{6}\right.$ t] & 228 & 79 & 146 \\
\hline
\end{tabular}

Nota: Massas convertidas em toneladas métricas (t)

Fonte: Adaptado de EPA (2014).

Com relação ao continente asiático, informações referentes à gestão dos resíduos sólidos são muito difíceis de serem obtidas, pois os estudos encontrados sempre apresentam informações dispersas, incompletas e desatualizadas, com exceção do Japão.

Informações sobre a geração e a destinação dos resíduos sólidos no Japão nos anos fiscais de 2000 a 2013 (MINISTRY OF THE ENVIRONMENT GOVERMENT OF JAPAN, 2015) podem ser visualizadas na Tabela 3. Pode-se notar uma redução praticamente contínua na geração total de resíduos neste período, o que pode ser ainda evidenciado pela queda de $15,4 \%$ na geração per capita. Observa-se, também, um aumento de $17,9 \%$ da massa total de material reciclado e uma redução de $56,8 \%$ da massa de resíduos aterrada neste período, principalmente devido à escassez de áreas para construção de aterros sanitários naquele país. 
Tabela 3 - Informações sobre a gestão dos resíduos sólidos no Japão entre os anos fiscais de 2000 a 2013.

\begin{tabular}{|c|c|c|c|c|c|c|c|c|}
\hline \multirow{2}{*}{ Parâmetro } & \multicolumn{8}{|c|}{ Ano Fiscal } \\
\hline & 2000 & 2002 & 2004 & 2006 & 2008 & 2010 & 2012 & 2013 \\
\hline $\begin{array}{l}\text { Massa total } \\
\text { gerada/coletada }\left[10^{6} \mathrm{t}\right]\end{array}$ & 52,36 & 51,61 & 53,38 & 52,02 & 48,11 & 45,36 & 45,23 & 44,87 \\
\hline $\begin{array}{l}\text { Geração per-capita } \\
\text { [kg/hab.d] }\end{array}$ & 1,132 & 1,111 & 1,146 & 1,115 & 1,033 & 0,976 & 0,964 & 0,958 \\
\hline Massa total reciclada $\left[10^{6} \mathrm{t}\right]$ & 7,86 & 8,64 & 9,40 & 10,21 & 9,78 & 9,45 & 9,26 & 9,27 \\
\hline Disposição final $\left[10^{6} \mathrm{t}\right]$ & 10,51 & 9,03 & 8,09 & 6,80 & 5,53 & 4,84 & 4,65 & 4,54 \\
\hline $\begin{array}{l}\text { Número de instalações de } \\
\text { incineração }\end{array}$ & 1.715 & 1.490 & 1374 & 1280 & 1.269 & 1.221 & 1.189 & 1.172 \\
\hline $\begin{array}{l}\text { Capacidade total de } \\
\text { tratamento [t/dia] }\end{array}$ & 201.557 & 198.874 & 195.952 & 187.823 & 187.303 & 185.372 & 184.426 & 182.683 \\
\hline $\begin{array}{l}\text { Capacidade média por } \\
\text { unidade [t/dia] }\end{array}$ & & 133 & 143 & 147 & 148 & 152 & 155 & 156 \\
\hline $\begin{array}{l}\text { Inst. com aproveitamento } \\
\text { do calor residual }\end{array}$ & 1.111 & 1.035 & 992 & 869 & 849 & 792 & 781 & 778 \\
\hline $\begin{array}{l}\text { Instalações com geração } \\
\text { de energia }\end{array}$ & 233 & 263 & 281 & 291 & 300 & 306 & 318 & 328 \\
\hline $\begin{array}{l}\text { Capacidade de geração } \\
\text { [MW] }\end{array}$ & 1.192 & 1.365 & 1.491 & 1.584 & 1.615 & 1.700 & 1.754 & 1.770 \\
\hline
\end{tabular}

Fonte: Compilado do Web Site Ministry of the Environment Goverment of Japan (2015).

O número absoluto de incineradores tem diminuído em função do tempo $(-31,7$ \%), todavia a capacidade de tratamento não reduziu na mesma proporção $(-9,4 \%)$, mostrando que as unidades antigas estão sendo substituídas por instalações de maior capacidade. Pode-se notar a redução do número de unidades que fazem o aproveitamento direto do calor $(-30,0 \%)$ e o aumento do número daquelas que geram eletricidade $(+40,8 \%)$.

A China é um país que vem sofrendo grandes mudanças nos últimos anos devido ao forte crescimento econômico e industrial, bem como à intensa migração da população do campo para as cidades, o que tem gerado um grande impacto na gestão dos resíduos. Dong (2011) apresenta as quantidades geradas de RSU na China entre 1979 e 2009 (Figura 8a) e as principais destinações no ano de 2009 (Figura $8 b$ ), sendo $79 \%$ dispostos em aterro, $18 \%$ incinerados e $2 \%$ compostados. 
Figura 8 - RSU na China: (a) Quantidades geradas de 1979 a 2009 e (b) Destinações em 2009.

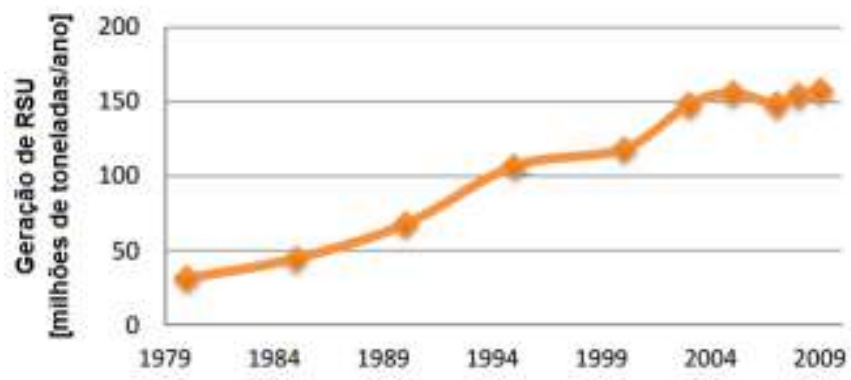

(a)

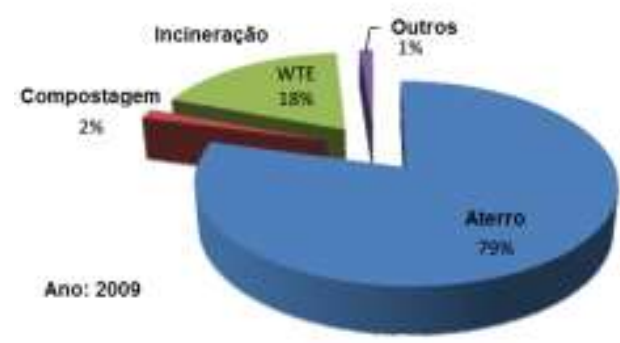

(b)

Fonte: Adaptado de Dong (2011).

A situação social e econômica dos países não afeta somente as quantidades de resíduos geradas, mas também as proporções entre as frações constituintes dos RSU. De acordo com UNEP (2011), quando um país se desenvolve e se torna mais rico, a composição dos seus resíduos torna-se, normalmente, mais variada e complexa. A Figura 9 mostra a variação da composição das frações dos resíduos em países de baixa, média e alta renda e ressalta a proporção elevada da fração orgânica dos RSU nos que possuem um rendimento nacional bruto per capita menor que US\$12.196,00. Nos países de alta renda, os RSU contém uma grande proporção de papel e plásticos, provavelmente, devido ao maior uso de embalagens. A Figura 10 ilustra a geração per capita de resíduos em função da renda per-capita em dólares americanos e mostra uma relação direta entre estas variáveis. Todavia, existem exceções, como o caso do Japão, que apesar de ter renda per capita quase igual à americana, possui geração per capita de RSU aproximadamente igual à metade da americana, como pode ser observado na Figura 11. 
Figura 9 - Proporções entre as frações dos RSU em função das rendas dos países.
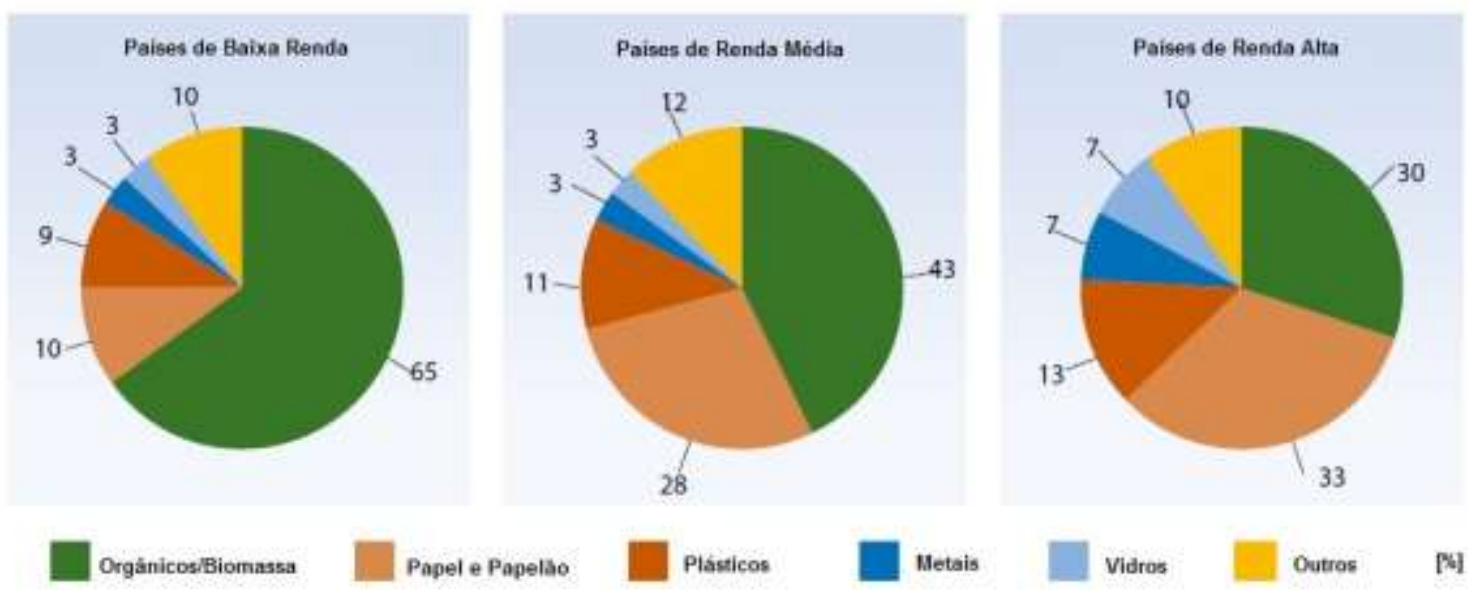

Fonte: Adaptado de UNEP (2011).

Figura 10 - Relação entre a geração de resíduos e a renda per capita anual de alguns países.

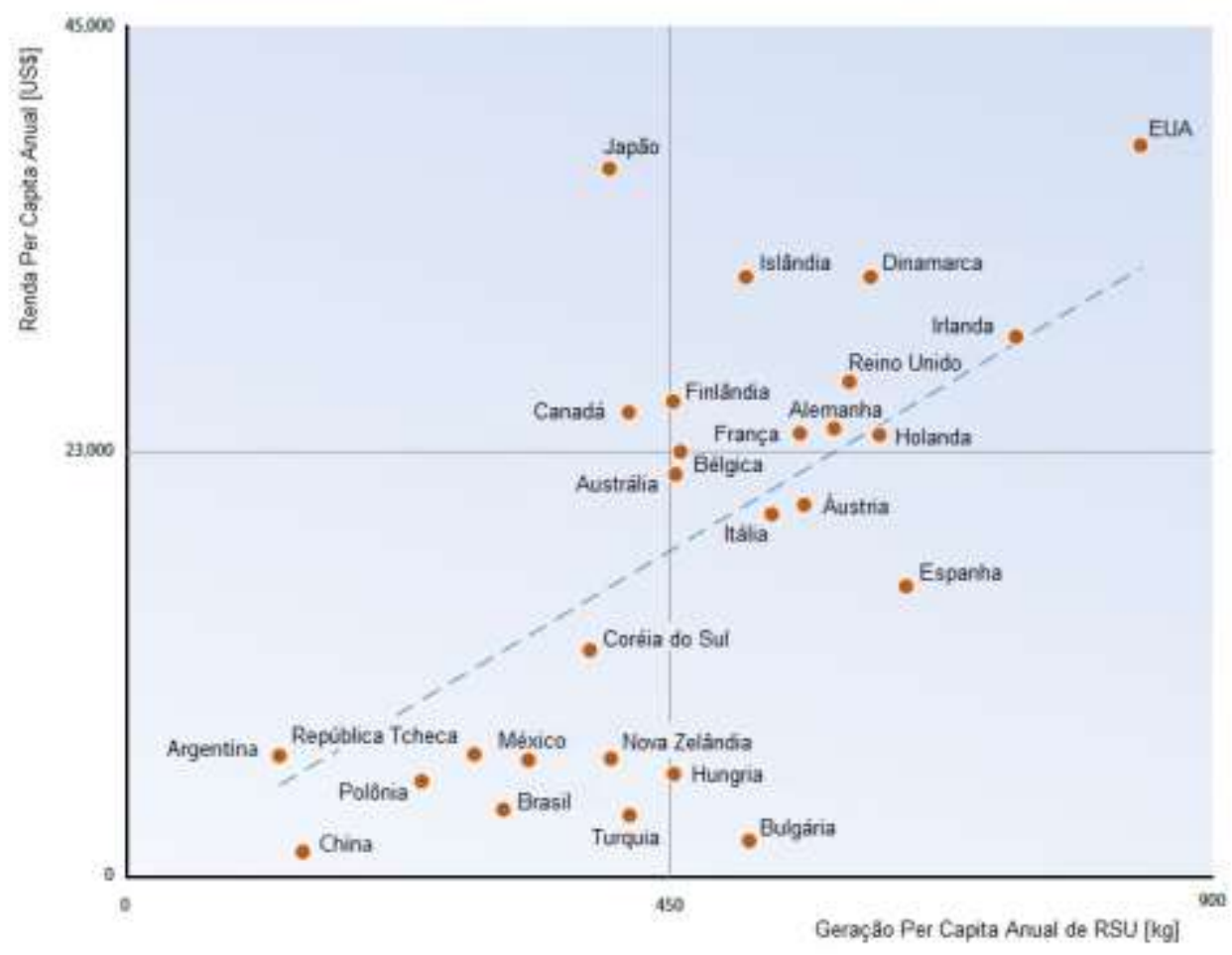

Fonte: Adaptado de UNEP (2011). 
Figura 11 - Geração per capita de resíduos de alguns países membros da OECD em 2011.

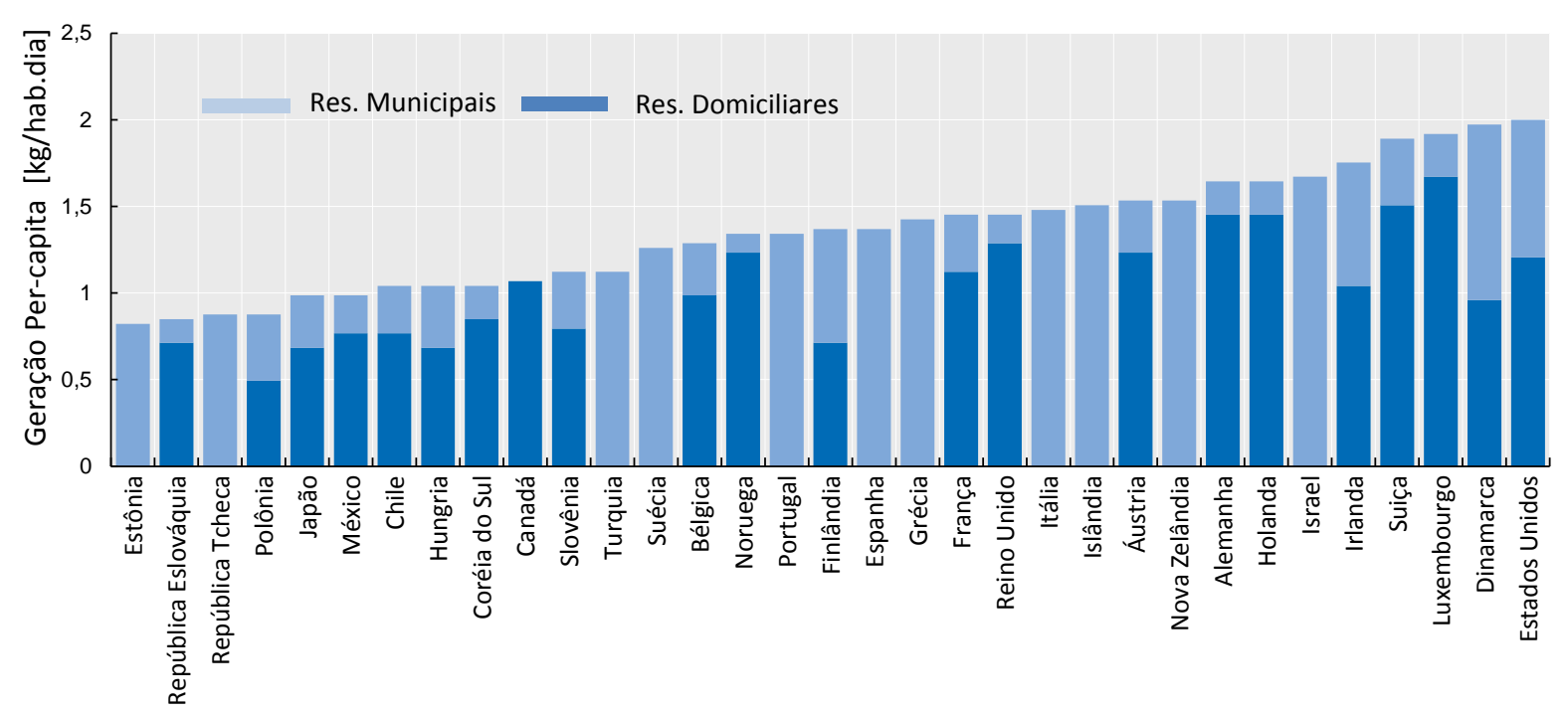

Fonte: Adaptado de OECD Environment Statistics (2013).

A Figura 12 mostra a destinação e a disposição dos resíduos sólidos de alguns países membros da OECD em 2011. Nota-se que, com exceção do Japão, somente países europeus estão eliminando a disposição final de resíduos em aterros sanitários.

Figura 12 - Destinação e disposição dos RS de alguns países membros da OECD em 2011.

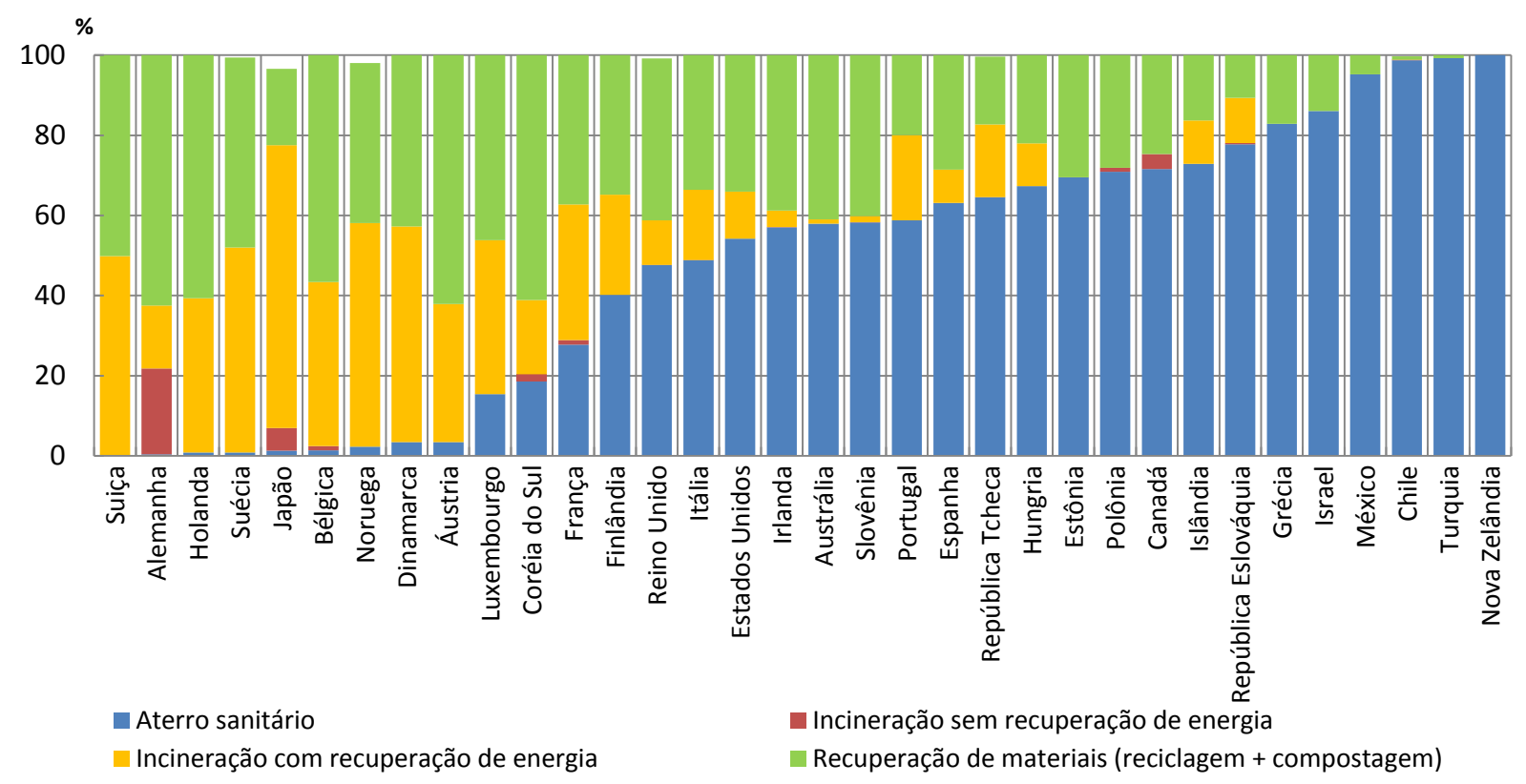

Fonte: Adaptado de OECD Environment Statistics (2013). 


\subsection{Caracterização dos RSU Gerados no Brasil}

A composição dos RSU pode variar principalmente em função dos hábitos culturais, sociais e da situação econômica de cada população, quer seja representada por um bairro, um povoado, um distrito, ou uma grande metrópole. Dessa forma, sua caracterização fornece informações qualitativas e quantitativas, que são essenciais para determinação das tecnologias de tratamento a serem empregadas em cada localidade. A Tabela 4 mostra a composição gravimétrica dos resíduos coletados no Brasil, segundo o diagnóstico dos RSU, realizado pelo IPEA (2012). A tabela foi construída a partir da média simples da composição gravimétrica de 93 municípios brasileiros, pesquisados entre 1995 e 2008.

Tabela 4 - Estimativa da composição gravimétrica dos resíduos sólidos coletados no Brasil.

\begin{tabular}{lc}
\hline \multirow{2}{*}{ COMPONENTE } & Participação Média \\
\cline { 2 - 2 } Matéria Orgânica Putrescível & $\%$ \\
Metal & 51,4 \\
Papel, papelão e tetrapack & 2,9 \\
Plástico & 13,1 \\
Vidro & 13,5 \\
Rejeitos/outros & 2,4 \\
\hline TOTAL & 16,7 \\
\hline
\end{tabular}

Fonte: IPEA (2012).

Na Tabela 5 são mostradas as caracterizações físicas dos RSU de algumas cidades brasileiras. Ressalta-se, pelos valores apresentados, a grande variabilidade entre as frações dos diversos constituintes dos RSU, entre uma cidade e outra. Desta forma, deve-se evitar o uso de valores médios nacionais ou até mesmo regionais em estudos para não se incorrer em erros. Destarte, é importante cada município ter sua própria caracterização, pois é a partir desta que muitas decisões poderão ser tomadas, principalmente quanto à seleção das melhores tecnologias de tratamento, bem como os dimensionamentos de suas unidades.

Com relação à matéria orgânica, fração de interesse neste trabalho, pôde-se observar uma variabilidade relevante, desde $46,45 \%$ até $79,38 \%$, e, dependendo da fração dos recicláveis, as variações são ainda maiores, como por exemplo, para o papel e papelão, que variaram de $2,28 \%$ a $16,74 \%$. Um problema que dificulta a análise e a comparação entre os resultados das caracterizações apresentadas, é 
que cada uma foi feita praticamente em um ano diferente, ou seja, possivelmente em situações econômicas diferentes, o que pode mascarar possíveis tendências, ou levar a falsas correlações.

Tabela 5 - Caracterização dos RSU de algumas cidades brasileiras.

\begin{tabular}{|c|c|c|c|c|c|c|c|c|}
\hline \multirow[b]{2}{*}{ Cidade } & \multirow[b]{2}{*}{$\begin{array}{c}\text { Geração } \\
\text { Per-capita } \\
\text { [kg/hab.d] }\end{array}$} & \multicolumn{6}{|c|}{ Componente [\%] } & \multirow{2}{*}{$\begin{array}{l}\text { População } \\
\text { aproximada } \\
\text { [hab] (ano) }\end{array}$} \\
\hline & & $\begin{array}{l}\text { Matéria } \\
\text { orgânica }\end{array}$ & $\begin{array}{l}\text { Papel e } \\
\text { papelão }\end{array}$ & Plásticos & Metais & Vidros & $\begin{array}{c}\text { Outros } \\
\text { e } \\
\text { rejeitos* }\end{array}$ & \\
\hline Aquidauana-MS ${ }^{(1)}$ & 0,52 & 72,67 & 3,46 & 5,29 & 1,85 & 1,70 & 14,98 & $\begin{array}{l}33.816 \\
(2000)\end{array}$ \\
\hline Araraquara-SP (2) & 0,75 & 54,14 & 6,27 & 17,61 & 1,77 & 1,17 & 6,03 & $\begin{array}{c}206.573 \\
(2012)\end{array}$ \\
\hline Barreiras-BA $^{(3)}$ & ni & 63,8 & 8,9 & 11,3 & 2,0 & 3,8 & 13,7 & $\begin{array}{c}137.428 \\
(2010)\end{array}$ \\
\hline Bela Vista-GO ${ }^{(4)}$ & 0,70 & 52,9 & 19,0 & 18,76 & 3,75 & 1,93 & 3,66 & $\begin{array}{l}13.770 \\
(2005)\end{array}$ \\
\hline Betim-MG ${ }^{(5)}$ & 1,36 & 54,46 & 9,28 & 11,90 & 3,22 & 1,12 & 20,02 & $\begin{array}{c}429.507 \\
(2008)\end{array}$ \\
\hline Blumenau-SC ${ }^{(6)}$ & 0,58 & 46,45 & 10,23 & 13,68 & 4,22 & 3,71 & 23,55 & $\begin{array}{c}261.808 \\
(2002)\end{array}$ \\
\hline Botucatu-SP $^{(7)}$ & 0,48 & 74,11 & 7,61 & 8,41 & 3,86 & 1,99 & 4,02 & $\begin{array}{c}100.826 \\
(1997)\end{array}$ \\
\hline Cáceres-MT ${ }^{(8)}$ & 0,55 & 60,45 & 9,27 & 13,16 & 2,41 & 3,23 & 11,48 & $\begin{array}{l}84.175 \\
(2007)\end{array}$ \\
\hline Caldas Novas-GO ${ }^{(9)}$ & 0,72 & 58,61 & 13,36 & 12,76 & 2,14 & 1,62 & 12,73 & $\begin{array}{l}57.975 \\
(2004)\end{array}$ \\
\hline$\underset{(10)}{\text { Campina Grande-PB }}$ & 0,67 & 75,44 & 4,12 & 7,88 & 1,10 & 1,26 & 10,21 & $\begin{array}{c}355.331 \\
(2005)\end{array}$ \\
\hline Campinas-SP ${ }^{(11)}$ & 0,87 & 56,5 & 16,2 & 16,3 & 1,1 & 1,3 & 8,6 & $\begin{array}{l}1.080 .113 \\
(2010)\end{array}$ \\
\hline Florianópolis-SC ${ }^{(12)}$ & 0,97 & 46,35 & 14,22 & 14,92 & 2,52 & 4,10 & 17,89 & $\begin{array}{c}342.315 \\
(2002)\end{array}$ \\
\hline Hidrolândia-GO ${ }^{(13)}$ & 0,47 & 64,18 & 10,59 & 15,79 & 3,08 & 2,12 & 4,26 & $\begin{array}{l}14.860 \\
(2004)\end{array}$ \\
\hline Jaú-SP ${ }^{(14)}$ & 0,64 & 49,4 & 4,7 & 10,6 & 3,0 & 2,7 & 29,5 & $\begin{array}{c}131.050 \\
(2010)\end{array}$ \\
\hline Marília-SP ${ }^{(15)}$ & 0,79 & 57 & 16 & 13 & 4 & 4 & 6 & $\begin{array}{c}220.000 \\
(2009)\end{array}$ \\
\hline Palmas-TO ${ }^{(16)}$ & 0,90 & 69,1 & 10,2 & 11,4 & 2,2 & 0,5 & 6,8 & $\begin{array}{c}228.332 \\
(2010)\end{array}$ \\
\hline Parintins-AM ${ }^{(17)}$ & 1,56 & 50,97 & 13,85 & 23,94 & 1,79 & ni & 9,42 & $\begin{array}{c}110.411 \\
(2014)\end{array}$ \\
\hline Pato Branco-PR ${ }^{(18)}$ & 0,48 & 49,65 & 16,74 & 13,70 & 1,89 & 1,33 & 16,68 & $\begin{array}{l}67.302 \\
(2005)\end{array}$ \\
\hline Piracicaba-SP ${ }^{(19)}$ & 0,74 & 79,38 & 2,28 & 9,44 & 1,87 & 1,98 & 5,05 & $\begin{array}{c}364.571 \\
(2011)\end{array}$ \\
\hline São Carlos-SP ${ }^{(20)}$ & 0,68 & 59,08 & 6,44 & 10,47 & 1,31 & 1,67 & 21,03 & $\begin{array}{c}210.370 \\
(2006)\end{array}$ \\
\hline
\end{tabular}

OBS: ni = não informado; $\left(^{*}\right)$ Visando-se homogeneizar a tabela este item inclui além dos rejeitos: trapos, couros, borrachas, tretra pak, etc..

Fonte: (1) Leme e Joia (2006); (2) Brunetti Junior (2013); ${ }^{(3)}$ Carvalho et. al (2011); (4) Marques Júnior e Pasqualetto (2005); ${ }^{(5)}$ Betim (2010); (6) Pinheiro e Polz (2002); (7) Oliveira (1997); (8) Alcântara (2010); (9) Andrade e Prado (2004); (10) Oliveira et. al (2005); (11) Campinas (2012); (12)' Comcap (2012); (13) Carvalho (2005); (14) Rezende et al. (2013); (15) Grego e Schoenhals (2009); (16) Coelho et al. (2011); (17) Picanço et al. (2014); ${ }^{(18)}$ Tabalipa e Fiori (2006); ${ }^{(19)}$ Rocha et al. (2011); ${ }^{(20)}$ Frésca (2007). 
A composição dos resíduos também pode variar ao longo do tempo, como resultado das mudanças dos hábitos, do poder aquisitivo da população, das tecnologias, de situações econômicas momentâneas ou duradouras, etc., como pode ser verificado a Figura 13 que ilustra as variações das composições dos resíduos da cidade de São Paulo de 1927 a 2007.

Figura 13 - Frações dos RSU da Cidade de São Paulo entre 1927 e 2007.

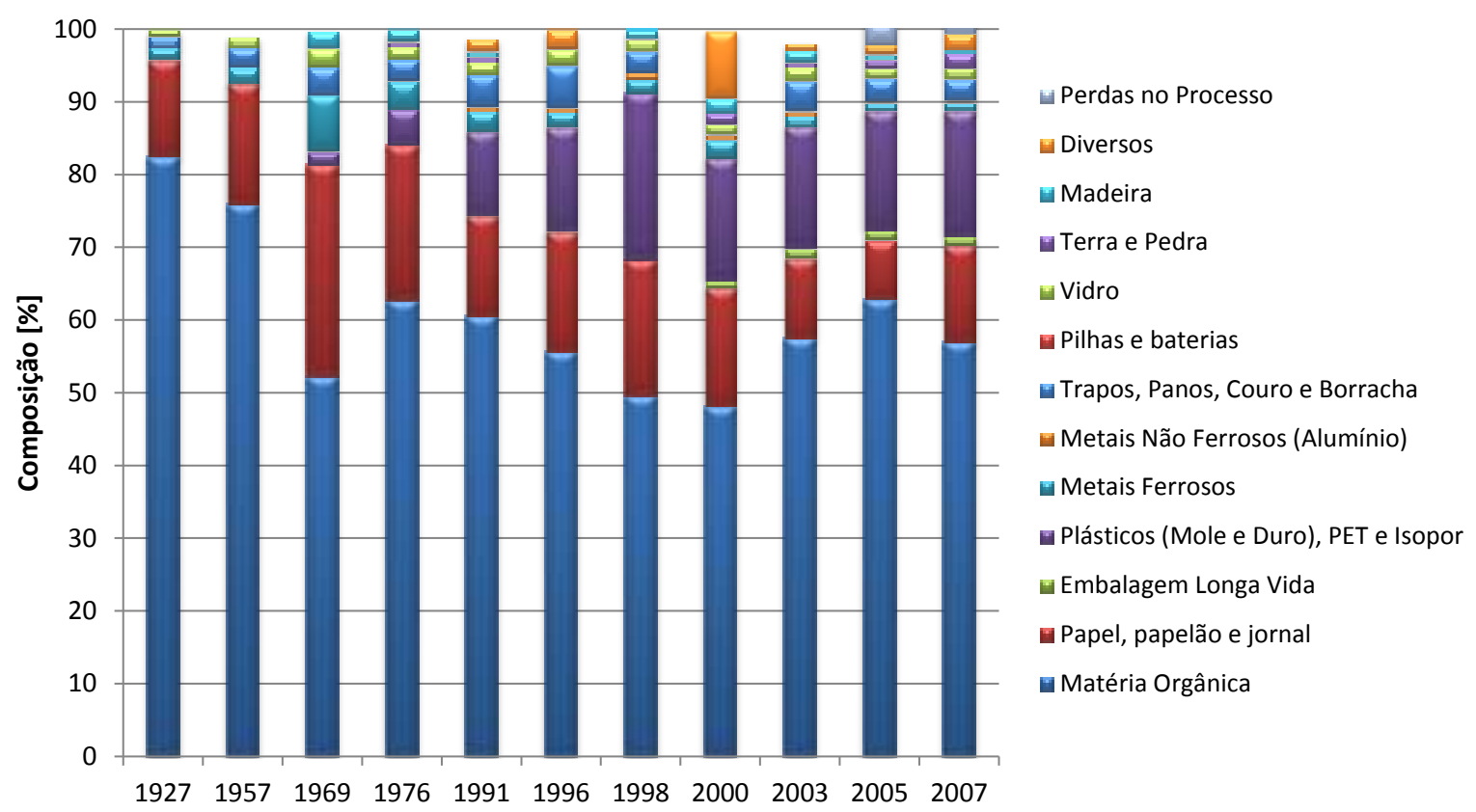

Fonte: Adaptado de Prefeitura Municipal de São Paulo (2007) e - PMSP/ LIMPURB (2003).

\subsubsection{Fração Orgânica dos RSU}

De acordo com Tchobanoglous et al. (1993), a fração orgânica dos RSU é composta por, madeira, papel, papelão, plásticos, têxteis, borracha, couro, restos de alimentos e resíduos de jardinagem, sendo a soma destes dois últimos a fração orgânica putrescível.

Segundo Christensen (2011), as faixas de teor de umidade dos componentes da fração orgânica dos RSU e seus valores típicos são os listados na Tabela 6. 
Tabela 6 - Faixas do teor de umidade dos componentes da fração orgânica dos RSU e seus valores típicos.

\begin{tabular}{lcc}
\hline \multirow{2}{*}{ Material } & \multicolumn{2}{c}{ Teor de Umidade [\%] } \\
\cline { 2 - 3 } & Faixa & Valor Típico \\
\hline Restos de alimentos & $50-80$ & 70 \\
Aparas de grama & $40-80$ & 60 \\
Resíduos de jardinagem & $30-80$ & 60 \\
\hline
\end{tabular}

Fonte: Adaptado de Christensen (2011).

De acordo com Christensen (2011), o conteúdo de matéria orgânica dos resíduos pode ser determinada de várias formas, tais como, sólidos voláteis (SV), carbono orgânico total (COT), Demanda Química de Oxigênio (DQO, em $\mathrm{mgO}_{2} / \mathrm{g}_{\text {resíduo seco). }}$ ) Compostos orgânicos específicos, tais como ácidos graxos voláteis (AGV: ácido acético, ácido propiônico, etc.), proteínas, carboidratos, gorduras, celulose, hemicelulose e lignina também podem ser determinados, ainda que frequentemente estas determinações sejam complexas ou imprecisas.

A matéria orgânica pode ser dividida em compostos facilmente biodegradáveis (carboidratos, lipídios e proteínas) e pouco biodegradáveis (fibras, ácidos húmicos e ácidos fúlvicos). A matéria orgânica biodegradável pode ser dividida em diferentes categorias de substratos. Os carboidratos simples, como a glicose, sacarose ou lactose, aminoácidos ou AGV, não necessitam de qualquer fase de hidrólise para serem biodegradados. Carboidratos complexos, tais como celulose, proteínas e ácidos graxos de cadeia longa, tem que ser hidrolisados em monômeros degradáveis antes da digestão anaeróbia (LESTEUR et al., 2010).

A celulose, a hemicelulose e a lignina são os principias componentes das fibras vegetais (Figura 14), presentes em seus caules, folhas e frutos. As fibras são de difícil digestão por animais não ruminantes, pois a sua estrutura química com uma disposição física muito dispersa criada por lignina e sua ligação cruzada com outros polissacarídeos, impede o acesso de enzimas livres até a celulose e a hemicelulose (KING, 2013).

Na Tabela 7 é ilustrada a composição nutricional média de resíduos orgânicos putrescíveis de diferentes fontes; na Tabela 8 , as concentrações características de alguns componentes vegetais da FORSU, e na Tabela 9, as composições de aparas de jardinagem. 
Figura 14 - Estrutura das fibras vegetais.
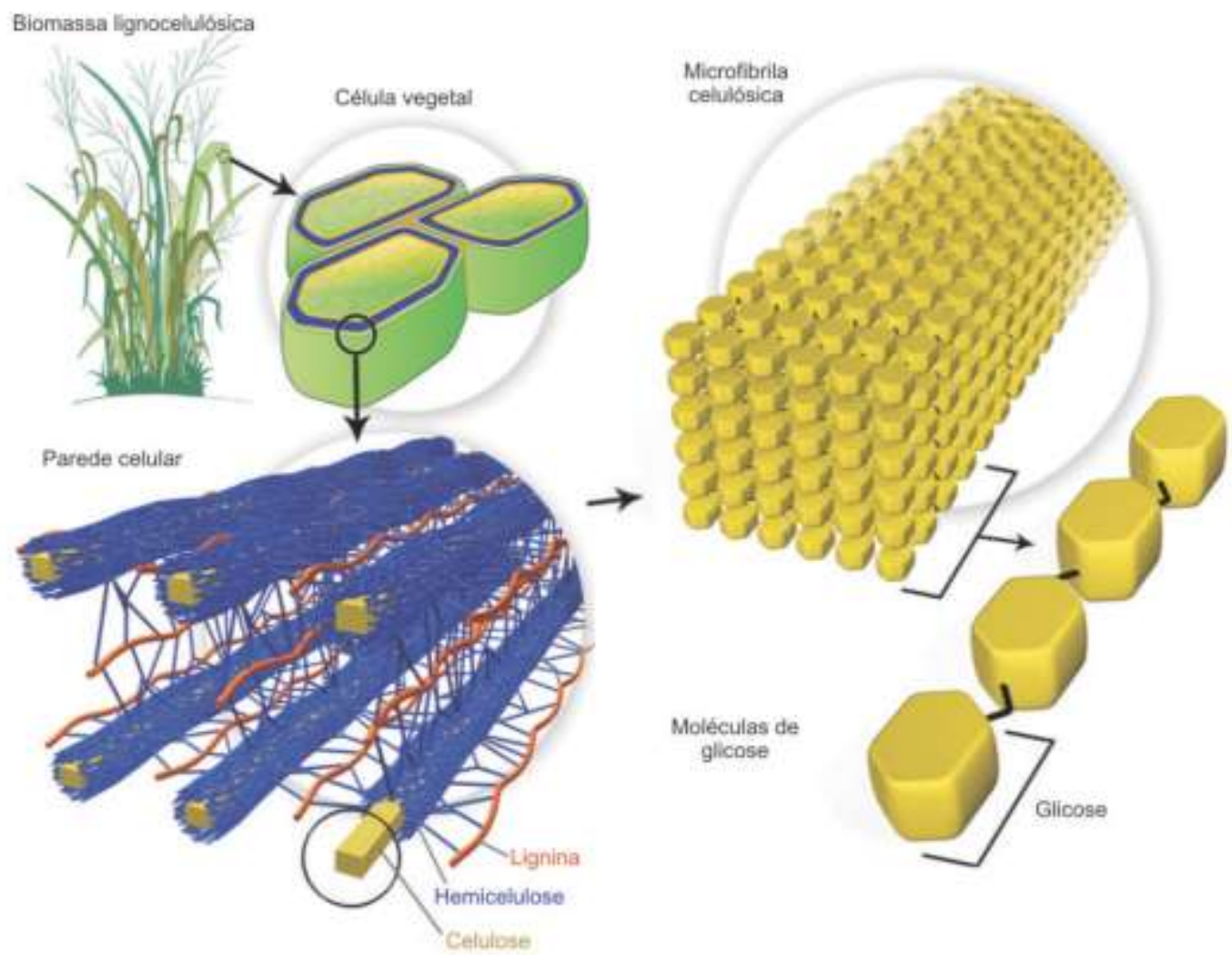

Fonte: Adaptado de Santos (2012).

Segundo Lesteur (2010), a digestão de carboidratos proporciona a menor quantidade de metano por grama de STV $\left(0,415 \mathrm{~L}_{\mathrm{CH} 4} \cdot \mathrm{gSTV}^{-1}\right)$, enquanto que a de lipídios leva à maior quantidade de metano $\left(1,014 \mathrm{~L}_{\mathrm{CH} 4} \cdot \mathrm{gSTV}^{-1}\right)$, desde que suas concentrações sejam baixas; caso contrário, alguns afeitos inibitórios ou adversos podem ocorrer. A digestão de proteínas tem uma produção ligeiramente maior que dos carboidratos $\left(0,496 \mathrm{~L}_{\mathrm{CH} 4} \cdot \mathrm{gSTV}^{-1}\right)$, mas pode levar ao aumento das concentrações de $\mathrm{N}$-amoniacal, que pode ser tóxico em certas concentrações e interfere com os processos biológicos aumentando $\circ \mathrm{pH}$. Hemicelulose e lignina são dificilmente degradados em condições anaeróbias. Digestão de resíduos de cevada produzem cerca de 0,020 $\mathrm{L}_{\mathrm{CH} 4} \cdot \mathrm{gSTV}^{-1}$, aparentemente devido ao seu alto teor de fibra de carboidratos de cerca de 69\% (LESTEUR et al., 2010). Nota-se pelas composições mostradas na Tabela 9, que os resíduos de poda, capina ou jardinagem são de difícil degradação anaeróbia e, portanto, levarão sempre à baixa produção de metano, a não ser que se utilize algum pré-tratamento para se alterar a estrutura física e química das fibras vegetais. 
Tabela 7 - Composição nutricional média de resíduos orgânicos putrescíveis de diferentes fontes (\% com base na massa seca).

\begin{tabular}{lccccc}
\hline Nutriente & $\begin{array}{c}\text { Resíduo de } \\
\text { carne } \\
\text { bovina }\end{array}$ & $\begin{array}{c}\text { Resíduo de } \\
\text { carne de } \\
\text { peixe }\end{array}$ & $\begin{array}{c}\text { Resíduos de } \\
\text { frutas e } \\
\text { vegetais }\end{array}$ & $\begin{array}{c}\text { Resíduos de } \\
\text { restaurantes }\end{array}$ & $\begin{array}{c}\text { Resíduos } \\
\text { domésticos }\end{array}$ \\
\hline Matéria seca & $59,0(12,3)$ & $26,1(2,4)$ & $11,9(1,8)$ & $39,6(7,4)$ & $33,1(10,8)$ \\
Proteína bruta & $24,6(10,3)$ & $57,0(5,3)$ & $11,6(3,6)$ & $27,5(6,4)$ & $16,3(4,8)$ \\
Extrato de éter & $69,9(13,7)$ & $19,1(6,1)$ & $1,5(1,5)$ & $28,8(8,5)$ & $11,3(4,0)$ \\
Fibra bruta & $0,6(0,9)$ & $1,2(1,2)$ & $13,4(4,4)$ & $2,3(1,1)$ & $12,4(7,7)$ \\
Extrato livre de nitrogênio & $0,0(0,0)$ & $0,0(0,0)$ & $65,5(8,8)$ & $26,9(13,2)$ & $41,8(14,0)$ \\
Cinzas (inertes) & $4,9(4,1)$ & $21,8(3,5)$ & $7,9(4,7)$ & $14,4(5,7)$ & $18,2(9,7)$ \\
\hline
\end{tabular}

OBS: Desvio padrão entre parênteses.

Fonte: Adaptado de García et al. (2005).

Tabela 8 - Concentrações características de alguns componentes vegetais da FORSU.

\begin{tabular}{|c|c|c|c|c|c|c|c|c|}
\hline Componente & Unidade & Verduras & Cenoura & Grama & Batata & Banana & Maçã & Laranja \\
\hline NTK & (gN/g $g_{\text {Res.Fresco) }}$ & 0,002 & 0,003 & 0,007 & 0,004 & 0,004 & 0,006 & 0,009 \\
\hline DQO & (gO2/g $\left./ \mathrm{g}_{\text {Res.Fresco }}\right)$ & 0,127 & 0,17 & 0,382 & 0,228 & 0,166 & 0,228 & 0,294 \\
\hline Proteinas & (g/g $\mathrm{g}_{\text {Res.Fresco) }}$ ) & 0,017 & 0,025 & 0,04 & 0,016 & 0,011 & 0,021 & 0,037 \\
\hline Lipidios & (g/g $\left.\mathrm{g}_{\text {Res.Fresco }}\right)$ & 0,007 & 0,006 & 0,018 & 0,006 & 0,005 & 0,004 & 0,008 \\
\hline Açúcares & (g/g $\left.\mathrm{g}_{\text {Res.Fresco }}\right)$ & 0,023 & 0,057 & 0,07 & 0,108 & 0,049 & 0,086 & 0,102 \\
\hline Extrato de Celulose & (g/g $\left.\mathrm{g}_{\text {Res.Fresco }}\right)$ & 0,054 & 0,094 & 0,108 & 0,115 & 0,067 & 0,142 & 0,182 \\
\hline Hemiceluloses & (g/g $\left.\mathrm{g}_{\text {Res.Fresco }}\right)$ & 0,014 & 0,01 & 0,097 & 0,053 & 0,015 & 0,005 & 0,01 \\
\hline Celulose & (g/g $\left.\mathrm{g}_{\text {Res.Fresco }}\right)$ & 0,011 & 0,009 & 0,041 & 0,007 & 0,008 & 0,008 & 0,017 \\
\hline Lignoceluloses & (g/g $\left.\mathrm{g}_{\text {Res.Fresco }}\right)$ & 0,008 & 0,007 & 0,022 & 0,003 & 0,019 & 0,013 & 0,009 \\
\hline Carboidratos & (g/g $\left.\mathrm{g}_{\text {Res.Fresco }}\right)$ & 0,087 & 0,121 & 0,267 & 0,178 & 0,109 & 0,167 & 0,218 \\
\hline PT & (g/g $\left.\mathrm{g}_{\text {Res.Fresco }}\right)$ & -- & 0,00073 & 0,00213 & 0,00072 & 0,00033 & 0,00059 & 0,00102 \\
\hline
\end{tabular}

Fonte: Adaptado de Zaher et al. (2007).

Tabela 9 - Composição química de aparas de jardinagem.

\begin{tabular}{lc}
\hline Componente & Conteúdo em massa ${ }^{*}$ [\%] \\
\hline Celulose & $30,8 \pm 0,5$ \\
Hemicelulose & $15,9 \pm 0,3$ \\
Lignina solúvel em ácido & $0,6 \pm 0,1$ \\
Lignina insolúvel em ácido & $32,3 \pm 0,1$ \\
Extratos & $9,6 \pm 0,2$ \\
Sólidos Voláteis & $98,9 \pm 0,1$ \\
Sólidos Totais & $94,3 \pm 0,1$ \\
\hline
\end{tabular}

* Porcentagens em relação à massa seca, exceto para sólidos totais.

Fonte: Adaptado de Zhao, Zheng e YEBO LI (2014). 
A composição da fração orgânica putrescível dos resíduos domésticos e urbanos pode variar sazonalmente (Tabela 10) e isso pode ter impacto sobre as instalações de processamento. Existem, basicamente, dois tipos de tecnologia concorrentes para o processamento de resíduos putrescíveis, que são a digestão aeróbia (compostagem) e a anaeróbia (biometanização). Ambas dependem da composição dos resíduos, em particular, do conteúdo de carbono e de nutrientes. Variações sazonais da composição destes resíduos podem resultar na necessidade de ajustes por meio de adições para alcançar uma combinação ideal de nutrientes e de carbono (Hanc, 2011). Segundo Kiehl (2004), para compostagem, este balanceamento pode ser obtido misturando-se de forma adequada diferentes tipos de resíduos orgânicos, a fim de se buscar um equilíbrio da relação $\mathrm{C} / \mathrm{N}$ dentro da faixa aceitável, ou adicionar os nutrientes necessários para se obter este equilíbrio.

Tabela 10 - Composição média das frações putrescíveis dos RSU e RD ao longo de um ano.

\begin{tabular}{|c|c|c|c|c|}
\hline \multirow{2}{*}{ Componente } & \multicolumn{2}{|c|}{$\begin{array}{c}\text { Putrescíveis Urbanos }^{(\mathrm{a})} \\
{[\%]}\end{array}$} & \multicolumn{2}{|c|}{$\begin{array}{c}\text { Putrescíveis Domiciliares }^{(\mathbf{b})} \\
{[\%]}\end{array}$} \\
\hline & Média & DP & Média & DP \\
\hline Gramas & 3,9 & 5,6 & 29,0 & 30,4 \\
\hline Plantas & 11,6 & 5,7 & 5,8 & 3,9 \\
\hline Folhas & 1,6 & 1,6 & 27,6 & 30,8 \\
\hline Madeiras & 1,1 & 1,0 & 17,5 & 4,7 \\
\hline Frutas cítricas & 14,0 & 4,3 & 1,5 & 2,3 \\
\hline Frutas não cítricas e vegetais & 44,2 & 7,8 & 5,4 & 2,8 \\
\hline Pães & 3,2 & 1,1 & 0,0 & 0,0 \\
\hline Extratos (cama) & 3,9 & 0,7 & 0,3 & 0,6 \\
\hline Solo & 9,3 & 5,7 & 11,5 & 11,1 \\
\hline Papéis & 2,7 & 0,8 & 0,4 & 0,5 \\
\hline Outros & 3,8 & 0,8 & 0,3 & 0,3 \\
\hline Rejeitos & 0,8 & 0,6 & 0,5 & 0,3 \\
\hline
\end{tabular}

OBS: ${ }^{(a)} 52$ amostragens; ${ }^{(b)} 24$ amostragens; DP = Desvio padrão;

Fonte: Hanc (2011).

Observando-se os valores mostrados na Tabela 10, para as variações dos componentes das frações putrescíveis dos RSU e RSD, notam-se variações percentuais muito grandes dos componentes, obtidas em amostragens realizadas ao longo de um ano, de tal modo que os desvios padrão chegam a possuir a mesma ordem de grandeza dos valores médios e em alguns casos até os superam. Dessa forma, não parece ser viável tentar fazer qualquer controle sobre estes 
componentes; o ideal é que os sistemas de tratamento sejam robustos o suficiente para absorverem tais variações.

\subsection{Lixiviados de Aterros Sanitários}

Um dos grandes problemas da disposição final de resíduos sólidos em aterros sanitários é a geração dos lixiviados, que possuem elevado potencial poluidor e necessitam de tratamento complexo para posterior descarga nos corpos hídricos.

A ABNT (1992) define percolado como o líquido que passou através de um meio poroso e define sumeiro ou chorume como o líquido produzido pela decomposição de substâncias contidas nos resíduos sólidos, que tem como características a cor escura, o mau cheiro e a elevada Demanda Bioquímica de Oxigênio (DBO), quando $\circ$ aterro é novo. Esta mesma norma define lixiviação como o deslocamento ou arraste, por meio líquido, de certas substâncias contidas nos resíduos sólidos urbanos.

Os lixiviados de aterros sanitários apresentam certas particularidades, que além dos tipos de resíduos descartados, dependem também do clima local, da estrutura do aterro, das condições operacionais e da idade do aterro (MILLOT e COURANT, 1997; QASIM e CHIANG, 1994), e as suas características físico-químicas são o resultado de seu processo de formação. Lixiviados são compostos predominantemente por substâncias dissolvidas. A maior parte dos processos de solubilização, lixiviação e precipitação ocorrem dentro do aterro, inicialmente numa condição aeróbia de curta duração, seguida por uma anaeróbia de longa duração. Assim, em geral, os lixiviados têm uma elevada concentração de substâncias orgânicas e inorgânicas dissolvidas, baixa concentração de sólidos em suspensão e, portanto, pouca matéria orgânica remanescente a ser solubilizada (QASIM e CHIANG, 1994; TCHOBANOGLOUS et al., 1993; KJELDSEN et al., 2002). Dentre os diversos parâmetros para sua caracterização, além da $\mathrm{DBO}_{5}$ e $\mathrm{DQO}$, que são normalmente utilizados, destacam-se o Carbono Orgânico Total (COT), Ácidos Voláteis Totais (AVT) e os Sólidos Voláteis.

Análises de lixiviados coletados durante a fase ácida da decomposição mostram altos valores de $\mathrm{DQO}, \mathrm{DBO}_{5}$, Ácidos Voláteis Totais (AVT), nitrogênio orgânico e amoniacal, e baixos valores de $\mathrm{pH}$. Por outro lado, lixiviados coletados durante a 
fase de fermentação metanogênica, apresentam valores de $\mathrm{pH}$, que podem estar na faixa de 6,5 a 8,5, e de $\mathrm{DQO}, \mathrm{DBO}_{5}$, e nutrientes significativamente menores que os da fase ácida, com exceção do nitrogênio amoniacal. $\mathrm{O}$ pH dos lixiviados não depende somente da concentração dos ácidos presentes, mas também da pressão parcial do $\mathrm{CO}_{2}$ contido no gás do aterro, que está em contato com o lixiviado (TCHOBANOGLOUS et al., 1993).

$\mathrm{Na}$ Tabela 11 são ilustrados os resultados de um trabalho realizado por Souto (2009), que fez um levantamento bibliográfico sobre as características dos lixiviados brasileiros e também os resultados de Andreotolla e Cannas (1992), que reuniram informações sobre mais de 70 aterros sanitários localizados na Europa e Estados Unidos.

Tabela 11 - Faixas de concentração das principais variáveis de caracterização de lixiviados de aterros sanitários brasileiros e americanos e europeus.

\begin{tabular}{|c|c|c|c|c|}
\hline \multirow[t]{2}{*}{ Variável } & \multirow[t]{2}{*}{ Unidade } & \multicolumn{2}{|c|}{$\begin{array}{l}\text { Lixiv. Brasileiros } \\
\text { Souto (2009) }\end{array}$} & \multirow{2}{*}{$\begin{array}{c}\text { Americanos e Europeus } \\
\text { Andreotolla e Cannas (1.992) } \\
\text { Fases Acida e Matanogênica }\end{array}$} \\
\hline & & Fase Ácida & Fase Metanog. & \\
\hline $\mathrm{pH}$ & - & $4,4-8,4$ & $5,9-9,2$ & $5,3-8,5$ \\
\hline Alcalinidade & $\mathrm{mg} \mathrm{CaCO} / \mathrm{L}$ & $170-32.000$ & $125-20.200$ & $300-11.500$ \\
\hline Turbidez & UNT & $100-540$ & $0,02-620$ & - \\
\hline Condutividade & $\mu \mathrm{S} / \mathrm{cm}$ & $230-45.000$ & $100-45.000$ & - \\
\hline DQO & $\mathrm{mg} \mathrm{O}_{2} / \mathrm{L}$ & $90-100.000$ & $20-35.000$ & $150-100.000$ \\
\hline $\mathrm{DBO}_{5}$ & $\mathrm{mg} \mathrm{O}_{2} / \mathrm{L}$ & $1-55.000$ & $3-17.200$ & $100-90.000$ \\
\hline $\mathrm{NH}_{4}^{+}$ & $\mathrm{mg} \mathrm{N} / \mathrm{L}$ & $0,07-2.000$ & $0,03-3.000$ & $1-1.500$ \\
\hline NTK & $\mathrm{mg} \mathrm{N} / \mathrm{L}$ & $1,7-3.000$ & $0,6-5.000$ & $50-5.000$ \\
\hline $\mathrm{NO}_{3}^{--}$ & $\mathrm{mg} \mathrm{N} / \mathrm{L}$ & $N D-45$ & ND - 270 & $0,1-50$ \\
\hline$P_{\text {tot }}$ & $\mathrm{mg} P / L$ & $N D-260$ & $N D-80$ & $0,1-30$ \\
\hline $\mathrm{PO}_{4}$ & $\mathrm{mg} / \mathrm{L}$ & - & - & $0,3-25$ \\
\hline $\mathrm{Ca}$ & $\mathrm{mg} / \mathrm{L}$ & - & - & $10-2.500$ \\
\hline $\mathrm{Mg}$ & $\mathrm{mg} / \mathrm{L}$ & - & - & $50-1.150$ \\
\hline $\mathrm{Na}$ & $\mathrm{mg} / \mathrm{L}$ & - & - & $50-4.000$ \\
\hline $\mathrm{K}$ & $\mathrm{mg} / \mathrm{L}$ & - & - & $10-2.500$ \\
\hline $\mathrm{SO}_{4}$ & $\mathrm{mg} / \mathrm{L}$ & - & - & $10-1.200$ \\
\hline $\mathrm{Cl}^{-}$ & $\mathrm{mg} / \mathrm{L}$ & $275-4.700$ & $20-6.900$ & $30-4.000$ \\
\hline Fe Total & $\mathrm{mg} / \mathrm{L}$ & ND - 1.400 & $0,01-720$ & $0,4-2.200$ \\
\hline Zn Total & $\mathrm{mg} / \mathrm{L}$ & ND - 27 & ND - 35 & $0,05-170$ \\
\hline Mn total & $\mathrm{mg} / \mathrm{L}$ & ND - 115 & ND - 30 & $0,4-50$ \\
\hline Cd Total & $\mathrm{mg} / \mathrm{L}$ & $N D-0,1$ & $N D-0,6$ & $0,5-140$ \\
\hline Ni Total & $\mathrm{mg} / \mathrm{L}$ & $N D-6,5$ & $N D-1,4$ & $20-2.050$ \\
\hline Pb Total & $\mathrm{mg} / \mathrm{L}$ & $N D-1,5$ & $N D-6,7$ & $8-1.020$ \\
\hline Cr Total & $\mathrm{mg} / \mathrm{L}$ & $N D-1,2$ & $N D-1,0$ & $30-1.600$ \\
\hline Cu Total & $\mathrm{mg} / \mathrm{L}$ & $N D-0,8$ & $N D-2,9$ & $4-1.400$ \\
\hline ST & $\mathrm{mg} / \mathrm{L}$ & $400-45.000$ & $200-29.000$ & - \\
\hline STV & $\mathrm{mg} / \mathrm{L}$ & $78-26.700$ & $75-20.000$ & - \\
\hline STF & $\mathrm{mg} / \mathrm{L}$ & $40-28.400$ & $100-17.000$ & - \\
\hline SST & $\mathrm{mg} / \mathrm{L}$ & $10-7.000$ & $7-12.400$ & - \\
\hline
\end{tabular}

OBS: ND = Não detectado (limites de detecção não informados pelo autor).

Fonte: Adaptado de Souto (2009); Andreotolla e Cannas (1.992). 
Nota-se que tanto para o caso dos aterros brasileiros, quanto para os americanos e europeus, todos os parâmetros possuem uma faixa de variação muito grande e as concentrações de nitrogênio amoniacal e alcalinidade total são muito elevadas.

Como resultado da variabilidade das características dos lixiviados, o projeto de sistemas de tratamento desses líquidos torna-se bastante complexo (TCHOBANOGLOUS et al., 1993). Os processos aplicáveis ao tratamento de lixiviados são os biológicos; os físico-químicos ou a combinação destes (QASIM e CHIANG, 1994). Sistemas anaeróbios e aeróbios têm sido extensivamente pesquisados para remover matéria orgânica e nitrogênio amoniacal (KULIKOWSKA, 2012). No entanto, eles precisam de uma fonte externa de carbono para a desnitrificação, quando o lixiviado é proveniente de um aterro na fase metanogênica. Por esta razão, recentemente, processos como Anammox e desnitrificação endógena têm sido desenvolvidos com resultados promissores, indicando que a associação de tratamento anaeróbio-aeróbio é possível sem uma fonte extra de carbono (KUENEN, 2008; VAN DER STAR et al., 2007; ANFRUNS et al., 2013; WANG et al., 2013; ZHU et al., 2013).

\subsection{Tratamento da Fração Orgânica Putrescível dos RSU}

A Tabela 12, elaborada pelo IPEA (2012) para o ano de 2008, mostra uma estimativa percentual da matéria orgânica tratada em relação ao total coletado, utilizando como referência a composição gravimétrica média (Tabela 4) e a massa total coletada de resíduos no Brasil para aquele ano. Do total de 94.309,5 t/dia de resíduos orgânicos putrescíveis, apenas $1,6 \%$ são destinados para unidades de compostagem, sendo o restante encaminhado para disposições finais, destacandose lixões, aterros controlados e aterros sanitários. 
Tabela 12 - Estimativa percentual de matéria orgânica tratada em relação ao total coletado.

\begin{tabular}{|c|c|c|c|}
\hline \multirow[t]{2}{*}{ Unidade de análise } & $\begin{array}{l}\text { Qtde encaminhada para } \\
\text { unid. compostagem }\end{array}$ & $\begin{array}{c}\text { Estimativa qtde de } \\
\text { matéria orgânica } \\
\text { coletada }^{1}\end{array}$ & $\begin{array}{c}\text { Percentual de } \\
\text { tratamento em função } \\
\text { da qtde coletada }\end{array}$ \\
\hline & {$[\mathrm{t} / \mathrm{d}]$} & {$[\mathrm{t} / \mathrm{d}]$} & [\%] \\
\hline Brasil & $1.519,5$ & $94.309,1$ & 1,6 \\
\hline \multicolumn{4}{|c|}{ Estrato populacional } \\
\hline Munícipios pequenos & 497,2 & $40.797,3$ & 1,2 \\
\hline Munícipios médios & 495,0 & $32.250,1$ & 1,5 \\
\hline Munícipios grandes & 527,7 & $21.262,1$ & 2,5 \\
\hline \multicolumn{4}{|c|}{ Macrorregião } \\
\hline Norte & 18,4 & $7.523,5$ & 0,2 \\
\hline Nordeste & 13,0 & $24.262,6$ & 0,1 \\
\hline Sudeste & 684,6 & $35.044,1$ & 1,9 \\
\hline Sul & 475,3 & $19.193,7$ & 2,5 \\
\hline Centro-Oeste & 328,2 & $8.285,2$ & 3,9 \\
\hline
\end{tabular}

(1) Quantidade estimada equivale à quantidade total coletada multiplicando-se pela porcentagem da composição gravimétrica.

Fonte: IPEA (2012).

Destarte, há muito a ser feito no Brasil com relação ao tratamento da matéria orgânica putrescível. Na sequência, são descritas algumas alternativas para 0 tratamento desta fração componente dos RSU.

\subsubsection{Tratamento Térmico}

Embora o tratamento térmico da fração orgânica dos resíduos sólidos normalmente não seja a melhor opção, em algumas situações, pode ser uma das poucas alternativas possíveis, principalmente em locais com extrema falta de espaço físico para instalação das unidades de tratamento.

Dentre as tecnologias de tratamento térmico, a incineração dos resíduos com recuperação energética é a que se destaca em grande escala, principalmente em alguns países europeus, como pode ser observado na Figura 4. Todavia, a reciclagem e outras formas de tratamento têm prioridade em relação à incineração.

Segundo Williams (2005), uma das principais vantagens da incineração dos resíduos é a sua redução a cinzas, que são biologicamente estéreis e que apresentam cerca de $10 \%$ do volume, ou $33 \%$ do peso inicial dos resíduos. Por outro lado, a principal desvantagem é o alto investimento inicial e o retorno demorado. 
São muito importantes as propriedades combustíveis do resíduo, ou seja, as proporções entre material combustível, umidade e materiais inertes e também a análise elementar, que pode ser utilizada para avaliar como a queima dos resíduos no incinerador pode afetar as emissões gasosas. O teor de umidade é de extrema importância, uma vez que restringe a ignição e reduz o poder calorífico do resíduo. O teor de inertes destaca-se também, uma vez que uma alta percentagem destes irá diminuir o poder calorífico dos resíduos e formarão as cinzas, que terão de ser removidas e descartadas depois da combustão (WILLIAMS, 2005).

De acordo com Rimaitytè et al. (2010), o poder calorífico dos resíduos não deve ser inferior a $6.500 \mathrm{~kJ}^{\mathrm{kg}}{ }^{-1}$, pois abaixo deste valor há necessidade de adição de combustível para manter a eficiência da incineração.

A composição dos resíduos pode ser representada num diagrama ternário, que apresenta as composições aceitáveis de cada fração (inerte, umidade, voláteis) como ilustrado na Figura 15. A área sombreada representa a composição típica dos resíduos sólidos urbanos, que pode sustentar a combustão sem a necessidade de combustível auxiliar. A área abrange o poder calorífico mínimo aceitável e o teor máximo permitido de umidade.

Figura 15 - Diagrama ternário: Proporção percentual de Voláteis (v) $x$ Inertes (I) x Umidade (U) aceitáveis para incineração

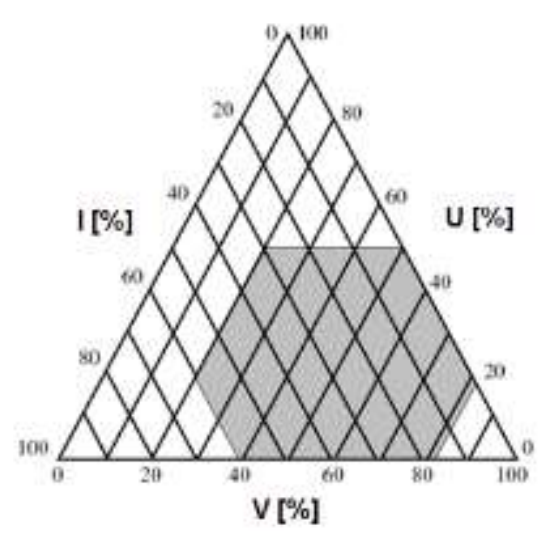

Fonte: Adaptado de Williams (2005)

Gunaseelan (1997) relata que frações orgânicas (putrescíveis) dos resíduos sólidos, compostas por restos de frutas e vegetais, possuem umidade superior a $80 \%$ e teor 
de sólidos voláteis superior a 95\% em relação aos totais. Segundo Mata-Alvarez, Macé e Llabrés (2000), a fração orgânica biodegradável dos RSU apresenta entre 85 e 90\% de umidade. Observando-se a Figura 15, pode-se notar que caso se opte em fazer a incineração da matéria orgânica putrescível dos RSU, esta não se sustentará sem combustível auxiliar. Além desta possível inviabilidade, do ponto de vista energético, a incineração tem ainda como desvantagem em relação à compostagem e à digestão anaeróbia, a perda de nutrientes (para atmosfera ou para as cinzas), que não poderão ser efetivamente reciclados na agricultura.

\subsubsection{Compostagem}

Em termos conceituais, a compostagem pode ser definida como um processo controlado de decomposição aeróbia e exotérmica da matéria orgânica biodegradável por meio da ação de micro-organismos autóctones, com liberação de gás carbônico e vapor de água e tendo como produto final um condicionador de solo (BIDONE; POVINELLI, 1999; DE BERTOLDI et al, 1983; KIEHL, 2012; MASSUKADO, 2008; NBR 13591, 1996; SENESI, 1989). Durante o processo, alguns componentes são utilizados pelos próprios micro-organismos para formação de seus tecidos, outros são volatilizados e outros ainda são transformados biologicamente em uma substância escura, uniforme, com consistência pastosa, rica em partículas coloidais, com propriedades físicas, químicas e biológicas inteiramente diferentes da matéria-prima original. A esta substância dá-se o nome de composto humificado ou simplesmente composto.

Dentre as principais vantagens da compostagem, pode-se citar a reciclagem da matéria orgânica e dos nutrientes; a necessidade de mão de obra pouco especializada; custos menores que os da incineração, tanto na implantação quanto na operação da usina, bem como a produção de um condicionador de solos apresentando de 40 a 70\% de matéria orgânica.

Os micro-organismos que participam mais ativamente do processo são os aeróbios e os facultativos (bactérias, fungos e actinomicetos), que predominam nas faixas de temperatura de 20 a $45{ }^{\circ} \mathrm{C}$ (mesófilos) e de 45 a $65{ }^{\circ} \mathrm{C}$ (termófilos). Esses microorganismos liberam energia na forma de calor, implicando no aquecimento natural das leiras ou pilhas de compostagem. 
A Figura 16 ilustra, esquematicamente, as quatro fases da estabilização da matéria orgânica pela compostagem: a fase 1, onde ocorre a elevação de temperatura até o limite admitido como ótimo (55 e $65^{\circ} \mathrm{C}$ ); a fase 2, de degradação ativa do material orgânico; a fase 3, em que se inicia o resfriamento natural do material; e a fase 4, de maturação ou cura do material compostado, com formação de ácidos húmicos.

A compostagem é afetada por fatores biológicos (micro-organismos), físicos (umidade, temperatura, tamanho das partículas, dimensão e formato das leiras) e químicos (oxigenação, relação $\mathrm{C} / \mathrm{N}$ e pH).

\section{Figura 16 - Fases da estabilização da matéria orgânica na compostagem}

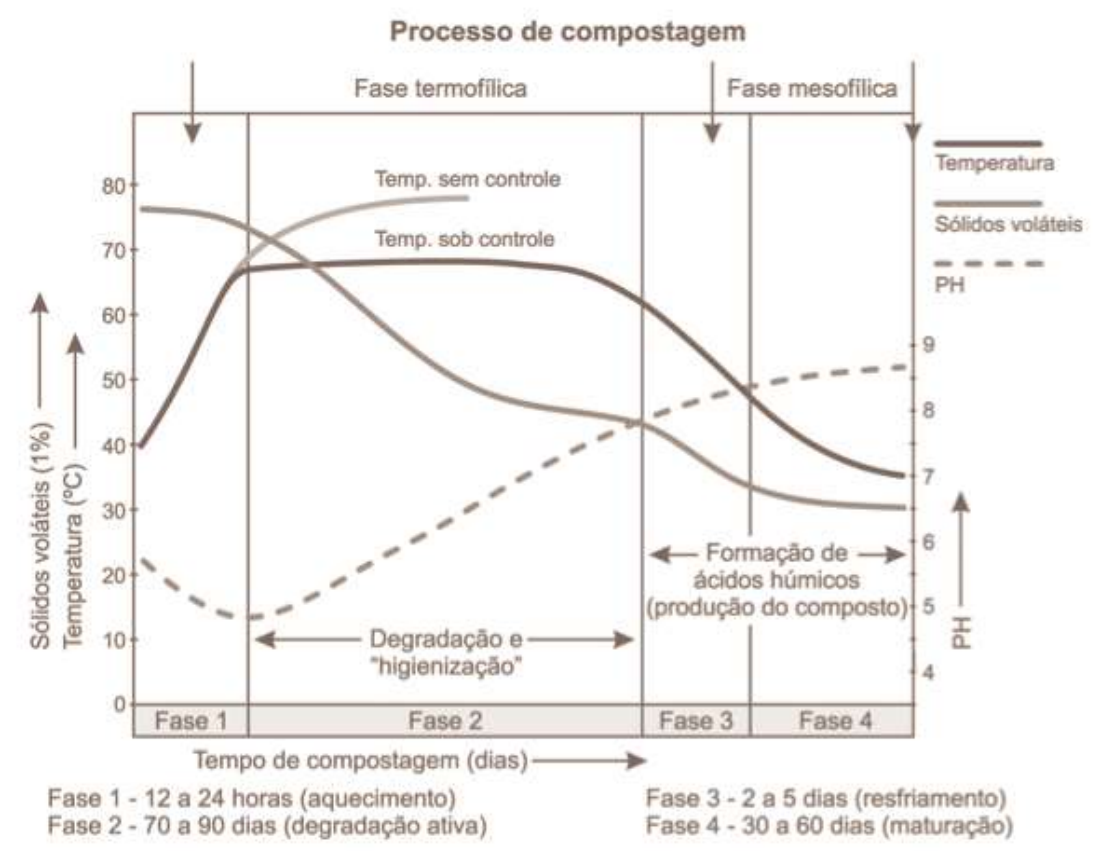

Fonte: FDR (2014)

Adicionalmente, a vermicompostagem é um tipo de compostagem na qual se utilizam minhocas para digerir a matéria orgânica, provocando sua degradação, melhorando o arejamento e a drenagem do material em fase de maturação. Normalmente, ela ocorre em 2 estágios, sendo que no primeiro a matéria orgânica é compostada de acordo com os padrões normais até atingir sua estabilização, a redução de patógenos e temperatura ambiente, e no segundo, o material é transferido para leitos rasos (evitando-se assim o aquecimento elevado e a compactação), onde é realizada a inoculação das minhocas e após 45 a 90 dias, 
obtém-se o vermicomposto, com aumento na disponibilização de macro e micronutrientes.

\subsubsection{Digestão Anaeróbia}

Segundo Chernicharo (1997), a digestão anaeróbia ou biometanização pode ser comparada a um ecossistema onde diversos grupos de micro-organismos trabalham interativamente na conversão da matéria orgânica complexa em metano, gás carbônico, água, gás sulfídrico e nitrogênio amoniacal, além de novas células bacterianas. Os micro-organismos que participam do processo de decomposição anaeróbia podem ser divididos em três importantes grupos:

- O primeiro é composto de bactérias fermentativas, que transformam, por hidrólise, os polímeros em monômeros, e estes em acetato, hidrogênio, dióxido de carbono, ácidos orgânicos de cadeia curta, aminoácidos e outros produtos;

- O segundo grupo é formado pelas bactérias acetogênicas, que convertem os produtos gerados pelo primeiro grupo (aminoácidos, açúcares, ácidos orgânicos e álcoois) em acetato, hidrogênio e dióxido de carbono;

- Os produtos finais do segundo grupo são os substratos essenciais para o terceiro, que por sua vez, constitui-se de dois diferentes grupos de árqueas metanogênicas. Um grupo usa o acetato, transformando-o em metano e dióxido de carbono, enquanto o outro produz metano através da redução de dióxido de carbono.

As fases da digestão anaeróbia, bem como os micro-organismos envolvidos em cada etapa do processo, estão sintetizadas na Figura 17. Cada uma dessas fases é descrita, a partir do texto extraído de Chernicharo (1997), nos itens subsequentes. 
Figura 17: Sequências metabólicas da digestão anaeróbia (com redução de sulfato [---]).

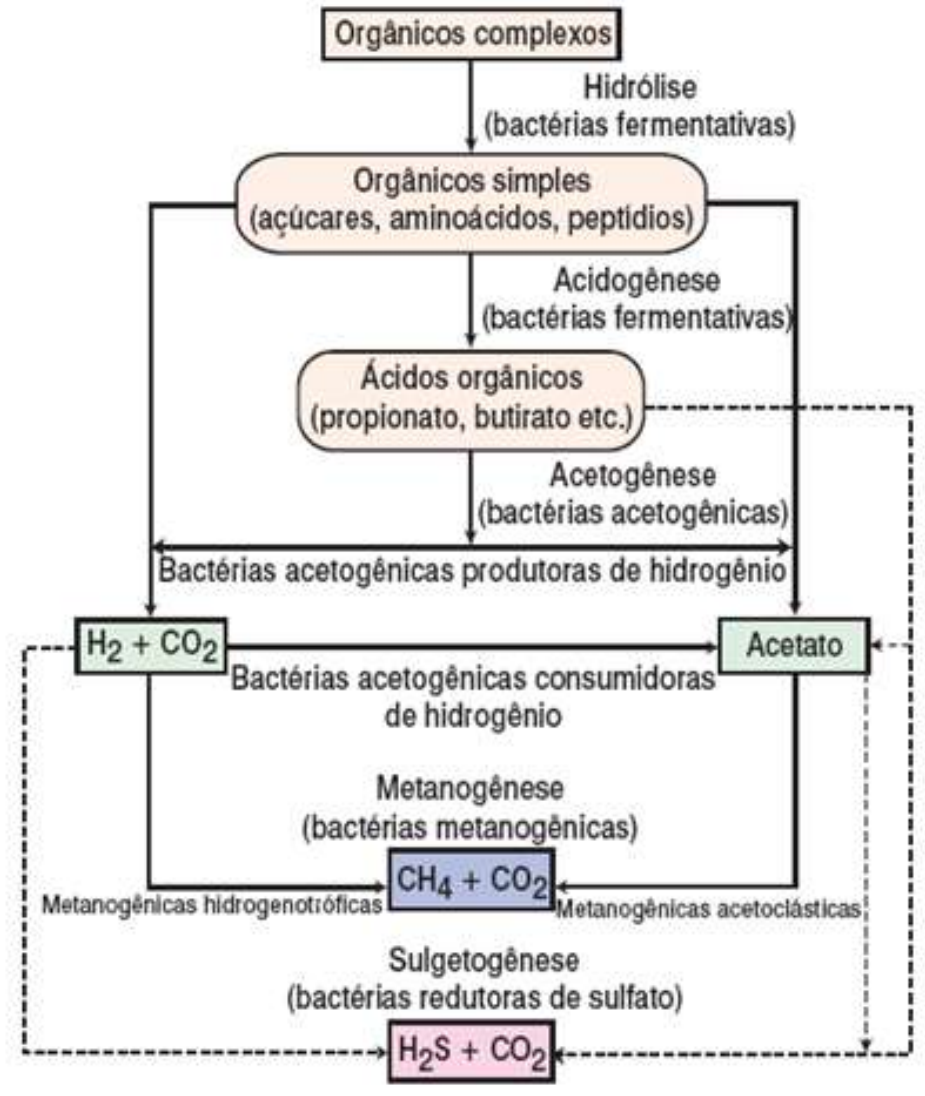

Fonte: Harpher e Pohland (1987); Chernicharo (1997).

Hidrólise Enzimática - Esta primeira fase do processo de degradação anaeróbia consiste na hidrólise de materiais particulados complexos (polímeros) em materiais dissolvidos mais simples (moléculas menores). Como as bactérias não são capazes de assimilar a matéria orgânica particulada, essa conversão é conseguida através da ação de enzimas excretadas pelas bactérias hidrolíticas fermentativas. Segundo van Haandel \& Marais (1999), a hidrólise é um processo lento e normalmente limita a taxa de digestão anaeróbia.

Acidogênese - Os produtos solúveis oriundos da fase de hidrólise são metabolizados no interior das células das bactérias fermentativas, sendo convertidos em diversos compostos mais simples, os quais são excretados pelas células. Os compostos produzidos incluem ácidos graxos voláteis, álcoois, ácido lático, gás carbônico, hidrogênio, nitrogênio amoniacal, sulfeto de hidrogênio, além de novas células bacterianas. Como os ácidos voláteis são o principal produto dos organismos fermentativos, estes são usualmente designados como bactérias fermentativas acidogênicas. 
Acetogênese - As bactérias acetogênicas são responsáveis pela oxidação dos produtos gerados na fase acidogênica em substratos apropriados para as árqueas metanogênicas. Os produtos gerados pelas bactérias acetogênicas são o hidrogênio, o dióxido de carbono e o acetato. De todos os produtos metabolizados pelas bactérias acidogênicas, apenas o hidrogênio e o acetato podem ser utilizados diretamente pelas metanogênicas. Porém, pelo menos $50 \%$ da DQO biodegradável é convertida em propionato e butirato, os quais são posteriormente decompostos em acetato e hidrogênio pela ação das bactérias acetogênicas.

Metanogênese - A etapa final do processo de degradação anaeróbia de compostos orgânicos em metano e dióxido de carbono é efetuada pelas árqueas metanogênicas. Elas utilizam somente um limitado número de substratos, compreendendo ácido acético, hidrogênio/dióxido de carbono, ácido fórmico, metanol, metilaminas e monóxido de carbono. Em função de sua afinidade por substrato e magnitude de produção de metano, as metanogênicas são divididas em dois grupos principais, um que produz metano a partir de ácido acético ou metanol (metanogênicas acetoclásticas), e o segundo que produz metano a partir de hidrogênio e dióxido de carbono (metanogênicas hidrogenotróficas). Embora apenas poucas espécies de metanogênicas sejam capazes de produzir metano a partir do acetato, estas são normalmente os micro-organismos predominantes na digestão anaeróbia e são responsáveis por cerca de 60 a 70\% de toda produção, a partir do grupo metil do ácido acético. Ao contrário das acetoclásticas, praticamente todas as espécies conhecidas de árqueas metanogênicas são capazes de produzir metano a partir de hidrogênio e dióxido de carbono.

Tanto as metanogênicas acetoclásticas quanto as hidrogenotróficas são muito importantes na manutenção do curso da digestão anaeróbia, uma vez que estas são responsáveis pela função essencial de consumir o hidrogênio produzido nas fases anteriores. Com isso, é propiciado o abaixamento da pressão parcial deste gás no meio, tornando possível as reações de produção das acidogênicas e acetogênicas, que são inibidas acima de $10^{-4} \mathrm{~atm}$.

Caso o substrato contenha sulfatos ou compostos de enxofre ocorrerá a sulfetogênese, representado na Figura 16 pelas linhas tracejadas. A produção de sulfetos é um processo no qual o sulfato e outros compostos a base de enxofre são utilizados como aceptores de elétrons durante a oxidação de compostos orgânicos. 
Durante esse processo, sulfato, sulfito, e outros compostos sulfurados são reduzidos a sulfeto, através da ação de um grupo de bactérias anaeróbias estritas, denominadas bactérias redutoras de sulfato (ou bactérias sulforredutoras), que se dividem em dois grandes grupos;

- Bactérias sulforredutoras que oxidam seus substratos de forma incompleta até $o$ acetato.

- Bactérias sulforredutoras que oxidam seus substratos completamente até o gás carbônico.

Na ausência de sulfato, o processo de digestão anaeróbia ocorre de acordo com as sequências metabólicas representadas por linhas contínuas na Figura 17, e na sua presença, muitos dos compostos intermediários formados através dessas rotas metabólicas passam a ser utilizados pelas bactérias sulforredutoras, provocando uma alteração das rotas metabólicas (linhas tracejadas). Dessa forma, as bactérias sulforredutoras passam a competir com as fermentativas, acetogênicas e com as árqueas metanogênicas pelos substratos disponíveis.

De acordo com Lettinga Associates Foundation (2009), o biogás é o produto final de uma digestão anaeróbia bem sucedida, que contém em sua composição predominantemente metano e dióxido de carbono. Na Tabela 13 é mostrada uma comparação entre a composição do biogás e a do gás natural.

Tabela 13 - Comparação entre a composição do biogás e a do gás natural.

\begin{tabular}{lccc}
\hline Componente & Unidade & Gás Natural & Biogás \\
\hline Metano & \% em vol. & 87 & $53-70$ \\
Dióxido de carbono & $\%$ em vol. & 1,2 & $30-47$ \\
Nitrogênio & $\%$ em vol. & 0,3 & 0,2 \\
Oxigênio & $\%$ em vol. & 0 & 0 \\
Gás sulfídrico & ppm & $1-2$ & $0-10.000$ \\
Amônia & ppm & 0 & $<100$ \\
\hline
\end{tabular}

Fonte: Adaptado de Lettinga Associates Foundation (2009).

O gás sulfídrico pode causar problemas de corrosão na queima do biogás, reduzindo a vida útil dos motores e de outros equipamentos. Geralmente, é removido quando a concentração é superior a 500 ppm. A remoção dos compostos do biogás é muitas vezes chamada de lavagem e, além do gás sulfídrico, podem ser removidos também 
o vapor de água e o $\mathrm{CO}_{2}$, visando-se o aumento do poder calorífico. Este pode ser usado para cozinhar ou na geração de eletricidade. Para aplicações de pequena escala nos países em desenvolvimento, o gás é usado normalmente sem ser tratado (lavado), e $1 \mathrm{~m}^{3}$ (não lavado) permite 2 horas de cozimento ou a geração elétrica de $1,5 \mathrm{kWh}$. Uma quantidade de $2,5 \mathrm{~m}^{3}$ de biogás não lavado equivale a $1 \mathrm{~kg}$ de GLP (AGAMA, 2007).

Dentre os fatores intervenientes na digestão anaeróbia, pode-se citar os biológicos (bactérias e árqueas metanogênicas), físicos (temperatura, umidade, tamanho das partículas, compacidade), químicos $(\mathrm{pH}$, potencial redox, necessidade/disponibilidade de nutrientes, presença de compostos inibidores ou tóxicos) e operacionais (teor de sólidos secos ou voláteis, TDH, recirculação/agitação).

A temperatura é um dos parâmetros mais importantes para o processo de digestão anaeróbia. As reações químicas ocorrem mais rapidamente com o aumento da temperatura, mas o aumento é limitado, porque as propriedades de alguns compostos mudam com a temperatura, todavia, grandes aumentos da taxa podem ser obtidos antes dos processos serem interrompidos. Esta relação entre a temperatura e a taxa de reação também é válida para os processos biológicos, porque são de fato processos químicos que ocorrem dentro de organismos vivos (ou "controlados" por esses organismos), contudo os próprios micro-organismos também são sensíveis à temperatura, e assim, as possibilidades de aumento das taxas de reação com aumento da temperatura são limitadas, muito mais do que no caso de reações puramente químicas (LETTINGA ASSOCIATES FOUNDATION, 2009).

Diferentes grupos de micro-organismos se adaptam a diferentes faixas de temperatura para crescer, e cada grupo tem a sua própria temperatura ótima com máximas velocidades de reações. Em temperaturas mais baixas, normalmente, a atividade cai, mas os organismos não morrem. Na digestão anaeróbia, podem-se dividir os micro-organismos em três grupos distintos quanto às faixas de temperatura:

- 4 a $20^{\circ} \mathrm{C}$ : micro-organismos psicrófilos;

- 20 a $40^{\circ} \mathrm{C}$ : micro-organismos mesófilos;

- Acima de $40^{\circ} \mathrm{C}$ : micro-organismos termófilos. 
Em geral, as velocidades máximas de reação para os organismos psicrófilos são menores do que para os mesófilos, que são mais baixas do que para os termofilos. Os grupos de micro-organismos são muito diferentes para cada faixa. Portanto, um digestor não pode ser mudado alterando-se a faixa de temperatura operacional para outra, sem perda de atividade. Quando ocorre uma alteração drástica da temperatura, outros micro-organismos começam a crescer para assumir o processo (Figura 18). Isso é normalmente demorado devido às baixas taxas de crescimento celular dos micro-organismos anaeróbios (CHERNICHARO, 1997; CHRISTENSEN, 2011).

Figura 18: Faixas de temperaturas dos micro-organismos psicrófilos, mesófilos e termófilos.

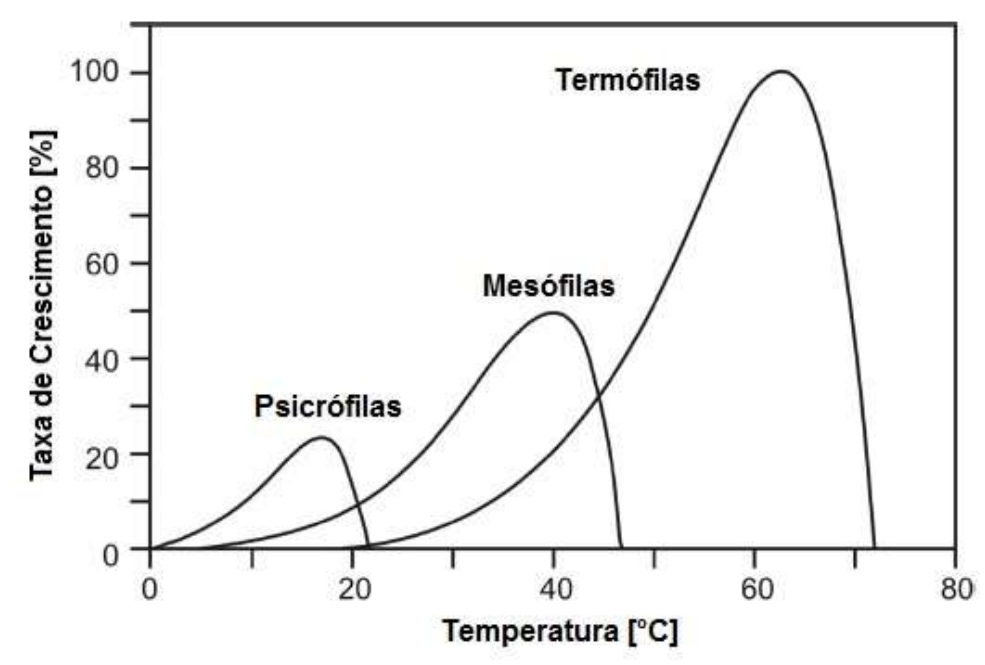

Fonte: Adaptado de Christensen (2011).

Outro parâmetro importante na digestão anaeróbia é o $\mathrm{pH}$, pois todos os organismos são mais ou menos sensíveis a alterações deste parâmetro, uma vez que ele afeta diretamente as reações enzimáticas. A faixa de $\mathrm{pH}$ ideal para o desenvolvimento da digestão anaeróbia é de 6,5 a 7,5 (TCHOBANOGLOUS et al, 1993; VAN HAANDEL \& MARAIS, 1999; WILLIANS, 2005). Os micro-organismos influenciam o pH do meio ambiente interno e externo, através da produção e/ou do consumo de ácidos orgânicos e compostos tamponantes. No entanto, apesar de poderem controlar o seu $\mathrm{pH}$ intracelular até um certo ponto, eles não podem regular o pH externo. Dos grupos de micro-organismos envolvidos na digestão anaeróbia, as árqueas metanogênicas são as mais sensíveis ao pH do seu ambiente, sendo a faixa ideal de 
6,5 a 8,0; abaixo de 6,0, a produção de metano é sensivelmente reduzida (LETTINGA ASSOCIATES FOUNDATION, 2009). As bactérias que são responsáveis pela hidrólise suportam uma ampla faixa de $\mathrm{pH}$, e as acidificantes preferem $\mathrm{pH}$ abaixo de 8, podendo produzir ácidos até um valor inferior a 5,0. Quando as acidificantes produzem mais ácido do que as metanogênicas conseguem consumir, o pH cai e o sistema entra em desequilíbrio, acidificando o reator (VAN HAANDEL \& MARAIS, 1999).

As necessidades de nutrientes dos micro-organismos são usualmente estabelecidas a partir da composição química de suas células (Tabela 14). Geralmente, o nitrogênio é o nutriente requerido em maiores concentrações para o crescimento dos micro-organismos, que o utilizam na forma orgânica ou amoniacal. Assumindo-se que eles estejam em uma forma biodisponível, os requisitos dependem do coeficiente de produção celular (CHERMICHARO, 1997):

Para biomassa com baixo coeficiente de produção celular:

$$
\text { DQO }: N: P: S=1000: 5: 1: 1 \text { ou } C: N: P: S=330: 5: 1: 1
$$

Para biomassa com elevado coeficiente de produção celular:

$$
\text { DQO }: N: P: S=350: 5: 1: 1 \text { ou } C: N: P: S=130: 5: 1: 1
$$

Tabela 14 - Composição química dos micro-organismos metanogênicos.

\begin{tabular}{lcllc}
\hline Macronutriente & Conc. $[\mathbf{g} / \mathbf{k g S S T}]$ & & Micronutriente & Conc. [mg/kgSST] \\
\cline { 1 - 2 } \cline { 5 - 5 } Nitrogênio & 65 & Ferro & 1800 \\
Fósforo & 15 & & Níquel & 100 \\
Potássio & 10 & & Cobalto & 75 \\
Enxofre & 10 & & Molibdênio & 60 \\
Cálcio & 4 & & Zinco & 60 \\
Magnésio & 3 & & Manganês & 20 \\
& & & Cobre & 10 \\
\hline
\end{tabular}

Fonte: Adaptado de Chernicharo (1997).

Os sistemas anaeróbios não removem efetivamente micro-organismos patogênicos como ocorre no processo de compostagem. Dependendo da origem da matéria orgânica, do seu grau de contaminação com micro-organismos e do uso que se deseja fazer dela, é recomendável sua desinfecção. Uma alternativa para 
desinfecção em sistemas termofílicos é trabalhar com tempos de detenção iguais ou superiores a 20 dias. Caso se pretenda fazer uso agrícola do composto, uma alternativa é a utilização de cal hidratada para desinfecção do composto ou a sua posterior compostagem aeróbia com elevação natural da temperatura (VAN HAANDEL \& MARAIS, 1999; LETTINGA ASSOCIATES FOUNDATION, 2009; CHRISTENSEN, 2011)

Segundo Mata-Alvarez, Macé e Llabrés (2000), a tecnologia de digestão anaeróbia de resíduos sólidos orgânicos pode ser considerada madura em muitos aspectos, tanto que já existem sistemas comerciais operando em larga escala, principalmente em países da Europa.

Existe uma série de diferentes tipos de sistemas de digestão anaeróbia de resíduos sólidos orgânicos, a saber:

- Baixo, médio ou alto teor de sólidos;

- Estágio único ou múltiplo;

- Alimentação contínua ou em batelada; e

- Faixa de temperatura mesofílica ou termofílica.

Os reatores são classificados como sistemas via úmida (BTS) quando o teor de sólidos totais (ST) está abaixo de $15 \%$ e via seca (ATS), quando este valor está entre 15 e 20\%. Entre estes valores, os reatores são considerados de médio teor de sólidos (VERMA, 2002; MATA-ALVAREZ, MACÉ, LLABRÉS, 2000). Sistemas de BTS utilizam um grande volume de água, resultando num maior volume do reator e altos custos de tratamento do efluente, que requer drenagem ao fim do processo. Os sistemas ATS são mais robustos e operam com altas taxas de carga orgânica, mas normalmente requerem equipamentos mais caros (VANDEVIVERE, DE BAERE, VERSTRAETE, 2003; KHANAL, 2008).

Os reatores de estágio único são os que utilizam somente um reator para as fases de acidogênese e metanogênese, enquanto os de estágio múltiplo, as separam em dois reatores. A separação tem como intuito melhorar a digestão, permitindo a flexibilização necessária para otimizar cada uma das etapas. Porém, a esperada vantagem da separação nem sempre é verificada na prática, resultando em processos mais complexos, que requerem maiores investimentos, com uma menor produção final de biogás. Todavia, sua maior vantagem reside numa taxa de 
alimentação mais constante na segunda etapa, principalmente no caso de substratos cuja degradação é limitada pela metanogênese (VANDEVIVERE; DE BAERE; VERSTRAETE; 2003). Desta forma, o reator de estágio múltiplo se torna mais viável para resíduos com baixo teor de celulose, sendo a única tecnologia aplicável para razão C:N menor que 20 (BJÖRSSON, 2012).

De acordo com Rapport et al. (2008) ${ }^{1}$ apud Naik; Tkachenko, Wung (2013), digestores de fase única são simples de projetar, construir e operar; geralmente, são mais baratos e representam cerca de $90 \%$ dos processos de digestão instalados na Europa.

Quanto ao regime de alimentação, o reator de batelada é muito mais utilizado que o de alimentação contínua, aplicado principalmente ao tratamento de excrementos de animais com baixo teor de sólidos. Ele é tecnicamente mais simples, barato e robusto, mas requer uma maior área de implantação (BJÖRSSON, 2012).

Segundo Naik; Tkachenko, Wung (2013), reatores de fluxo contínuo requerem um teor de sólidos mínimo de $20 \%$. Exemplos destes tipos de reatores são o Valorga; o Kompogas e o Dranco, todos eles patenteados. Já os sistemas em batelada compõem uma parcela menor do mercado e são melhores em processamento de biomassa lignocelulósica. A entrada de biomassa pode variar de 30-40\% de sólidos totais e é digerida em local estanque ao gás. A empresa alemã Bekon tem a maior quota de biodigestores de batelada do mercado.

Segundo Flor (2006), nos processos de via seca, obtêm-se as melhores taxas de produção de metano e as maiores cargas orgânicas aplicadas. Os desafios dessa via se concentram na manutenção das reações, nos altos teores de sólidos e na dificuldade de bombear os resíduos e homogeneizar o conteúdo dentro do reator.

Nos sistemas de elevada concentração de sólidos, os resíduos movem-se dentro do reator de modo tubular (plug-flow). No sistema Dranco, a mistura ocorre por recirculação dos resíduos extraídos pelo fundo do reator, e pela introdução de resíduos frescos, numa razão especifica de 1/6. No sistema Kompogas, esta é feita por meio de um sistema de agitação de baixa rotação, presente no interior do reator horizontal. No processo Valorga, a agitação ocorre pela injeção cíclica de biogás a

\footnotetext{
${ }^{1}$ RAPPORT J., ZHANG R., JENKINS B.M., \& WILLIAMS R.B. Current Anaerobic Digestion Technologies Used for Treatment of Municipal Organic Solid Waste. (2008) Disponível em: http://www.calrecycle.ca.gov/Publications/Documents/Organics\%5C2008011.pdf
} 
partir do fundo, sem necessidade de recircular o substrato digerido de volta para 0 reator. O processo Biocel nasceu da intenção de desenvolver um reator com facilidade de operação e manipulação, semelhante a um aterro sanitário, mas com produção de biogás e remoção de voláteis do resíduo e de DQO do lixiviado muito superiores. Os princípios de funcionamento se mantiveram, baseando-se na recirculação de lixiviado para aquecimento e mistura do conteúdo do reator (FLOR, 2006).

Um exemplo de reator com baixo teor de sólidos (via úmida) é o Linde-BRV, cuja característica marcante é o sistema de recirculação de biogás que utiliza um tubo que também serve para aquecer o conteúdo do reator.

A Figura 19 mostra esquemas dessas cinco tecnologias anteriormente descritas.

Figura 19 - Digrama simplificado de diferentes processos de digestão anaeróbia. (A) Kompogas, (B) Valorga, (C) Linde- BRV, (D) Dranco, (E) Biocel
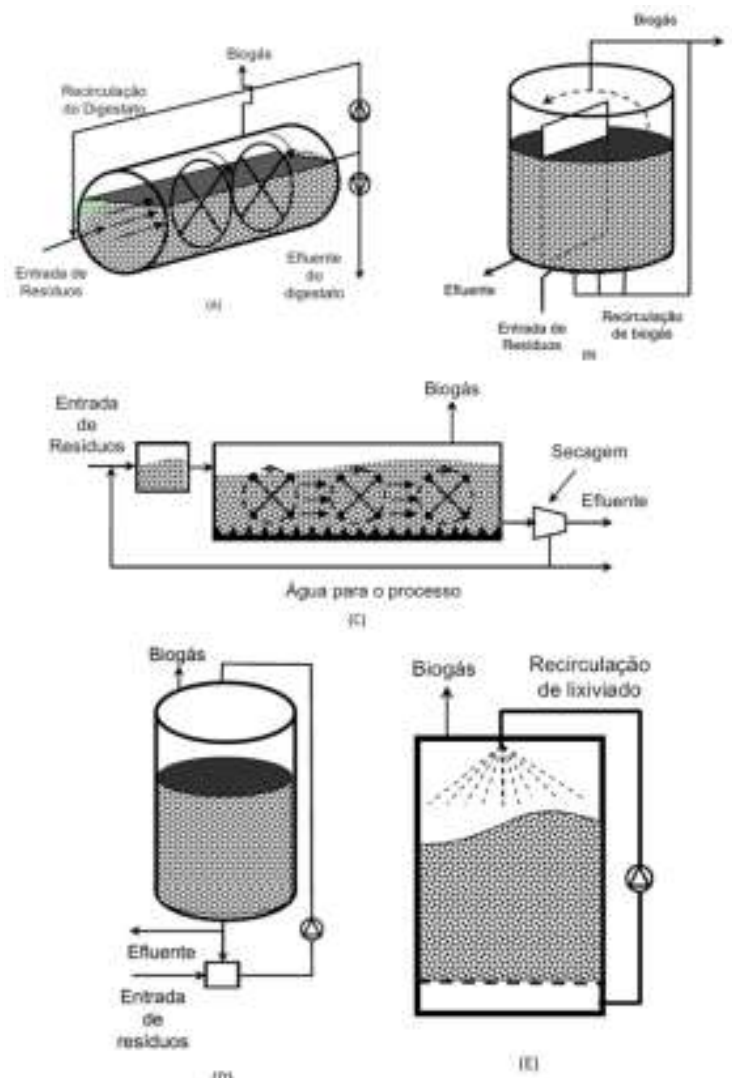

(8)

Fonte: Nayono (2010).

Classificando a operação por faixa de temperatura, têm-se as seguintes: mesofílica, entre $35^{\circ} \mathrm{C}$ e $40^{\circ} \mathrm{C}$; e termofílica, entre $50^{\circ} \mathrm{C}$ e $60^{\circ} \mathrm{C}$. Tradicionalmente, as estações 
de tratamento de digestão anaeróbia operavam na faixa mesofílica, dada a dificuldade de controlar a temperatura do digestor em faixas elevadas. Temperaturas acima de $70^{\circ} \mathrm{C}$ podem inativar as bactérias responsáveis pela digestão do resíduo. Porém, a tecnologia termofílica já está consolidada e, apesar de ser mais cara e menos estável que a mesofílica, tem como vantagens a higienização do resíduo, menor tempo de detenção hidráulico e maior produção de biogás (BJÖRSSON, 2012).

Existem muitos trabalhos na literatura apresentando diferentes configurações de digestores anaeróbios tratando matéria orgânica, ou mais especificamente, a fração orgânica dos RSU, obtendo-se resultados que podem servir de referência para a presente pesquisa, como os apresentados a seguir:

Pavan et al. (1999a) apud Mata-Alvarez, Macé e Llabrés (2000), utilizando um digestor termofílico de duas fases, tratando resíduos do comércio de frutas e vegetais, em condições ótimas (não informadas), e resíduos com altos teores de sólidos, com tempo de detenção de 12 dias, obtiveram uma produção de biogás de $600 \mathrm{~mL} \cdot \mathrm{gsTV}^{-1}$.

Bouallagui et al. (2005), em sua revisão bibliográfica, compararam o desempenho de várias configurações de digestores anaeróbios para o tratamento de resíduos de frutas e vegetais. As características dos sistemas e os resultados obtidos, bem como os demais estudos citados, estão listados na Tabela 15.

Zhang et al. (2007) utilizaram resíduos alimentares recolhidos e preparados em uma estação de transbordo da cidade de São Francisco na Califórnia para alimentação de um sistema de digestão anaeróbia. As variações diárias e semanais de composição dos resíduos foram medidas ao longo de um período de dois meses. $A$ biodegradabilidade anaeróbia e a produção de biogás e metano foram avaliadas por meio de testes de digestão anaeróbia, realizados em reatores de $1 \mathrm{~L}$, operados em bateladas, a $50 \pm 2{ }^{\circ} \mathrm{C}$, com volume útil de $0,5 \mathrm{~L}$. A média diária do teor de umidade e da relação entre sólidos voláteis e sólidos totais (SV/ST) foram determinadas por amostragens ao longo de uma semana, ficando em $70 \%$ e $83 \%$, respectivamente, enquanto a média semanal da umidade e da relação SV/ST foi de $74 \%$ e $87 \%$,

\footnotetext{
${ }^{2}$ PAVAN, P., BATTISTONI, P., TRAVERSO, P.G., CECCHI, F., MATA-ALVAREZ, J., 1999a. Two-phase anaerobic digestion of source sorted of MSW: performance and kinetic study. In: Mata-Alvarez, J., Tilche, A., Cecchi, F. (Eds.), Proceedings of the Second International Symposium on Anaerobic Digestion of Solid

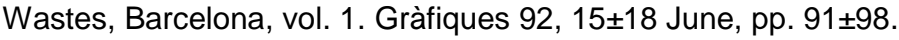


respectivamente. Análises do teor de nutrientes mostraram que o resíduo de alimentos continha nutrientes em quantidades equilibrados para micro-organismos anaeróbios e relação $\mathrm{C} / \mathrm{N}$ igual a 14,8:1. A produção de metano observada foi de 348 e $435 \mathrm{~mL}_{\text {Metano. }} \mathrm{gsv}^{-1}$ para os tempos de detenção de 10 e 28 dias, respectivamente. $O$ teor médio de metano do biogás foi de $73 \%$ e a remoção média de SV de $81 \%$.

Zhang e Jahng (2012) avaliaram se a digestão anaeróbia de resíduos provenientes da fração orgânica dos RSU seria estável a longo prazo com a suplementação de alguns elementos traço. Os reatores semi-contínuos de fase única eram frascos com volume útil de $150 \mathrm{~mL}$, mantidos a $37^{\circ} \mathrm{C}$. A adição dos suplementos manteve 0 sistema estável por 368 dias, com cargas orgânicas de 2,19 a 6,64 gsv. $\mathrm{L}^{-1} \cdot \mathrm{d}^{-1}$, com TD de 20 a 30 dias e elevadas produções de metano foram obtidas - entre 352 e 450 $\mathrm{mL}_{\text {Metano. }} \mathrm{gsv}^{-1}$ - não se observando acumulação significativa de ácidos voláteis. Uma investigação posterior sobre os efeitos da suplementação de alguns elementos (Co, $\mathrm{Fe}, \mathrm{Mo}$ e $\mathrm{Ni}$ ) mostrou que o ferro foi essencial para a manutenção da produção estável de metano.

Wan et al. (2013), utilizando um digestor anaeróbio termofílico de estágio único, tratando uma mistura de resíduos de alimentos, papel e plástico numa proporção de 2:1:1, obtiveram uma produção de biogás e de metano, respectivamente, de 592,4 e $370,1 \mathrm{~mL} \mathrm{gstV}^{-1}$.

No Brasil, a digestão anaeróbia de resíduos teve início com a digestão de dejetos da criação intensiva de animais, tais como, suínos, bovinos, aves, etc., provenientes da agroindústria, e nas últimas décadas, tem como objetivo o tratamento da fração orgânica dos RSU. Dentre esses trabalhos, pode-se citar os desenvolvidos por Picanço (2004), Carneiro (2005) e Dillenburg (2006), que utilizaram sistemas mesofílicos em bateladas com tempos de detenção variando de 70 a 110 dias (Tabela 15). Na pesquisa de Picanço (2004), a produção de metano variou entre 240 e $300 \mathrm{~mL} \mathrm{gsTV}^{-1}$. 
Tabela 15 - Dados de desempenho de diferentes processos de digestão anaeróbia aplicadas para o tratamento de resíduos sólidos orgânicos (continua).

\begin{tabular}{|c|c|c|c|c|c|c|c|c|c|c|c|c|c|}
\hline Processo & $\begin{array}{l}\text { Vol. } \\
{[\text { LL] }}\end{array}$ & $\begin{array}{l}\text { TDH } \\
\text { ou TR } \\
\text { [dia] }\end{array}$ & $\begin{array}{l}\text { Orig. do } \\
\text { Resíd. } \\
\text { Orgânico }\end{array}$ & $\begin{array}{c}\mathbf{U} \\
{[\%]}\end{array}$ & $\begin{array}{l}\text { STV }_{\text {Inic. }} \\
{[\%]}\end{array}$ & $\begin{array}{c}\mathrm{T} \\
{\left[{ }^{\circ} \mathrm{C}\right]}\end{array}$ & $\begin{array}{c}\mathrm{CO}_{\text {Aplic }} \\
{\left[g_{\text {stv }} \cdot L^{-1} \cdot d^{-1}\right]}\end{array}$ & $\mathrm{pH}$ & $\begin{array}{c}\text { ST }_{\text {Rem. }} \\
\text { [\%] }\end{array}$ & $\begin{array}{c}\text { STV } \\
\text { [\%] }\end{array}$ & $\begin{array}{l}\mathrm{CH}_{4} \\
{[\%]}\end{array}$ & $\begin{array}{l}\text { Prod. de } \\
\text { CH }_{4} \\
{\left[\text { L.gstv }^{-1}\right]}\end{array}$ & Fonte: \\
\hline $\begin{array}{l}\text { Reator de mistura } \\
\text { completa, contínuo de } 1 \\
\text { fase }\end{array}$ & 16 & 23 & $\begin{array}{l}\text { Frutas e } \\
\text { verduras }\end{array}$ & ND & ND & ND & 3,6 & ND & ND & 83 & ND & 0,37 & $\begin{array}{c}\text { Verrier et al. (1987) } \\
\text { apud Bouallagui et al. } \\
\text { (2005) }\end{array}$ \\
\hline $\begin{array}{l}\text { Sistema de } 2 \text { fases: } \\
\text { hidrolisador de mistura } \\
\text { completa e filtro anaeróbio }\end{array}$ & $7+4$ & $2+2,3$ & $\begin{array}{l}\text { Frutas e } \\
\text { verduras }\end{array}$ & ND & ND & ND & 5,65 & ND & ND & 96 & ND & 0,42 & $\begin{array}{c}\text { Verrier et al. (1987) } \\
\text { apud Bouallagui et al. } \\
\text { (2005) }\end{array}$ \\
\hline $\begin{array}{l}\text { Reator de mistura } \\
\text { completa, contínuo, de } 1 \\
\text { fase }\end{array}$ & 3 & 20 & $\begin{array}{l}\text { Frutas e } \\
\text { verduras }\end{array}$ & ND & ND & ND & 1,6 & ND & ND & 88 & ND & 0,47 & $\begin{array}{l}\text { Mata-Alvarez et al. } \\
\quad(1992)^{4} \text { apud } \\
\text { Bouallagui et al. (2005) }\end{array}$ \\
\hline Sistema Batelada & 10 & 47 & $\begin{array}{l}\text { Frutas e } \\
\text { verduras }\end{array}$ & ND & ND & ND & 1,06 & ND & ND & 65 & ND & 0,16 & $\begin{array}{l}\text { Rajeshwari et al., } \\
\quad(1998)^{5} \text { apud } \\
\text { Bouallagui et al. (2005) }\end{array}$ \\
\hline $\begin{array}{l}\text { Sistema de } 2 \text { fases: } \\
\text { hidrolisador ASBR e filtro } \\
\text { anaeróbio }\end{array}$ & $\begin{array}{l}2,5 \\
+10\end{array}$ & $7+10$ & $\begin{array}{l}\text { Frutas e } \\
\text { verduras }\end{array}$ & ND & ND & ND & 4,4 & ND & ND & 87,5 & ND & 0,34 & $\begin{array}{l}\text { Ruynal et al. }(1998)^{6} \\
\text { apud Bouallagui et al. } \\
(2005)\end{array}$ \\
\hline $\begin{array}{l}\text { Sistema termofílico de } 2 \\
\text { fases, alto teor de sólidos. }\end{array}$ & ND & 12 & $\begin{array}{l}\text { Frutas e } \\
\text { vegetais }\end{array}$ & ND & ND & ND & ND & ND & ND & ND & ND & $0,60^{(\mathrm{a})}$ & $\begin{array}{l}\text { Pavan et al. (1999a) } \\
\text { apud Mata-Alvarez, } \\
\text { Macé e Llabrés (2000) }\end{array}$ \\
\hline Sistema Batelada & 5 & 32 & $\begin{array}{l}\text { Frutas e } \\
\text { verduras }\end{array}$ & ND & ND & ND & 0,9 & ND & ND & 58 & ND & 0,26 & $\begin{array}{l}\text { Bouallagui et al. } \\
(2001)^{7} \text { apud } \\
\text { Bouallagui et al. (2005) }\end{array}$ \\
\hline
\end{tabular}

3 VERRIER D, RAY F, ALBAGNAC G. Two-phase methanization of solid vegetable wastes. Biol Wastes 1987;22:163-77.

${ }^{4}$ MATA-ALVAREZ J, CECCHI F, LLABRÉS P, PAVAN P. Anaerobic digestion of the Barcelona central food market organic wastes: plant design and feasibility study. Bioresour Technol 1992;42:33-42

${ }^{5}$ RAJESHWARI KV, PANTH DC, LATA K, KISHORE VVN. Studies on biomethanation of vegetable market waste. Biogas Forum 1998;3:4-11.

${ }^{6}$ RUYNAL J, DELGENES JP, MOLETTA R. Tow phase anaerobic digestion of solid waste by a multiple liquefaction reactors process. Bioresour Technol 1998;65:97103.

BOUALLAGUI H, BEN CHEIKH R, MAROUANI L, ET HAMDI M. Fermentation méthanique des déchets solides en batch. Premières journées scientifiques de

l'Association Tunisienne de Biotechnologie du 9-11 Février 2001. 
Tabela 15 - Dados de desempenho de diferentes processos de digestão anaeróbia aplicadas para o tratamento de resíduos sólidos orgânicos (Continuação).

\begin{tabular}{|c|c|c|c|c|c|c|c|c|c|c|c|c|c|}
\hline Processo & $\begin{array}{l}\text { Vol. } \\
\text { [L] }\end{array}$ & $\begin{array}{c}\text { TDH } \\
\text { ou TR } \\
\text { [dia] }\end{array}$ & $\begin{array}{l}\text { Orig. do } \\
\text { Resíd. } \\
\text { Orgânico }\end{array}$ & $\begin{array}{c}\text { U } \\
{[\%]}\end{array}$ & $\begin{array}{l}\text { STV }_{\text {Inic }} \\
{[\%]}\end{array}$ & $\begin{array}{c}\mathbf{T} \\
{\left[{ }^{\circ} \mathbf{C}\right]}\end{array}$ & $\begin{array}{c}\mathrm{CO}_{\text {Aplic }} \\
{\left[\mathrm{g}_{\mathrm{sTV}} \cdot \mathrm{L}^{-1} \cdot \mathrm{d}^{-1}\right]}\end{array}$ & $\mathrm{pH}$ & $\begin{array}{l}\text { ST }_{\text {Rem. }} \\
{[\%]}\end{array}$ & $\begin{array}{c}\text { STV }_{\text {Rem }} \\
\cdot \\
{[\%]}\end{array}$ & $\begin{array}{l}\mathrm{CH}_{4} \\
{[\%]}\end{array}$ & $\begin{array}{l}\text { Prod. de } \\
\text { CH }_{4} \\
{\left[\text { L.gstv }^{-1}\right]}\end{array}$ & Fonte: \\
\hline $\begin{array}{l}\text { Sistema de } 2 \text { fases: } \\
\text { hidrolisador de leito } \\
\text { sólido e UASB }\end{array}$ & $100+25$ & 2,5 & $\begin{array}{l}\text { Frutas e } \\
\text { verduras }\end{array}$ & ND & ND & ND & 6,8 & ND & ND & 94 & ND & 0,35 & $\begin{array}{c}\text { Rajeshwari et al. } \\
\qquad(2001)\end{array}$ \\
\hline $\begin{array}{l}\text { Reator Tubular } \\
\text { Contínuo }\end{array}$ & 18 & 20 & $\begin{array}{l}\text { Frutas e } \\
\text { verduras }\end{array}$ & ND & ND & ND & 2,8 & ND & ND & 76 & ND & 0,45 & $\begin{array}{c}\text { Bouallagui et al. } \\
(2003)^{8} \text { apud } \\
\text { Bouallagui et al. } \\
(2005)\end{array}$ \\
\hline $\begin{array}{l}\text { Sistema Batelada: } 1 \\
\text { fase }\end{array}$ & 50 & 110 & FORSU & 75 & 20,0 & $35 \pm 1$ & 0,55 & $5,8-8,7$ & 82 & 92 & $0-67,5$ & 0,24 & $\begin{array}{l}\text { Picanço, A. P. } \\
(2004)\end{array}$ \\
\hline $\begin{array}{l}\text { Sistema Batelada: } \\
\text { reator hidrolítico+ } \\
\text { Filtro anaeróbio }\end{array}$ & $50+28,8$ & 110 & FORSU & 75 & 20,0 & $35 \pm 1$ & 0,35 & $\begin{array}{l}6,1-8,8 \\
7,4-9,0\end{array}$ & 88 & 91 & $\begin{array}{l}0-75 \\
0-67,6\end{array}$ & 0,30 & $\begin{array}{l}\text { Picanço, A. P. } \\
\text { (2004) }\end{array}$ \\
\hline $\begin{array}{l}\text { Sistema Batelada: de } \\
2 \text { fases: sólida+ } \\
\text { líquida }\end{array}$ & $50+17,6$ & 95 & FORSU & 87 & 26,0 & $35 \pm 1$ & 1,1 & $>7,3$ & 50,5 & 62 & $\begin{array}{l}5-64 \\
5-68\end{array}$ & ND & $\begin{array}{l}\text { Carneiro, P. H. } \\
\quad(2005)\end{array}$ \\
\hline $\begin{array}{l}\text { Sistema Batelada: } \\
\text { reator de sólido+ filtro } \\
\text { anaeróbio }\end{array}$ & $50+3,3$ & 70 & FORSU & 73 & 21,9 & $35 \pm 1$ & ND & $\begin{array}{l}5,4-7,9 \\
7,5-8,2\end{array}$ & 60 & 74 & $\begin{array}{l}8-46 \\
11-14\end{array}$ & ND & $\begin{array}{c}\text { Dillenburg, M. E. } \\
(2006)\end{array}$ \\
\hline Sistema Batelada & 1,0 & 28 & FORSU & 74 & 26,4 & $50 \pm 2$ & 0,38 & 7,57 & ND & 81 & 73 & 0,44 & $\begin{array}{l}\text { Zhang et al. } \\
(2007)\end{array}$ \\
\hline Sistema Batelada & 0,15 & 30 & FORSU & 81,9 & 13,3 & 37 & 6,64 & 7,4 & ND & ND & 52,7 & 0,45 & $\begin{array}{l}\text { Zhang e Jahng } \\
(2012)\end{array}$ \\
\hline $\begin{array}{l}\text { Reator de único } \\
\text { estágio com agitação }\end{array}$ & 500 & 50 & $\begin{array}{c}\text { FORSU + } \\
\text { plástico + } \\
\text { papel }(2: 1: 1)\end{array}$ & 81,1 & 17,0 & $38 \pm 1$ & ND & 7,2 & 46 & 69 & 57 & 0,37 & $\begin{array}{l}\text { Wan et al. } \\
\text { (2013) }\end{array}$ \\
\hline
\end{tabular}

(a) Produção de biogás (não informado a \% de metano); ND = Não disponibilizado pelos autores.

${ }^{8}$ BOUALLAGUI H, HAOUARI O, TOUHAMI Y, BEN CHEIKH R, MAROUANI L, HAMDI M. Effect of temperature on the performance of an anaerobic tubular reactor treating fruit and vegetable waste. Process Biochem 2003, in press. 


\subsection{Filtros Anaeróbios e Variantes}

Segundo Andrade Neto et al. (1999), os filtros anaeróbios mais comuns consistem em tanques cheios de pedras britadas ou outro material inerte, sintético ou natural, que servem como meio suporte para aderência e desenvolvimento de microorganismos, constituindo um leito com elevado grau de vazios, por onde escoa uma água residuária em fluxo ascendente, horizontal ou descendente.

Nos filtros de fluxo ascendente, que são os mais comuns, o líquido entra pela base, é distribuído por um fundo falso ou por tubos perfurados, flui através do material de enchimento e é descarregado pelo topo, coletado em canaletas. Na superfície do material de enchimento ocorre a adesão e o desenvolvimento de micro-organismos na forma de biofilme e, no filtro afogado, principalmente nos de fluxo ascendente, também se agrupam micro-organismos na forma de flocos ou grânulos nos interstícios do meio suporte. Nesse sistema, o líquido a ser tratado escoa pelos interstícios, em contato com os micro-organismos aderidos, com o objetivo de propiciar um maior tempo de retenção celular e maior tempo de contato entre o líquido e a biomassa. Este sistema é um dos menos susceptíveis à perda de biomassa e, além disso, é relativamente estável, resistindo bem às variações de carga do afluente. Todavia, o material de enchimento ocupa boa parte do volume do reator e o líquido a ser tratado não deve conter sólidos grosseiros.

Em sistemas de tratamento e disposição final de resíduos sólidos, os filtros anaeróbios são normalmente utilizados para tratamento ou pré-tratamento de lixiviados de aterros sanitários. Dentre os trabalhos encontrados na literatura, destacam-se os listados a seguir, cujos dados e resultados mais relevantes encontram-se na Tabela 16.

Timur e Özturk (1997), para tratamento de lixiviados de um aterro sanitário considerado jovem, utilizando um filtro anaeróbio de leito híbrido, conseguiram eficiência de remoção de COT de 81,4\%, com tempo de detenção hidráulico (TDH) de 2,4 dias, com um filtro de volume total igual a 3,35 L.

Timur et al. (2000), operando o mesmo sistema de Timur e Özturk (1997), com TDH variando de 5,1 a 0,9 dias, obtiveram eficiências de remoção de DQO entre 87,0 e $59,3 \%$, conforme aumentaram a concentração afluente de DQO de aproximadamente $3.955 \mathrm{mg} \cdot \mathrm{L}^{-1}$ para $14.950 \mathrm{mg} \cdot \mathrm{L}^{-1}$. 
Inanc et al. (2000) operaram três reatores anaeróbios, tratando lixiviados de um aterro sanitário de Istambul, com concentrações, em termos de DQO, de 18.800 a $47.800 \mathrm{mg} \cdot \mathrm{L}^{-1}$ e relação $\mathrm{DBO}_{5} / \mathrm{DQO}$ maior que 0,7 para a maioria das amostras coletadas. Foram comparados três tipos de reatores: um reator anaeróbio de fluxo ascendente com manto de lodo (RAFA, também conhecido como UASB), um filtro anaeróbio de fluxo ascendente e um reator de leito híbrido, com volumes efetivos de 7,85 L cada um e TDH de 2,4 a 2,0 dias. Todos os sistemas apresentaram desempenho similar com o aumento da carga orgânica aplicada, atingindo eficiências entre 80 e $90 \%$.

A partir de meados de 2010, uma nova configuração de filtro biológico começou a ser pesquisada para tratamento de lixiviados de aterros sanitários, que numa tradução literal podem ser chamados de "biofiltros de resíduos envelhecidos" (BRE). Estes biofiltros são considerados pela literatura como sistemas semi-aeróbios, pois possuem em seu interior zonas aeróbias, anóxicas e anaeróbias. Alguns trabalhos utilizando estes novos biofiltros são apresentados a seguir.

Li et al. (2010), em um projeto de demonstração, construíram um sistema de BRE em duas fases, utilizando cerca de $7.000 \mathrm{~m}^{3}$ de resíduos provenientes do aterro de Changai, que haviam sido aterrados há aproximadamente 8 anos. Os dois compartimentos trabalhavam em série, recebendo cerca de $100 \mathrm{~m}^{3} /$ dia de lixiviados, que eram bombeados e aspergidos na superfície dos dois compartimentos. Foram atingidas eficiências superiores a $64 \%$ para $\mathrm{DQO}$, entre 95,8\% e 99,8\% para $\mathrm{DBO}_{5}$ e entre $96,9 \%$ e $99,8 \%$ para $\mathrm{N}-\mathrm{NH}_{3}$. As concentrações afluentes dos mesmos variaram entre $986-4.128 \mathrm{mg} / \mathrm{L}, 264-959 \mathrm{mg} / \mathrm{L}$ e $538-1.583 \mathrm{mgN} / \mathrm{L}$, respectivamente.

Han et al. (2011) operaram um biofiltro semi-aeróbio com leito de resíduo, proveniente de uma escavação no aterro de Chang An em Chengdu, localizada no sudoeste da China. O material tinha tamanho de partícula uniforme, alta porosidade, baixo teor de umidade $(31,84 \%)$, teor de matéria orgânica considerado típico (65 $\mathrm{g} / \mathrm{kg}$ ) e havia sido peneirado para remoção de partículas maiores do que $10 \mathrm{~mm}$ de diâmetro. Durante o experimento, a taxa de remoção de $\mathrm{DQO}$ e N-NH $\mathrm{N}_{3}$ obtidas foram de $99,1 \%$ e 99,3\%, respectivamente, com concentrações afluentes de $53.760 \mathrm{mg} / \mathrm{L}$ e $1.186 \mathrm{mgN} / \mathrm{L}$.

Xie et al. (2012) construíram uma instalação piloto, composta por um BRE e um biofiltro preenchido por escória (de origem não informada), operados em série no 
aterro de Shanghai Laogang na China, com alimentação de $20 \mathrm{~m}^{3} \cdot \mathrm{d}^{-1}$. As eficiências de remoção observadas no BRE para DQO, DBO e N-NH 3 foram de $59 \pm$ 4,3\%, $91 \pm$ 1,5\%, $66 \pm 6,6 \%$, respectivamente. Considerando-se os dois reatores em série, as eficiências finais para DQO, DBO e $\mathrm{N}^{-N_{3}}$ foram de $87 \pm 4,7 \%, 99 \pm 2,7 \%$ e $99 \pm$ $8,4 \%$, sendo as concentrações afluentes da ordem de $2.200 \mathrm{mg} / \mathrm{L}, 280 \mathrm{mg} / \mathrm{L}$ e 1.900 $\mathrm{mgN} / \mathrm{L}$, respectivamente.

Segundo Hassan e Xie (2014), apesar dos bons resultados apresentados pelos BRE para a remoção de diversos poluentes em lixiviados, tanto em escala de laboratório como em piloto, ainda são necessárias mais pesquisas para se eliminar as deficiências do sistema e desenvolver melhores formas de lidar com compostos recalcitrantes, aumentando suas remoções. Ainda segundo Hassan e Xie (2014), os BRE apresentam eficiências de 64 a 99\% para DQO, > 90\% para $\mathrm{DBO}_{5}$ e fósforo total, de 49 a 95\% para nitrogênio total e de 66 a 99,8\% para $\mathrm{N}-\mathrm{NH}_{3}$. Combinando os BRE com processos químicos, como precipitação química, oxidação avançada, processos eletroquímicos, etc., pode-se melhorar a eficiência de remoção de compostos recalcitrantes presentes no lixiviado.

Embora os tempos de detenção não tenham sido apresentados nos artigos de BRE, os mesmos foram calculados e resultaram em valores relativamente altos (70 a 125 dias), o que pode demandar grandes áreas e recursos para construção dessas unidades. 
Tabela 16 - Dados de desempenho de diferentes filtros anaeróbios aplicados ao tratamento de lixiviados de aterro sanitário.

\begin{tabular}{|c|c|c|c|c|c|c|c|c|c|c|c|c|}
\hline $\begin{array}{l}\text { Leito / enchimento } \\
\text { do biofiltro }\end{array}$ & $\begin{array}{c}\text { Dimensão } \\
{[\mathrm{m}]}\end{array}$ & $\begin{array}{l}\text { Vol. } \\
\text { [L] }\end{array}$ & $\begin{array}{l}\text { TDH } \\
\text { [dia] }\end{array}$ & Lixiviado & $\begin{array}{c}\mathbf{T} \\
{\left[{ }^{\circ} \mathbf{C}\right]}\end{array}$ & $\begin{array}{l}\text { DQO }_{\text {Inic. }} \\
{\left[\mathrm{mg}^{\left.-\mathrm{L}^{-1}\right]}\right.}\end{array}$ & $\begin{array}{l}\text { DBO }_{\text {Inic. }} \\
{\left[\mathrm{mg}^{-\mathrm{L}^{-1}}\right]}\end{array}$ & $\begin{array}{l}\mathrm{COT}_{\text {Inic. }} \\
{\left[\mathrm{mg} \cdot \mathrm{L}^{-1}\right]}\end{array}$ & $\begin{array}{l}\text { Carga org. } \\
{\left[\mathrm{KgDQO} \cdot \mathrm{m}^{-3} \cdot \mathrm{d}^{-1}\right]}\end{array}$ & $\begin{array}{l}\mathrm{N}-\mathrm{NH}_{3} \text { Inic. } \\
{\left[\mathrm{mgN}^{-1} \mathrm{~L}^{-1}\right]}\end{array}$ & $\begin{array}{c}\text { Eficiência } \\
\text { [\%] }\end{array}$ & Fonte: \\
\hline $\begin{array}{l}\text { Anéis plásticos }(\varnothing= \\
1,6 ; \text { Área sup. } \\
\left.\text { específica. } 322 \mathrm{~m}^{2} \cdot \mathrm{m}^{-3}\right)\end{array}$ & $\begin{array}{l}\varnothing=0,115 \\
h=0,322^{*}\end{array}$ & 3,35 & 2,4 & $\begin{array}{c}\text { Aterro } \\
\text { novo }\end{array}$ & - & - & - & $\begin{array}{c}1.250 \mathrm{a} \\
4.490\end{array}$ & 3,5 & - & 81,4 (СОT) & $\begin{array}{l}\text { Timur e } \\
\text { Özturk } \\
(1997)\end{array}$ \\
\hline $\begin{array}{l}\text { Anéis plásticos }(\varnothing= \\
1,6 \text {; Área sup. } \\
\left.\text { específica. } 322 \mathrm{~m}^{2} \cdot \mathrm{m}^{-3}\right)\end{array}$ & $\begin{array}{c}\varnothing=0,115 \\
\mathrm{~h}=0,322^{*}\end{array}$ & 3,35 & $\begin{array}{c}5,1 \mathrm{a} \\
0,9\end{array}$ & - & - & $\begin{array}{l}3.955 \mathrm{a} \\
14.950\end{array}$ & - & - & 0,8 a 16,5 & - & $\begin{array}{c}87,0 \text { a } 59,3 \\
\text { (DQO) }\end{array}$ & $\begin{array}{l}\text { Timur et } \\
\text { al (2000) }\end{array}$ \\
\hline- & - & 7,85 & $\begin{array}{c}2,4 \mathrm{a} \\
2,0\end{array}$ & $\begin{array}{l}\text { Aterro } \\
\text { novo }\end{array}$ & $35 \pm 2$ & $\begin{array}{c}18.800 \mathrm{a} \\
47.800\end{array}$ & - & - & 1,3 a 8,2 & - & $\begin{array}{c}90,0 \text { a } 80,0 \\
\text { (DQO) }\end{array}$ & $\begin{array}{l}\text { Inanc et } \\
\text { al (2000) }\end{array}$ \\
\hline $\begin{array}{l}2 \text { biofiltros iguais, em } \\
\text { série, de resíduos } \\
\text { envelhecidos (BRE) }\end{array}$ & $\begin{array}{c}h=3 \\
L_{\text {sup }}=59 \\
L_{f}=55 \\
w=45\end{array}$ & $\begin{array}{c}7,0 x \\
10^{6}\end{array}$ & $70^{*}$ & - & - & $\begin{array}{l}986 \mathrm{a} \\
4.128\end{array}$ & $\begin{array}{c}264 \mathrm{a} \\
959\end{array}$ & - & $\begin{array}{c}0,014^{*} a \\
0,059^{\star}\end{array}$ & $\begin{array}{l}538 \mathrm{a} \\
1.583\end{array}$ & $\begin{array}{l}>64,0 \text { (DQO); } \\
>95,0 \text { (DBO) }\end{array}$ & $\begin{array}{l}\text { Li et al } \\
(2010)\end{array}$ \\
\hline $\begin{array}{l}\text { Biofiltro com } 2 \text { leitos: } \\
\text { resíduos envelhecidos } \\
\text { (BRE) + pedra na base }\end{array}$ & $\begin{array}{c}\emptyset=0,3 ; \\
\mathrm{h}_{\text {BRE }}=0,9 ; \\
\mathrm{h}_{\text {pedras }}=0,2\end{array}$ & $78^{*}$ & $125^{*}$ & $\begin{array}{c}\text { Aterro } \\
\text { novo }\end{array}$ & 30 & 40.000 & - & - & 0,32 & 1.100 & 99,1 (DQO); & $\begin{array}{c}\text { Han et al } \\
\text { (2011) }\end{array}$ \\
\hline $\begin{array}{l}2 \text { biofiltros em série: } \\
\text { resíduos envelhecidos } \\
\text { (BRE); e escória }\end{array}$ & $\begin{array}{l}\text { Ambos: } 28 \\
\times 15 \times 2,8\end{array}$ & $\begin{array}{l}2,352 \\
\times 10^{6 *}\end{array}$ & $118^{*}$ & - & $\begin{array}{c}11 \mathrm{a} \\
20\end{array}$ & $\begin{array}{c}2.000 \mathrm{a} \\
3.200\end{array}$ & $\begin{array}{c}200 \mathrm{a} \\
320\end{array}$ & - & $\begin{array}{c}0,017^{*} a \\
0,027^{\star}\end{array}$ & $\begin{array}{l}1.700 \mathrm{a} \\
2.700\end{array}$ & $\begin{array}{l}87,0 \text { (DQO); } \\
99,0 \text { (DBO); }\end{array}$ & $\begin{array}{c}\text { Xie et al } \\
\text { (2012) }\end{array}$ \\
\hline
\end{tabular}

(*) Não informado pelo ator, calculado com base nos dados fornecidos. ( - ) Não disponibilizado pelos autores. 


\section{MATERIAL E MÉTODOS}

O experimento foi montado no Laboratório de Saneamento Prof. Lucas Nogueira Garcez do Departamento de Engenharia Hidráulica e Ambiental da Escola Politécnica da Universidade de São Paulo (EP-USP).

\subsection{Preparação e Conservação da Matéria Orgânica}

Visando garantir a homogeneidade das amostras durante toda a investigação experimental, procedeu-se como descrito a seguir:

Inicialmente, pequenas porções diárias da matéria orgânica dos resíduos descartados em uma residência foram armazenadas em sacos plásticos de polietileno de baixa densidade (PEBD) de $5 \mathrm{~L}$ e mantidas em refrigeração a $4 \pm 2{ }^{\circ} \mathrm{C}$ até se obter aproximadamente $8 \mathrm{~kg}$.

Concluída esta etapa, cada embalagem refrigerada foi aberta, e quando as mesmas atingiram a temperatura ambiente, foi feita uma separação do seu conteúdo nas seguintes frações:

- cascas e restos de frutas;

- restos de massas de pães e pizzas;

- folhas e talos vegetais (verduras e jardinagem);

- cascas de ovos;

- pó de café e papel filtro;

- restos e cascas de legumes;

- restos de carnes, peles e gorduras; e

- restos finais (grãos e cereais cozidos ou não, sementes e restos das frações anteriores, que devido à pequena quantidade ou estado de deterioração, não foi possível a total separação).

Separadas as frações, elas foram picadas em dimensões menores que $2,0 \mathrm{~cm}$, utilizando-se uma faca de cozinha, e em seguida, cada fração foi pesada em uma balança semi- analítica da marca Bel, modelo SSR3000, com capacidade máxima de $3,0 \mathrm{~kg}$, precisão de $0,2 \mathrm{~g}$ e resolução de $0,05 \mathrm{~g}$.

Definido o número de amostras que seria utilizado na investigação experimental, cada amostra foi composta por uma parte proporcional em massa de cada fração 
dos resíduos separados, conforme a Tabela 17. Dessa forma, procurou-se obter amostras representativas, composta por frações orgânicas de fácil, média e difícil biodegradação e até inorgânica, bem como com composições semelhantes entre si, para que fosse possível realizar comparações entre os resultados das diferentes bateladas.

Tabela 17 - Composição de cada uma das amostras de acordo com suas frações constituintes.

\begin{tabular}{|c|c|c|c|c|c|c|c|c|c|}
\hline \multirow[b]{2}{*}{ Amostra } & \multicolumn{8}{|c|}{ Massa de cada componente [g] } & \multirow[b]{2}{*}{$\begin{array}{c}\text { Total } \\
\text { [g] }\end{array}$} \\
\hline & $\begin{array}{c}\text { Cascas } \\
\text { de } \\
\text { Frutas }\end{array}$ & $\begin{array}{l}\text { Massas } \\
\text { de Pães } \\
\text { e Pizzas }\end{array}$ & $\begin{array}{c}\text { Folhas e } \\
\text { Talos } \\
\text { Vegetais }\end{array}$ & $\begin{array}{c}\text { Cascas } \\
\text { de } \\
\text { Ovos }\end{array}$ & $\begin{array}{l}\text { Pó e } \\
\text { filtro de } \\
\text { Café }\end{array}$ & $\begin{array}{l}\text { Restos e } \\
\text { Cascas de } \\
\text { Legumes }\end{array}$ & $\begin{array}{c}\text { Carnes } \\
\text { peles e } \\
\text { gorduras }\end{array}$ & $\begin{array}{l}\text { Restos } \\
\text { Finais }\end{array}$ & \\
\hline 1 & 132,35 & 23,95 & 48,15 & 2,00 & 46,35 & 41,30 & 14,90 & 125,25 & 434,25 \\
\hline 2 & 132,50 & 24,05 & 48,20 & 2,00 & 45,90 & 41,20 & 14,95 & 125,10 & 433,90 \\
\hline 3 & 132,50 & 23,95 & 48,25 & 2,00 & 46,00 & 41,30 & 14,90 & 125,05 & 433,95 \\
\hline 4 & 132,55 & 23,90 & 48,05 & 2,00 & 46,05 & 41,20 & 15,00 & 125,20 & 433,95 \\
\hline 5 & 132,55 & 23,95 & 48,15 & 2,00 & 45,95 & 41,10 & 15,00 & 125,20 & 433,90 \\
\hline 6 & 132,80 & 24,10 & 48,30 & 2,00 & 46,00 & 41,15 & 15,05 & 125,55 & 434,95 \\
\hline 7 & 132,70 & 23,95 & 48,05 & 2,00 & 46,30 & 41,20 & 14,95 & 125,35 & 434,50 \\
\hline 8 & 132,55 & 23,85 & 48,00 & 2,00 & 46,00 & 41,00 & 15,05 & 125,50 & 433,95 \\
\hline 9 & 132,75 & 24,15 & 48,25 & 2,00 & 46,05 & 41,25 & 15,20 & 125,20 & 434,85 \\
\hline 10 & 132,70 & 23,90 & 48,20 & 2,00 & 45,95 & 41,10 & 15,10 & 125,50 & 434,45 \\
\hline 11 & 132,50 & 23,95 & 48,20 & 2,00 & 46,10 & 41,10 & 14,95 & 125,60 & 434,40 \\
\hline 12 & 132,50 & 24,00 & 48,20 & 2,00 & 46,00 & 41,30 & 15,15 & 125,10 & 434,25 \\
\hline 13 & 132,80 & 24,00 & 48,10 & 2,00 & 46,10 & 41,00 & 15,00 & 125,45 & 434,45 \\
\hline 14 & 132,65 & 24,10 & 48,25 & 2,00 & 46,50 & 41,05 & 14,95 & 125,30 & 434,80 \\
\hline 15 & 132,50 & 24,05 & 48,20 & 2,00 & 46,30 & 41,50 & 14,95 & 125,30 & 434,80 \\
\hline 16 & 132,55 & 24,10 & 48,00 & 2,00 & 46,25 & 41,35 & 14,95 & 125,50 & 434,70 \\
\hline 17 & 132,65 & 23,95 & 48,15 & 2,00 & 46,20 & 41,25 & 15,05 & 125,60 & 434,85 \\
\hline Média & 132,59 & 23,99 & 48,16 & 2,00 & 46,12 & 41,20 & 15,01 & 125,34 & 434,41 \\
\hline DP & 0,12 & 0,08 & 0,09 & 0,00 & 0,17 & 0,13 & 0,08 & 0,18 & 0,38 \\
\hline $\begin{array}{c}\text { Fração } \\
\text { [\%] }\end{array}$ & 30,52 & 5,52 & 11,09 & 0,46 & 10,62 & 9,48 & 3,45 & 28,85 & 100,00 \\
\hline
\end{tabular}

OBS: DP = Desvio Padrão.

Após a composição de cada fração, todas as amostras foram acondicionadas em sacos plásticos de PEBD, com capacidade de $2 \mathrm{~L}$ cada, numerados e transportados para um freezer. Na Figura 20 são ilustradas as frações picadas do resíduo e o acondicionamento em saco plástico. 
Figura 20 - Composição das amostras com as frações picadas da matéria orgânica dos resíduos domiciliares.

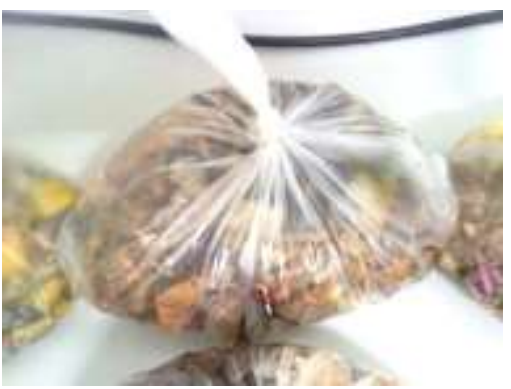

(a) Amostra final embalada

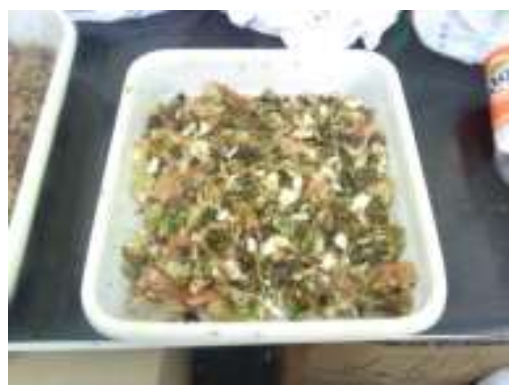

(d) Folhas e talos vegetais

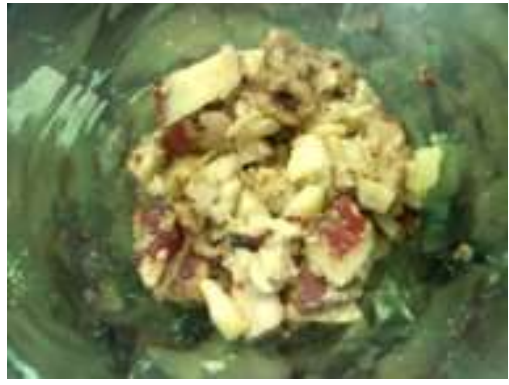

(g) Restos e cascas de legumes

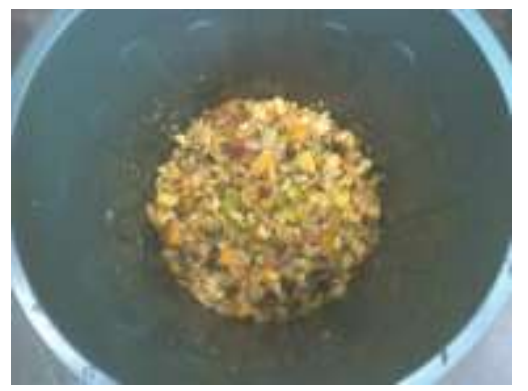

(b) Cascas e restos de frutas

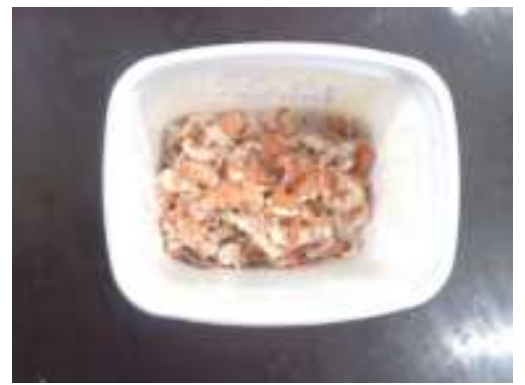

(e) Cascas de ovos

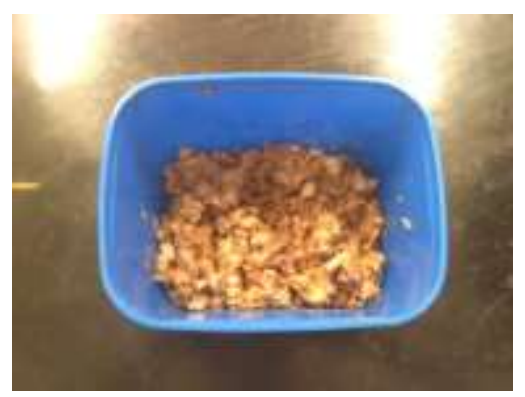

(h) Restos de carnes, peles e gorduras

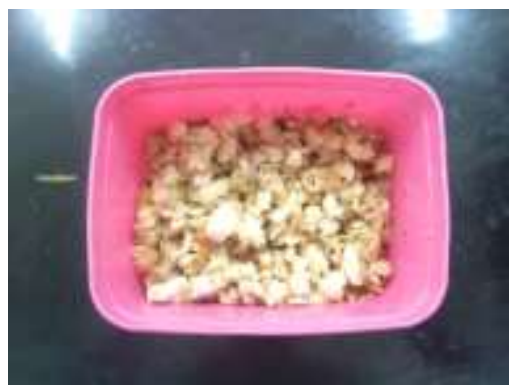

(c) Restos de massas

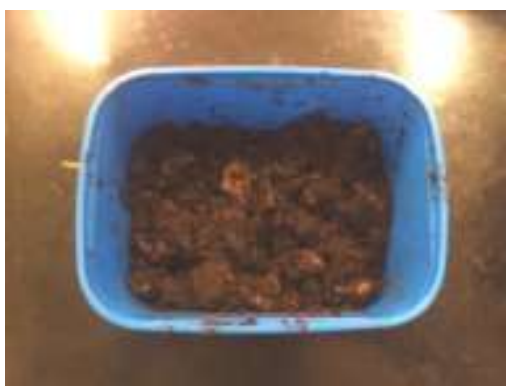

(f) Pó de café e papel filtro

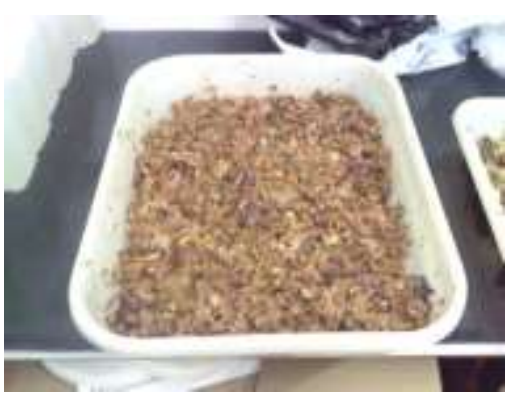

(i) Restos finais

Fonte: Autor.

Em cada batelada, as amostras foram selecionadas aleatoriamente a partir das congeladas e para sua utilização, as mesmas foram descongeladas com no mínimo $12 \mathrm{~h}$ de antecedência, em um recipiente estanque, para que não fossem perdidos os líquidos que se formam no descongelamento.

Dentre as amostras de resíduos sólidos armazenadas e congeladas para realização do experimento, uma delas foi selecionada para caracterização, também aleatoriamente. A amostra selecionada foi a número 05 , que foi descongelada e, posteriormente, triturada em um processador de alimentos por aproximadamente 5 minutos até se tornar uma massa homogênea com consistência pastosa. Dessa massa de aproximadamente $410 \mathrm{~g}$, foram coletadas 4 amostras de 
aproximadamente $50 \mathrm{~g}$ cada, que foram utilizadas para realização das análises de sólidos e umidade; o restante foi novamente congelado para realização posterior de análises químicas.

Com os resultados dessas quatro amostras, obtiveram-se as médias e os desvios padrão, que foram utilizados como referência para se estimar as características dos resíduos no início de cada batelada.

Ao final de cada batelada, o resíduo tratado foi recolhido no digestor, incluindo fragmentos e materiais particulados que ficaram aderidos ou escaparam para as mangueiras. Esse material foi quantificado por pesagem, obtendo-se a sua massa úmida e na sequência, ele foi homogeneizado e separado em três frações para realização das análises de sólidos e umidade.

\subsection{Coleta e Preparação do Inóculo}

A biomassa utilizada como inóculo no filtro anaeróbio foi coletada no fundo de uma lagoa anaeróbia de lixiviados desativada (Figura 21) do antigo aterro sanitário de São Carlos-SP (operação de 1991 a 2011).

Depois de coletado, o inóculo foi acondicionado em um recipiente de $10 \mathrm{~L}$ para transporte até o Laboratório de Saneamento da EP-USP, onde foi mantido a temperatura ambiente até sua preparação. Inicialmente, foi feito um peneiramento para eliminação de detritos vegetais e inorgânicos indesejados e, na sequencia, este lodo foi misturado ao meio suporte, que era formado por uma composição de segmentos de 1,0 a $1,5 \mathrm{~cm}$ de bobes de cabelo, preenchidos com espuma de poliuretano, densidade $20 \mathrm{~kg} \cdot \mathrm{m}^{-3}$, conforme ilustra a Figura 22. 
Figura 21 - Local de coleta do inóculo no fundo de uma lagoa de lixiviados do antigo aterro sanitário de São Carlos-SP.

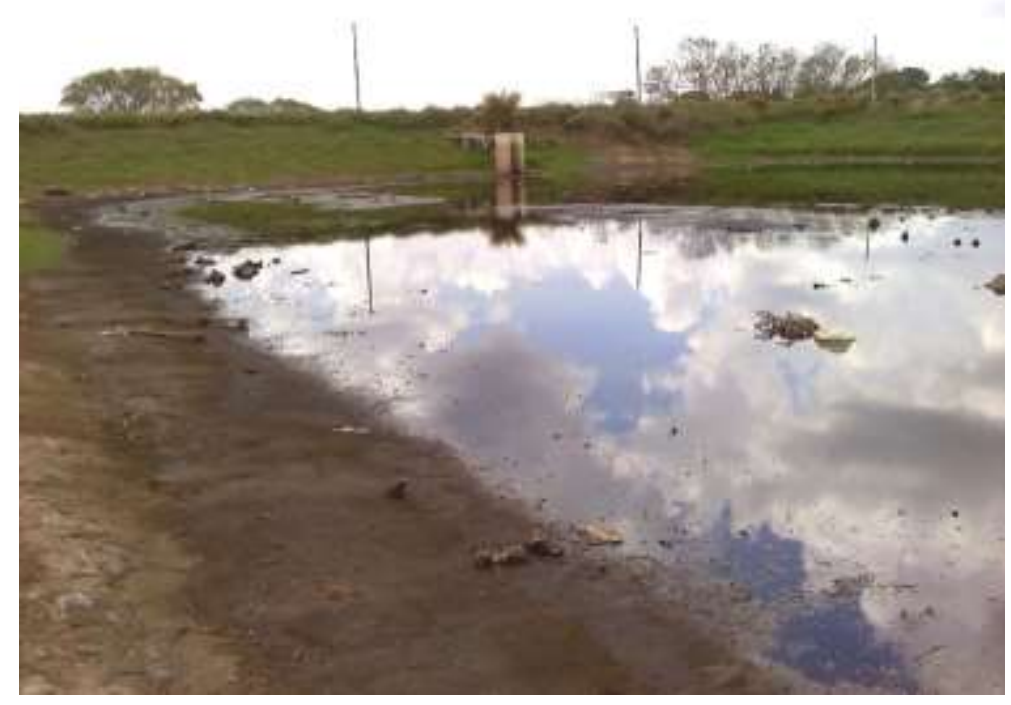

Fonte: Autor.

Figura 22 - (a) Inóculo antes da preparação e (b) meio suporte antes e depois da inoculação.

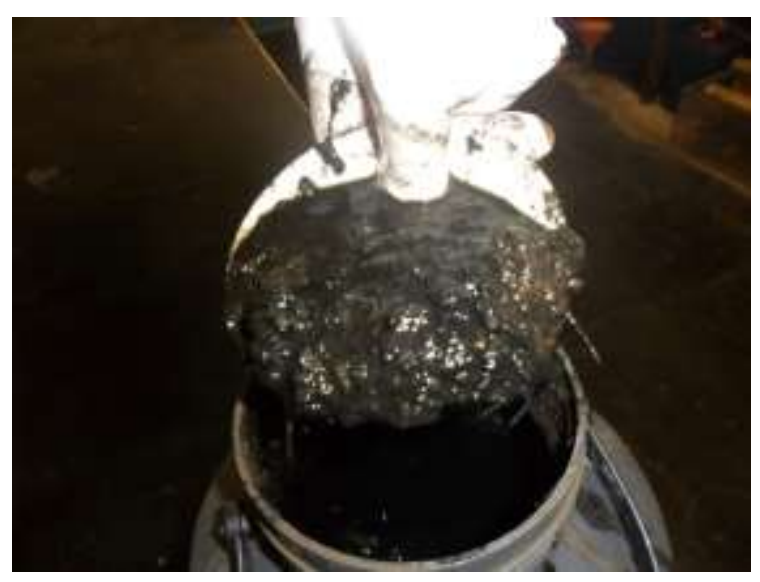

(a)

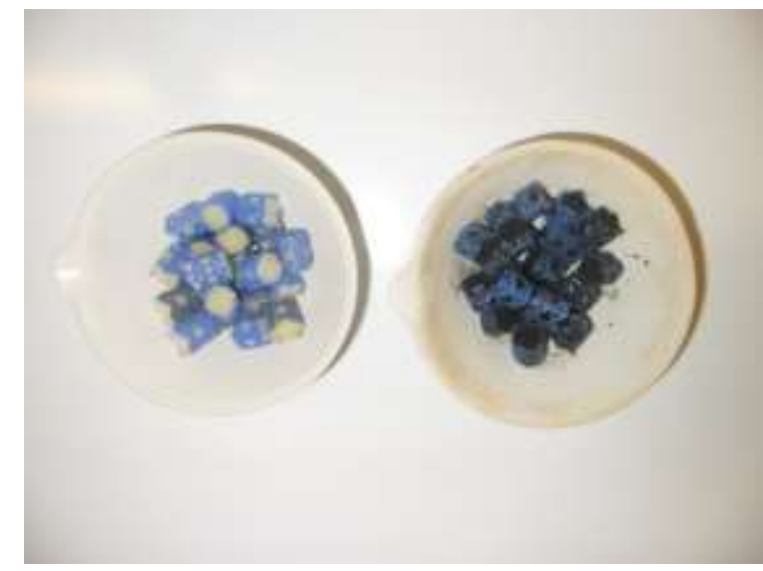

(b)

Fonte: Autor.

\subsection{O Lixiviado de Aterro Sanitário Utilizado no Experimento}

O lixiviado utilizado nesta pesquisa é proveniente do aterro sanitário que pertence ao Centro de Gerenciamento de Resíduos (CGR) da cidade de Paulínia-SP, administrado pela Estre Ambiental. O aterro sanitário, inaugurado em 1999, atende a 33 municípios e possui uma área total de $705.000 \mathrm{~m}^{2}$. A unidade recebe cerca de 500 t/dia de resíduos domiciliares e industriais, além de lodo de estações de tratamento de água e resíduos da construção civil. São produzidos em média $450 \mathrm{~m}^{3}$ 
de lixiviado por dia, que são coletados e encaminhados para a Estação de Tratamento de Esgoto (ETE) da cidade de Jundiaí (FEIJÓ, 2015).

A coleta deste lixiviado foi feita pela própria Estre, que o encaminhou até 0 Laboratório de Saneamento da EP-USP. A Tabela 18 apresenta os resultados da caracterização do lixiviado coletado em Paulínia.

Tabela 18 - Caracterização do lixiviado procedente do aterro de Paulínia-SP.

\begin{tabular}{|c|c|c|c|}
\hline Parâmetro & Unidade & Valor Médio* & Desvio Padrão \\
\hline $\mathrm{pH}$ & - & 8,11 & 0,08 \\
\hline Alcalinidade Total & $\mathrm{mg} \mathrm{CaCO}_{3} / \mathrm{L}$ & 11.997 & 921 \\
\hline DQO Filtrada & $\mathrm{mg} \mathrm{O}_{2} / \mathrm{L}$ & 3.235 & 223 \\
\hline СOT & $\mathrm{mg} \mathrm{C} / \mathrm{L}$ & 1.049 & 132 \\
\hline AVT & mg Hc.Acético/L & 1.007 & 61 \\
\hline $\mathrm{N}-\mathrm{NH}_{3}$ & $\mathrm{mg} \mathrm{N} / \mathrm{L}$ & 2.642 & 131 \\
\hline ST & $\mathrm{mg} / \mathrm{L}$ & 13.853 & 742 \\
\hline STF & $\mathrm{mg} / \mathrm{L}$ & 10.726 & 194 \\
\hline STV & $\mathrm{mg} / \mathrm{L}$ & 3.127 & 737 \\
\hline SST & $\mathrm{mg} / \mathrm{L}$ & 432 & 47 \\
\hline SSF & $\mathrm{mg} / \mathrm{L}$ & 199 & 23 \\
\hline Ssv & $\mathrm{mg} / \mathrm{L}$ & 233 & 38 \\
\hline SDT & $\mathrm{mg} / \mathrm{L}$ & 13.421 & 723 \\
\hline SDF & $\mathrm{mg} / \mathrm{L}$ & 10.526 & 196 \\
\hline SDV & $\mathrm{mg} / \mathrm{L}$ & 2.895 & 733 \\
\hline Condutividade & $\mu \mathrm{S} / \mathrm{cm}$ & 32.010 & 2.036 \\
\hline $\mathrm{Na}^{+}$ & $\mathrm{mg} / \mathrm{L}$ & 1.260 & 171 \\
\hline $\mathrm{K}^{+}$ & $\mathrm{mg} / \mathrm{L}$ & 840 & 31 \\
\hline $\mathrm{Ca}^{++}$ & $\mathrm{mg} / \mathrm{L}$ & 26 & 7 \\
\hline $\mathbf{M g}^{++}$ & $\mathrm{mg} / \mathrm{L}$ & 53 & 12 \\
\hline
\end{tabular}

* Média de três amostras; ** AVT por titulação.

\subsection{Montagem do Aparato Experimental}

O sistema proposto foi montado em dois compartimentos separados, sendo um deles um reator de resíduos e o outro, um filtro anaeróbio contendo biomassa imobilizada em um meio suporte, conforme o esquema do aparato experimental, ilustrado na Figura 23. 
Figura 23 - Esquema do aparato experimental utilizado na pesquisa com o filtro anaeróbio à esquerda e o reator de resíduos à direita (medidas $\mathrm{em} \mathrm{cm}$ ).

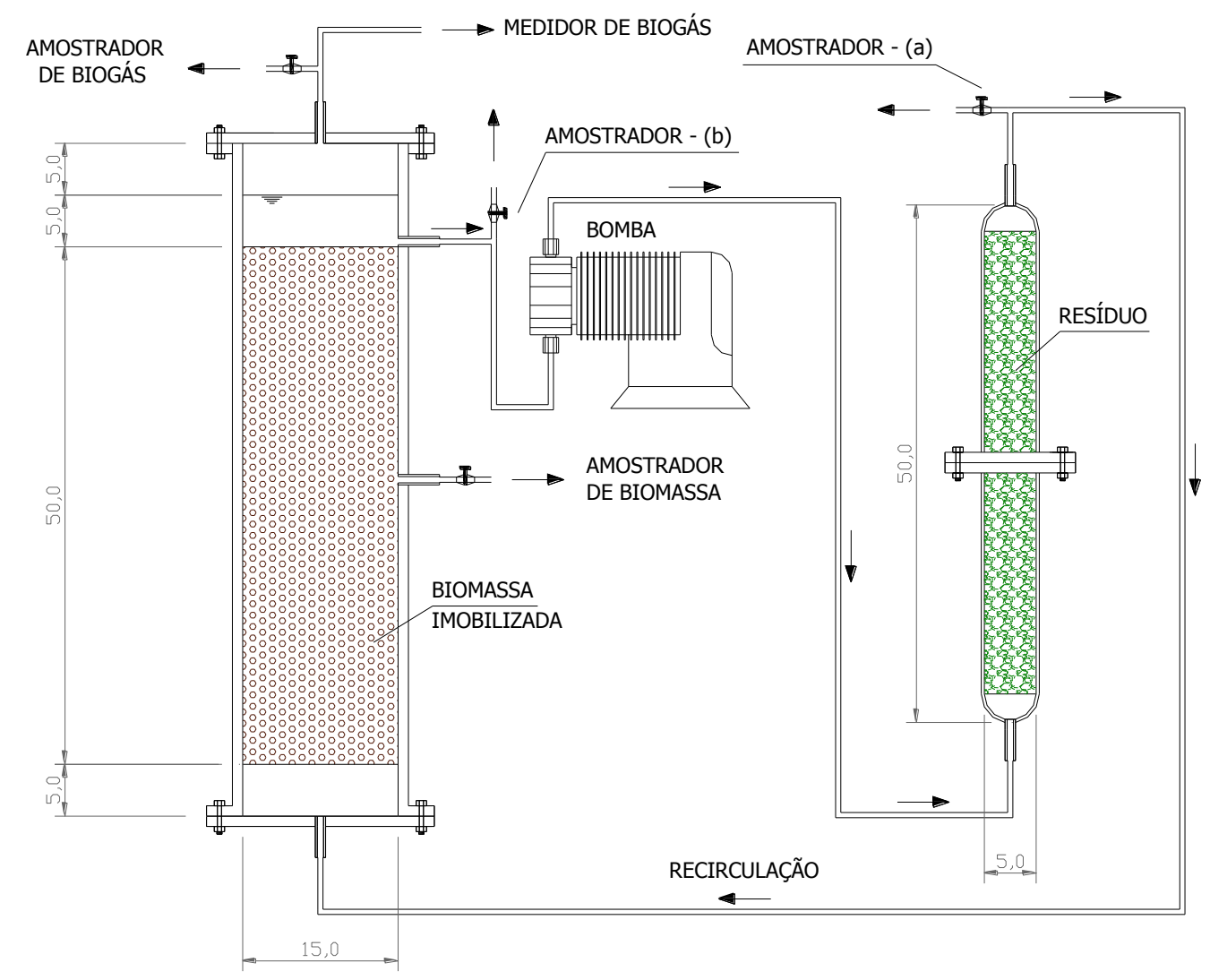

Fonte: o autor.

Para que o sistema fosse mantido em temperatura controlada de $32 \pm 2{ }^{\circ} \mathrm{C}$, ele foi montado dentro de um armário de madeira com portas, que possuía no interior uma fonte de calor (duas lâmpadas incandescentes), um sistema de circulação de ar (ventilador) e um termostato para controle da temperatura (Figura 24).

Ressalta-se que esta temperatura de $32 \pm 2{ }^{\circ} \mathrm{C}$ foi selecionada por estar dentro da faixa mesofílica e por ser possível de ser alcançada em países de clima tropical, como o Brasil, sem necessidade de aquecimento do sistema. 
Figura 24 - (a) Sistema de aquecimento e circulação de ar e (b) controlador de temperatura.

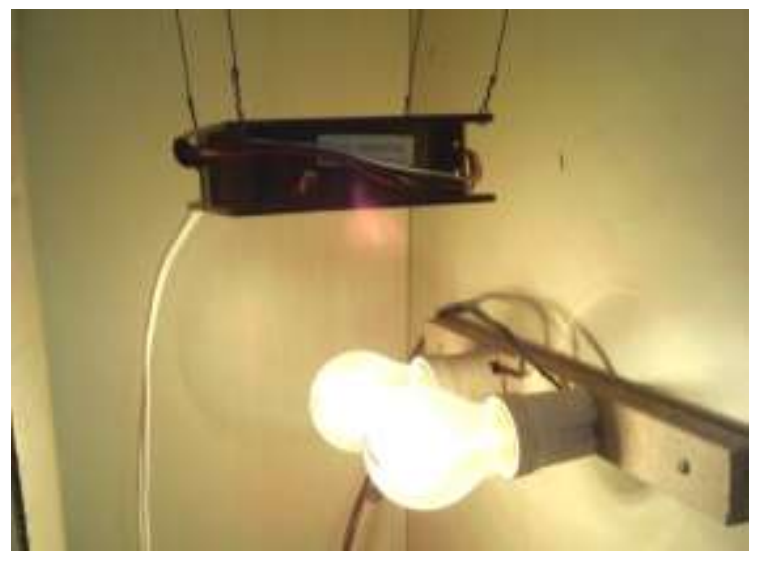

(a)

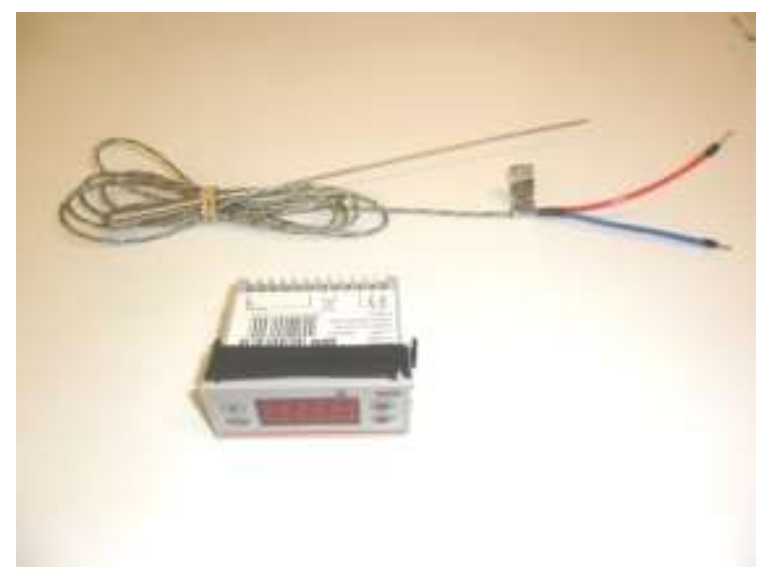

(b)

Fonte: Autor.

O reator de armazenamento dos resíduos foi confeccionado com tubos PET. Conexões de PVC nas extremidades e na parte central foram utilizadas para interligações com as mangueiras e abertura para introdução dos resíduos, respectivamente. Esse reator hidrolítico possuía volume de aproximadamente $1 \mathrm{~L}$, com formato cilíndrico, de diâmetro igual a $5,0 \mathrm{~cm}$, extremidades arredondadas e altura de aproximadamente $50 \mathrm{~cm}$, com um segmento de tubo perfurado de aproximadamente $10 \mathrm{~cm}$ na entrada inferior, que tinha por objetivo distribuir o fluxo de lixiviados na massa de resíduos (Figura 25 (a)). Próximos às extremidades de entrada e saída, existiam dois suportes com tela de náilon, sendo que o inferior estava conectado ao tubo perfurado de difusão do líquido recirculado conforme Figura 25 (b) e (c).

Foi confeccionado um saco de tela de náilon, visando a contenção do resíduo, a minimização de perdas de material e a prevenção de entupimentos. Na Figura 26, é ilustrado o saco de tela dentro e fora do reator. Acondicionado o resíduo no interior do saco de náilon, costurava-se a abertura também com um fio de náilon. 
Figura 25 - (a) Reator de resíduos, (b) suporte com tela e difusor de líquidos e (c) Suporte e difusor no interior do reator de resíduos.

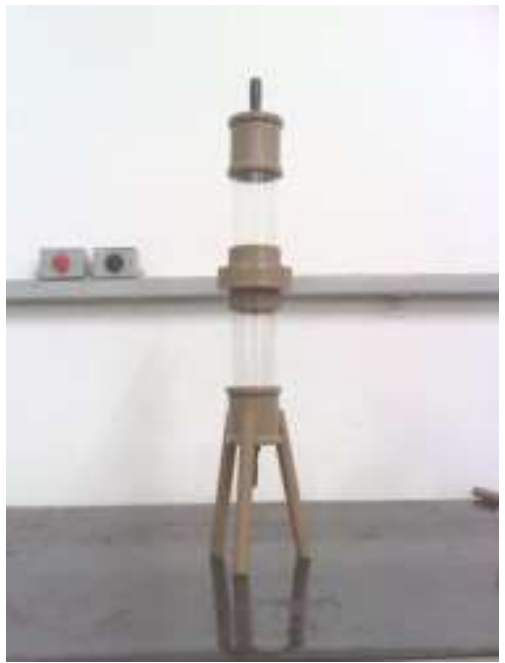

(a)

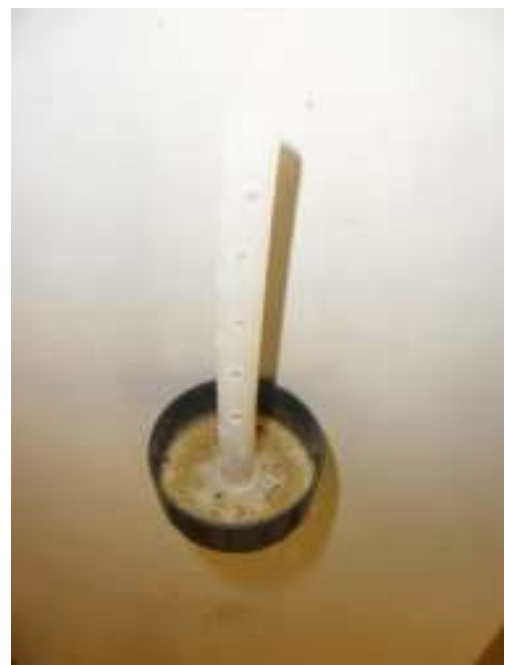

(b)

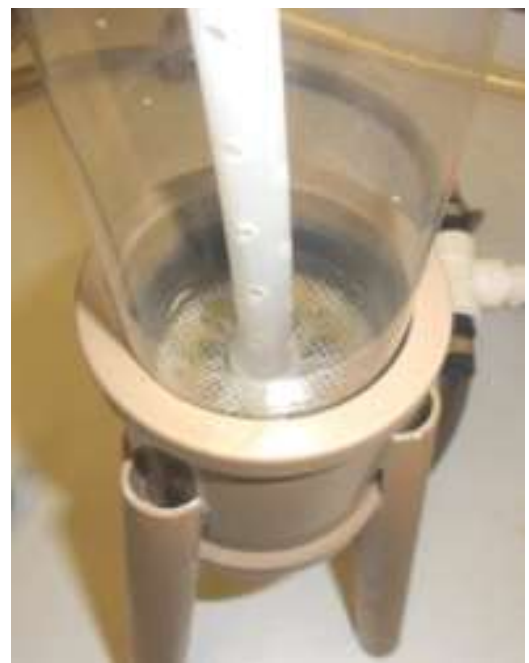

(c)

Fonte: Autor.

Figura 26 - Saco de náilon para contenção dos resíduos: (a) fora e (b) dentro do reator.

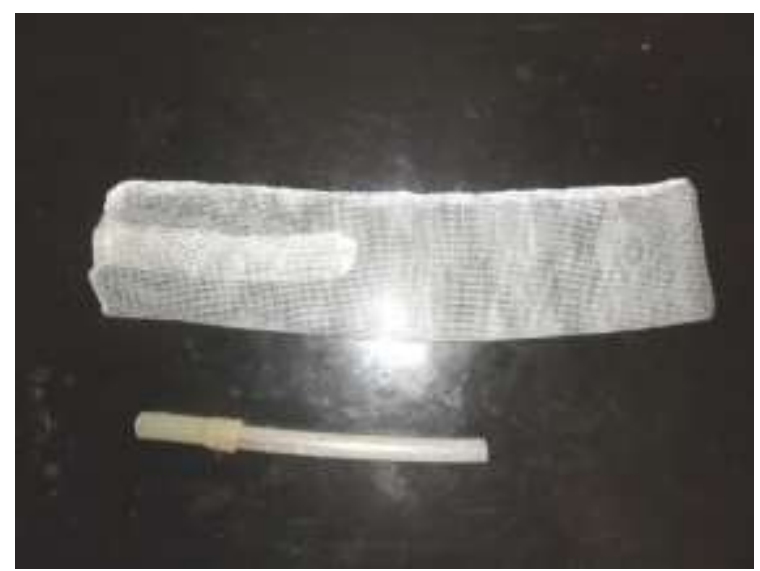

(a)

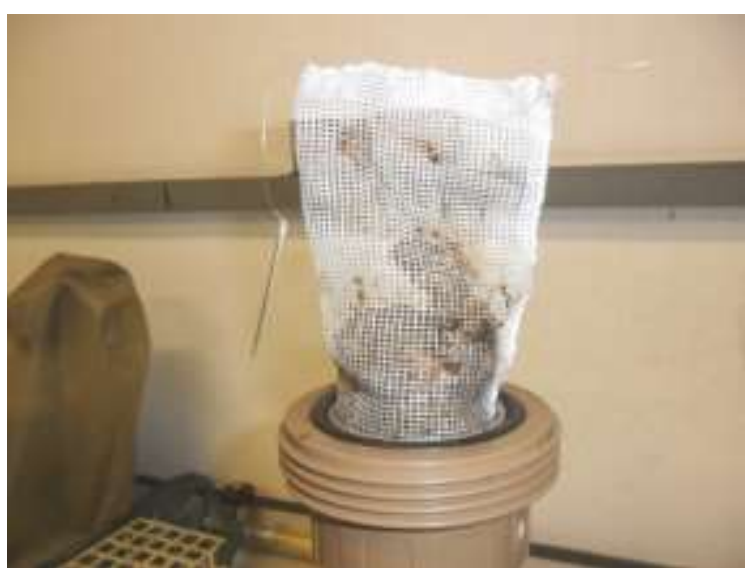

(b)

Fonte: Autor.

O filtro anaeróbio consistia de um tubo de acrílico com $15 \mathrm{~cm}$ de diâmetro interno e $65 \mathrm{~cm}$ de altura, perfazendo um volume total de aproximadamente 14,6 L. Depois que o meio suporte foi inoculado com o lodo da lagoa de lixiviado, e o excesso eliminado, ele foi introduzido no interior deste reator, a partir de uma base de aço inox perfurada, que servia de suporte, mantendo o recheio a aproximadamente 5,0 $\mathrm{cm}$ do fundo do reator, visando uma melhor distribuição do líquido de recirculação. $O$ recheio possuía aproximadamente $50,0 \mathrm{~cm}$ de altura, sendo que acima dele foi deixado mais $5,0 \mathrm{~cm}$ para acúmulo de líquido de recirculação e acima do líquido, mais 5,0 cm para separação do biogás, conforme é ilustrado na Figura 27 (b). 
Figura 27 - Meio suporte no interior do filtro anaeróbio.

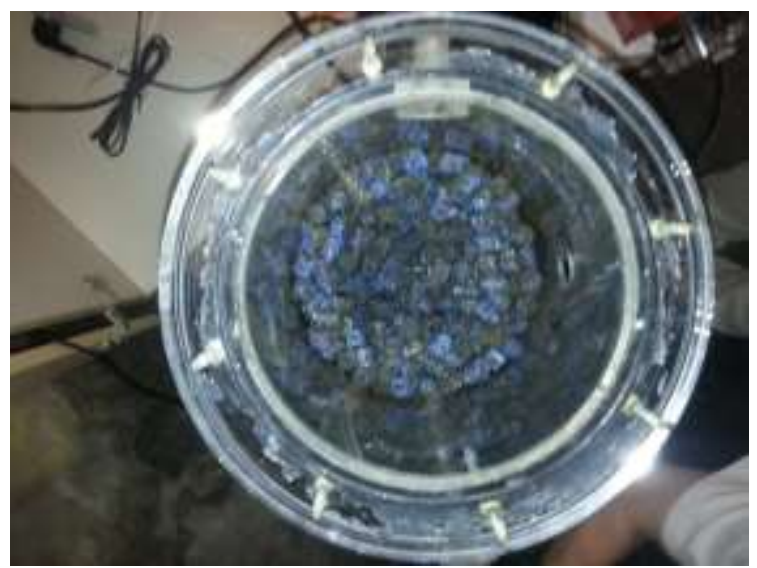

(a) vista interna

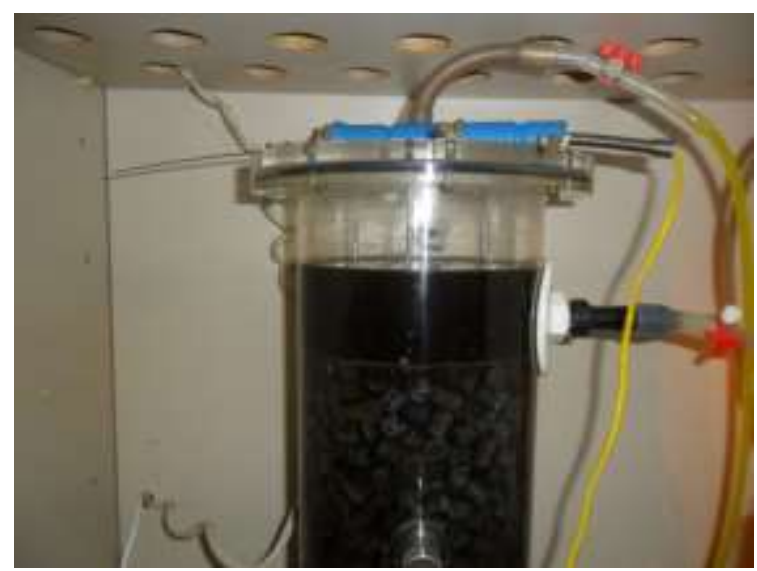

(b) lateral do reator

Fonte: Autor.

Em ambos os reatores, o fluxo era ascensional para auxiliar na liberação do biogás gerado, conforme ilustrado no esquema da Figura 23. A bomba utilizada para recirculação dos líquidos era do tipo diafragma, marca Prominent, com capacidade de vazão entre $1 \mathrm{~L} / \mathrm{h}$ e $32 \mathrm{~L} / \mathrm{h}$, que bombeava da parte superior do filtro anaeróbio para a inferior do reator de resíduos.

A medição do volume gerado de biogás foi realizada com um frasco de Mariotte, que foi confeccionado com uma garrafa de água com capacidade de $10 \mathrm{~L}$. Na Figura 28, são ilustrados a bomba de recirculação de líquidos e o frasco de Mariotte utilizados, e na

Figura 29 pode-se visualizar o sistema completo, instalado dentro do armário com controle de temperatura e aferição através de um termômetro digital, que possuía um termopar do tipo $\mathrm{K}$ instalado no centro do filtro anaeróbio.

A concentração diária de metano no biogás foi determinada de forma aproximada, por meio da reação do dióxido de carbono em hidróxido de sódio concentrado (Figura 28c), pois a Escola Politécnica não possui equipamento para este tipo de determinação. Assim, para se aferir a precisão e validade da metodologia, uma amostra foi coletada durante a batelada 14 e levada imediatamente para 0 Laboratório de Processos Anaeróbios (LPB) da Escola de Engenharia de São Carlos, utilizando-se uma ampola de vidro vedada. 
Figura 28 - (a) Bomba de recirculação de líquidos, (b) Frasco de Mariotte e (c) Fração de $\mathrm{CH}_{4}$ estimada por reação do $\mathrm{CO}_{2} \mathrm{com} \mathrm{NaOH}$.

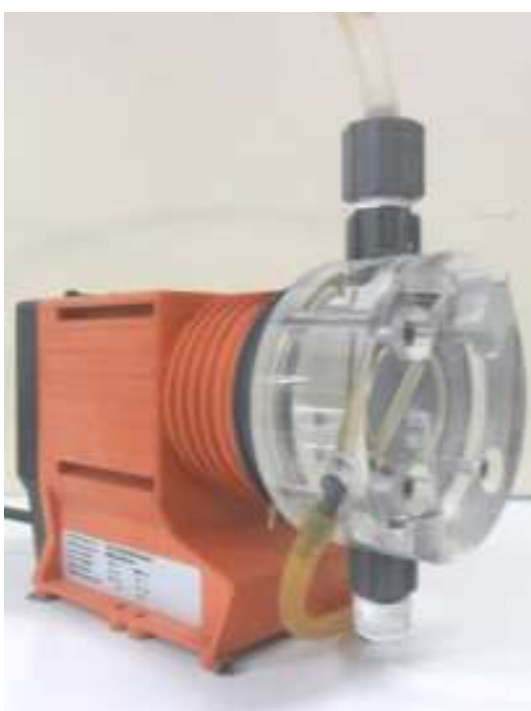

(a)

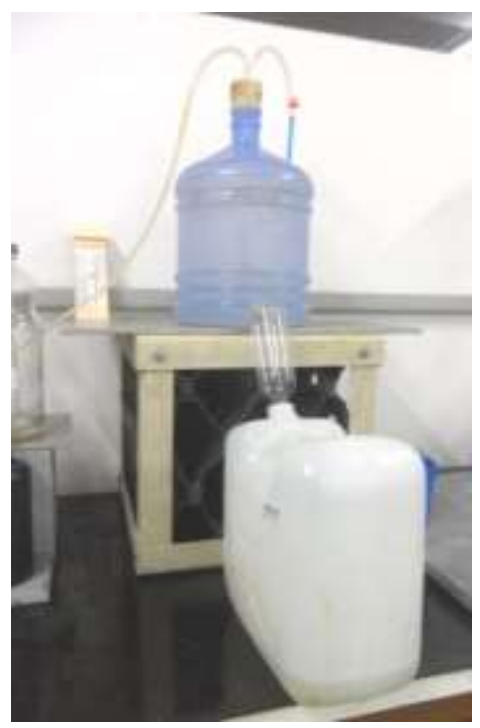

(b)

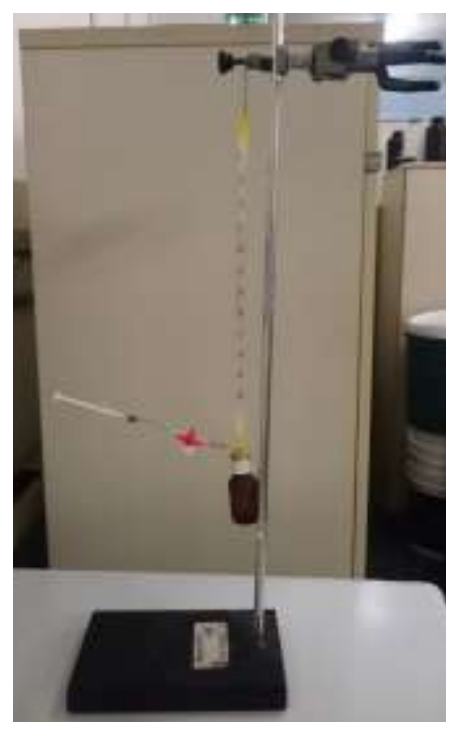

(c)

Fonte: Autor.

Figura 29 - Montagem completa do aparto experimental dentro do armário com controle de temperatura.

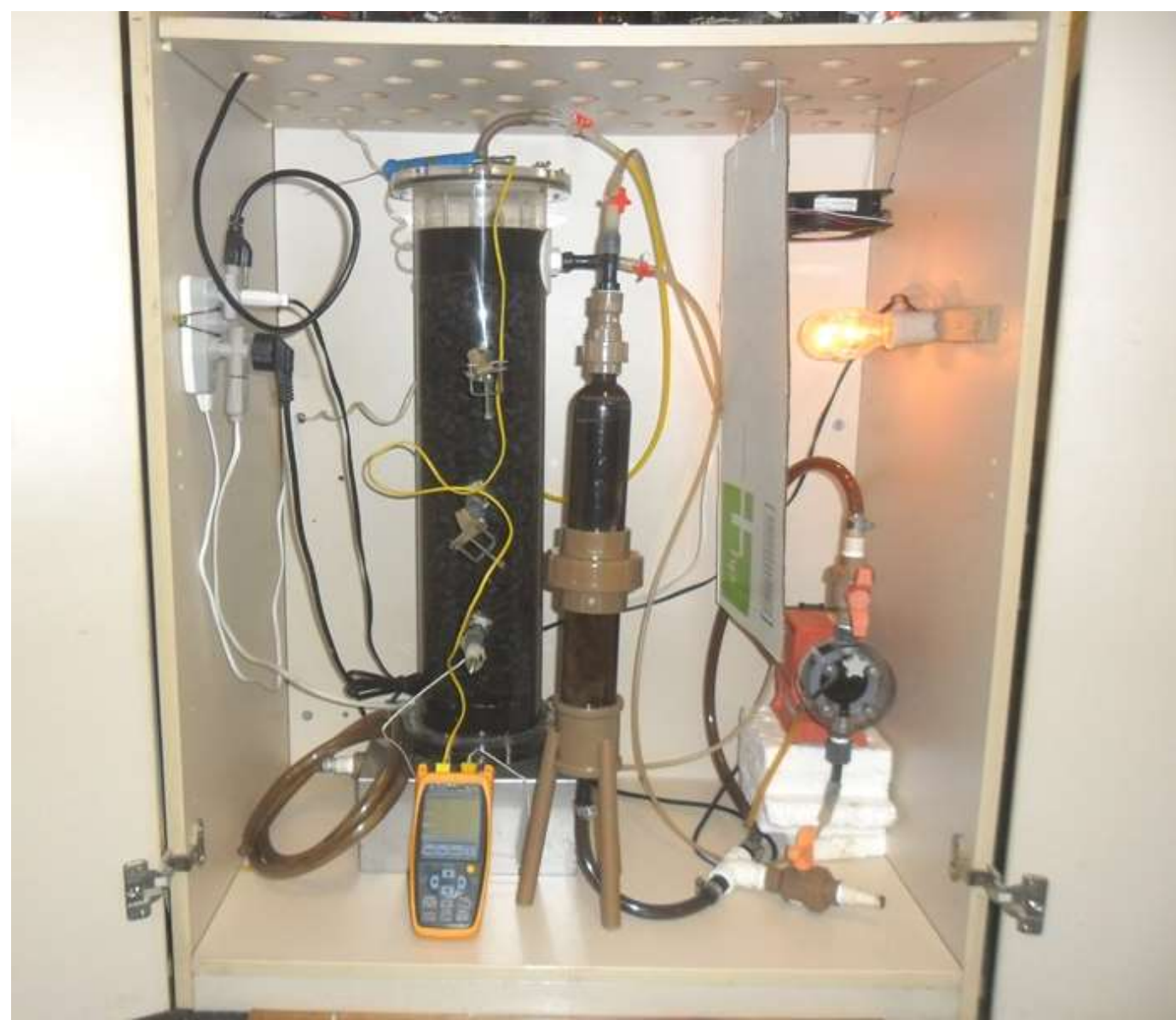

Fonte: o autor. 


\subsection{Operação do Sistema}

O experimento foi dividido em duas etapas, sendo a primeira de adaptação da biomassa ao lixiviado e definição de parâmetros operacionais básicos por meio de uma batelada teste, e a segunda composta por outras 4 fases, que compuseram propriamente o experimento.

$\mathrm{Na}$ fase de adaptação da biomassa, foi adicionado, semanalmente, etanol ao lixiviado, na quantidade de $3 \mathrm{~mL}$ por litro de lixiviado, conforme recomendado por Contrera (2008). Nessas condições, o sistema demorou cerca de um mês para iniciar uma geração considerável de biogás e mais dois meses para estabilizar-se. Nesta fase foi realizado somente 0 acompanhamento com relação à geração de biogás.

Verificada a adaptação completa da biomassa ao lixiviado, procedeu-se ao inicio de uma batelada teste, realizada à temperatura ambiente (média $\sim 27^{\circ} \mathrm{C}$ ), chamada neste experimento de "batelada zero", onde o sistema foi alimentado com resíduo sólido. Por meio desta batelada, foram definidos o tempo de reação máximo e um protocolo de amostragem dos líquidos de recirculação e gases gerados, que é ilustrado na Tabela 19.

Tabela 19 - Amostragens de líquidos e gases ao longo das bateladas.

\begin{tabular}{|c|c|c|c|c|c|c|c|c|c|c|c|c|c|c|c|c|c|c|c|c|c|}
\hline \multirow[b]{2}{*}{$\begin{array}{l}\text { Tipo de } \\
\text { Amostra }\end{array}$} & \multicolumn{21}{|c|}{ Pontos de amostragem ao longo da batelada [dias] } \\
\hline & 0 & 1 & 2 & 3 & 4 & 5 & 6 & $\begin{array}{l}7 \\
a \\
8\end{array}$ & 9 & $\begin{array}{c}10 \\
a \\
11\end{array}$ & 12 & $\begin{array}{c}13 \\
a \\
16\end{array}$ & 17 & $\begin{array}{c}18 \\
a \\
21\end{array}$ & 22 & $\begin{array}{c}23 \\
a \\
26\end{array}$ & 27 & $\begin{array}{c}28 \\
a \\
31\end{array}$ & 32 & $\begin{array}{c}33 \\
a \\
36\end{array}$ & 37 \\
\hline Líquida & $X$ & $X$ & $X$ & $X$ & $X$ & & $X$ & & $X$ & & $X$ & & $\mathrm{X}$ & & $X$ & & $\mathrm{X}$ & & $\mathrm{X}$ & & $X$ \\
\hline Gasosa & $X$ & $X$ & $X$ & $X$ & $x$ & $X$ & $X$ & $X$ & $X$ & $X$ & $x$ & $X$ & $X$ & $X$ & $X$ & $X$ & $X$ & $X$ & $X$ & $X$ & $X$ \\
\hline
\end{tabular}

Ao se iniciar a operação do sistema com resíduos, a duração de cada batelada foi variável até que o sistema atingisse baixa produção de gás $(<1,0 \%$ do volume acumulado até aquele momento) e essa produção coincidisse com um dos pontos de amostragem ilustrados na Tabela 19. O volume de lixiviado introduzido a cada batelada no sistema foi de aproximadamente $6,7 \mathrm{~L}$.

Assim que foi verificada a estabilidade operacional do sistema, por meio da aproximação das curvas de produção de biogás, foi também verificado o efeito da variação da taxa de recirculação de líquidos, aumentando-a de aproximadamente 12 
para 24 ciclos por dia, com pelo menos três repetições (bateladas) para cada taxa de recirculação pesquisada. Adicionalmente, verificou-se também, a operação do sistema sem aquecimento, ou seja, à temperatura ambiente, numa faixa de $25 \pm 2^{\circ} \mathrm{C}$.

Dessa forma, após a batelada zero, iniciou-se a segunda etapa experimental que foi dividida em quatro fases, conforme mostra a Tabela 20 , sendo a primeira, de Adaptação, que compreendeu as bateladas 01 a 04, onde os tempos de reação foram variáveis iniciando-se com 37 dias e reduzindo-o até se chegar aos 22 dias na batelada 04 . Nesta fase, o sistema foi operado a aproximadamente $32^{\circ} \mathrm{C}$ com taxas de recirculação de líquidos iguais a 12 ciclos por dia.

Após a fase de adaptação, iniciou-se a Fase 01, onde foram mantidas as mesmas condições operacionais da fase anterior. Esta fase compreendeu as bateladas $04 \mathrm{a}$ 06, sendo a 04 considerada uma batelada comum entre as fases de adaptação e a 01, pois nessa batelada ocorreu o último ajuste de tempo de reação. Na Fase 02, a velocidade de recirculação foi duplicada para 24 ciclos por dia, mantendo-se a mesma temperatura operacional e compreendeu as bateladas 07 a 10 e a batelada 13.

Na prática, em países de climas tropicais é possível a operação de biodigestores à temperatura ambiente (sem aquecimento), assim, foi realizada a Fase 03, onde se manteve a taxa de recirculação de líquidos em 24 ciclos por dia e a temperatura operacional em aproximadamente $25^{\circ} \mathrm{C}$.

Tabela 20 - 2ª Etapa experimental: fases de operação do sistema e condições experimentais.

\begin{tabular}{|c|c|c|c|c|c|c|c|c|c|c|c|c|c|c|}
\hline \multirow{2}{*}{ Fase } & \multicolumn{14}{|c|}{ Batelada } \\
\hline & 01 & 02 & 03 & 04 & 05 & 06 & 07 & 08 & 09 & 10 & 11 & 12 & 13 & 14 \\
\hline Adaptação & $\begin{array}{l}32^{\circ} \mathrm{C} \\
12 \mathrm{X} \\
37 \mathrm{~d}\end{array}$ & $\begin{array}{l}32^{\circ} \mathrm{C} \\
12 \mathrm{X} \\
32 \mathrm{~d}\end{array}$ & $\begin{array}{l}32^{\circ} \mathrm{C} \\
12 \mathrm{X} \\
27 \mathrm{~d}\end{array}$ & $\begin{array}{l}32^{\circ} \mathrm{C} \\
12 \mathrm{X} \\
22 \mathrm{~d}\end{array}$ & & & & & & & & & & \\
\hline 01 & & & & $\begin{array}{l}32{ }^{\circ} \mathrm{C} \\
12 \mathrm{X} \\
22 \mathrm{~d}\end{array}$ & $\begin{array}{l}32^{\circ} \mathrm{C} \\
12 \mathrm{X} \\
22 \mathrm{~d}\end{array}$ & $\begin{array}{l}32^{\circ} \mathrm{C} \\
12 \mathrm{X} \\
22 \mathrm{~d}\end{array}$ & & & & & & & & \\
\hline 02 & & & & & & & $\begin{array}{l}32^{\circ} \mathrm{C} \\
24 \mathrm{X} \\
22 \mathrm{~d}\end{array}$ & $\begin{array}{l}32{ }^{\circ} \mathrm{C} \\
24 \mathrm{X} \\
22 \mathrm{~d}\end{array}$ & $\begin{array}{l}32{ }^{\circ} \mathrm{C} \\
24 \mathrm{X} \\
22 \mathrm{~d}\end{array}$ & $\begin{array}{l}32{ }^{\circ} \mathrm{C} \\
24 \mathrm{X} \\
22 \mathrm{~d}\end{array}$ & & & $\begin{array}{l}32{ }^{\circ} \mathrm{C} \\
24 \mathrm{X} \\
22 \mathrm{~d}\end{array}$ & \\
\hline 03 & & & & & & & & & & & $\begin{array}{l}25{ }^{\circ} \mathrm{C} \\
24 \mathrm{X} \\
32 \mathrm{~d}\end{array}$ & $\begin{array}{l}25{ }^{\circ} \mathrm{C} \\
24 \mathrm{X} \\
32 \mathrm{~d}\end{array}$ & & $\begin{array}{l}25^{\circ} \mathrm{C} \\
24 \mathrm{X} \\
32 \mathrm{~d}\end{array}$ \\
\hline
\end{tabular}


Ressalta-se que mesmo após a realização de quatro bateladas na Fase 02 e duas outras na Fase 03, ainda restavam dúvidas a respeito da Fase 02, pois nesta as bateladas 07 e 10 tiveram comportamento ligeiramente distinto das bateladas 08 e 09, quanto à geração de biogás. Dessa forma, optou-se por realizar mais uma batelada nas condições da Fase 02 para se sanar as dúvidas. Esta verificação poderia ter sido realizada depois da última batelada da Fase 03, todavia, buscandose também observar a resposta do sistema quanto à alternância de condições, ela foi inserida entre duas bateladas da Fase 03. A batelada 13 apresentou geração de biogás próxima às das bateladas 08 e 09, e deste modo, estas foram as três bateladas selecionadas para representar a Fase 02, todavia, os resultados das gerações de biogás das batelada 07 e 10 também serão apresentados para que se possa justificar a escolha realizada.

O reator foi operado em bateladas sequenciais, obedecendo ao seguinte procedimento:

1) Colocava-se o saco de náilon dentro do reator de resíduo e com o auxilio de um funil, preenchia-se o mesmo com a amostra e costurava-se a abertura superior. Fechava-se o reator através de uma conexão central de PVC (junta de união com rosca de $60 \mathrm{~mm})$;

2) O reator de resíduos era conectado ao filtro anaeróbio e ao sistema de recirculação através de conexões de PVC (duas juntas de união com rosca de 25 $\mathrm{mm}$ cada);

3) Abria-se para atmosfera a saída de gases do filtro anaeróbio;

4) Iniciava-se o enchimento manual do filtro anaeróbio com o líquido, por uma entrada em sua extremidade inferior, através de um funil e mangueira, até que fosse alcançado o nível máximo;

5) Ligava-se a bomba de recirculação, que transferia o líquido da parte superior do filtro anaeróbio para o reator de resíduos, com o objetivo de saturar a massa de resíduos e eliminar o ar de dentro deste reator e das mangueiras;

6) Completava-se novamente o filtro anaeróbio até se atingir o nível máximo;

7) Fechava-se a entrada inferior de líquido e drenava-se a mangueira de alimentação; 
8) Conectava-se a saída de biogás ao frasco de Mariotte e iniciava-se a batelada;

9) Durante o período de reação, fez-se o monitoramento do sistema através de medições diárias da produção de gás, do pH e da temperatura;

10) Chegando-se ao tempo de detenção estimado para batelada, de acordo com a escala prevista, ela era considerada finalizada.

11) Abria-se a saída de biogás para entrada de ar atmosférico, evitando-se o sifonamento de líquido do Mariotte para dentro do filtro anaeróbio;

12) Drenavam-se ambos os reatores;

13) Retirava-se a amostra digerida de matéria orgânica do reator de resíduos para sua caracterização.

Como a composição dos resíduos sólidos a serem tratados nas diversas bateladas pode ser considerada constante, conforme a Tabela 17, houve somente uma caracterização, que serviu como referência para todas as bateladas. Entretanto, os resíduos tratados recuperados ao final de cada batelada foram caracterizados.

Com relação à biomassa anaeróbia aderida no sistema, foram realizadas duas amostragens no meio suporte. A primeira delas foi realizada antes da batelada $01 \mathrm{e}$ foi composta por 3 amostras compostas de 10 unidades de meio suporte ("bob"+espuma), que continham biomassa das várias alturas do leito do reator. Ao final do experimento, o mesmo procedimento foi realizado, entretanto foram coletadas 5 amostras compostas de 10 unidades de meio suporte cada uma, também com biomassa coletada em várias alturas do leito do reator.

\subsection{Caracterização das Amostras}

As análises físico-químicas foram realizadas no Laboratório de Saneamento "Professor Lucas Nogueira Garcez" do Departamento de Engenharia Hidráulica e Ambiental da Escola Politécnica da Universidade de São Paulo, seguindo os métodos constantes no APHA; AWWA e WEF (2005), exceto ácidos voláteis totais (AVT). Este foi realizado de acordo com DiLallo e Albertson (1961), modificado por Contrera (2008). 
As análises de composição do biogás, de micro-organismos da biomassa (microscopia ótica) e do resíduo e de Ácidos Voláteis Totais (AVT) do líquido recirculado foram realizadas no Laboratório de Processos Biológicos (LPB) e de Saneamento, do Departamento de Hidráulica e Saneamento (SHS) da Escola de Engenharia de São Carlos (EESC) da Universidade de São Paulo.

A composição do gás gerado pelo reator foi determinada através de cromatografia gasosa, utilizando-se cromatógrafo CG/DCT (Shimadzu GC2010), com coluna Carboxen 1010 PLOT - Supelco e injeção manual, conforme Adorno e Tomito (2014).

Para a caracterização da biomassa imobilizada foram realizados exames por microscopia ótica de contraste de fase e fluorescência, utilizando-se microscópio Olympus modelo BX60-FLA, e sistema de captura de imagens Image Pro-Plus.

Adicionalmente, tanto para amostras de resíduos, quanto para amostras de biomassa, foram realizados exames de Microscopia Eletrônica de Varredura (MEV) em microscópio Quanta 600 FEG, marca FEl, equipado com espectrômetro de raios X por dispersão de energia (EDS) Quantax 400 (tecnologia SDD - Silicon Drift Detector) e software Sprit, marca Bruker. As amostras foram distribuídas em fita dupla face de carbono, recobertas com carbono e fixadas em suporte próprio para MEV. A rotina de trabalho compreendeu a coleta de imagens de elétrons secundários e foi realizada no Laboratório de Caracterização Tecnológica do Departamento de Engenharia de Minas e de Petróleo da Escola Politécnica da USP.

Para as amostras sólidas, os parâmetros Carbono Orgânico e Nitrogênio Total foram determinados por análise elementar e o Fósforo Total, por espectrometria de emissão atômica com plasma induzido ICP-OES, no Instituto de Química da USP.

As determinações dos parâmetros Carbono Orgânico Total e Nitrogênio Total no resíduo foram efetuadas utilizando o equipamento Elementar Analyzer 2400 da Perkin Elmer. A Análise Elementar consiste na oxidação completa da amostra de massa conhecida do material orgânico ou inorgânico, sob oxigênio puro, formando gases de combustão $\left(\mathrm{CO}_{2}, \mathrm{H}_{2} \mathrm{O}, \mathrm{NO}_{2}, \mathrm{~N}_{2} \mathrm{O}_{2}\right)$. A mistura desses gases passa sobre um tubo que contêm cobre metálico, que reduz os óxidos nitrosos a $\mathrm{N}_{2}$. A mistura resultante $\left(\mathrm{CO}_{2}, \mathrm{H}_{2} \mathrm{O}, \mathrm{N}_{2}\right)$ é direcionada para uma coluna cromatográfica, onde os 
compostos são separados em carbono, nitrogênio e hidrogênio e os elementos determinados através de um Detector de Condutividade Térmica.

O parâmetro Fósforo Total foi determinado utilizando-se um Espectrômetro Ótico de Emissão Atômica com Plasma Indutivamente Acoplado (ICP-OES, Radial) da marca Spectro, modelo Arcos. O procedimento para a determinação analítica consistiu na homogeneização prévia de $1 \mathrm{~g}$ da amostra em almofariz de ágata, sendo adicionados $10 \mathrm{~mL}$ de ácido nítrico concentrado e levado a aquecimento sob refluxo a $100{ }^{\circ} \mathrm{C}$ (utilizando balão de $100 \mathrm{~mL}$ e condensador) durante 3 horas. Posteriormente, foram adicionados $4,0 \mathrm{~mL}$ de peróxido de hidrogênio ( $30 \%$ volume) e levados a aquecimento por 1 hora. Após resfriamento, a solução foi filtrada e coletada em balão volumétrico de $25 \mathrm{~mL}$ e o volume completado com água deionizada Milli-Q, sendo posteriormente levada a leitura no ICP-OES.

Na Tabela 21, são listadas as variáveis que foram determinadas, bem como o tipo de amostra e a metodologia analítica empregada. De forma geral, foram analisadas as amostras do líquido de recirculação; do resíduo sólido a ser tratado; da biomassa do filtro anaeróbio e dos gases gerados. 
Tabela 21 - Variáveis determinadas, tipo de amostra e metodologia analítica utilizada na investigação experimental.

\begin{tabular}{|c|c|c|c|}
\hline Variável & Tipo de amostra & Método & Descrição \\
\hline $\mathrm{pH}$ & Líquido & $4500-\mathrm{H}^{+} \mathrm{B}$ & Potenciometria \\
\hline Alcalinidade total & Líquido & $2320 \mathrm{~B}$ & Titulometria \\
\hline Condutividade & Líquido & $2510 B$ & Eletrometria \\
\hline Temperatura & Líquido e resíduo & $2550 \mathrm{~B}$ & $\begin{array}{l}\text { Termômetro de mercúrio e } \\
\text { digital }\end{array}$ \\
\hline Série de sólidos & $\begin{array}{l}\text { Líquido, resíduo e } \\
\text { biomassa }\end{array}$ & 2540 B, D, E e G & Filtração e Gravimetria \\
\hline COT & Líquido & 5310 B e C & $\begin{array}{l}\text { Analisador de carbono por } \\
\text { oxidação térmica UV }\end{array}$ \\
\hline AVT & Líquido & $\begin{array}{l}\text { DiLallo e Albertson } \\
(1961)^{\star}\end{array}$ & Titulometria \\
\hline AVT & Líquido & $5560 \mathrm{~B}$ & Cromatografia Gasosa \\
\hline $\mathrm{Na}, \mathrm{K}, \mathrm{Ca}, \mathrm{Mg}$ & Líquido & 4110 & Cromatografia de íons \\
\hline $\mathrm{N}-\mathrm{NH}_{3}$ & Líquido & $4500-\mathrm{NH}_{3} \mathrm{~B}$ e C & Destilação e titulometria \\
\hline Fósforo total & Resíduo & ---------- & $\begin{array}{l}\text { Espectrometria de Emissão } \\
\text { Atômica com Plasma Indutivo } \\
\text { (ICP-OES) }\end{array}$ \\
\hline Percentual de metano & Gasosa & --------- & Neutralização em NaOH \\
\hline Composição biogás & Gasosa & $\begin{array}{l}\text { Adorno e Tomita } \\
\text { (2014) }\end{array}$ & Cromatografia \\
\hline Micro-organismos & Biomassa e Resíduo & --------- & Microscopia ótica e MEV \\
\hline Metais & $\begin{array}{l}\text { Líquido, resíduo e } \\
\text { Biomassa }\end{array}$ & $3030 \mathrm{~F} \mathrm{e} 3110$ & $\begin{array}{l}\text { Espectrofotometria de } \\
\text { absorção atômica }\end{array}$ \\
\hline Corgânico, $\mathrm{N}_{\text {Total }}$ & Resíduo & --------- & Análise elementar \\
\hline Volume Gasoso & Gasosa & Frasco de Mariotte & Deslocamento de líquido \\
\hline
\end{tabular}

* Modificado por Contrera (2008).

Fonte: APHA; AWWA e WEF (2005). 


\section{APRESENTAÇÃO E DISCUSSÃO DOS RESULTADOS}

A Figura 30 mostra as produções diária e acumulada de biogás ao longo do tempo na batelada zero, que foi realizada a aproximadamente $27 \stackrel{\circ}{ } \mathrm{C}$, com taxa de recirculação de 12 ciclos por dia. A partir desses resultados, foram definidos os seguintes parâmetros operacionais: tempo inicial de reação, intervalos de amostragem e número máximo de amostragens.

Figura 30 - Produção de biogás da batelada zero: (a) Diária e (b) Acumulada.

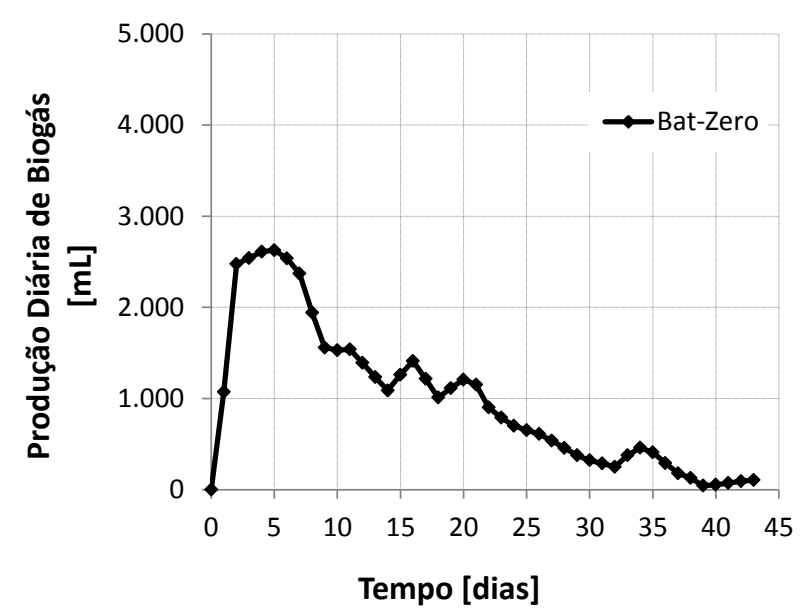

(a)

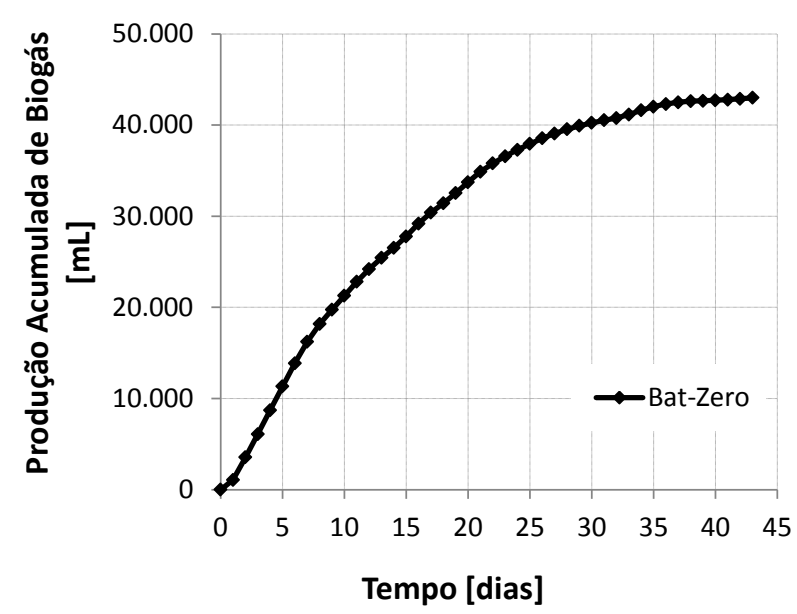

(b)

Embora na segunda etapa experimental, o sistema tenha sido operado em quatro fases distintas, a apresentação e a discussão dos resultados dessas fases serão realizadas em conjunto, de acordo com: o controle da temperatura, a geração de biogás, as características do líquido de recirculação, os resíduos sólidos tratados, e a biomassa anaeróbia.

\subsection{Controle da Temperatura}

Sabendo-se que variações de temperatura afetam a digestão anaeróbia, procurouse manter a mesma dentro de duas faixas mesofílicas: $32 \pm 2{ }^{\circ} \mathrm{C}$ e $25 \pm 2{ }^{\circ} \mathrm{C}$. Da Figura 31 (a) à Figura 31 (f), são apresentadas as medidas de temperatura no líquido interno do reator, ao longo do tempo nas quatro fases operacionais da segunda etapa. 
Figura 31 - Temperaturas operacionais nas diferentes fases do experimento.

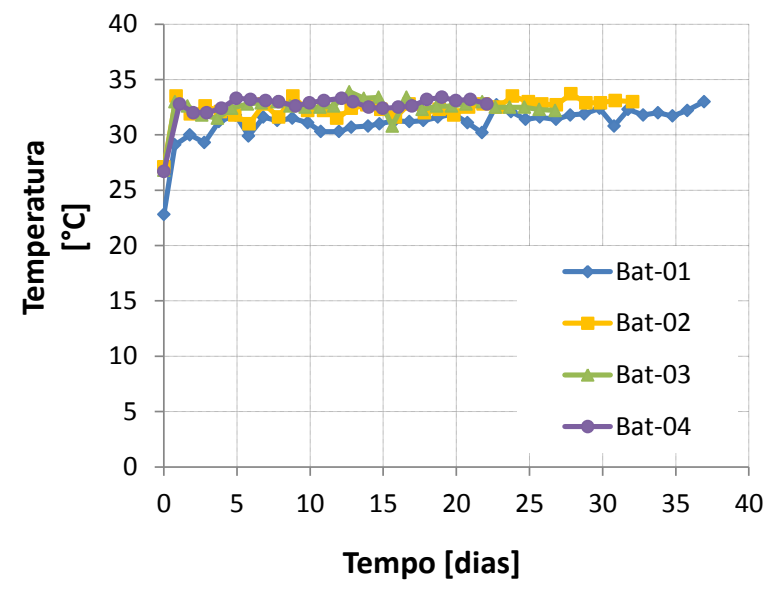

(a) Na fase de adaptação

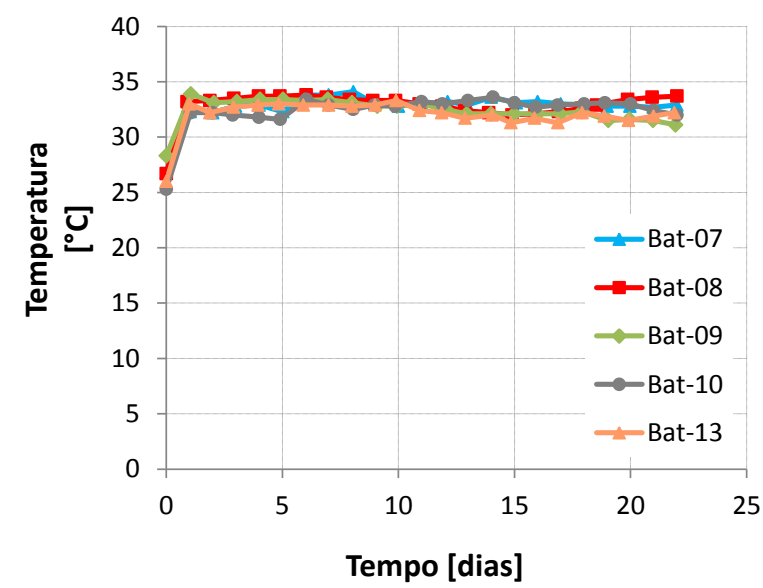

(c) ) Na Fase 2 a 24 ciclos por dia a $32^{\circ} \mathrm{C}$ com todas as bateladas

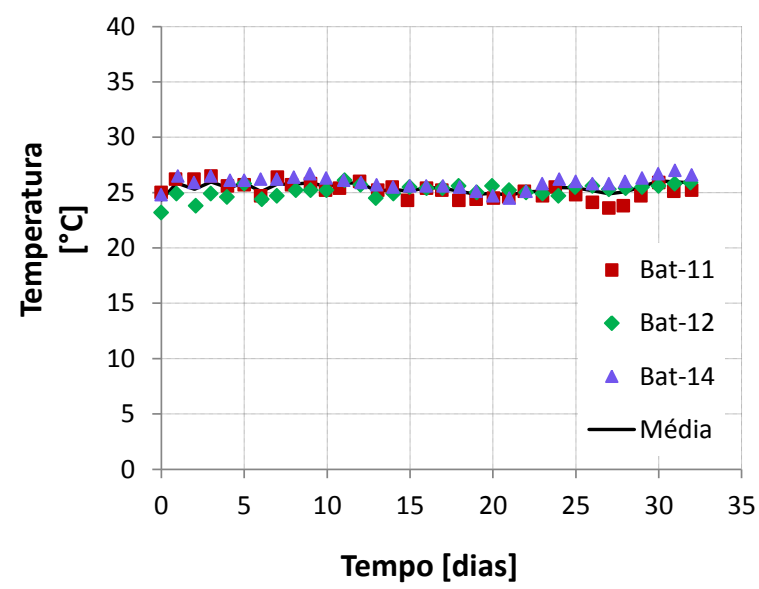

(e) Na Fase 3 a 24 ciclos por dia a $25^{\circ} \mathrm{C}$

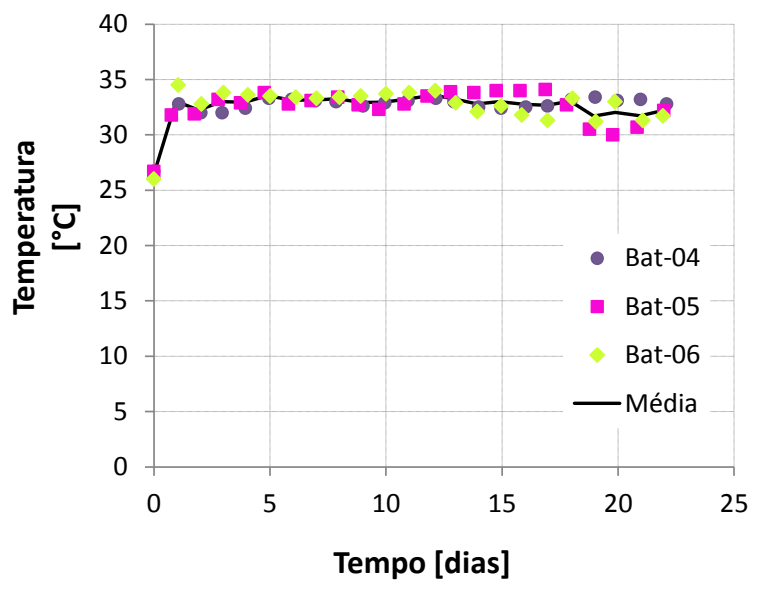

(b) Na Fase 1 a 12 ciclos por dia a $32^{\circ} \mathrm{C}$

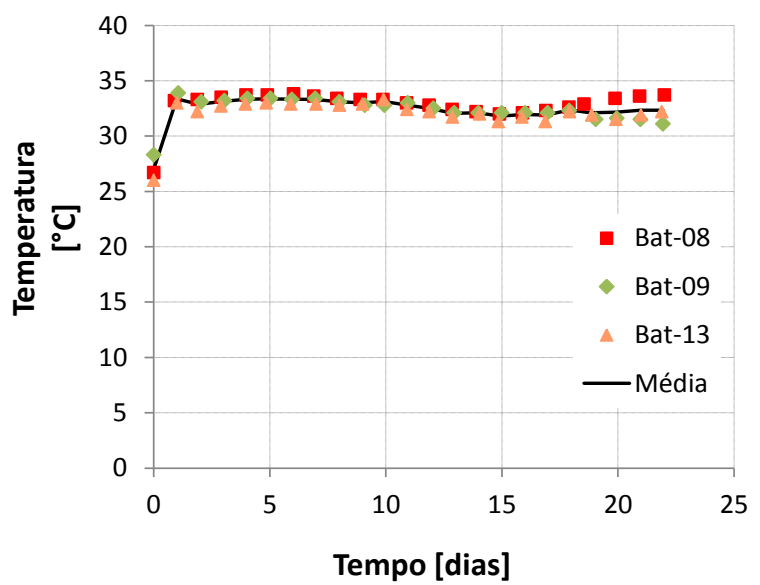

(d) Na Fase 3 a 24 ciclos por dia a $32^{\circ} \mathrm{C}$ com as bateladas selecionadas

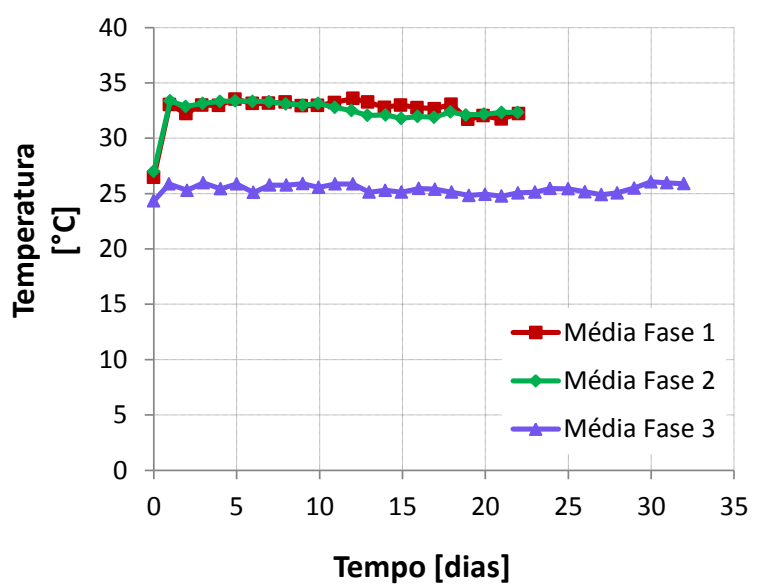

(f) Comparação entre as médias das Fases 1, 2 e 3

Destaca-se a Figura 31(f), que ilustra as temperaturas médias das Fases 01, 02 e 03, na qual é possível notar que, apesar das pequenas variações, pôde-se operar o 
sistema bem próximo das faixas desejadas. No início de cada batelada das Fases de Adaptação 01 e 02, o sistema se encontrava aproximadamente à temperatura ambiente e demorava cerca de um a dois dias para se estabilizar na faixa de temperatura desejada $\left(32 \pm 2{ }^{\circ} \mathrm{C}\right)$.

\subsection{Geração de Biogás}

O principal parâmetro de controle operacional do sistema foi a produção de biogás, sendo sua variação ao longo do tempo mostrada da Figura 32 à Figura 35 . Ao se observar a produção de biogás das bateladas, de acordo com o planejamento experimental, procurou-se responder às seguintes questões: 1) Quantas bateladas seriam necessárias para a adaptação do sistema e a otimização do tempo de reação? 2) Ao se reduzir a temperatura operacional do sistema para uma próxima à ambiente, qual seria a redução na produção de biogás? 3) Aumentando-se a taxa de recirculação de líquidos, a taxa de produção diária de biogás e o volume total de biogás produzido seriam aumentados? 4) Como variou a proporção de metano no biogás? 5) Seria mais vantajoso operar o sistema à temperatura ambiente, ou utilizar parte do biogás gerado para aquecimento do sistema?

A análise dos resultados das produções acumuladas de biogás nas primeiras quatro bateladas permite que a primeira questão seja respondida. Na Figura 32 (a) é possível se notar uma aproximação sucessiva das curvas entre si, entretanto, como existem variações entre as produções totais de biogás, a normalização dessas curvas (Figura 33 (a)) permite inferir que as produções percentuais de biogás praticamente se sobrepõem nas bateladas 02 a 04, com estabilização da produção acumulada a partir de 22 dias. Assim, esta contínua adaptação permitiu a redução dos tempos de reação, mantendo-se praticamente a mesma produção de biogás, indicando que tempos de reação relativamente curtos podem ser utilizados em projetos de digestores anaeróbios operados nestas condições.

Ao se comparar os tempos de reação de outros sistemas de mesma natureza (batelada), apresentados na Tabela 15, que variam de 28 a 47 dias, nota-se que os mesmos são superiores aos 22 dias utilizados nessa pesquisa. 
Figura 32 - Produções acumuladas de biogás nas diferentes fases do experimento.

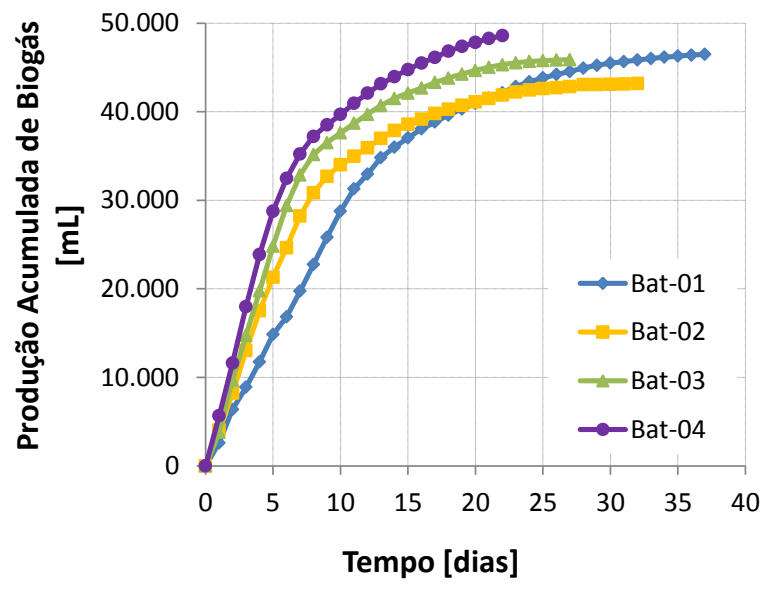

(a) Na fase de adaptação

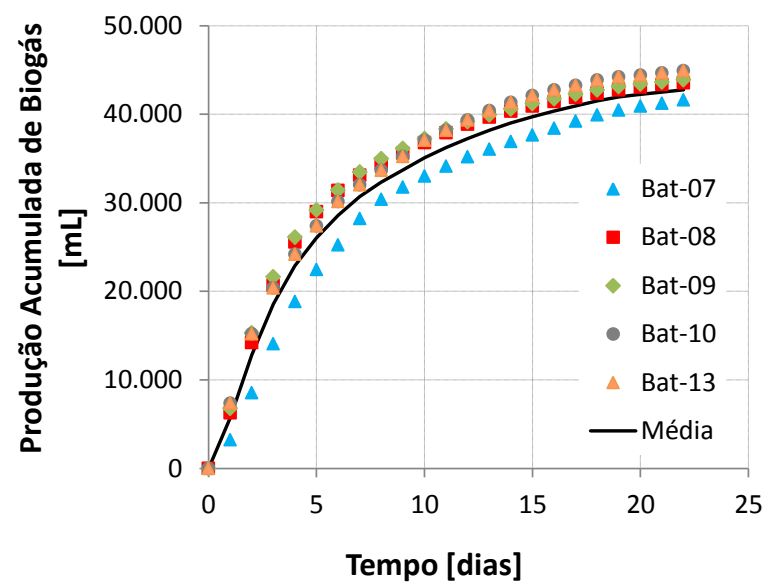

(c) Na Fase 2 a 24 ciclos por dia e $32^{\circ} \mathrm{C}$ com todas as bateladas

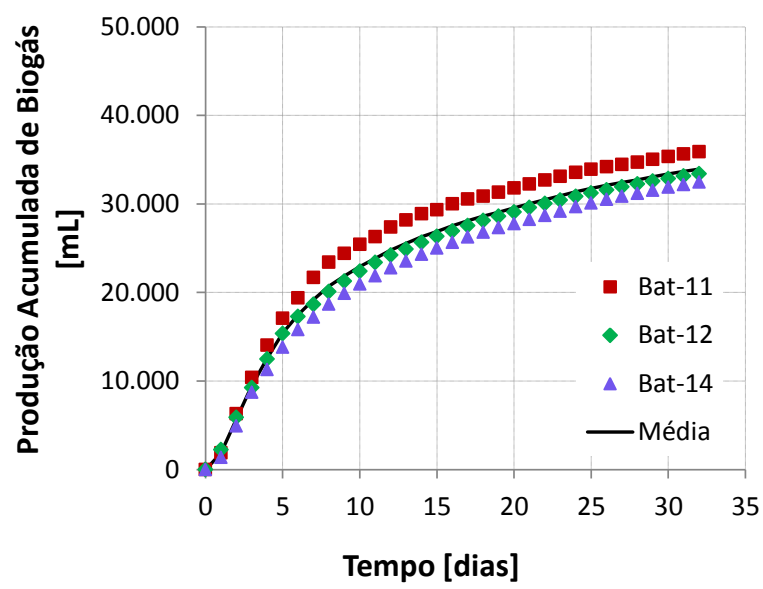

(e) Na Fase 3 a 24 ciclos por dia e $25^{\circ} \mathrm{C}$

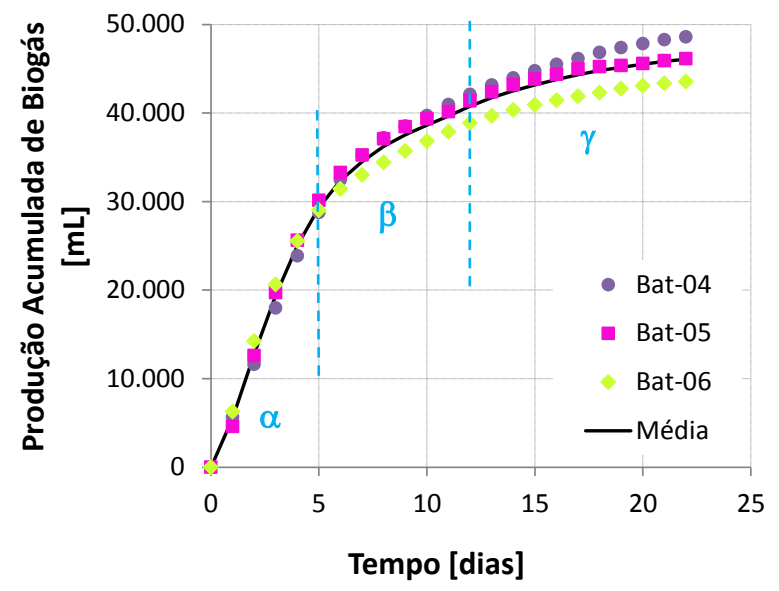

(b) Na Fase 1 a 12 ciclos por dia e $32^{\circ} \mathrm{C}$

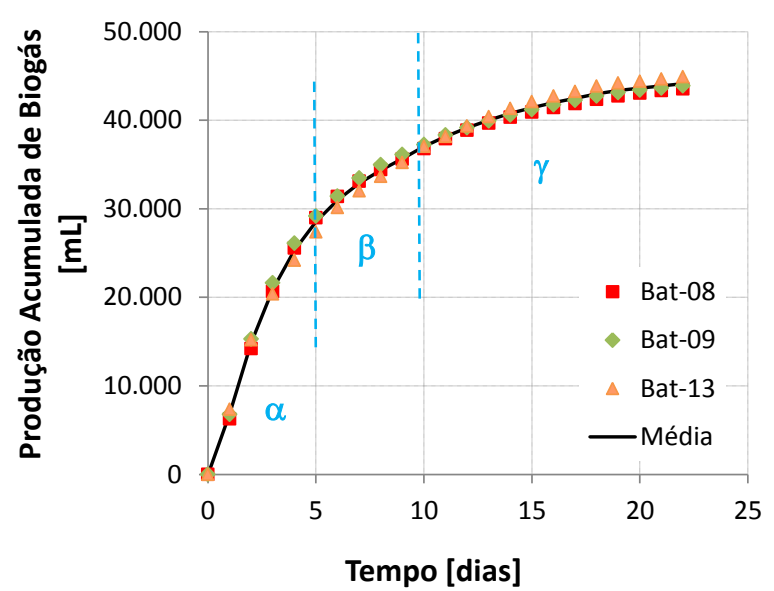

(d) Na Fase 2 a 24 ciclos por dia e $32^{\circ} \mathrm{C}$ com as bateladas selecionadas

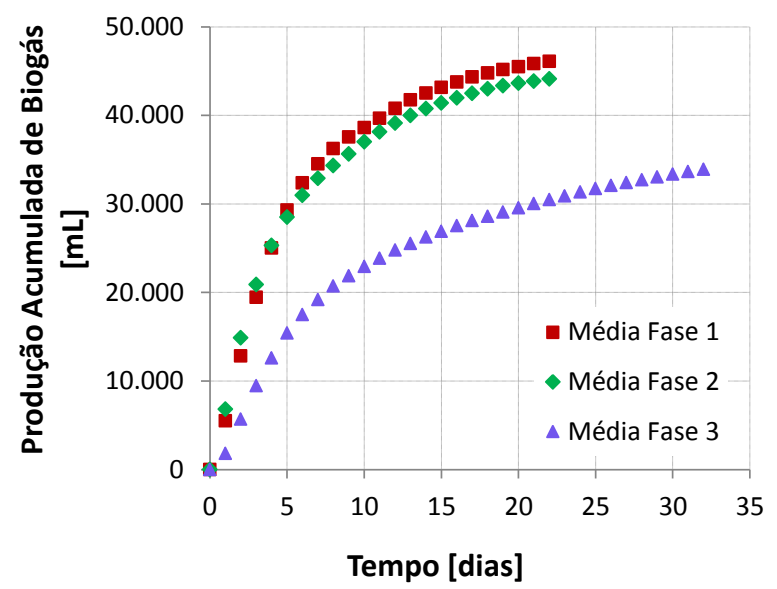

(f) Comparação entre as médias das Fases 1, 2 e 3 
Figura 33 - Produções percentuais acumuladas de biogás nas diferentes fases do experimento.

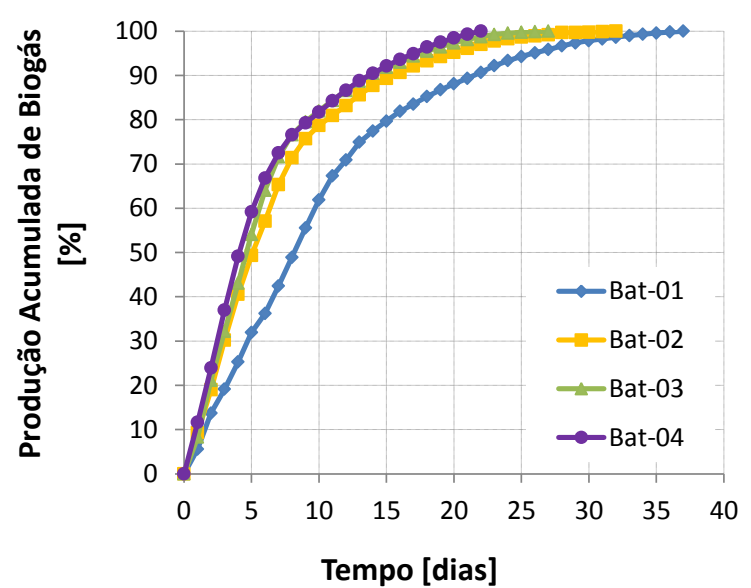

(a) Na fase de adaptação

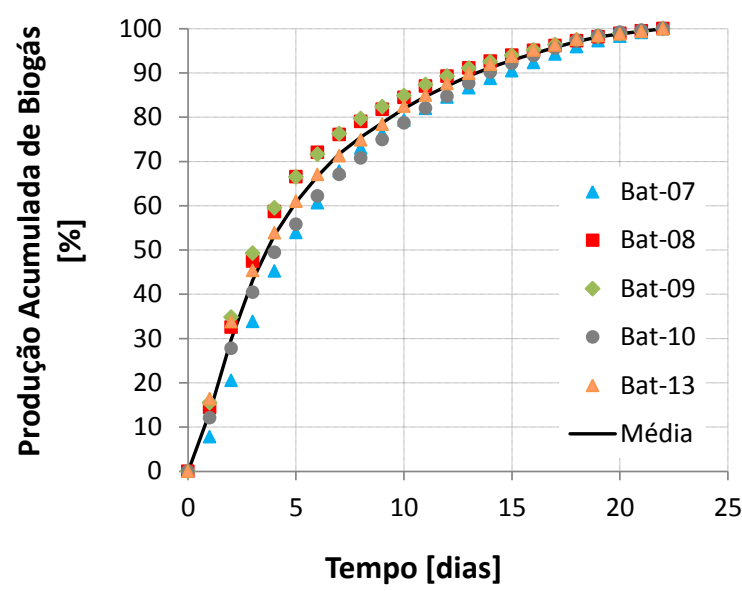

(c) Na Fase 2 a 24 ciclos por dia e $32^{\circ} \mathrm{C}$ com todas as bateladas

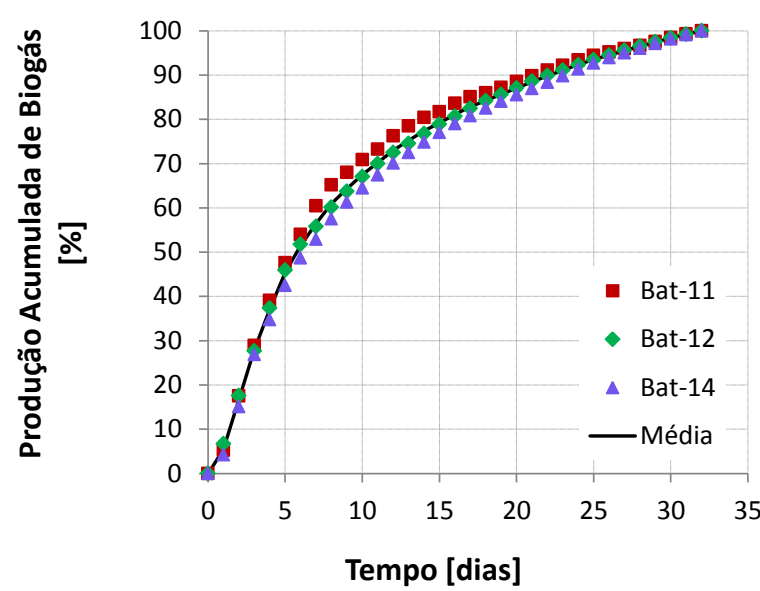

(e) Na Fase 3 a 24 ciclos por dia e $25^{\circ} \mathrm{C}$

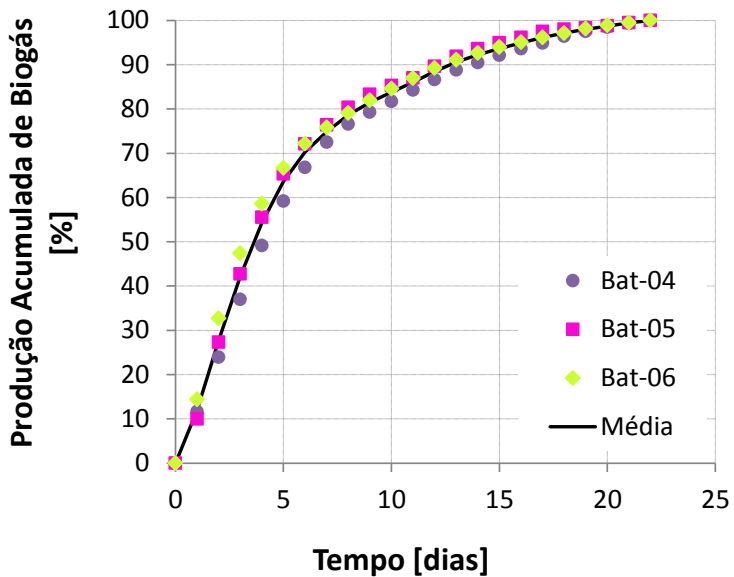

(b) Na Fase 1 a 12 ciclos por dia e $32^{\circ} \mathrm{C}$

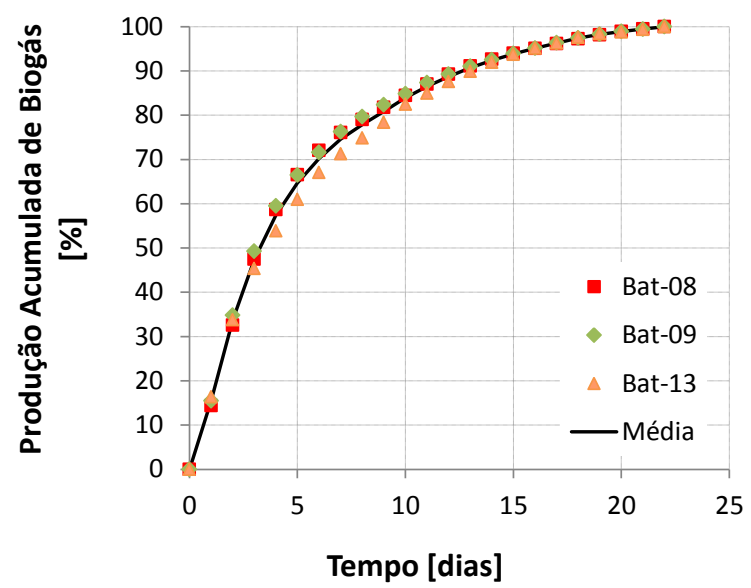

(d) Na Fase 2 a 24 ciclos por dia e $32^{\circ} \mathrm{C}$ com as bateladas selecionadas

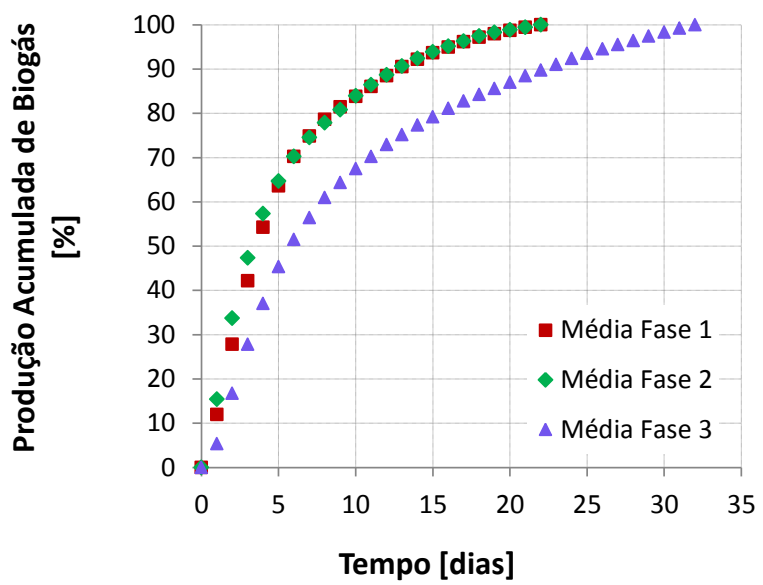

(f) Comparação entre as médias das Fases 1, 2 e 3 
Por meio da Figura 33 é possível observar que, para as Fases 01 e 02, aos 15 dias de operação, todas as bateladas já haviam produzido mais de 90\% (média 42,3 L) da geração total de biogás (média 45,1 L). Contudo, na Fase 03, além da menor produção total de biogás (média 33,9 L), somente após 23 dias de operação, este valor superou 90\% da geração total (média 30,9 L), o que em termos práticos representa um acréscimo nos tempos de reação e consequentemente um aumento considerável do volume das unidades de tratamento.

Salienta-se que na Fase 03, Figura 32 (e) e (f), devido à temperatura operacional mais baixa $\left(25^{\circ} \mathrm{C}\right)$, mesmo aumentando-se o tempo de reação para 32 dias, a produção de biogás não atingiu as alcançadas na Fase 01 e 02 (redução média de $24,8 \%$ ). Ao se considerar um tempo comum de reação, de 22 dias, essa diferença passou a ser de $32,4 \%$, ou seja, houve uma redução de aproximadamente um terço do volume de biogás produzido, o que responde a segunda questão.

Ao se comparar os resultados das Fases 01 e 02, onde houve um aumento da taxa de recirculação de líquidos de 12 para 24 ciclos por dia, Figura 32 (b) e (d), notamse igualmente três regiões distintas de produção acumulada de biogás. A primeira, na qual a produção varia linearmente com o tempo, ocorre entre o início da batelada e $05^{\circ}$ dia (região $\alpha$ ), caracterizada pela existência de matéria orgânica de fácil biodegradação em excesso para os micro-organismos. Do $5^{\circ}$ dia ao $12^{\circ}$ ou $10^{\circ}$ dia, respectivamente, nas Fases 01 e 02, nota-se uma região de transição (região $\beta$ ), na qual se observa uma mudança acentuada de declividade, provavelmente devido ao início do esgotamento da fração orgânica facilmente biodegradável e, por fim, uma terceira região (região $\gamma$ ), caracterizada por uma declividade bem menor (digestão mais lenta) que a do primeiro trecho, provavelmente devido à metabolização de compostos complexos ou mesmo devido a uma possível inibição dos subprodutos da biodegradação (FERNÁNDEZ, PORRIER, CHAMY, 2001).

Tanto na Figura 34 quanto na Figura 35, observa-se uma descontinuidade na tendência de produção diária de biogás nas Fases 01 e 02, que ocorreram respectivamente no $12^{\circ}$ e $10^{\circ}$ dias de operação, provavelmente devido ao esgotamento da matéria orgânica facilmente biodegradável, o que não foi observado na Fase 03. 
Figura 34 - Produções diárias de biogás nas diferentes fases do experimento.

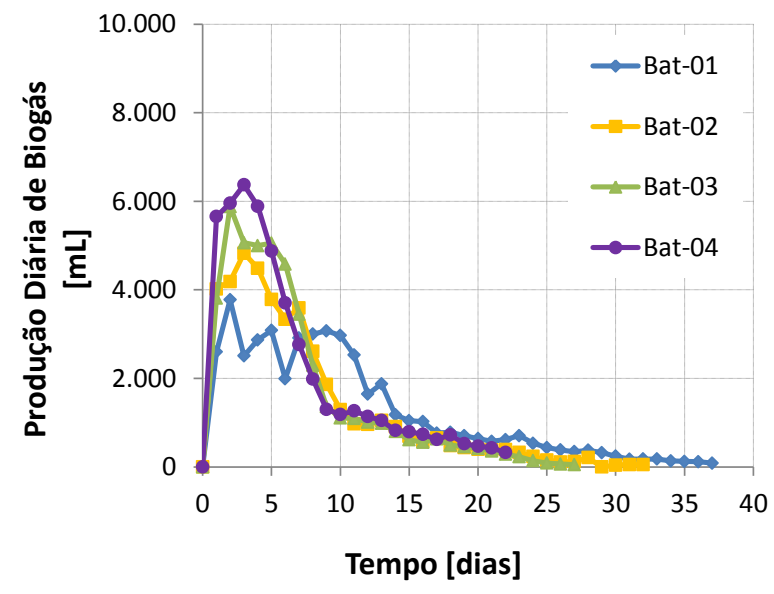

(a) Na fase de adaptação

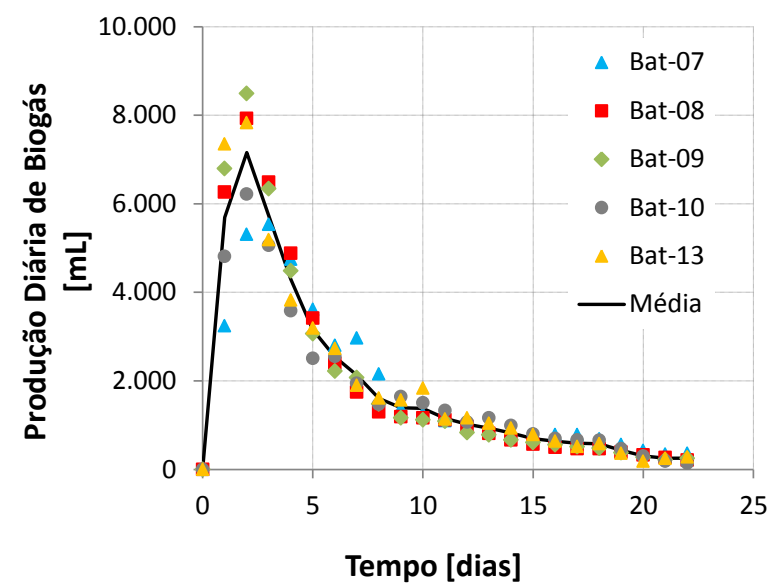

(c) Na Fase 2 a 24 ciclos por dia e $32^{\circ} \mathrm{C}$ com todas

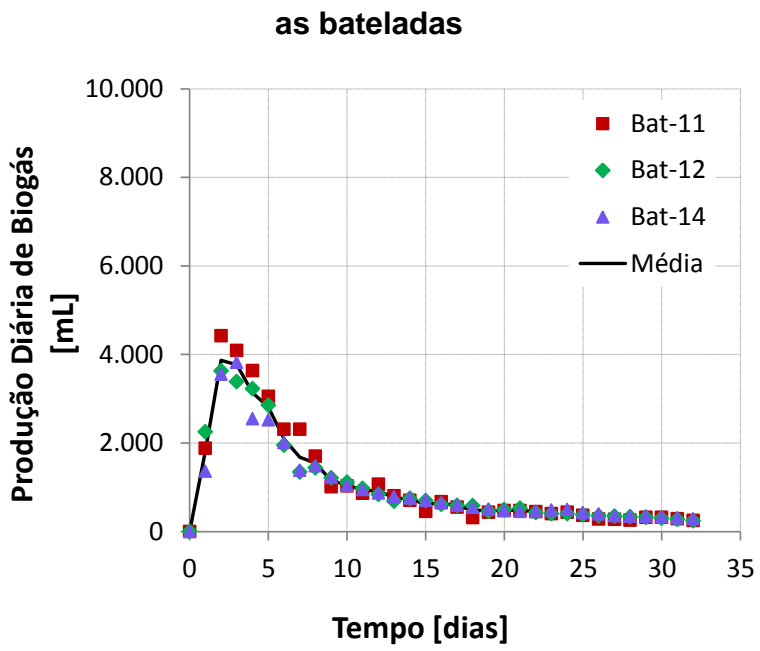

(e) Na Fase 3 a 24 ciclos por dia e $25^{\circ} \mathrm{C}$

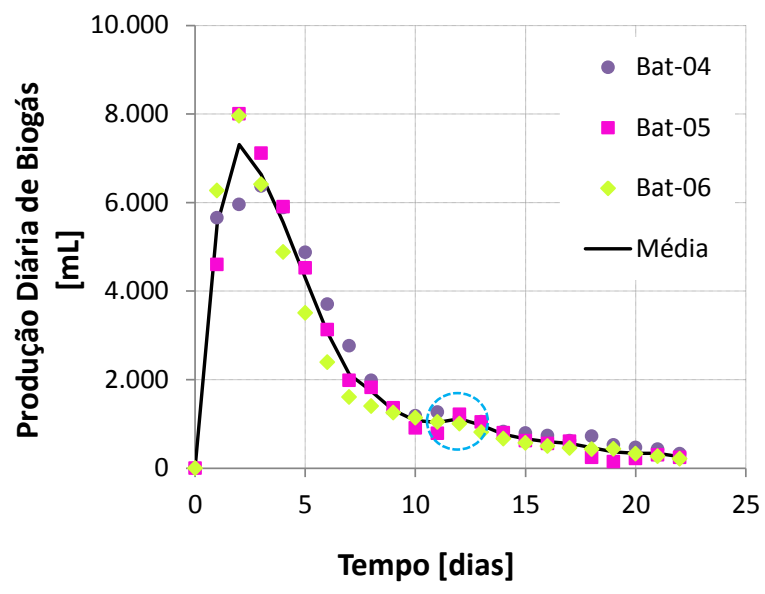

(b) Na Fase 1 a 12 ciclos por dia e $32^{\circ} \mathrm{C}$

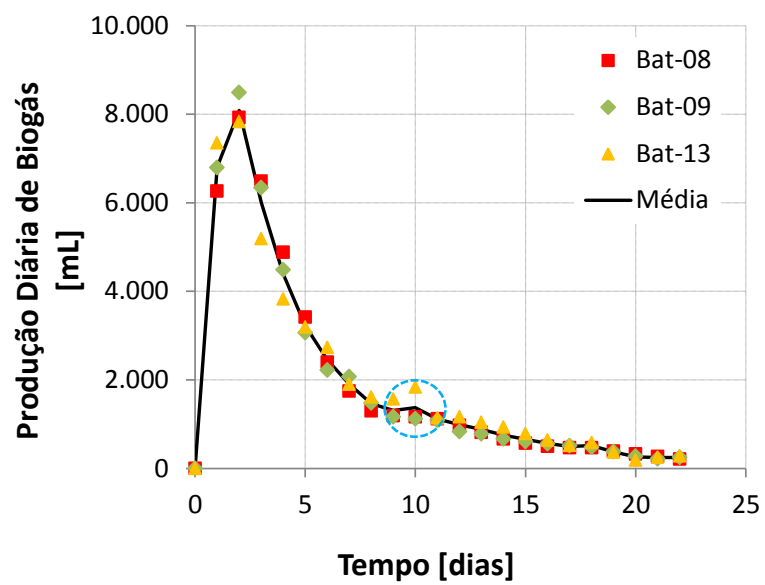

(d) Na Fase 2 a 24 ciclos por dia e $32^{\circ} \mathrm{C}$ com as bateladas selecionadas

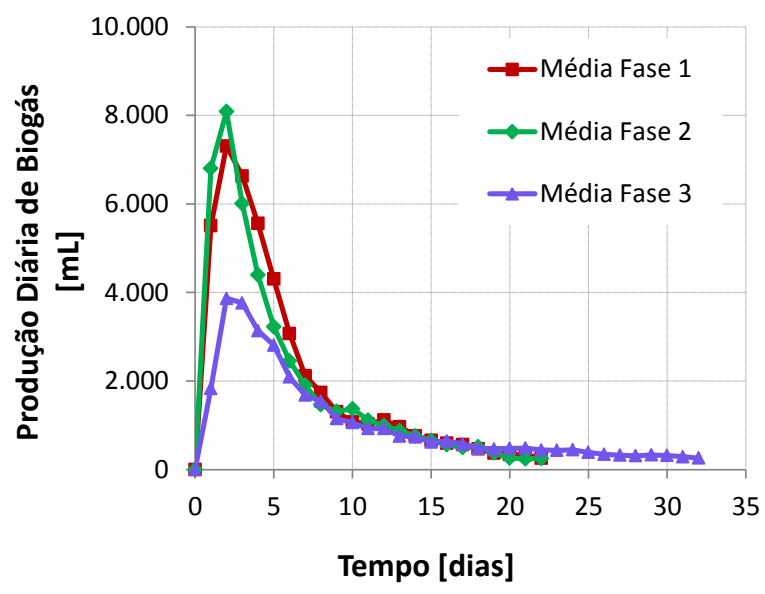

(f) Comparação entre as médias das Fases 1, 2 e 3. 
Figura 35 - Produções diárias de biogás com base nas concentrações iniciais de STV nas diferentes fases do experimento.

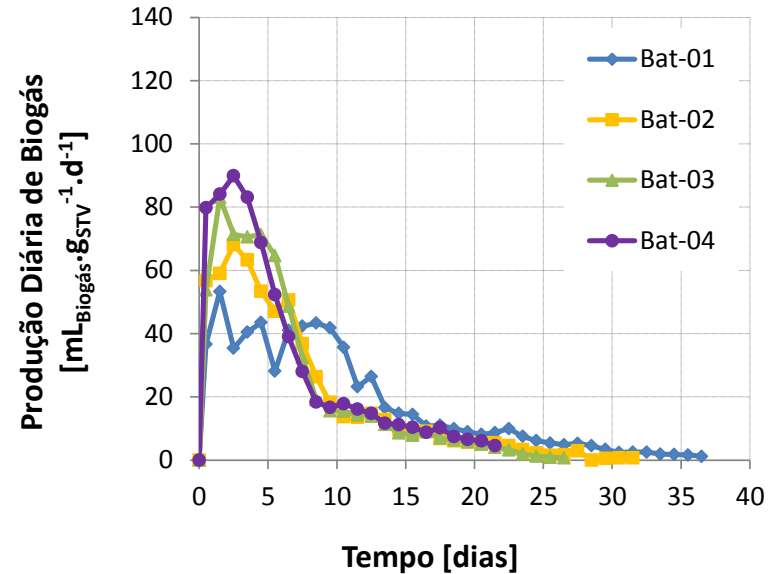

(a) Na fase de adaptação

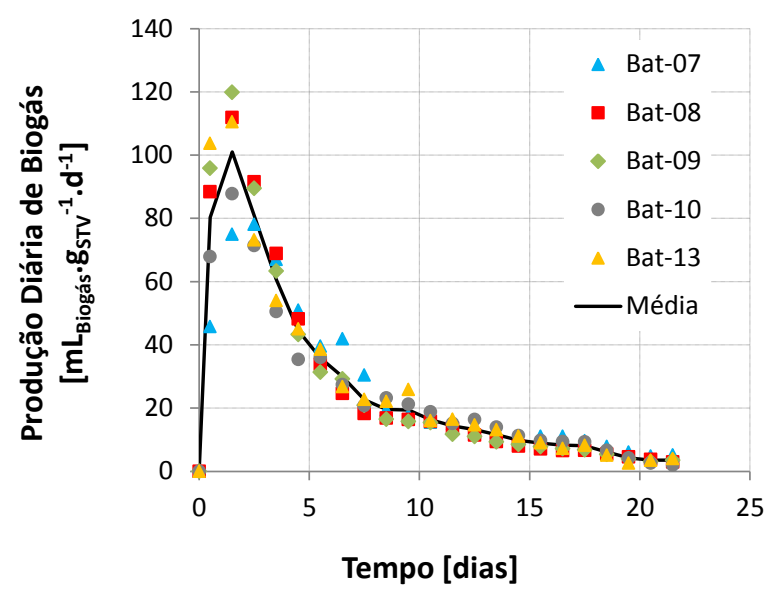

(c) Na Fase 2 a 24 ciclos por dia e $32^{\circ} \mathrm{C}$ com todas as bateladas

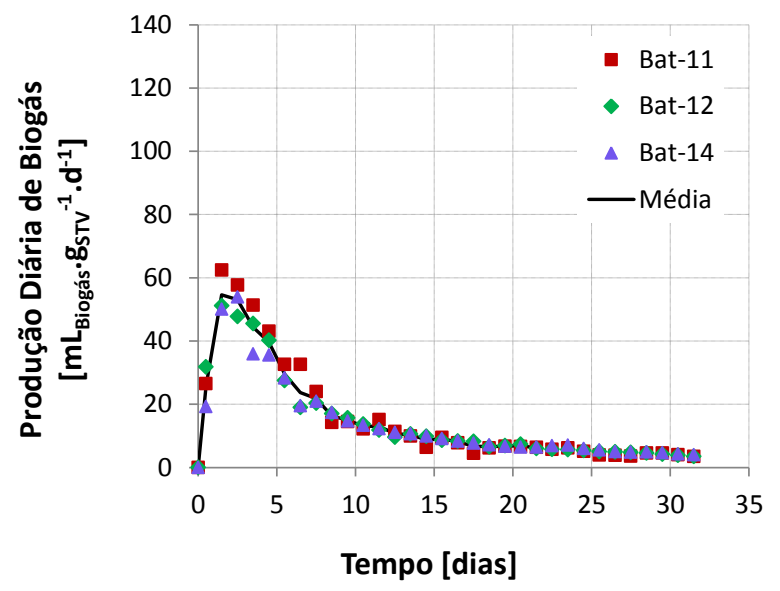

(e) Na Fase 3 a 24 ciclos por dia e $25^{\circ} \mathrm{C}$

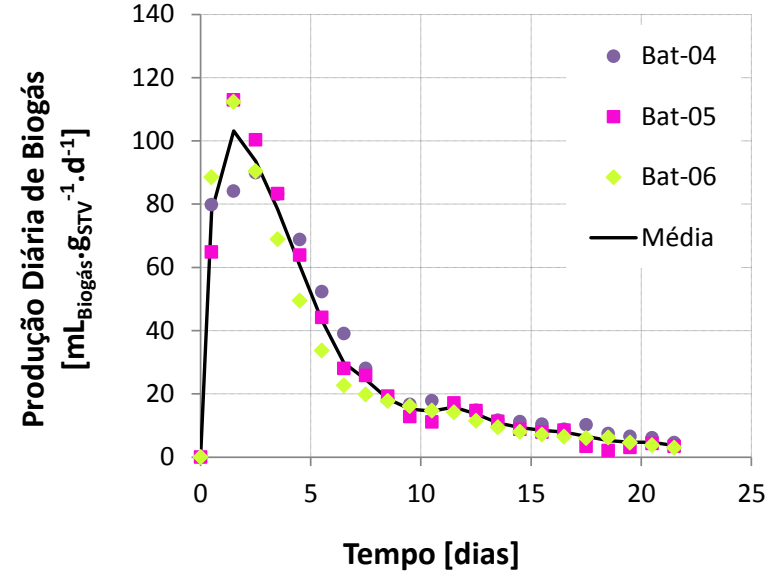

(b) Na Fase 1 a 12 ciclos por dia e $32^{\circ} \mathrm{C}$

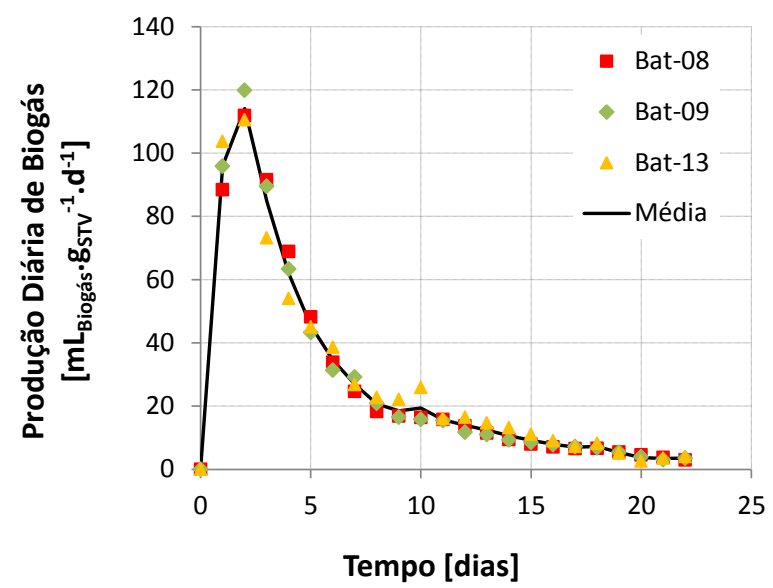

(d) Na Fase 2 a 24 ciclos por dia e $32^{\circ} \mathrm{C}$ com as bateladas selecionadas

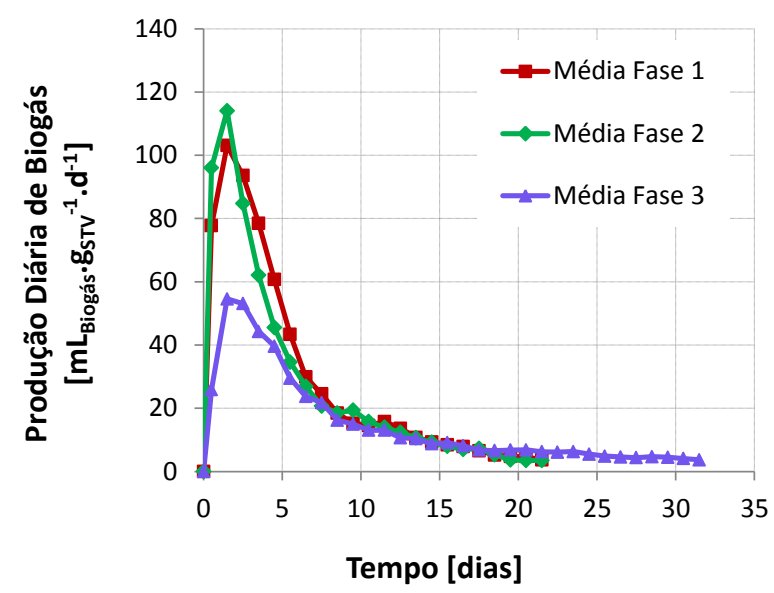

(f) Comparação entre as médias das Fases 1, 2 e 3

Nota-se pela Figura 34 que os picos de produção diária de biogás ocorreram no segundo dia de batelada em todas as fases, independente da taxa de recirculação, 
sendo da ordem de $8 \mathrm{~L} \cdot \mathrm{d}^{-1}$ tanto na Fase 01 quanto na 02 . Convertendo a produção de biogás, medida diariamente, em taxa diária por grama de STV, obtém-se a Figura 35 , que apresenta aspecto semelhante à anterior, entretanto corrige algumas diferenças relacionadas, por exemplo, à massa inicial existente entre as amostras de resíduos. Observa-se por esta figura que a máxima taxa de produção de biogás foi de 113,0 mLBiogás.gSTV ${ }^{-1}$.dia ${ }^{-1}$ na batelada 05 (Fase 01) e 119,8 mLBiogás.gSTV1.dia-1 na batelada 09 (Fase 02). Por outro lado, as produções totais médias de biogás nas Fases 01 e 02 foram, respectivamente, de $46.096 \pm 2.521 \mathrm{~mL}$ e $44.121 \pm$ $722 \mathrm{~mL}$ de biogás. Dessa forma, pode-se concluir que a produção de biogás não foi influenciada significantemente pelo aumento da taxa de recirculação de líquidos, o que responde à terceira questão. A Figura 36 mostra a variação do percentual de metano na composição do biogás ao longo do tempo, de cada batelada, nas quatro fases do experimento. Observa-se, por esta figura que, desde o início das bateladas, o biogás apresentava em sua composição aproximadamente 50\% de metano, e esta porcentagem cresceu ao longo do tempo, atingindo cerca de $70 \%$ a $85 \%$ ao final das bateladas. É provável que essa menor quantidade de metano no início das bateladas seja devido a uma maior geração de $\mathrm{CO}_{2}$, que é produzido também nos processos de solubilização e hidrólise da matéria orgânica, que ocorrem em taxas mais elevadas no início de cada batelada e com o passar do tempo vão se reduzindo, fazendo com que a proporção de metano aumente no biogás (IGLESIAS et al., 2000).

A menor produção de metano na Fase 03 (Figura 36) poderia ser justificada por uma limitação da taxa de hidrólise da matéria orgânica no reator hidrolítico, devido à menor temperatura em relação às demais fases, o que será comprovado nos itens subsequentes, por meio da baixa concentração de matéria orgânica solubilizada no líquido de recirculação, mesmo com uma massa remanescente de sólidos, relativamente alta no reator hidrolítico ao final das bateladas.

Wan et al. (2013), utilizando um digestor anaeróbio de estágio único, tratando uma mistura de resíduos de alimentos, papel e plástico numa proporção de 2:1:1, relataram ter obtido proporções de metano variando de 44,3 a $75,4 \%$, que estão próximos aos valores obtidos na presente pesquisa (faixa de 48,5 a $85,3 \%$ e média geral de $63,0 \%)$. 
Figura 36 - Proporção percentual volumétrica de metano do biogás nas diferentes fases do experimento.

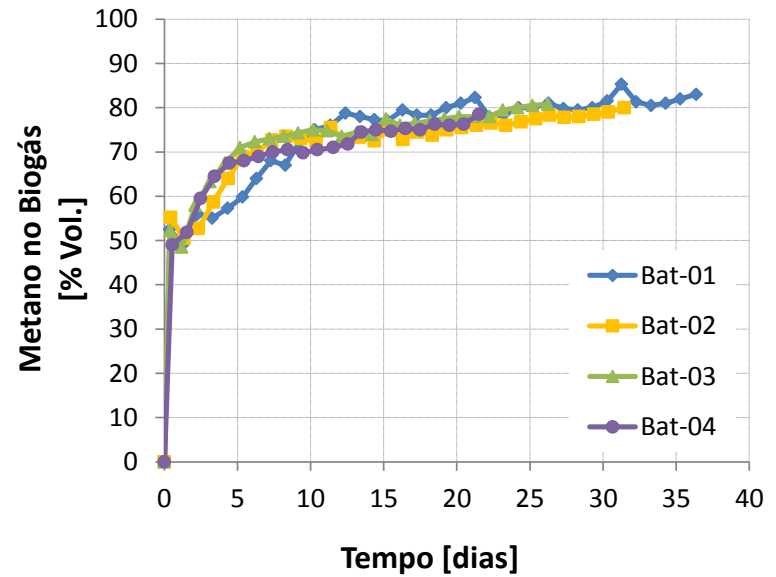

(a) Na fase de adaptação

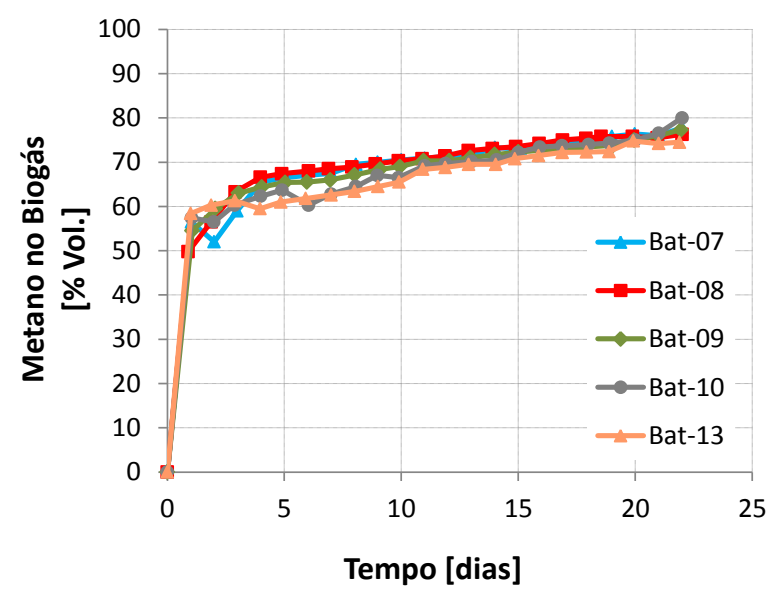

(c) Na Fase 2 a 24 ciclos por dia e $32^{\circ} \mathrm{C}$ com todas as bateladas

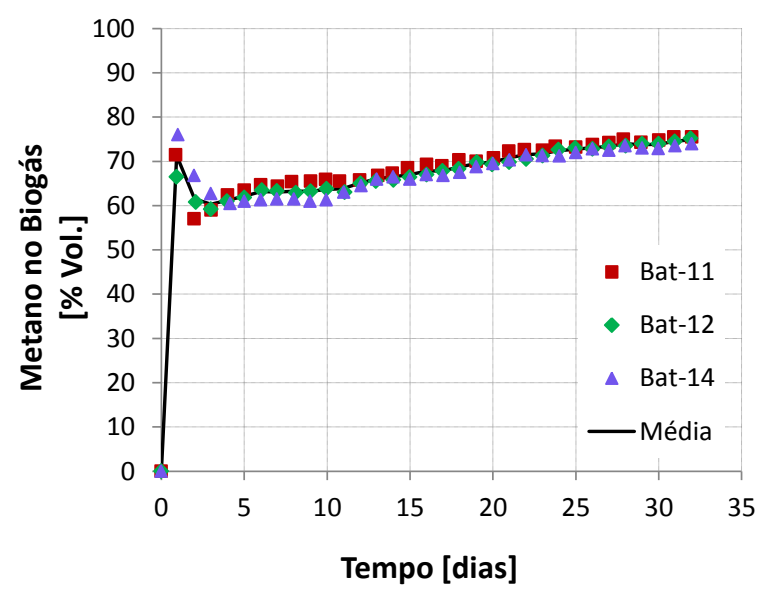

(e) Na Fase 3 a 24 ciclos por dia e $25^{\circ} \mathrm{C}$

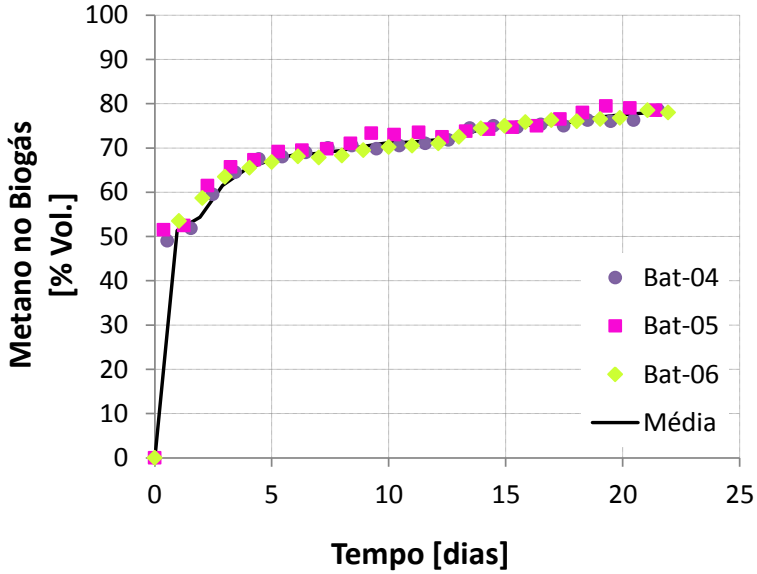

(b) Na Fase 1 a 12 ciclos por dia e $32^{\circ} \mathrm{C}$

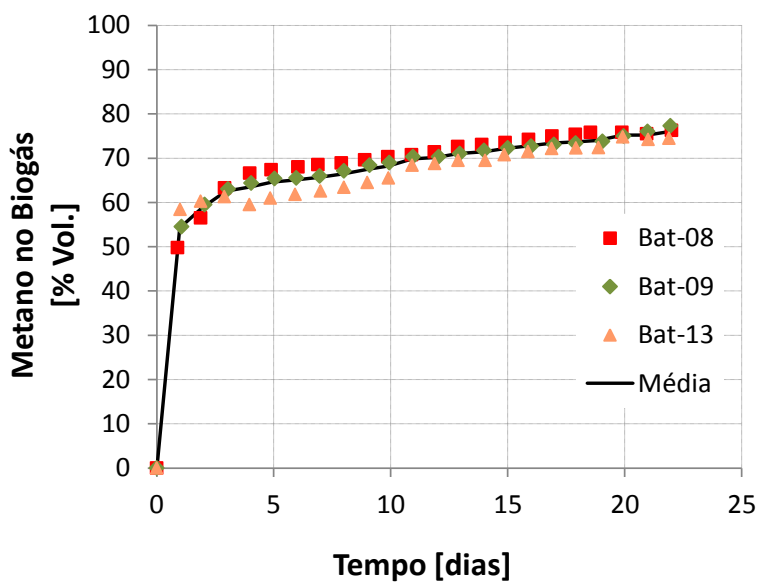

(d) Na Fase 2 a 24 ciclos por dia e $32^{\circ} \mathrm{C}$ com as bateladas selecionadas

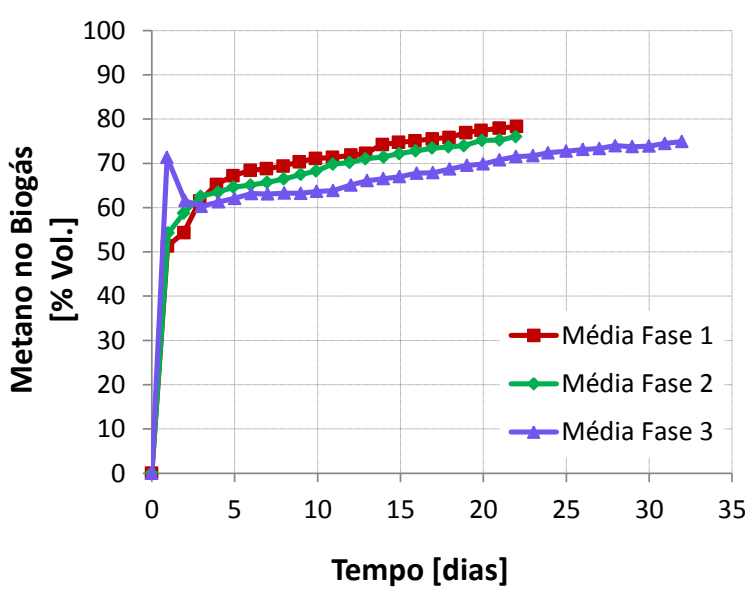

(f) Comparação entre as médias das Fases 1, 2 e 3 
Visando a aferição da metodologia utilizada para determinação da composição de metano no biogás, foi realizada a cromatografia gasosa de uma amostra do biogás coletada na batelada 14, cujos resultados são apresentados na Tabela 22. Desta forma, nota-se que o resultado obtido por neutralização foi próximo ao encontrado pela cromatografia.

Tabela 22 - Comparação entre metodologias para determinação da composição do biogás.

\begin{tabular}{ccccccccc}
\hline \multirow{2}{*}{ Fração } & \multicolumn{3}{c}{ Cromatografia [\% vol.] } & & \multicolumn{3}{c}{ Por Neutralização em NaOH [\% vol.] } \\
\cline { 2 - 3 } & Injeção 1 & Injeção 2 & Média & & Injeção 1 & Injeção 2 & Média \\
\hline $\mathbf{C O}_{2}$ & 30,1 & 30,4 & 30,2 & & 34,0 & 32,0 & 33,0 \\
$\mathbf{C H}_{4}$ & 68,0 & 65,7 & 66,9 & & 66,0 & 68,0 & 67,0 \\
$\mathbf{N}_{\mathbf{2}}$ & 1,9 & 3,9 & 2,9 & & - & - & - \\
\hline
\end{tabular}

A partir da caracterização das amostras de resíduos iniciais, determinou-se a concentração de STV igual a 70,87 g, que foi considerada constante em todas as bateladas do experimento, uma vez que as amostras de resíduos apresentam composições semelhantes. A Tabela 23 e a Tabela 24 mostram, respectivamente, os volumes específicos de biogás e de metano nas 14 bateladas realizadas, agrupadas conforme as 4 fases de operação do sistema.

Pavan et al. (1999a $\mathrm{a}^{9}$ ) apud Mata-Alvarez et al. (2000), utilizando um sistema termofílico de duas fases com alto teor de sólidos, tratando resíduos de frutas e vegetais, obtiveram produção de biogás de $600 \mathrm{~mL}_{\text {Biogás. }} \mathrm{gsTV}^{-1}$, valor este muito próximo ao médio obtido neste trabalho igual a $594 \mathrm{~mL}_{\text {Biogás. }} \mathrm{gsTV}{ }^{-1}$.

\footnotetext{
${ }^{9}$ Pavan, P., Battistoni, P., Traverso, P.G., Cecchi, F., Mata-Alvarez, J.,1999a. Two-phase anaerobic digestion of source sorted of MSW: performance and kinetic study. In: Mata-Alvarez, J., Tilche, A., Cecchi, F. (Eds.), Proceedings of the Second International Symposium on Anaerobic Digestion of Solid Wastes, Barcelona, vol. 1. Gràfiques 92, $15 \pm 18$ June, pp. $91 \pm 98$.
} 
Tabela 23 - Volumes totais de biogás produzidos nas bateladas 01 a 14.

\begin{tabular}{|c|c|c|c|c|}
\hline Batelada & $\begin{array}{l}\text { Volume Total } \\
\text { [mL } \\
\text { Biogás }]\end{array}$ & $\begin{array}{l}\text { STV }_{\text {Removido }} \\
\text { [g] }\end{array}$ & $\begin{array}{c}\text { Volume } \\
\text { Específico } \\
{\left[\mathrm{mL}_{\text {Biogás. }} \cdot \mathrm{g}_{\mathrm{sTV}}{ }^{-1}\right]}\end{array}$ & $\begin{array}{l}\text { Volume Específico } \\
\left.\text { [mL }_{\text {Biogás. }} \text { gstv Remov }^{-1}\right]\end{array}$ \\
\hline 01 & 46480 & 62,49 & 655,84 & 743,79 \\
\hline 02 & 43192 & 55,74 & 609,44 & 774,92 \\
\hline 03 & 45885 & 64,47 & 647,43 & 711,68 \\
\hline 04 & 48591 & 58,28 & 685,61 & 833,79 \\
\hline Méd. Adapt. & 46037 & 60,25 & 649,58 & 766,04 \\
\hline 04 & 48591 & 58,28 & 685,61 & 833,79 \\
\hline 05 & 46146 & 55,82 & 651,13 & 826,76 \\
\hline 06 & 43550 & 56,92 & 614,48 & 765,07 \\
\hline Méd. Fase 01 & 46096 & 57,01 & 650,41 & 808,54 \\
\hline 07 & 41618 & 57,18 & 587,23 & 727,87 \\
\hline $08^{*}$ & 43550 & 56,08 & 614,48 & 776,52 \\
\hline $09^{*}$ & 43881 & 56,09 & 619,16 & 782,34 \\
\hline 10 & 39777 & 52,58 & 561,26 & 756,47 \\
\hline $13^{*}$ & 44932 & 56,00 & 633,99 & 802,40 \\
\hline Média Geral Fase 02 & 42752 & 55,59 & 603,23 & 769,12 \\
\hline Méd. Fase 02* & 44121 & 55,28 & 622,55 & 787,09 \\
\hline 11 & 35903 & 56,07 & 506,60 & 640,30 \\
\hline 12 & 33394 & 55,40 & 471,20 & 602,75 \\
\hline 14 & 32481 & 55,90 & 458,31 & 581,08 \\
\hline Méd. Fase 03 & 33926 & 55,79 & 478,70 & 608,04 \\
\hline Média Geral & 42099 & 57,07 & 594,01 & 737,55 \\
\hline
\end{tabular}

OBS: Fases Adaptação e 01: $32^{\circ} \mathrm{C}$ e $12 \mathrm{X}$; Fase 02: $32^{\circ} \mathrm{C}$ e $24 \mathrm{X}$; Fase $03: 25^{\circ} \mathrm{C}$ e $24 \mathrm{X}$; Volumes obtidos à temperatura ambiente $\left(\sim 25^{\circ} \mathrm{C}\right)$; ${ }^{*}$ Bateladas selecionadas para média da Fase 02.

Comparando-se os resultados ilustrados na Tabela 24 com os mostrados na Tabela 15, que traz os resultados de diversos trabalhos tratando resíduos com características semelhantes à desta pesquisa, pode-se notar que o desempenho do sistema utilizado no presente trabalho nas Fases 01 e 02 se compara ao dos que apresentaram os melhores desempenhos. Os resultados obtidos neste trabalho com um sistema mesofílico (Fase $01=423 \mathrm{~mL}_{\text {Metano. }} . \mathrm{gstV}^{-1}$; Fase $02=368 \mathrm{~mL}_{\text {Metano. }} . \mathrm{gstV}^{-1}$ ) são da mesma ordem de grandeza dos apresentados por Zhang et al (2007) que utilizou um sistema termofílico em batelada $\left(440 \mathrm{~mL}_{\text {Metano. }} \cdot \mathrm{gsTV}^{-1}\right)$, o que mostra 0 potencial do presente sistema. 
Tabela 24 - Volumes totais de metano produzidos nas bateladas 01 a 14.

\begin{tabular}{|c|c|c|c|c|c|}
\hline Batelada & $\begin{array}{c}\text { Metano } \\
{[\%]}\end{array}$ & $\begin{array}{l}\text { Volume } \\
\text { Total } \\
{\left[\mathrm{mL}_{\mathrm{CH} 4}\right]}\end{array}$ & $\begin{array}{c}\text { Volume } \\
\text { Específico } \\
{\left[\mathrm{mL}_{\left.\mathrm{CH} 4 \cdot \mathrm{gsT}^{-1}\right]}\right.}\end{array}$ & $\begin{array}{c}\text { Volume } \\
\text { Específico } \\
{\left[\mathrm{mL}_{\left.\mathrm{CH} 4 \cdot \mathrm{gsTV}^{-1}\right]}\right.}\end{array}$ & $\begin{array}{l}\text { Volume Específico } \\
{\left[\mathrm{mL}_{\mathrm{CH} 4 \cdot \mathrm{g}_{\mathrm{stV}} \text { Remov }}{ }^{-1}\right]}\end{array}$ \\
\hline 01 & 66,52 & 30921 & 404,56 & 436,29 & 494,80 \\
\hline 02 & 63,81 & 27561 & 360,60 & 388,88 & 494,47 \\
\hline 03 & 64,86 & 29763 & 389,40 & 419,95 & 461,62 \\
\hline 04 & 62,36 & 30302 & 396,46 & 427,55 & 519,96 \\
\hline Média Adapt. & 64,39 & 29636 & 387,75 & 418,17 & 492,71 \\
\hline 04 & 62,36 & 30302 & 396,46 & 427,55 & 519,96 \\
\hline 05 & 63,01 & 29078 & 380,45 & 410,29 & 520,97 \\
\hline 06 & 70,23 & 30585 & 400,16 & 431,55 & 537,30 \\
\hline Média Fase 01 & 65,20 & 29988 & 392,36 & 423,13 & 526,08 \\
\hline 07 & 63,96 & 26617 & 348,25 & 375,57 & 465,52 \\
\hline $08^{*}$ & 62,23 & 27101 & 354,58 & 382,40 & 483,23 \\
\hline $09^{*}$ & 57,75 & 25340 & 331,55 & 357,55 & 451,79 \\
\hline 10 & 58,92 & 23435 & 306,62 & 330,68 & 445,69 \\
\hline $13^{*}$ & 57,41 & 25796 & 337,50 & 363,98 & 460,66 \\
\hline $\begin{array}{l}\text { Média Geral } \\
\text { Fase } 02\end{array}$ & 60,05 & 25658 & 335,70 & 362,03 & 461,38 \\
\hline Média Fase $02^{*}$ & 59,13 & 26079 & 341,21 & 367,98 & 465,23 \\
\hline 11 & 63,84 & 22922 & 299,91 & 323,43 & 408,79 \\
\hline 12 & 62,47 & 20863 & 272,96 & 294,37 & 376,56 \\
\hline 14 & 64,27 & 20877 & 273,15 & 294,58 & 373,49 \\
\hline Média Fase 03 & 63,53 & 21554 & 282,01 & 304,13 & 386,28 \\
\hline Média Geral & 62,98 & 26511 & 346,87 & 374,08 & 463,92 \\
\hline
\end{tabular}

OBS: Fases Adaptação e 01: $32^{\circ} \mathrm{C}$ e 12X; Fase 02: $32^{\circ} \mathrm{C}$ e $24 \mathrm{X}$; Fase 03: $25^{\circ} \mathrm{C}$ e $24 \mathrm{X}$; Volumes obtidos à temperatura ambiente $\left(\sim 25^{\circ} \mathrm{C}\right) .{ }^{*}$ Bateladas selecionadas para média da Fase 02.

Nesta pesquisa, ao se observar os resultados da Fase 03, nota-se que a produção média de biogás foi inferior às das Fases 01 e 02, nas quais foi utilizada uma maior temperatura. Se por um lado o aquecimento dos sistemas de tratamento eleva os gastos energéticos e, portanto, os custos operacionais, por outro lado, o não aquecimento pode levar a unidades com dimensões maiores e, dessa forma, com custos de implantação mais elevados. Destarte, a escolha da melhor solução envolve um estudo técnico e econômico para cada caso. 
Buscando encontrar a situação mais favorável dentre as pesquisadas e mesmo sabendo-se que a escala do reator pode levar a conclusões diferentes, será feita a seguir uma análise simplificada desta questão, da Tabela 25 à Tabela 27, considerando duas situações apresentadas nesta pesquisa, que são as operações a $25 \stackrel{\circ}{\circ}$ e e $32 \stackrel{\circ}{\circ}$ com mesma taxa de recirculação e tempo de reação comum, de 22 dias.

Tabela 25 - Dados utilizados para análise comparativa entre as Fases 02 e 03.

\begin{tabular}{|c|c|c|c|}
\hline Parâmetro & Unidade & Fase 2 & Fase 3 \\
\hline Temperaturas & $\stackrel{\circ}{\circ}$ & $32 \pm 2$ & $25 \pm 2$ \\
\hline Taxa de Recirculação de Líquidos & ciclos/dia & 24 & 24 \\
\hline Tempo de Reação & dias & 22 & 22 \\
\hline Volume do Reator Hidrolítico & $\mathrm{L}$ & 1,00 & 1,00 \\
\hline Volume do Filtro Anaeróbio & $\mathrm{L}$ & 10,73 & 10,73 \\
\hline Produção de Biogás ${ }^{1}$ & $\mathrm{~L}_{\text {Biogás} / \text { Bat. }}$ & 44,12 & 30,47 \\
\hline Percentual Médio de Metano & $\%$ & 59,13 & 62,46 \\
\hline Produção de Metano ${ }^{1}$ & $\mathrm{~L}_{\mathrm{CH}} /$ Bat. & 26,08 & 19,03 \\
\hline Número de Mols & Mols de $\mathrm{CH}_{4} / \mathrm{Bat}$. & 0,977 & 0,713 \\
\hline Produção de Metano Padronizada & $\mathrm{L}_{\mathrm{CH} 4} /$ Bat. & 21,90 & 15,98 \\
\hline Potencial Energético & $\mathrm{kJ} /$ Bat. & 785,2 & 572,9 \\
\hline
\end{tabular}

${ }^{1}$ Medido a $25 \stackrel{\circ}{\circ} \mathrm{C}$ em Mariotte fora da câmara de aquecimento (altitude de $726 \mathrm{~m}$ e pressão de 0,917 atm).

${ }^{2}$ Convertida para as condições padrão de pressão (1 atm) e temperatura $\left(0^{\circ} \mathrm{C}\right)$.

Os resultados mostrados na Tabela 27 foram obtidos a partir da metodologia apresentada por Metcalf e Eddy (2016) para aquecimento de digestores anaeróbios. Observando-se esses resultados, nota-se um excedente energético $23,6 \%$ maior se o sistema for aquecido em comparação à operação em temperatura ambiente, considerando-se uma cidade de médio porte de 100 mil habitantes. Entretanto, para pequenos municípios, para o saneamento rural ou descentralizado, pode ser que um tratamento sem aquecimento seja mais adequado ou até mesmo, o excedente energético não seja significativo. 
Tabela 26 - Cálculos e considerações para análise comparativa.

\begin{tabular}{|c|c|c|c|}
\hline Consideração (Parâmetro) & Unidade & Valor & Fonte: \\
\hline População Hipotética & habitantes & 100.000 & O Autor (Adotado) \\
\hline Geração Per-capita de M.O. & $\mathrm{kg} / \mathrm{dia}$ & 0,50 & O Autor (Adotado) \\
\hline Geração Total de M.O. em 22 dias & $\mathrm{t}$ & 1.100 & Calculado \\
\hline Massa Específica & $t / m^{3}$ & 1,00 & O Autor (Adotado) \\
\hline Volume Total de M.O. em 22 dias & $\mathrm{m}^{3}$ & 1.100 & Calculado \\
\hline Vol. Reator Hidrolítico Proporcional & $\mathrm{m}^{3}$ & 2.529 & Calculado \\
\hline Vol. Filtro Anaeróbio Proporcional & $\mathrm{m}^{3}$ & 27.133 & Calculado \\
\hline Altura dos Reatores & $\mathrm{m}$ & 10 & O Autor (Adotado) \\
\hline Área do Reator Hidrolítico & $\mathrm{m}^{2}$ & 253 & Calculado \\
\hline Área do Filtro Anaeróbio & $\mathrm{m}^{2}$ & 2713 & Calculado \\
\hline Número de Reatores Hidrolíticos & un. & 4 & O Autor (Adotado) \\
\hline Número de Filtros Anaeróbios & un. & 4 & O Autor (Adotado) \\
\hline Diâmetro do Reator Hidrolítico & $\mathrm{m}$ & 9 & O Autor (Adotado) \\
\hline Diâmetro de cada Filtro Anaeróbio & $\mathrm{m}$ & 30 & O Autor (Adotado) \\
\hline $\begin{array}{l}\text { Área da Base de cada Reator } \\
\text { Hidrolítico }\end{array}$ & $\mathrm{m}^{2}$ & 63,6 & Calculado \\
\hline Área da Base de cada Filtro Anaeróbio & $\mathrm{m}^{2}$ & 706,9 & Calculado \\
\hline Área Lateral de cada Reator Hidrolítico & $\mathrm{m}^{2}$ & 282,7 & Calculado \\
\hline Área Lateral de cada Filtro Anaeróbio & $\mathrm{m}^{2}$ & 942,5 & Calculado \\
\hline $\begin{array}{l}\text { Espessura das Paredes dos Reatores } \\
\text { em Concreto Armado }\end{array}$ & $\mathrm{mm}$ & 300 & O Autor (Adotado) \\
\hline $\begin{array}{l}\text { Coeficiente de Transferência de Calor } \\
\text { das Paredes com Isolamento }\end{array}$ & $\mathrm{W} / \mathrm{m}^{2} \cdot{ }^{\circ} \mathrm{C}$ & 0,7 & Metcalf e Eddy (2016) \\
\hline $\begin{array}{l}\text { Coeficiente de Transferência de Calor } \\
\text { das Bases em Contato com Solo Seco }\end{array}$ & $\mathrm{W} / \mathrm{m}^{2} \cdot{ }^{\circ} \mathrm{C}$ & 1,7 & Metcalf e Eddy (2016) \\
\hline $\begin{array}{l}\text { Coeficiente de Transferência de Calor } \\
\text { das Coberturas com Isolamento }\end{array}$ & $\mathrm{W} / \mathrm{m}^{2} \cdot{ }^{\circ} \mathrm{C}$ & 1,45 & Metcalf e Eddy (2016) \\
\hline Temperatura Média do Ar & ${ }^{\circ} \mathrm{C}$ & 25,0 & O Autor (Adotado) \\
\hline Temperatura Média do Solo & ${ }^{\circ} \mathrm{C}$ & 20,0 & O Autor (Adotado) \\
\hline Temperatura Inicial dos Resíduos & ${ }^{\circ} \mathrm{C}$ & 25,0 & O Autor (Adotado) \\
\hline Calor Específico do Resíduo / lixiviado & $\mathrm{J} / \mathrm{kg} \cdot{ }^{\circ} \mathrm{C}$ & 4.200 & Metcalf e Eddy (2016) \\
\hline
\end{tabular}

Desta forma, a vantagem de se operar um reator a temperatura ambiente ou aquecê-lo, está intimamente ligado ao porte do tratamento, à área disponível, bem como a principal finalidade do mesmo, quer seja priorizando a utilização energética do biogás ou a minimização da área necessária para o tratamento de resíduos. 
Tabela 27 - Resultados obtidos na análise comparativa entre as Fases 02 e 03.

\begin{tabular}{lccc}
\hline \multicolumn{1}{c}{ Parâmetro } & Unidade & Fase 2 & Fase 3 \\
\hline Calor Necessário para Aquecer o Resíduo & $\mathrm{kJ} /$ Bat. & $3,23 \times 10^{7}$ & $0^{*}$ \\
Perdas de Calor por Condução nas Paredes & $\mathrm{kJ} /$ Bat. & $4,56 \times 10^{7}$ & $0^{*}$ \\
Perdas de Calor por Condução nos Pisos & $\mathrm{kJ} /$ Bat. & $1,20 \times 10^{8}$ & $4,98 \times 10^{7}$ \\
Perdas de Calor por Condução nas Coberturas & $\mathrm{kJ} /$ Bat. & $5,95 \times 10^{7}$ & $0^{*}$ \\
Perdas de Calor Total & $\mathrm{kJ} /$ Bat. & $2,25 \times 10^{8}$ & $4,98 \times 10^{7}$ \\
Calor Necessário Total & $\mathrm{kJ} /$ Bat. & $2,57 \times 10^{8}$ & $4,98 \times 10^{7}$ \\
Energia Total Gerada pelo Biogás & $\mathrm{kJ} /$ Bat. & $1,99 \times 10^{9}$ & $1,45 \times 10^{9}$ \\
\hline Excedente Energético & $\mathrm{kJ} /$ Bat. & $1,73 \times 10^{9}$ & $1,40 \times 10^{9}$ \\
\hline
\end{tabular}

* Não há diferença de temperatura.

\subsection{Viabilidade do Uso do Lixiviado de Aterro Sanitário como Líquido de Recirculação}

A análise do liquido de recirculação objetivou responder a quatro importantes questões relacionadas à configuração do sistema pesquisado: 1) $O$ volume de lixiviado e sua alcalinidade foram suficientes para garantir o tamponamento e a estabilidade operacional do sistema? 2) O lixiviado serviu ao propósito de veículo de transporte da matéria orgânica solubilizada entre o reator hidrolítico e $\circ$ filtro anaeróbio? 3) Reutilizando-se os lixiviados entre as bateladas subsequentes, ocorreu acúmulo de matéria orgânica recalcitrante? e 4) Ocorreu acúmulo de material inorgânico, tais como sais ou nitrogênio amoniacal?

Buscando-se responder à primeira questão, foram avaliadas as alterações das variáveis $\mathrm{pH}$, alcalinidade total e ácidos voláteis totais ao longo do tempo, sendo esta variação ilustrada na Figura 37, Figura 38 e Figura 39, respectivamente.

Observando-se os resultados de $\mathrm{pH}$ ao longo das bateladas, nota-se que nas três primeiras, os valores iniciais de $\mathrm{pH}$ foram maiores, situando-se entre 8,2 e 8,4, devido à não reutilização dos lixiviados entre uma batelada e outra. A partir da batelada 04 foram reutilizados os lixiviados das bateladas anteriores, repondo-se 0 que era retirado para as análises, o que levou a uma queda dos valores iniciais para uma faixa de $\mathrm{pH}$ de 7,7 a 7,8. Nota-se que, de forma geral, os valores de $\mathrm{pH}$ mínimos foram registrados entre o primeiro e o segundo dia de cada batelada, e estes valores, independente da fase de operação, sempre ficaram em torno de 7,2, 
estando este valor dentro do intervalo considerado ótimo para as arqueias metanogênicas, que se situa entre 6,5 e 8,0 (LETTINGA ASSOCIATES FOUNDATION, 2009).

Figura 37 - Variações do pH nas diferentes fases do experimento.

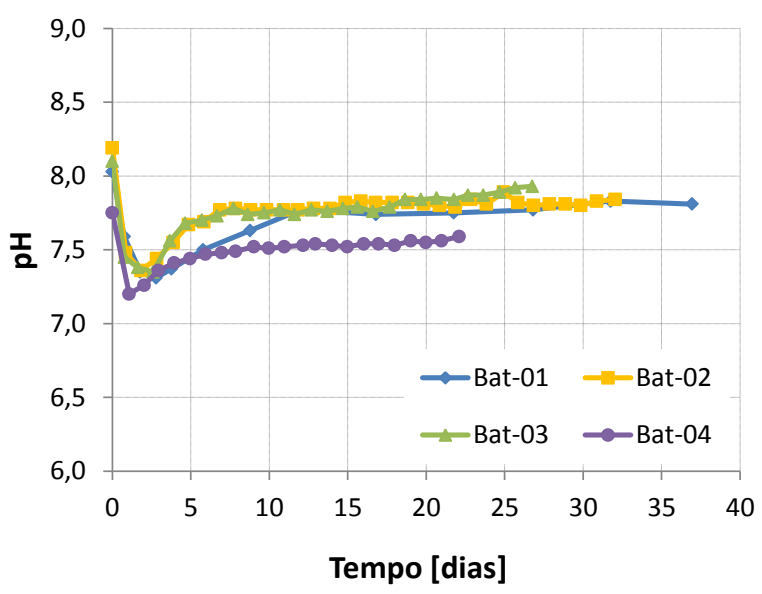

(a) Na Fase de Adaptação

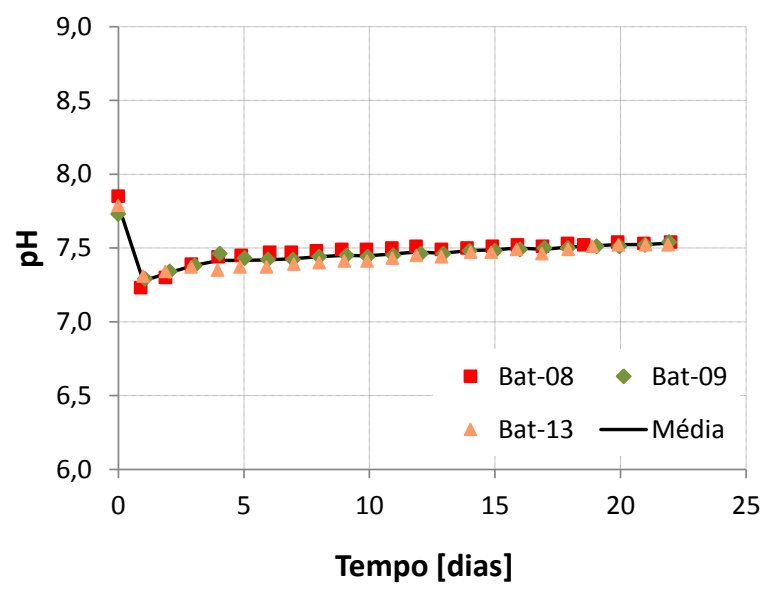

(c) Na Fase 2 a 24 ciclos por dia e $32^{\circ} \mathrm{C}$

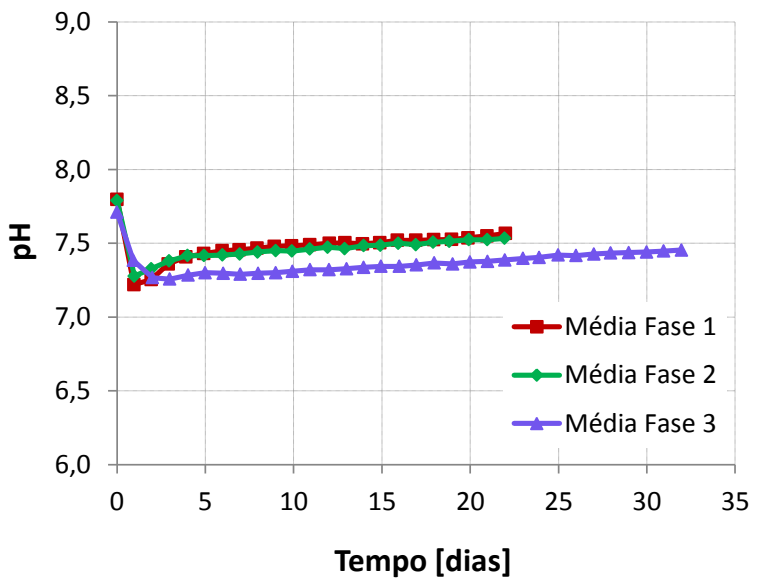

(e) Comparação entre as médias das Fases 1, 2 e 3

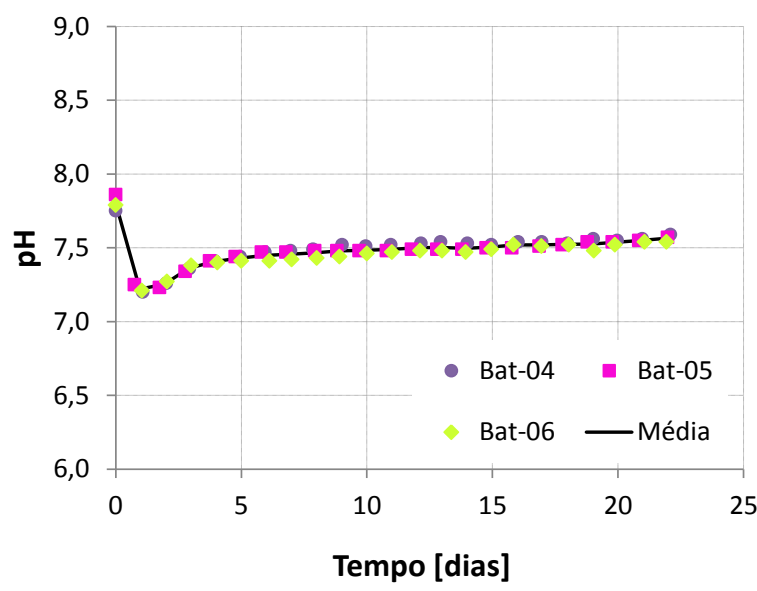

(b) Na Fase 1 a 12 ciclos por dia e $32^{\circ} \mathrm{C}$

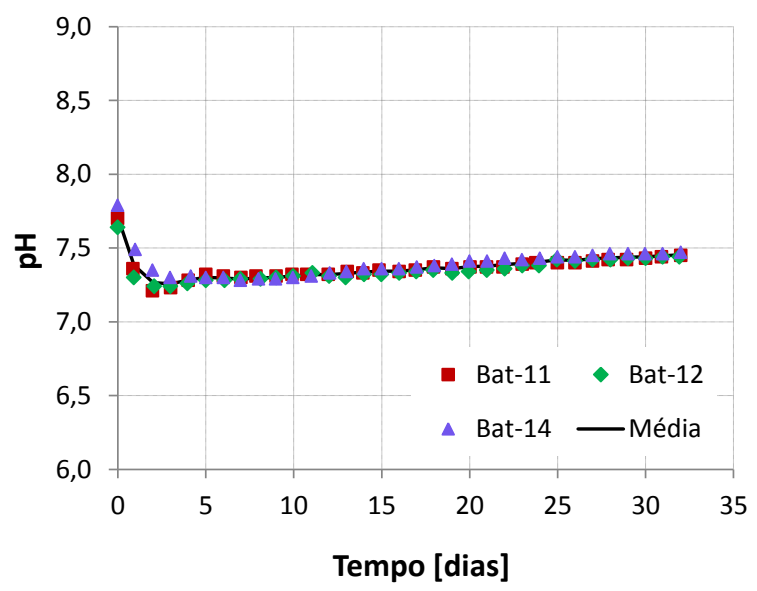

(d) Na Fase 3 a 24 ciclos por dia e $25^{\circ} \mathrm{C}$

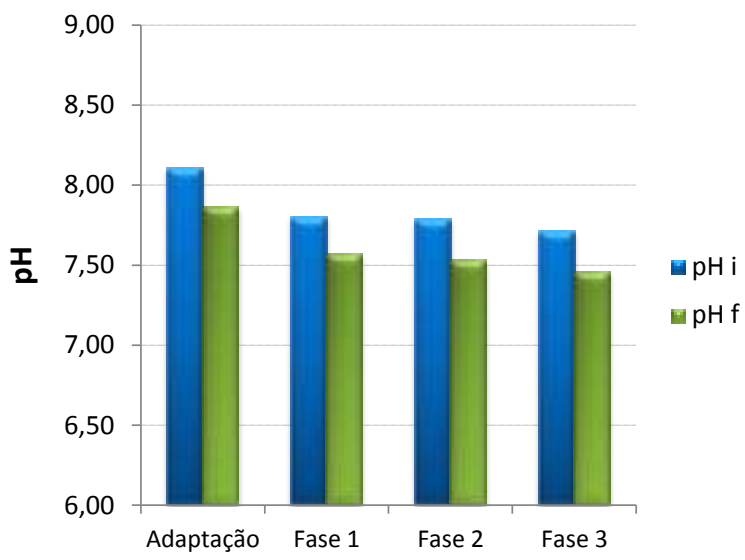

(f) $\mathrm{pH}$ inicial e final nas quatro fases 
Observa-se, também, que ao final das bateladas, $0 \mathrm{pH}$ subia novamente, estabilizando-se em torno de 7,5, e portanto abaixo do $\mathrm{pH}$ inicial $(7,7$ a 7,8$)$. Isto ocorria devido ao equilíbrio entre o líquido e os gases da atmosfera interna do reator, rica em $\mathrm{CO}_{2}$, que se solubilizava, formando ácido carbônico, tamponando o sistema em $\mathrm{pH}$ sempre mais baixo, e ao se expor o lixiviado à atmosfera para reinício da próxima batelada, este $\mathrm{CO}_{2}$ era liberado, elevando-se novamente $\mathrm{o} \mathrm{pH}$, devido à presença de $\mathrm{N}$-amoniacal no líquido.

Com relação aos resultados de alcalinidade total, nota-se que na fase de adaptação, as quedas foram mais acentuadas que nas demais fases, sendo que na última, a alcalinidade praticamente manteve-se estável. Este comportamento está intrinsicamente relacionado às taxas de acidificação da matéria orgânica e de consumo de ácidos pelo sistema. Nesta etapa de acidificação/acetogênese, pode ocorrer acúmulo de ácidos no sistema, levando ao consumo da alcalinidade e, consequentemente, queda do $\mathrm{pH}$ para valores abaixo da faixa ótima operacional, 0 que não ocorreu em nenhuma das bateladas deste experimento, devido ao excesso de alcalinidade no sistema, decorrente do volume de lixiviado utilizado $(\sim 6,74 \mathrm{~L})$ e de sua elevada capacidade tampão.

Uma forma de se avaliar a capacidade de não acidificação em um digestor anaeróbio poderia ser por meio da determinação da massa equivalente total de alcalinizantes em termos de carbonato de cálcio em relação à massa de sólidos totais voláteis no sistema. Nesta pesquisa, a concentração média inicial de substrato foi de 70,9 gstv, assim, considerando-se os volumes iniciais de lixiviados de aproximadamente $6,74 \mathrm{~L}$ e as respectivas alcalinidades totais médias para todas as fases de operação deste sistema, foram calculadas as relações $M_{A T} / M_{S T V}$ (Tabela 28). Quanto maior for esta relação, melhor será a condição inicial de operação do sistema. Ao se calcular o valor da relação $\mathrm{M}_{\mathrm{AT}} / \mathrm{M}_{\mathrm{STV}}$ para o trabalho de Dillenburg (2006) ao tratar a FORSU, chegou-se ao valor de 0,064, sendo que o autor relatou que no início das bateladas, o pH nos reatores de sólidos eram de 5,4 e levou-se cerca de 30 dias de operação para as condições se estabilizaram e se iniciar a metanogênese. Vilela (2015), ao operar três reatores contendo diferentes proporções de FORSU, lodo de esgoto e serragem, obteve no início das bateladas relações $M_{A T} / M_{S T V}$ variando entre 0,037 e 0,080 para os sistemas. Segundo a 
autora, apesar da adição de alcalinizantes durante o processo, em todos os reatores foi observada o ocorrência de acidificações, com pH chegando a 3,37. Todavia, ao final das bateladas, o sistema que apresentou a melhor remoção de STV foi o que apresentou a maior relação $\mathrm{M}_{\mathrm{AT}} / \mathrm{M}_{\mathrm{STV}}$ inicial. Nota-se que tanto Dillenburg (2006) quanto Vilela (2015) que relataram acidificações em seus sistemas trabalharam com relações $M_{A T} / M_{S T V}$ iniciais bem menores que as utilizadas neste trabalho, evidenciando que esta relação pode ser um indicador da possível ocorrência de acidificação, embora não se tenham informações suficientes ainda para se estabelecer a partir de que valores a acidificação poderá ocorrer ou não.

De acordo com Contrera (2008), a alcalinidade total de um lixiviado de aterro sanitário está intimamente ligada à concentração de nitrogênio amoniacal. Segundo o autor estes dois parâmetros podem ser correlacionados segundo as equações 01 e 02, respectivamente, para lixiviados coletados no Brasil e com dados obtidos na literatura internacional.

$$
\begin{aligned}
& \text { NAT }=0,2440 \cdot A T-354,8 \quad\left[r^{2}=0,9904\right] \\
& \text { NAT }=0,2285 \cdot A T-174,6 \quad\left[r^{2}=0,9368\right]
\end{aligned}
$$

Sendo NAT a concentração de nitrogênio amoniacal total [mgN/L] e AT é a alcalinidade total $\left[\mathrm{mgCaCO}_{3} / \mathrm{L}\right]$ do lixiviado.

O lixiviado utilizado nesta pesquisa possuía alcalinidade total (caracterização) igual a $11.997 \mathrm{mgCaCO}_{3} / \mathrm{L}$ que, de acordo com a equação 01, resultaria em uma concentração de $\mathrm{N}$-amoniacal igual a $2.572 \mathrm{mgN} / \mathrm{L}$, que é bem próxima à concentração encontrada na caracterização de 2.642 mgN/L (diferença de 2,6 \%).

Tabela 28 - Determinação da relação entre a alcalinidade total disponível e a concentração inicial de substrato no sistema para as 4 fases de operação (MAT/MSTV).

\begin{tabular}{cccccc}
\hline Fase & $\begin{array}{c}\text { Vol. } \\
{[\mathbf{L}]}\end{array}$ & $\begin{array}{c}\mathbf{M}_{\mathbf{S T V}}{ }^{*} \\
{[\mathbf{g S T V}]}\end{array}$ & $\begin{array}{c}\mathbf{A T}^{*} \\
{\left[\mathbf{g C a C O}_{3} / \mathbf{L}\right]}\end{array}$ & $\begin{array}{c}\mathbf{M}_{\mathbf{A T}}{ }^{*} \\
{[\mathbf{g}]}\end{array}$ & $\mathbf{M}_{\mathbf{A T}} \mathbf{M}_{\mathbf{S T V}}$ \\
\hline Adaptação $^{\mathbf{1}}$ & 6,74 & 70,9 & 12,56 & 84,65 & 1,193 \\
$\mathbf{0 1}$ & 6,74 & 70,9 & 11,73 & 79,06 & 1,115 \\
$\mathbf{0 2}$ & 6,74 & 70,9 & 11,02 & 74,27 & 1,047 \\
$\mathbf{0 3}$ & 6,74 & 70,9 & 10,89 & 73,40 & 1,035 \\
\hline
\end{tabular}

\footnotetext{
* Valores médios;

${ }_{1}^{1}$ Para este caso foram consideradas as bateladas de 01 a 03.

Fases Adaptação e 01: $32^{\circ} \mathrm{C}$ e $12 \mathrm{X}$; Fase 02: $32^{\circ} \mathrm{C}$ e $24 \mathrm{X}$; Fase 03: $25^{\circ} \mathrm{C}$ e $24 \mathrm{X}$.
} 
Figura 38 - Variações da Alcalinidade Total nas diferentes fases do experimento.

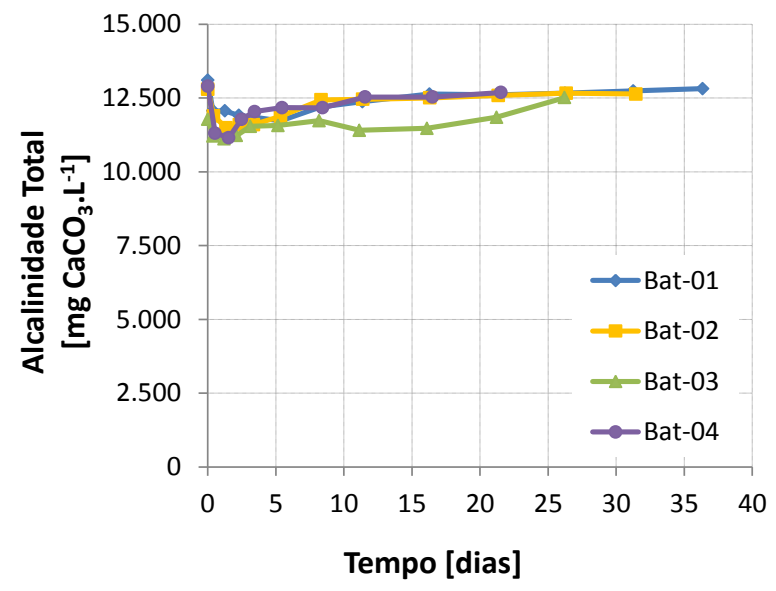

(a) Na Fase de Adaptação

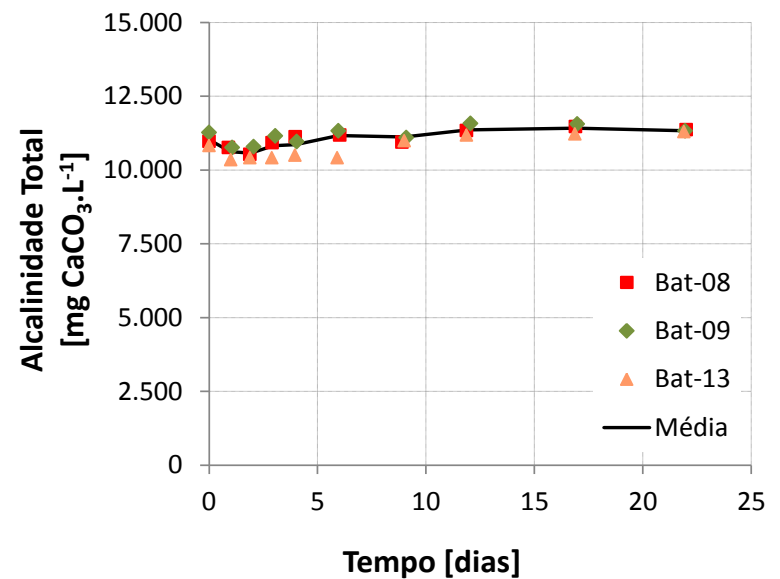

(c) Na Fase 2 a 24 ciclos por dia e $32^{\circ} \mathrm{C}$

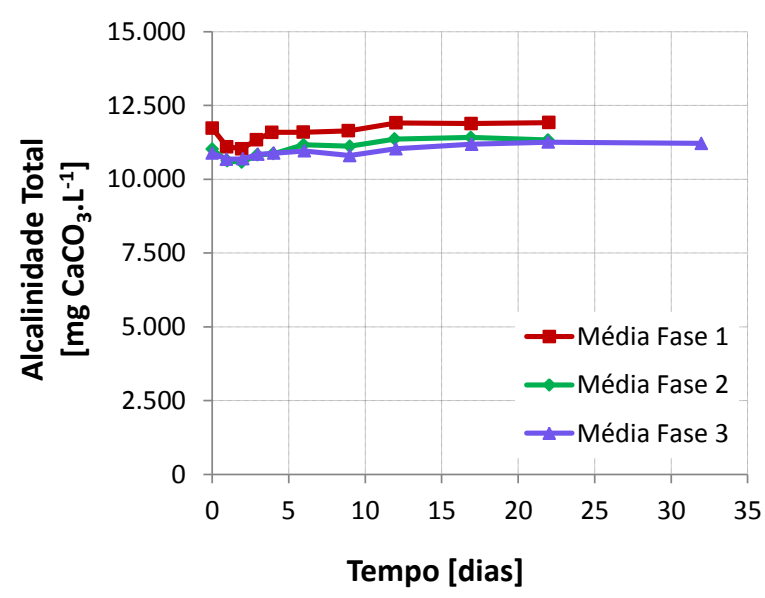

(e) Comparação entre as médias das Fases 1, 2 e 3

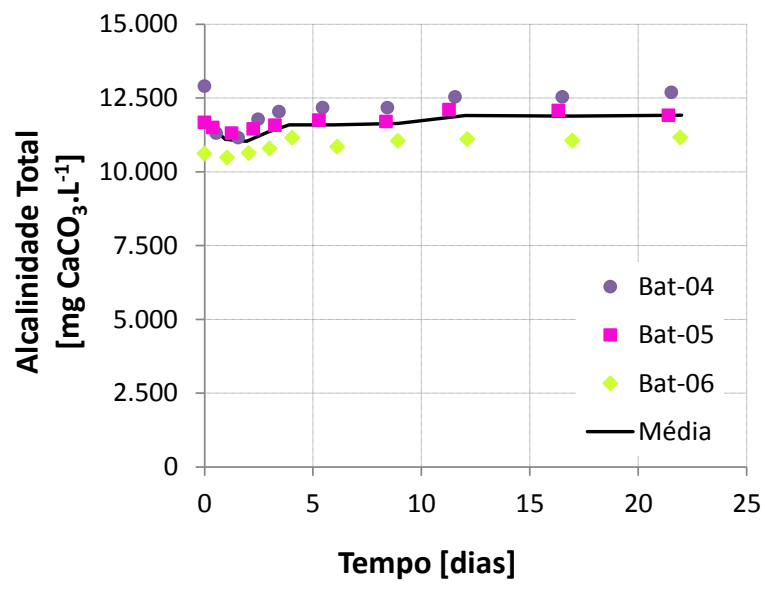

(b) Na Fase 1 a 12 ciclos por dia e $32^{\circ} \mathrm{C}$

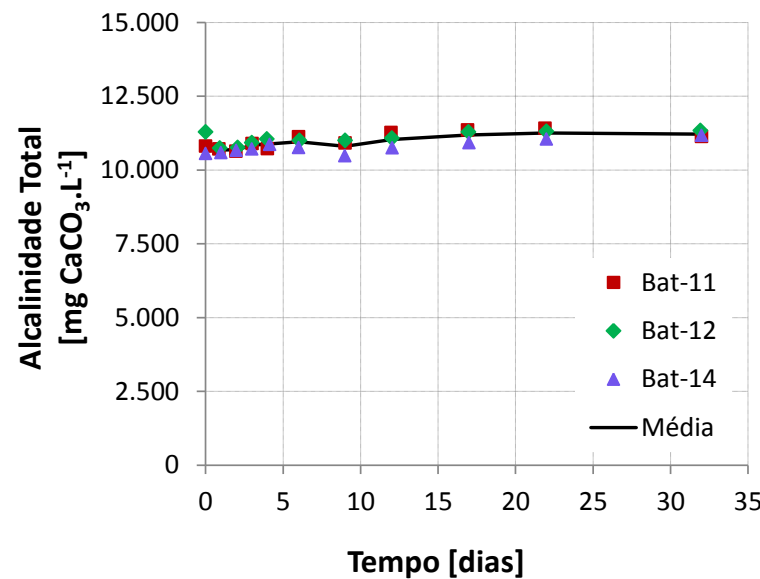

(d) Na Fase 3 a 24 ciclos por dia e $25^{\circ} \mathrm{C}$

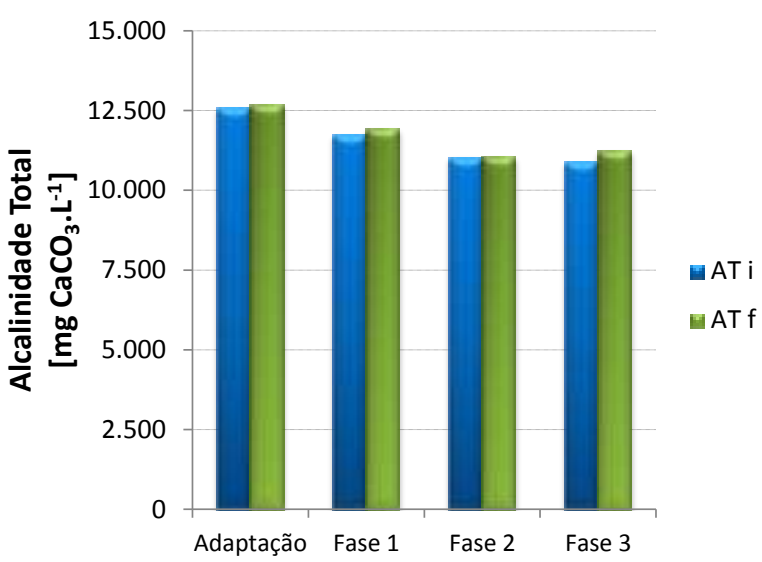

(f) Alcalinidade inicial e final nas quatro fases

Apesar da utilização de um volume maior de líquidos para recirculação/ operacionalização no sistema proposto, em comparação aos sistemas de uma única fase, citados na literatura, uma vantagem deste sistema seria apresentar intrinsicamente uma maior capacidade tampão, além de uma maior concentração de 
biomassa metanogênica, com riscos reduzidos de quedas relevantes nos valores de $\mathrm{pH}$, que de acordo Bouallagui et al. (2005), poderiam levar à interrupção da metanogênese, caso estes se aproximassem de 5,0.

Ao se avaliar as concentrações de ácidos voláteis totais no sistema (Figura 39), nota-se que na Fase de Adaptação os picos de acúmulo de ácidos ocorreram entre o segundo e o quinto dia de operação, atingindo-se concentrações da ordem de $2.800 \mathrm{mgAc} . \mathrm{L}^{-1}$, com uma queda considerável na batelada 04 (da ordem de 1.700 mgAc.. $\left.\mathrm{L}^{-1}\right)$, indicando uma possível estabilização e adaptação do sistema. Em

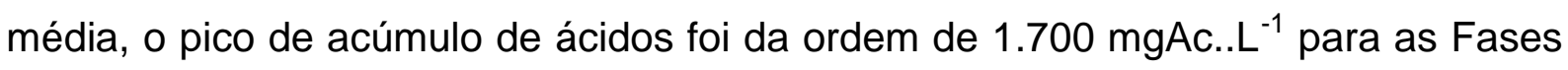
01 e 02 e de 1.500 mgAc.. $\mathrm{L}^{-1}$ para Fase 03.

Todavia, apesar dos picos de concentrações de ácidos observados, estes não foram suficientes para acidificação do sistema, o que responde à primeira das quatro questões levantadas no início deste item.

Como o sistema operou com altas taxas de recirculação de líquidos (12 e 24 ciclos por dia), a variação do $\mathrm{pH}$, AT e AVT entre os reatores hidrolítico e o filtro anaeróbio (amostradores A e B) pode ser considerada pouco relevante, pois as variações possuem as mesmas ordens de grandeza e ocorreram sem defasagens, como observado na Figura 40: (a) e (b) para pH, (c) e (d) para alcalinidade total e, (e) e (f) para ácidos voláteis totais. Dessa forma, devido à recirculação de líquidos, o conjunto de reatores se aproximou de um sistema de mistura completa.

Na Figura 41 e na Figura 42 são mostrados, respectivamente, os resultados de ácidos voláteis por cromatografia para as bateladas 05 (Fase 01) e 11 (Fase 03), onde é possível se observar que há predominância do ácido acético desde o início das bateladas, com maiores picos ocorrendo no segundo dia (95\% - 97\%), sendo desta forma, pouco relevante as concentrações dos demais ácidos voláteis. Tais resultados foram contrários aos obtidos por Picanço (2004) e Dillenburg (2006), que obtiveram concentrações de ácido propiônico e butírico da mesma ordem de grandeza das concentrações de ácido acético. Essa diferença pode ser devido ao fato de que, nos trabalhos citados, a inoculação foi feita somente com lixiviado, o que resultou em baixa concentração de biomassa no sistema, ocorrendo acúmulo de ácidos propiônico e butírico. 
Figura 39 - Variações das concentrações de Ácidos Voláteis Totais por titulação nas diferentes fases do experimento.

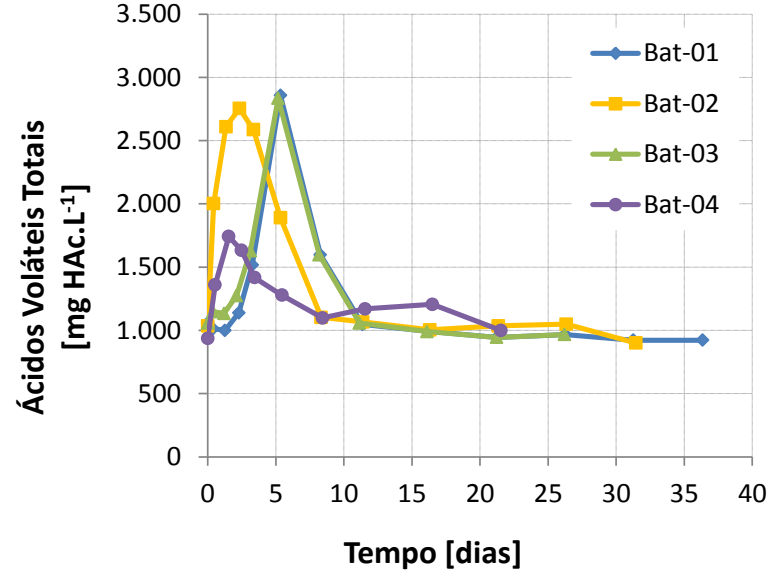

(a) Na Fase de Adaptação

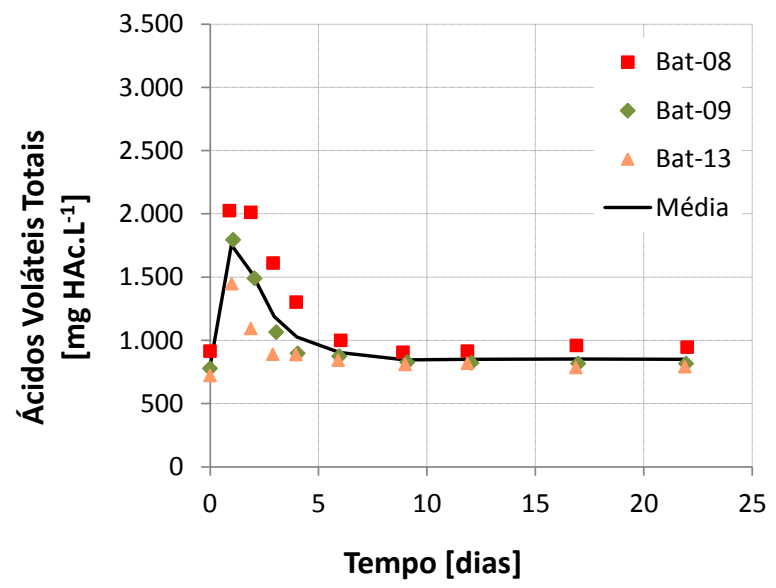

(c) Na Fase 2 a 24 ciclos por dia e $32^{\circ} \mathrm{C}$

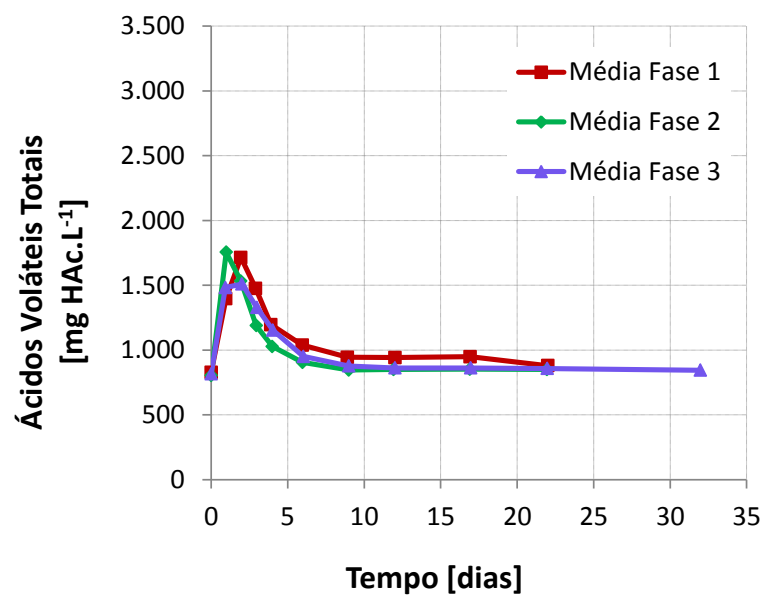

(e) Comparação entre as médias das Fases 1, 2 e 3

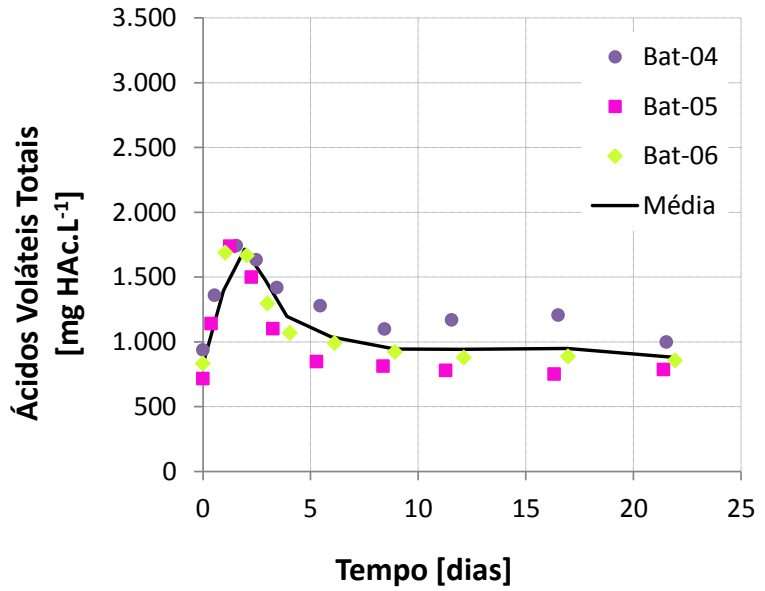

(b) Na Fase 1 a 12 ciclos por dia e $32^{\circ} \mathrm{C}$

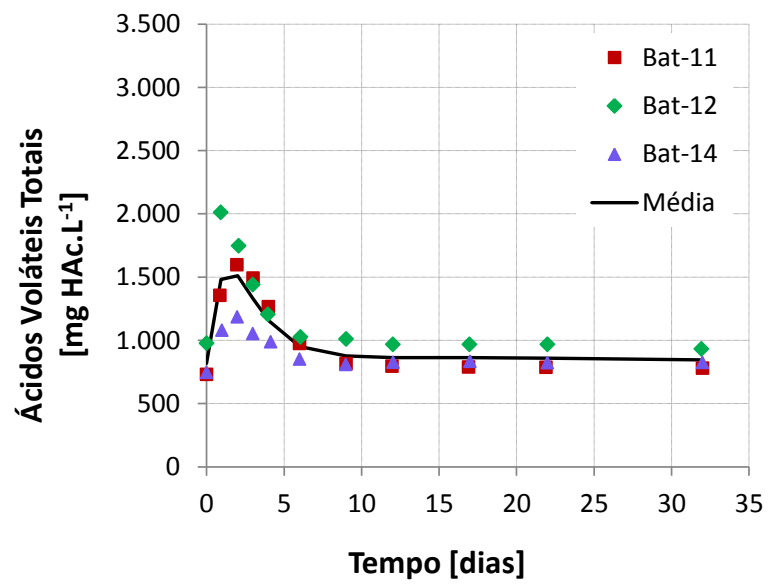

(d) Na Fase 3 a 24 ciclos por dia e $25^{\circ} \mathrm{C}$

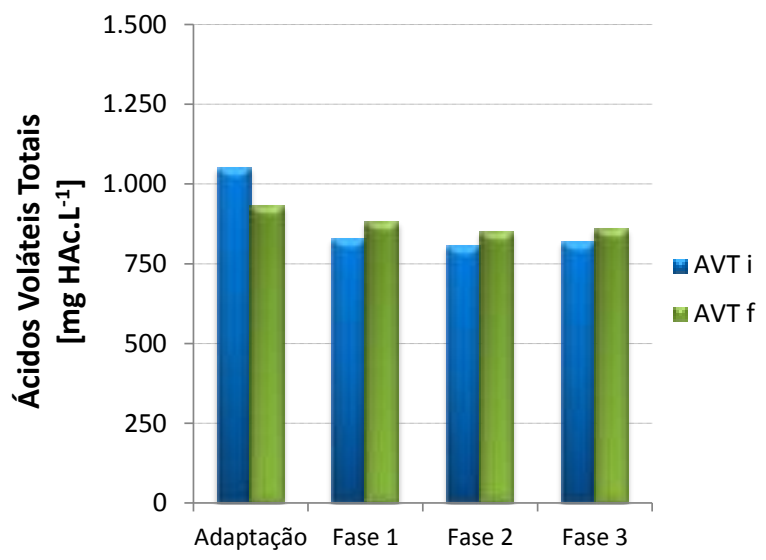

(f) Inicial e final nas quatro fases 
Figura 40 - Variações de parâmetros entre os amostradores A e $B^{*}$ : (a) pH Fase 01; (b) pH Fase 2; (c) AT Fase 1; (d) AT Fase 2; (e) AVT por titulação na Fase 1 e (f) AVT por titulação na Fase 2.

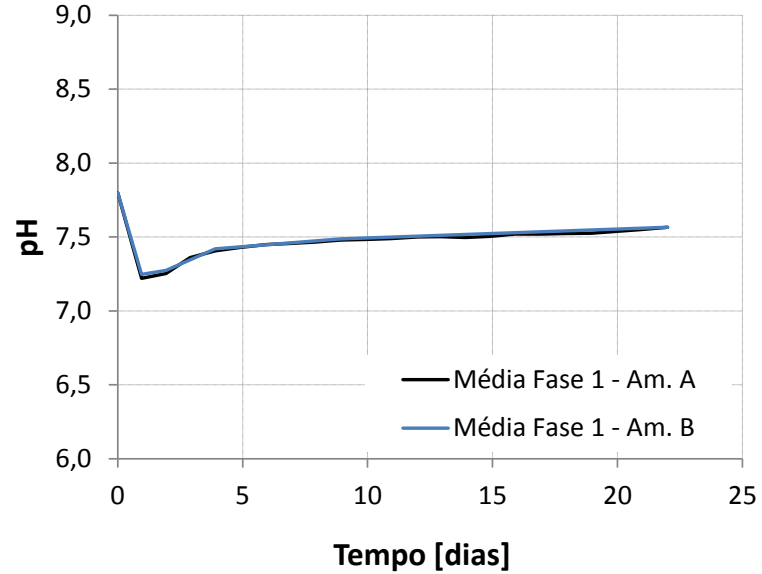

(a)

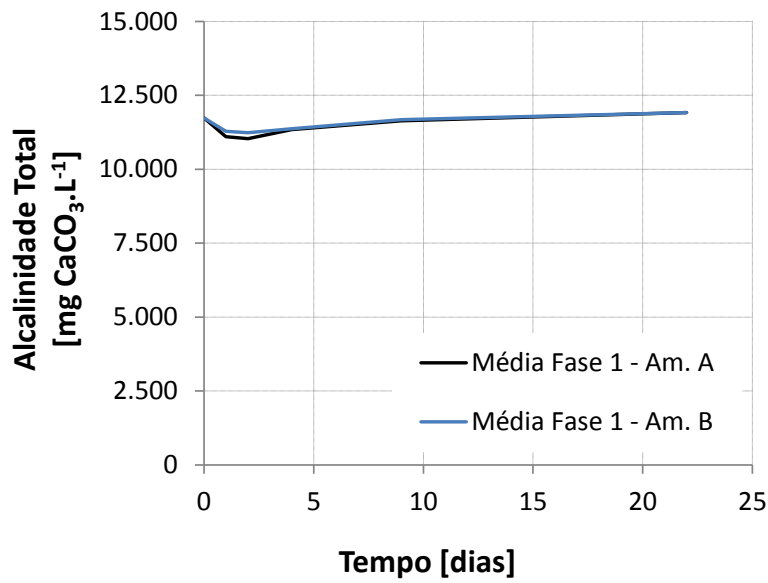

(c)

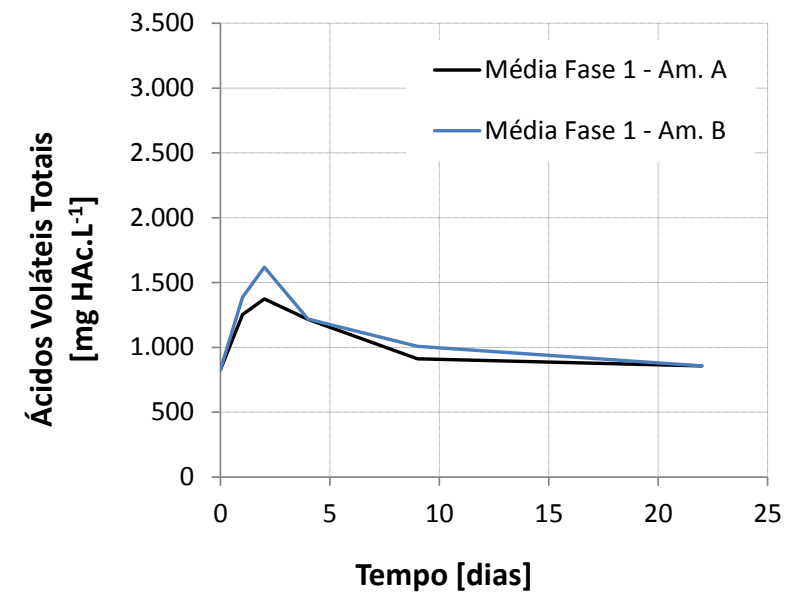

(e)

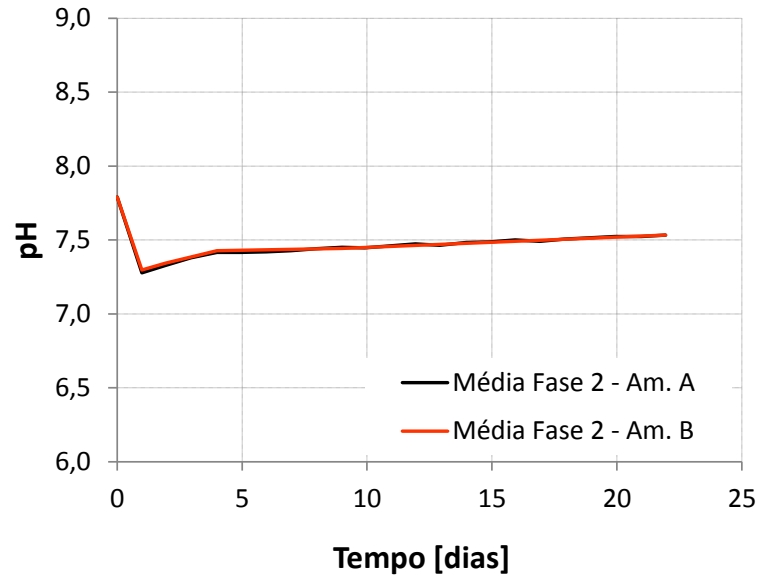

(b)

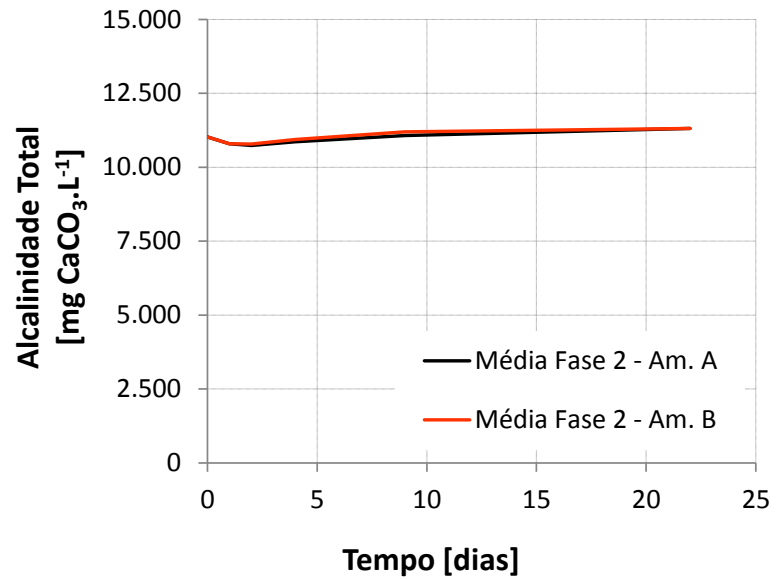

(d)

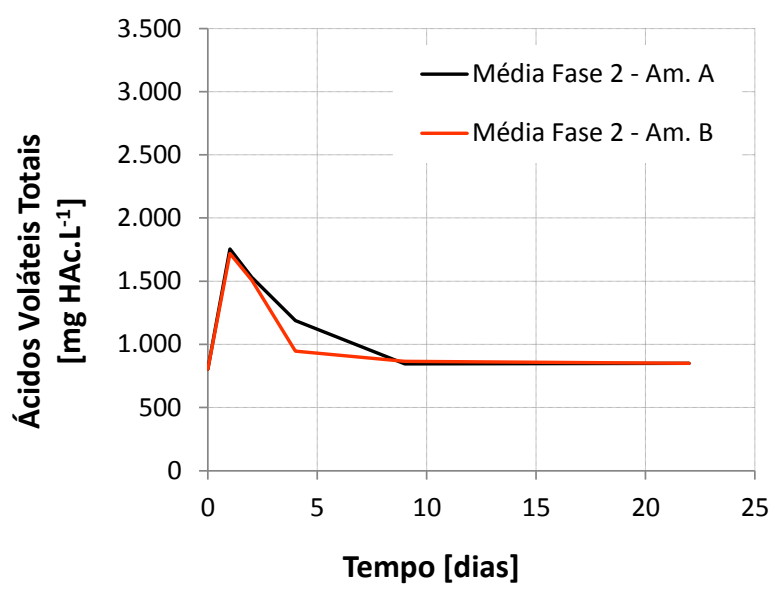

(f)

* Amostrador A, localizado após reator hidrolítico e amostrador B, localizado após filtro anaeróbio, conforme ilustrado na Figura 23. 
Figura 41 - Concentrações de ácidos voláteis por cromatografia de amostras coletadas nos amostradores A e $B^{*}$ na batelada 05 (Fase 01).

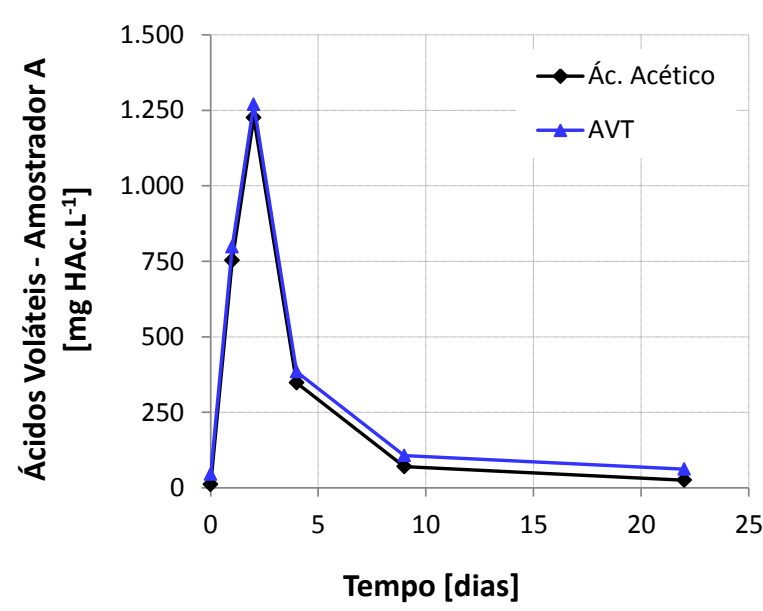

(a) Acido acético e AVT

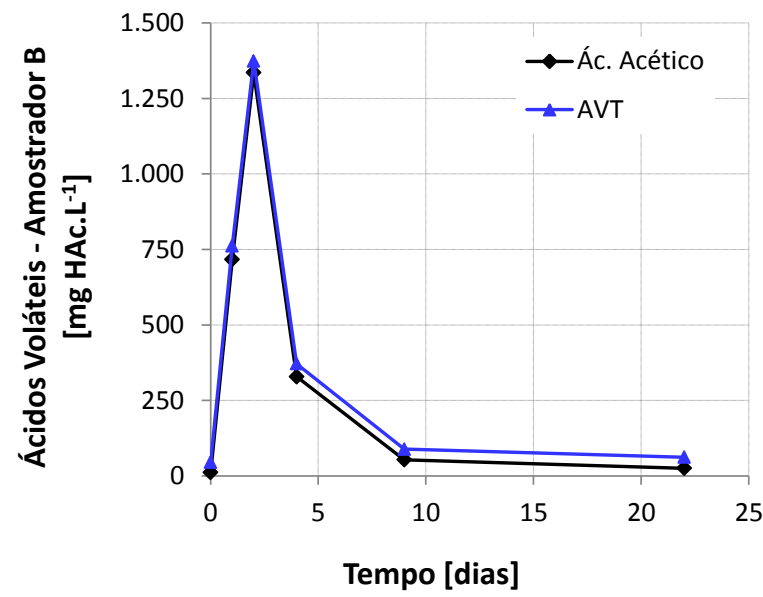

(c) Acido acético e AVT

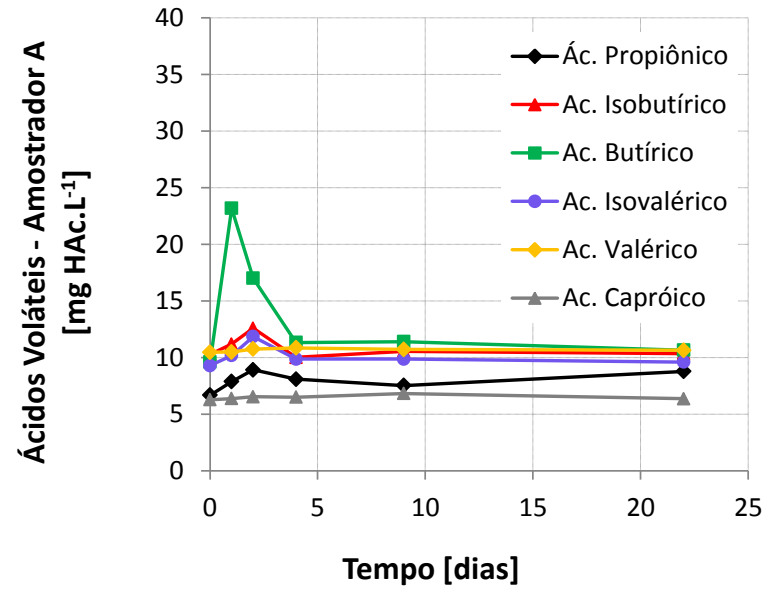

(b) Demais ácidos voláteis

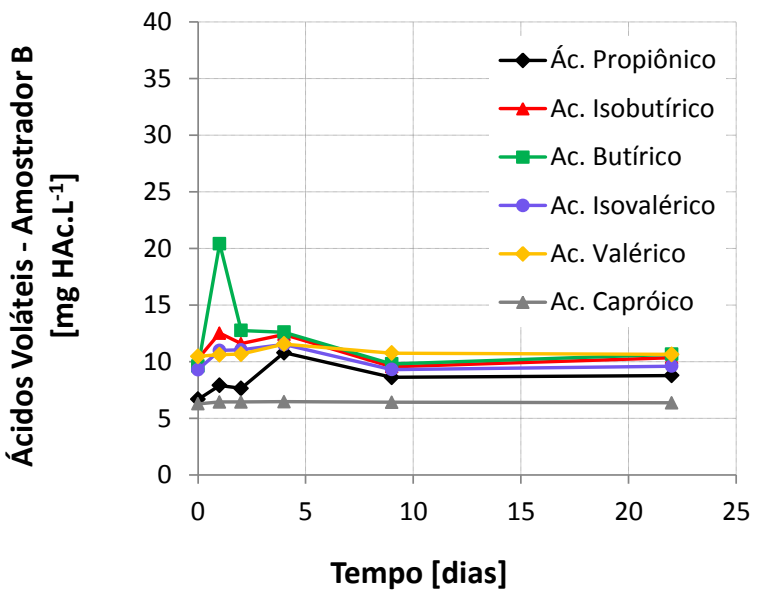

(d) Demais ácidos voláteis

* Amostrador A, localizado após reator hidrolítico e amostrador B, localizado após filtro anaeróbio, conforme ilustrado na Figura 23. 
Figura 42 - Concentrações de ácidos voláteis por cromatografia de amostras coletadas nos amostradores A e $B^{*}$ na batelada 11 (Fase 03).

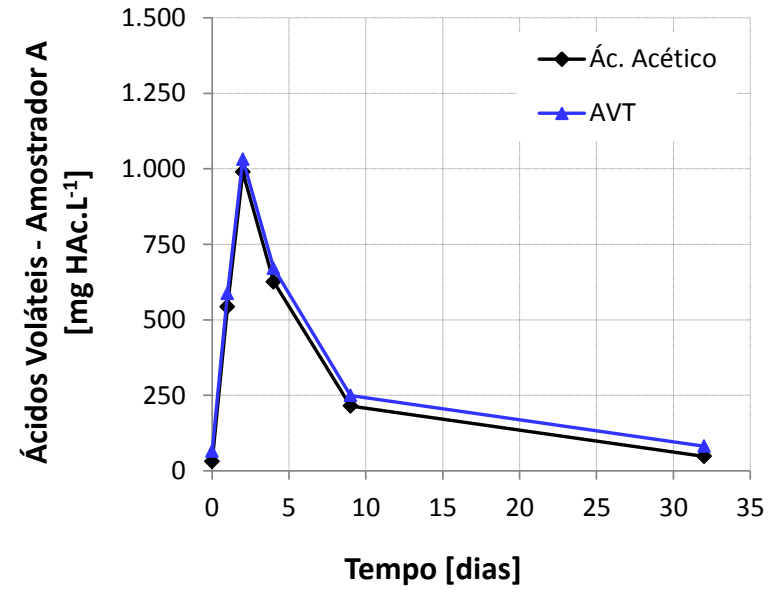

(a) Acido acético e AVT

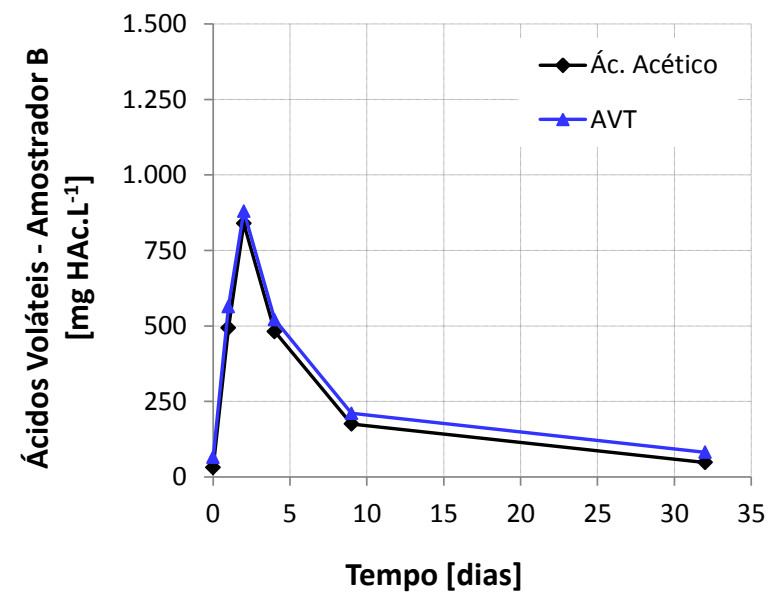

(c) Acido acético e AVT

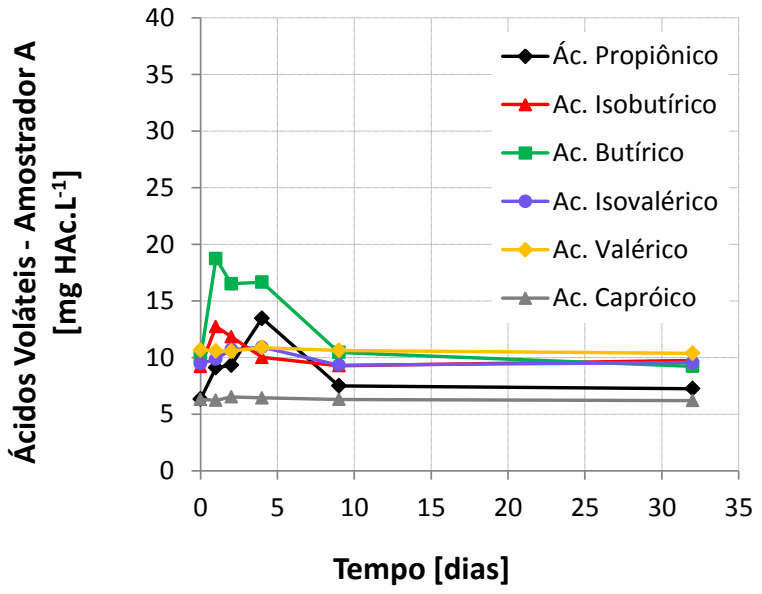

(b) Demais ácidos voláteis

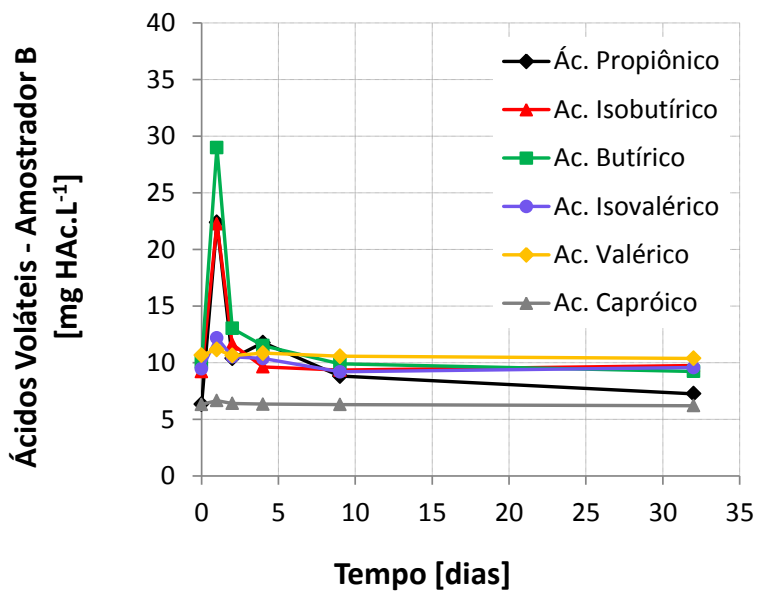

(d) Demais ácidos voláteis

* Amostrador A, localizado após reator hidrolítico e amostrador B, localizado após filtro anaeróbio, conforme ilustrado na Figura 23.

Com o objetivo de se responder à segunda questão anteriormente levantada, a respeito da efetividade do lixiviado como líquido de transporte para matéria orgânica solubilizada, foram avaliados os parâmetros ácidos voláteis totais, carbono orgânico total e sólidos dissolvidos voláteis, respectivamente ilustrados na Figura 39, Figura 43 e Figura 44.

Por essas figuras, nota-se que todos esses parâmetros apresentaram o mesmo padrão de comportamento, ou seja, as concentrações aumentam rapidamente nos três primeiros dias até se atingir um pico, o que indica solubilização e transferência de matéria orgânica da fase sólida para a líquida. Após este pico, com o predomínio do consumo desta matéria orgânica solubilizada, as concentrações tendem a decair 
mais lentamente até se atingir concentrações próximas às iniciais, no final das bateladas. Observa-se que os resultados de AVT e COT das Fases 02 e 03 foram ligeiramente inferiores aos das Fase 01, provavelmente devido ao aumento da taxa de recirculação.

Desta forma, conclui-se que o lixiviado cumpriu o seu propósito de ser um veículo de transporte para matéria orgânica solubilizada entre o reator hidrolítico e o filtro anaeróbio, uma vez que houve transferência de matéria orgânica da fase sólida do reator hidrolítico para fase líquida recirculada, que posteriormente era consumida no filtro anaeróbio.

Observando-se as concentrações iniciais e finais de COT e SDV, respectivamente mostrados na Figura 43 (f) e Figura 44 (f), verifica-se que existe pouca tendência de acúmulo dos mesmos, levando-se à conclusão de que provavelmente não está ocorrendo um acúmulo significativo de substâncias orgânicas recalcitrantes. Ainda de acordo com Contrera (2008), a quantificação dos ácidos voláteis totais por titulação, segundo a metodologia de DiLallo e Albertson (1961), apresenta como desvantagem a quantificação de interferentes, dentre os quais, alguns compostos recalcitrantes tais como ácidos húmicos e fúlvicos. Devido à quantificação destes interferentes nesta metodologia, as concentrações de AVT em lixiviados nunca chegam a zero. Aproveitando-se desta característica e observando-se as concentrações iniciais e finais de AVT na Figura 39 (f), pode-se notar o mesmo comportamento dos parâmetros COT e SDV, corroborando a conclusão supracitada, o que responde à terceira questão. 
Figura 43 - Variações das concentrações de Carbono Orgânico Total nas diferentes fases do experimento.

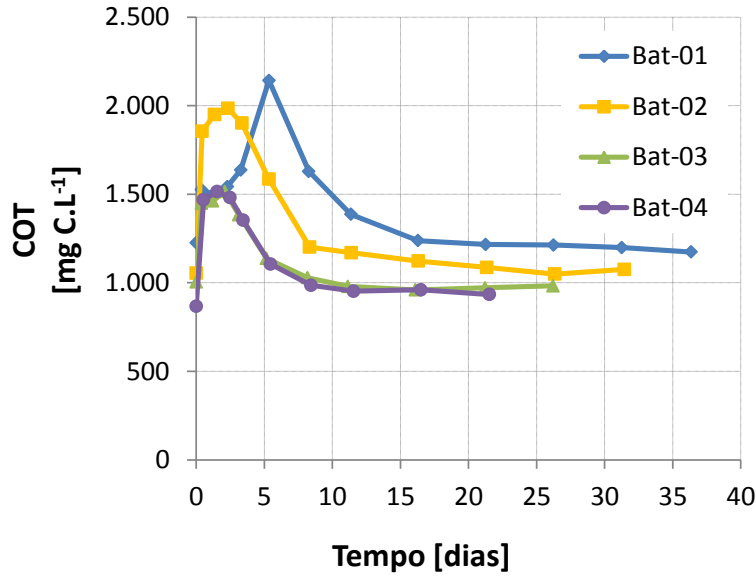

(a) Na Fase de Adaptação

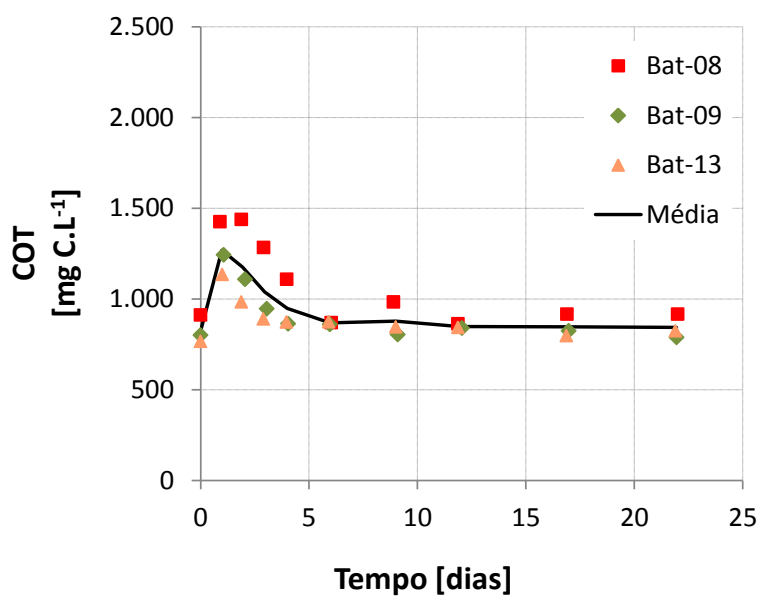

(c) Na Fase 2 a 24 ciclos por dia e $32^{\circ} \mathrm{C}$

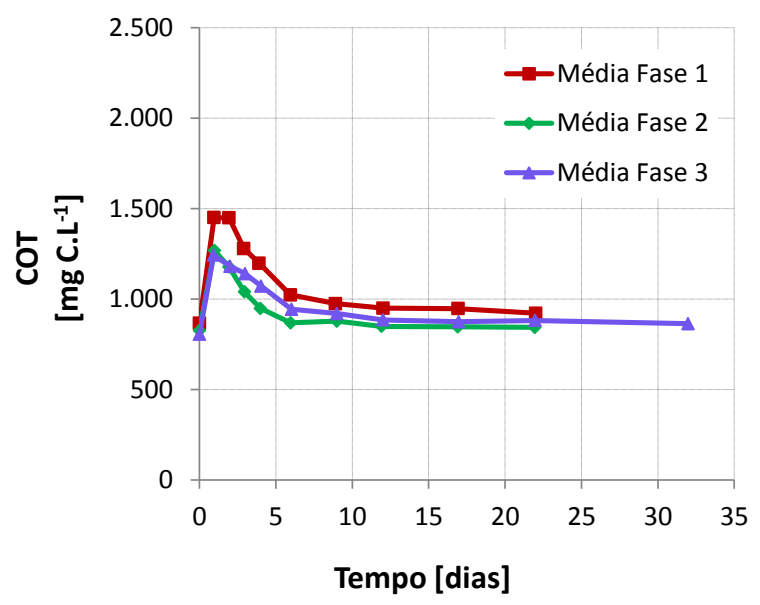

(e) Comparação entre as médias das Fases 1, 2 e 3

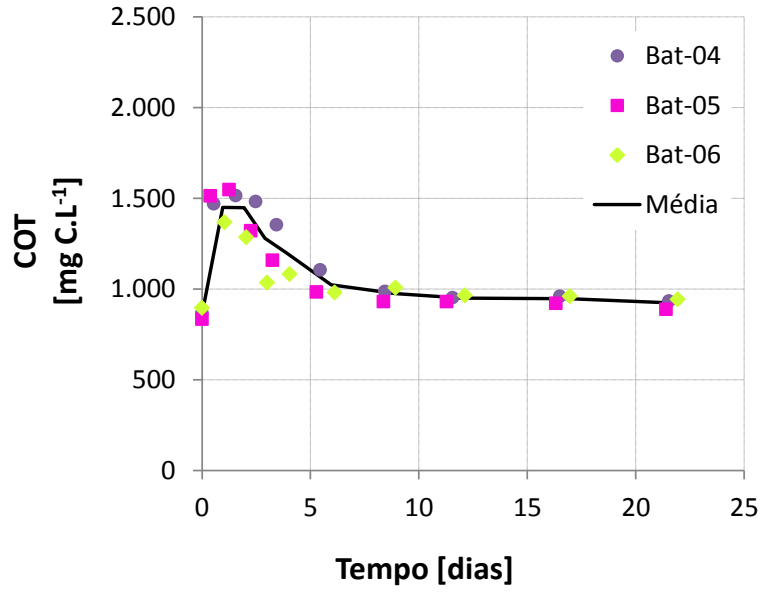

(b) Na Fase 1 a 12 ciclos por dia e $32^{\circ} \mathrm{C}$

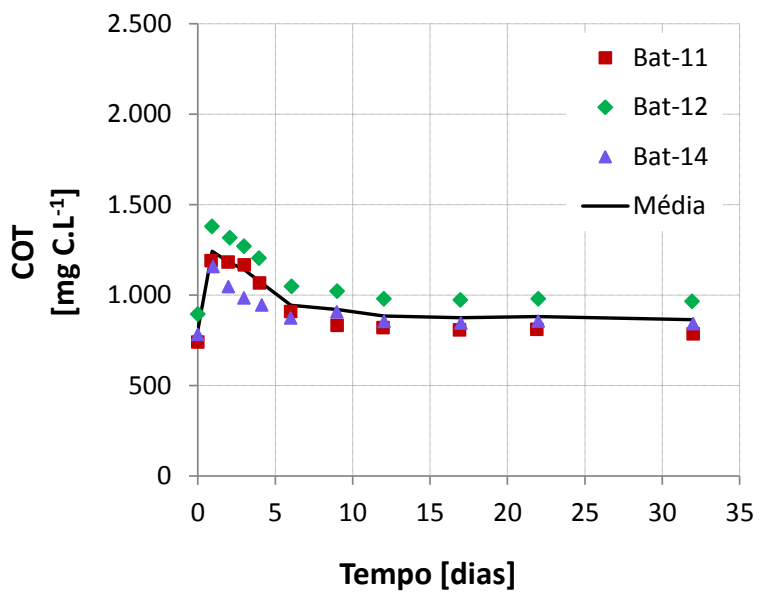

(d) Na Fase 3 a 24 ciclos por dia e $25^{\circ} \mathrm{C}$

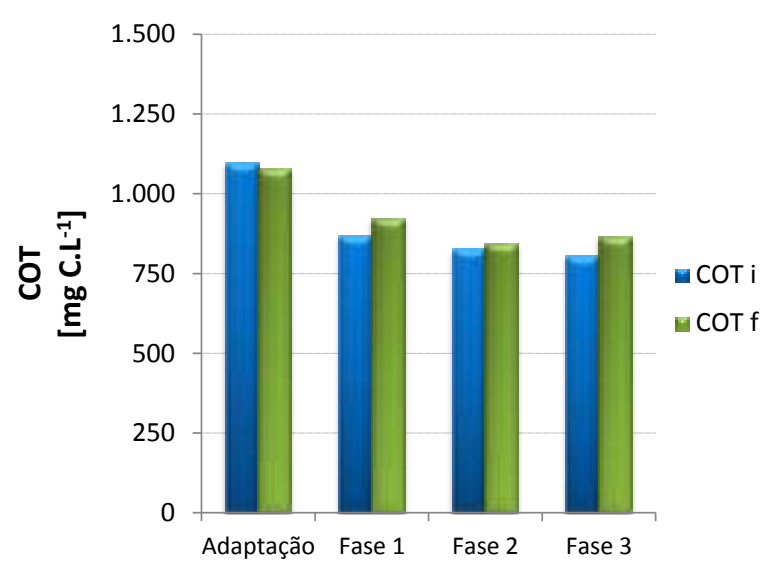

(f) Inicial e final nas quatro fases 
Figura 44 - Variações das concentrações de Sólidos Dissolvidos Voláteis nas diferentes fases do experimento.

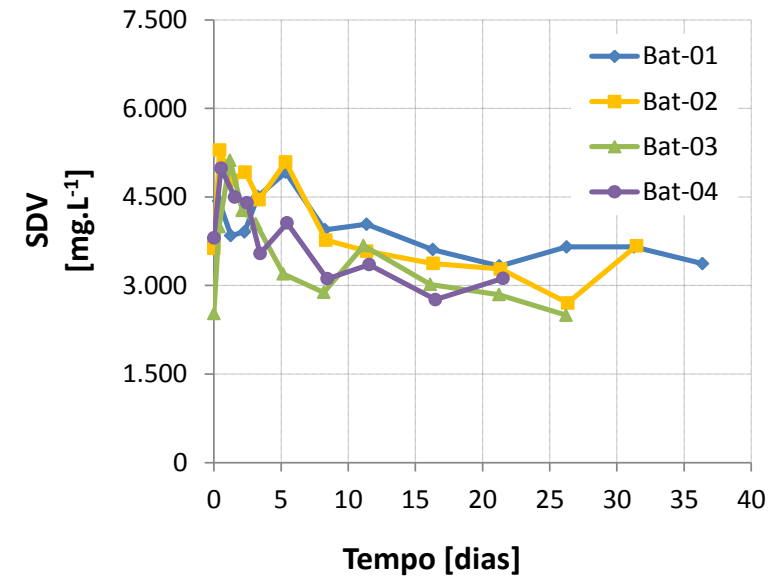

(a) Na Fase de Adaptação

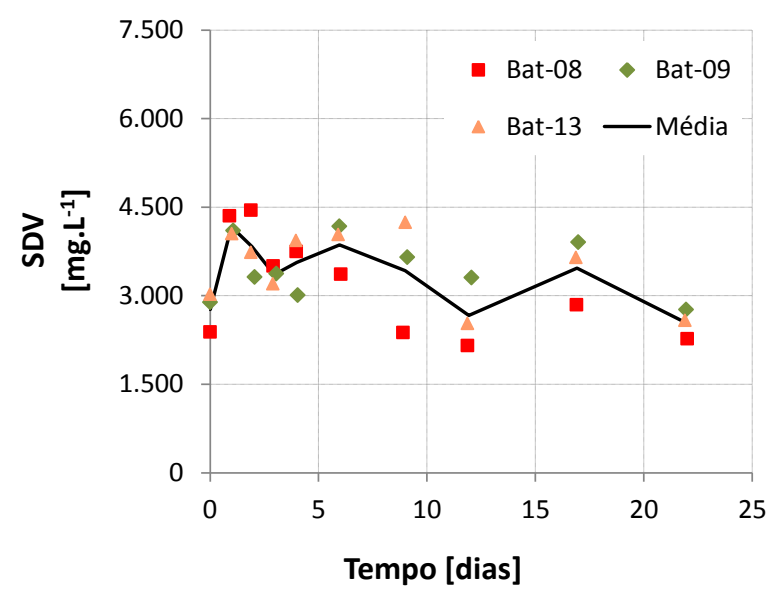

(c) Na Fase 2 a 24 ciclos por dia e $32^{\circ} \mathrm{C}$

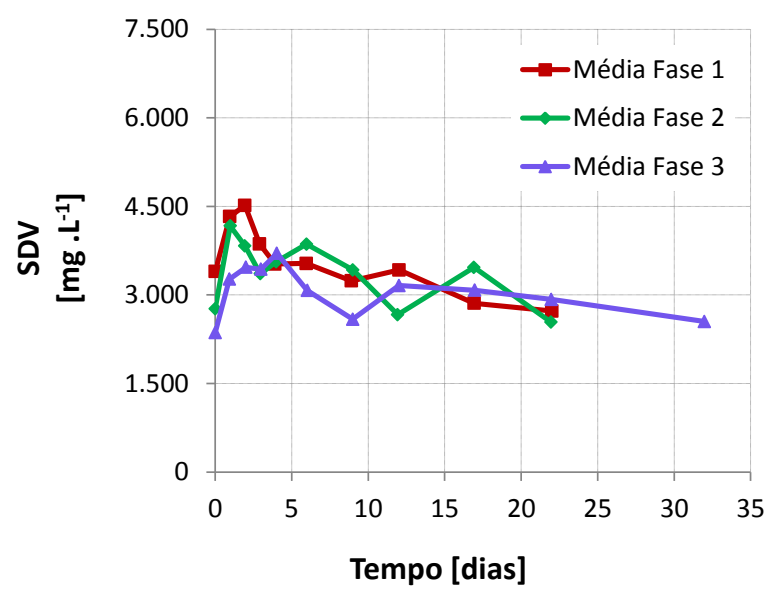

(e) Comparação entre as médias das Fases 1, 2 e 3

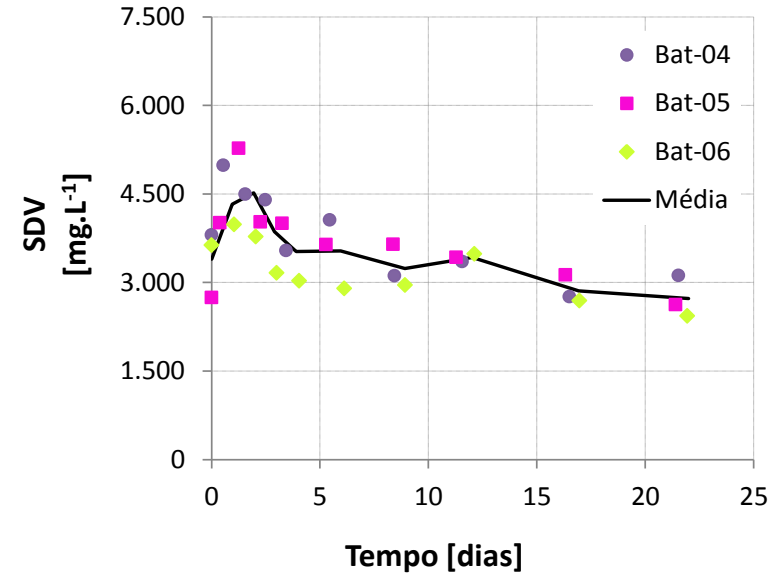

(b) Na Fase 1 a 12 ciclos por dia e $32^{\circ} \mathrm{C}$

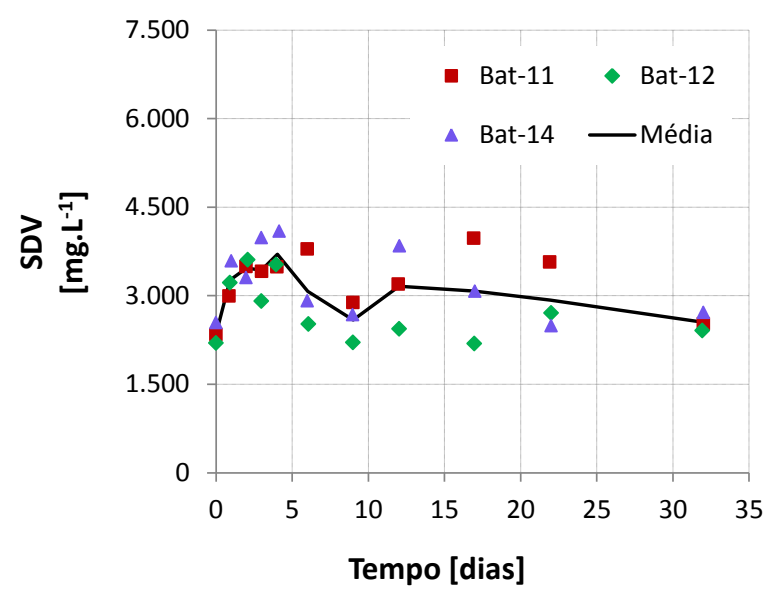

(d) Na Fase 3 a 24 ciclos por dia e $25^{\circ} \mathrm{C}$

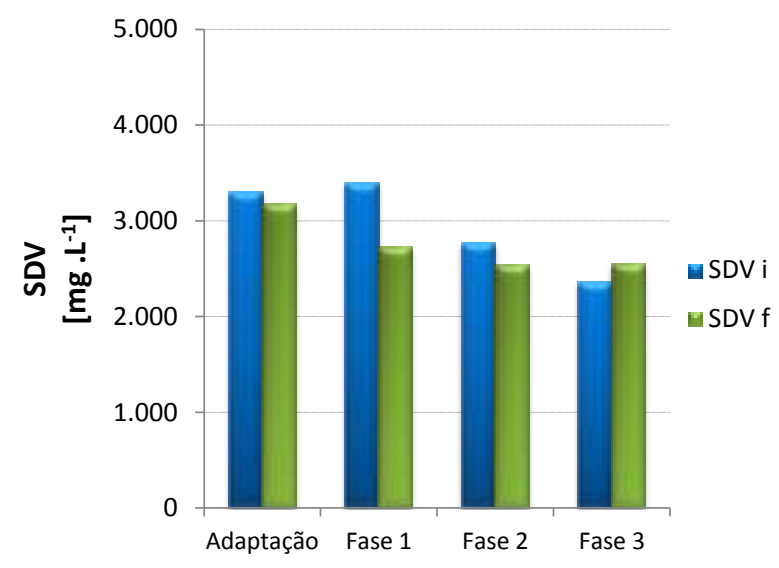

(f) Inicial e final nas quatro fases 
A última questão relacionada ao acúmulo de material inorgânico nos líquidos de recirculação, pode ser respondida ao se analisar a evolução da condutividade e das concentrações de SDF, de metais e de $\mathrm{N}$-amoniacal ao longo do tempo, ilustrados da Figura 59 a Figura 47.

Para esta análise serão levados em consideração somente os resultados das Fases 01,02 e 03 , onde ocorreu o reaproveitamento dos lixiviados para as bateladas subsequentes. Como base de comparação neste quesito, são apresentados os resultados da Fase de Adaptação, onde não ocorreu reutilização do lixiviado entre uma batelada e outra.

Nota-se pelas figuras relacionadas aos sólidos dissolvidos fixos, que os mesmos não apresentaram variações de concentrações relevantes ao longo das bateladas. $\mathrm{Da}$ mesma forma, a condutividade também permaneceu aproximadamente constante ao longo do tempo. Avaliando-se as concentrações de $\mathrm{N}$-amoniacal para as bateladas 06, 08 e12, verifica-se um acréscimo de 9,2\%; 7,5\% e 5,9\% nas concentrações entre o início e o fim das bateladas.

Assim, diante do exposto, e, observando-se as concentrações médias iniciais e finais destas variáveis nas quatro fases de operação, conclui-se que a reutilização dos lixiviados entre bateladas sucessivas não levou ao aumento significativo da salinidade do lixiviado. 
Figura 45 - Variações das concentrações de Sólidos Dissolvidos Fixo nas diferentes fases do experimentos.

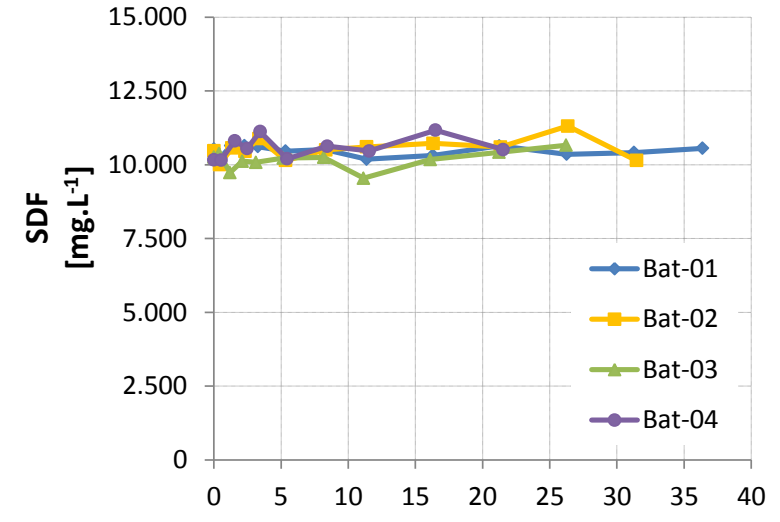

Tempo [dias]

(a) Na Fase de Adaptação

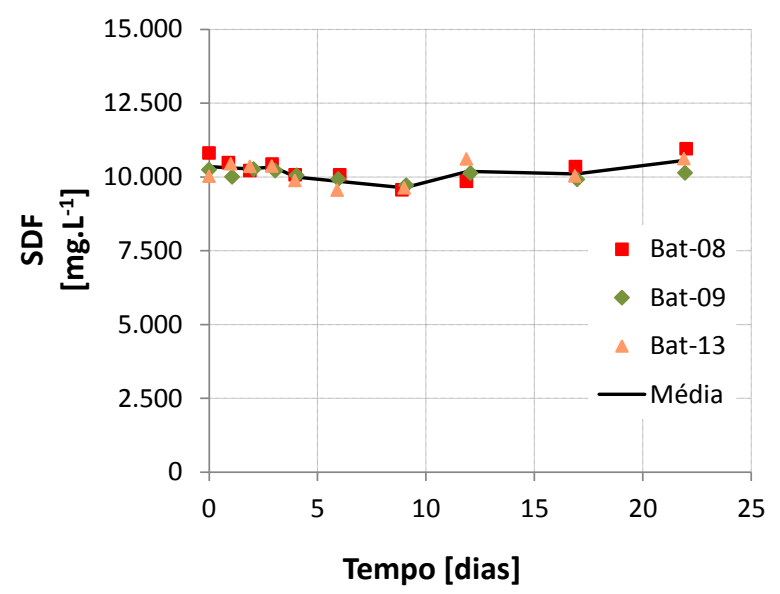

(c) Na Fase 2 a 24 ciclos por dia e $32^{\circ} \mathrm{C}$

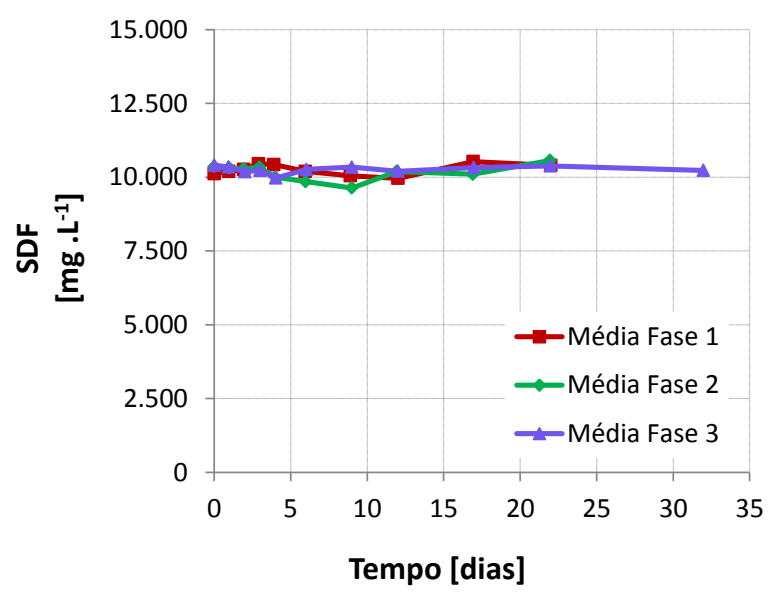

(e) Comparação entre as médias das Fases 1, 2 e 3

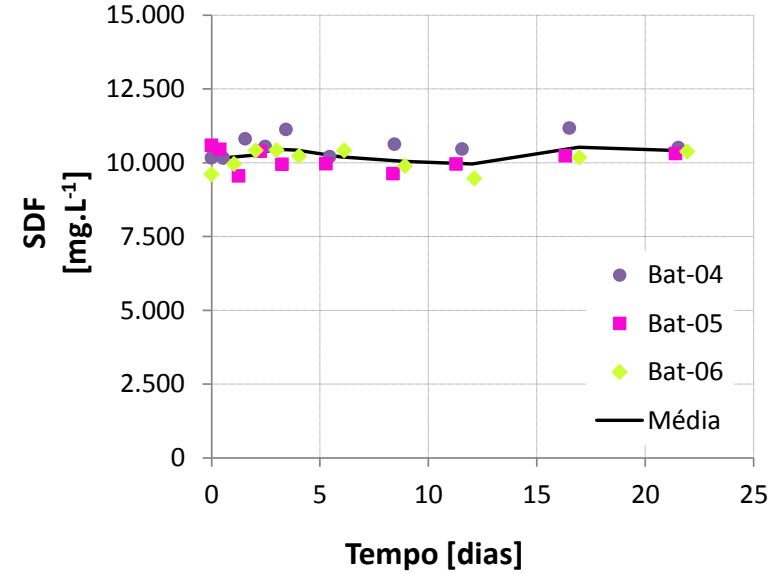

(b) Na Fase 1 a 12 ciclos por dia e $32^{\circ} \mathrm{C}$

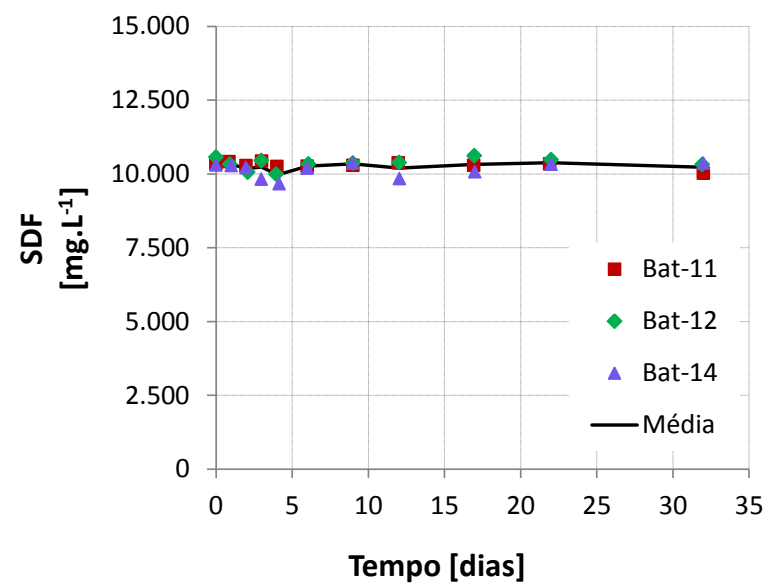

(d) Na Fase 3 a 24 ciclos por dia e $25^{\circ} \mathrm{C}$

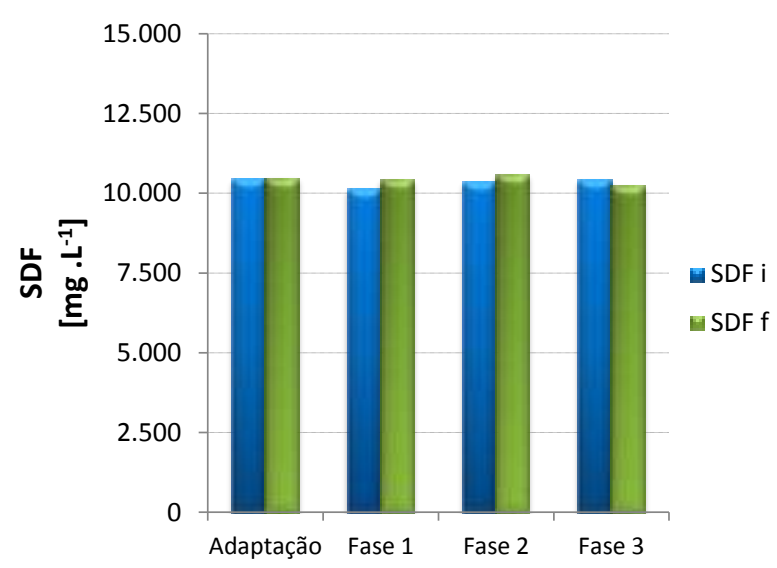

(f) Inicial e final nas quatro fases 
Figura 46 - Variações da Condutividade nas diferentes fases do experimento.

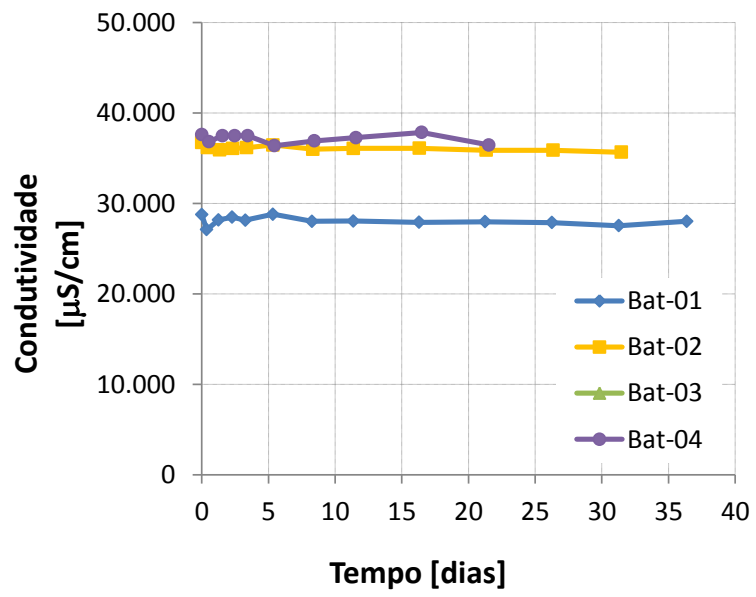

(a) Na Fase de Adaptação

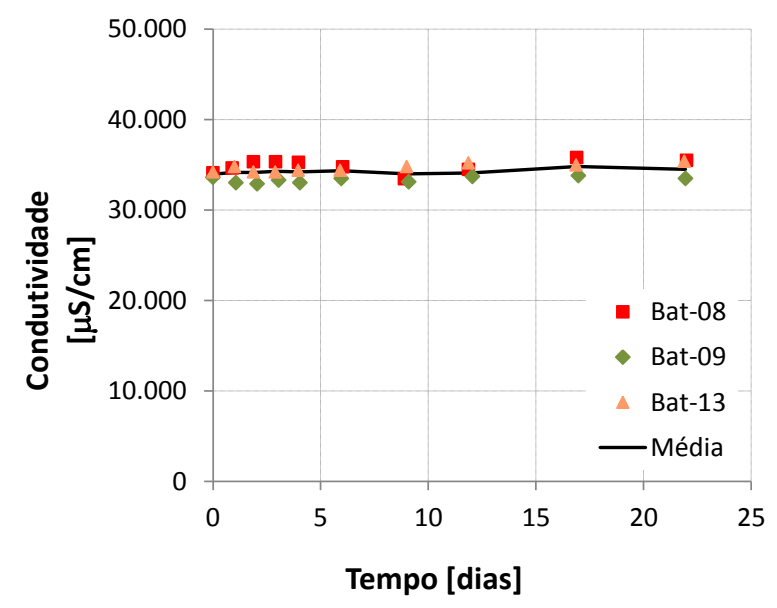

(c) Na Fase 2 a 24 ciclos por dia e $32^{\circ} \mathrm{C}$

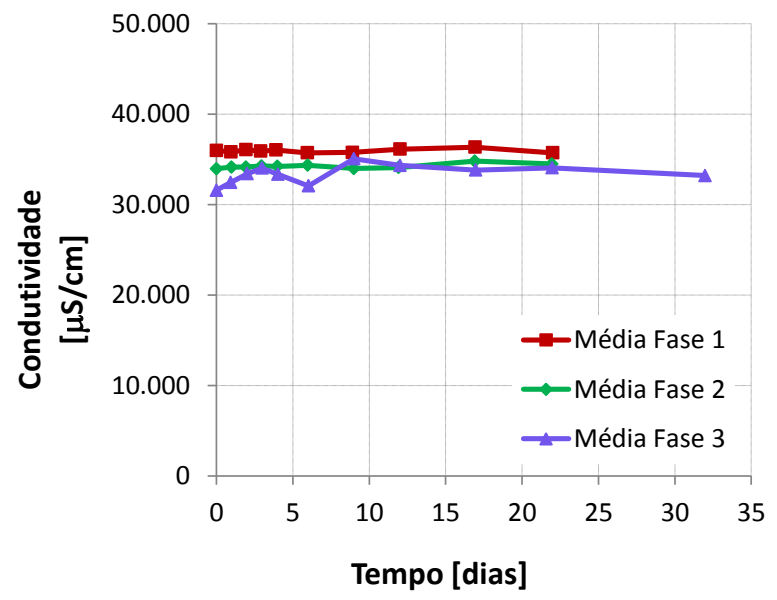

(e) Comparação entre as médias das Fases 1, 2 e 3

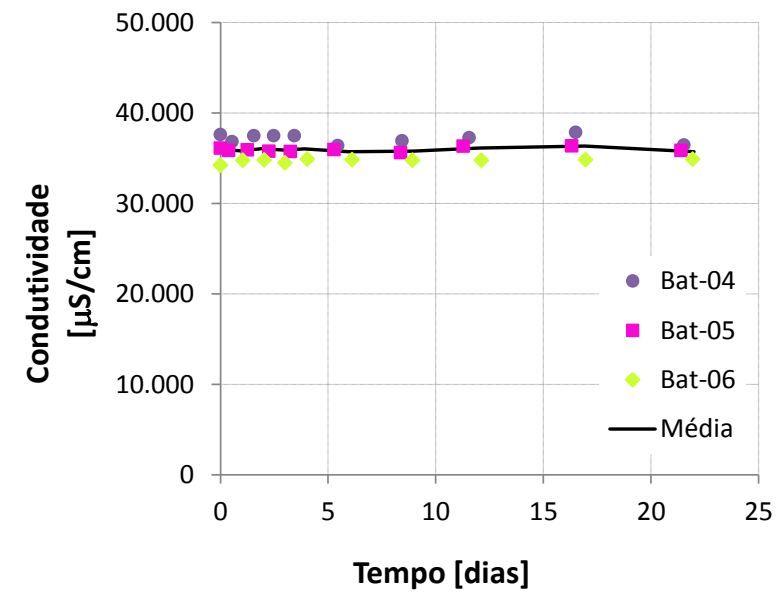

(b) Na Fase 1 a 12 ciclos por dia e $32^{\circ} \mathrm{C}$

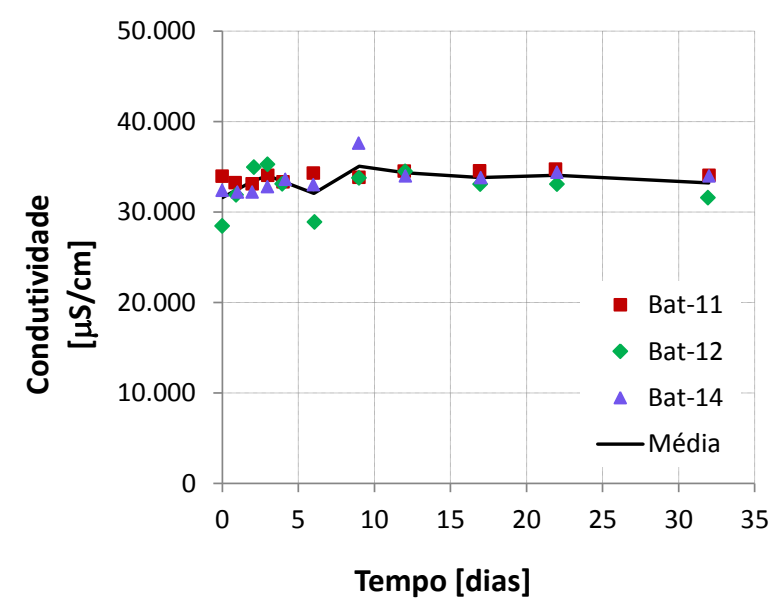

(d) Na Fase 3 a 24 ciclos por dia e $25^{\circ} \mathrm{C}$

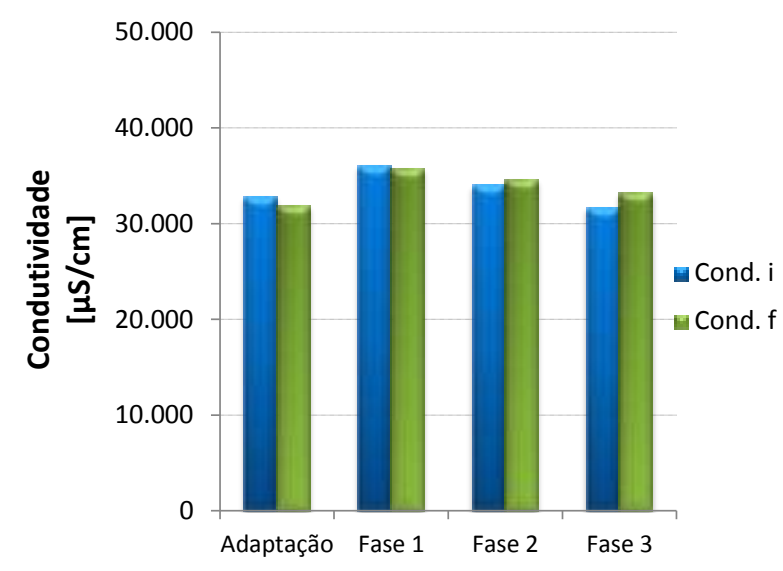

(f) Inicial e final nas quatro fases. 
Figura 47 - Variações das concentrações de N-amoniacal nas bateladas 06, 08 e 12.

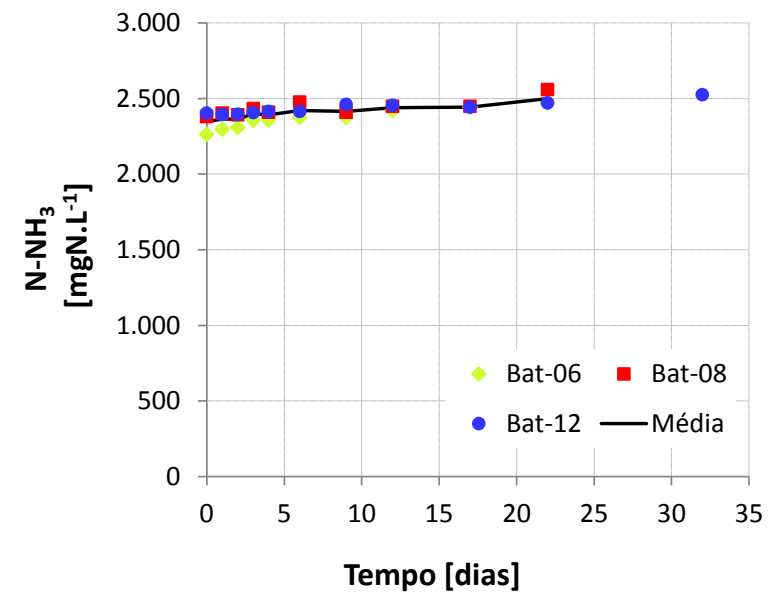

(a)

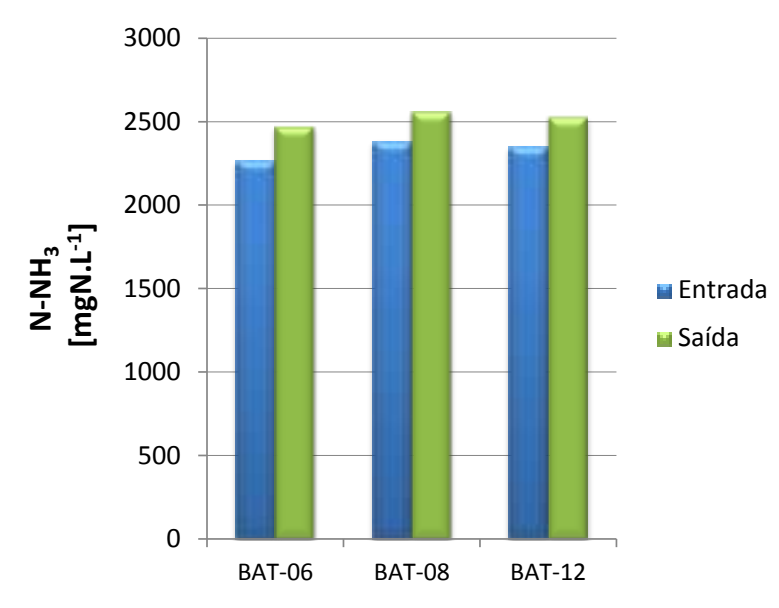

(b)

Com relação ao comportamento dos metais no líquido (Apêndice A), ocorreram muitas oscilações de concentração, provavelmente devido aos processos de adsorção e dessorção contínuos dos metais na matéria orgânica e na biomassa, que variam de acordo com as variações das condições do meio. Deste modo, não há como se concluir se houve ou não um aumento de concentração de metais no líquido recirculado.

Dessa forma, o uso de lixiviado de aterro sanitário mostrou-se viável como líquido de recirculação, devido à sua elevada alcalinidade e demais características compatíveis com as do resíduo tratado.

\subsection{Resíduo Sólido Tratado}

Dentre as principais questões relacionadas ao tratamento do resíduo sólido foram levantadas: 1) Houve diferença significativa de redução de massa entre as fases de operação do sistema? 2) Qual é a relação entre matéria orgânica e nutrientes no resíduo tratado? 3) As características do resíduo sólido tratado permitiriam seu uso na agricultura? 4) Apesar da separação das unidades de tratamento (hidrólise e metanogênese), houve colonização do resíduo no reator hidrolítico?

Buscando-se verificar a redução da massa de resíduos em cada fase operacional, foi realizada uma caracterização do resíduo cru em duplicata (Tabela 29) e dos resíduos tratados em cada batelada, separadas por fases (Tabela 30 a Tabela 33). 
Tabela 29 - Caracterização dos resíduos crus em termos de sólidos.

\begin{tabular}{|c|c|c|c|c|c|c|c|}
\hline \multirow{2}{*}{ Amostra } & \multirow{2}{*}{ Unidade } & \multicolumn{5}{|c|}{ Parâmetros } & \multirow{2}{*}{ STV/ST } \\
\hline & & Resíduo & Água & ST & STF & STV & \\
\hline \multirow[t]{2}{*}{05 (cru) } & massa $[\mathrm{g}]$ & 410,30 & 337,00 & 73,30 & 5,42 & 67,88 & 0,926 \\
\hline & fração [\%] & $(100 \%)$ & $(82,14 \%)$ & $(17,86 \%)$ & $(1,32 \%)$ & $(16,54 \%)$ & \\
\hline \multirow[t]{2}{*}{12 (cru) } & massa [g] & 354,55 & 274,99 & 79,56 & 5,70 & 73,86 & 0,928 \\
\hline & fração [\%] & $(100 \%)$ & $(67,02 \%)$ & $(19,39 \%)$ & $(1,39 \%)$ & $(18,00 \%)$ & \\
\hline \multirow[t]{2}{*}{ Média* } & massa [g] & 382,43 & 305,99 & 76,43 & 5,56 & 70,87 & 0,927 \\
\hline & fração [\%] & (100\%) & (74,58\%) & $(18,63 \%)$ & $(1,35 \%)$ & $(17,27 \%)$ & \\
\hline
\end{tabular}

*Valores adotados como referência para os resíduos crus (antes do tratamento).

Tabela 30 - Caracterização dos resíduos crus e tratados, e eficiências de remoção na Fase de Adaptação (32 ${ }^{\circ} \mathrm{C}$ e $\left.12 \mathrm{X}\right)$.

\begin{tabular}{|c|c|c|c|c|c|c|c|c|}
\hline \multirow{2}{*}{ Batelada } & \multirow{2}{*}{ Amostra } & \multirow{2}{*}{ Unidade } & \multicolumn{5}{|c|}{ Parâmetros } & \multirow{2}{*}{ STV/ST } \\
\hline & & & Resíduo & Água & ST & STF & STV & \\
\hline \multirow{5}{*}{01} & 09 (cru) & massa [g] & 410,25 & 333,82 & 76,43 & 5,56 & 70,87 & 0,927 \\
\hline & & fração [\%] & $(100 \%)$ & 81,37 & 18,63 & 1,36 & 17,28 & \\
\hline & 09 (dig.) & massa [g] & 77,95 & 66,69 & 11,23 & 2,85 & 8,38 & 0,747 \\
\hline & & fração [\%] & $(100 \%)$ & 85,56 & 14,40 & 3,65 & 10,75 & \\
\hline & Redução & [\%] & 81,00 & 80,02 & 85,31 & 48,83 & 88,18 & 19,49 \\
\hline \multirow{5}{*}{02} & 03 (cru) & massa $[\mathrm{g}]$ & 412,65 & 336,22 & 76,43 & 5,56 & 70,87 & 0,927 \\
\hline & & fração [\%] & $(100 \%)$ & 81,48 & 18,52 & 1,35 & 17,17 & \\
\hline & 03 (dig.) & massa $[\mathrm{g}]$ & 88,75 & 72,67 & 18,90 & 3,76 & 15,13 & 0,801 \\
\hline & & fração [\%] & $(100 \%)$ & 81,88 & 21,29 & 4,24 & 17,05 & \\
\hline & Redução & [\%] & 78,49 & 78,39 & 75,28 & 32,31 & 78,65 & 13,63 \\
\hline \multirow{5}{*}{03} & 07 (cru) & massa [g] & 411,45 & 335,02 & 76,43 & 5,56 & 70,87 & 0,927 \\
\hline & & fração [\%] & $(100 \%)$ & 81,42 & 18,58 & 1,35 & 17,22 & \\
\hline & 07 (dig.) & massa [g] & 84,02 & 69,90 & 8,79 & 2,39 & 6,40 & 0,728 \\
\hline & & fração [\%] & $(100 \%)$ & 83,20 & 10,46 & 2,84 & 7,61 & \\
\hline & Redução & [\%] & 79,58 & 79,13 & 88,50 & 57,01 & 90,97 & 21,49 \\
\hline \multirow{5}{*}{04} & 13 (cru) & massa $[\mathrm{g}]$ & 413,75 & 337,32 & 76,43 & 5,56 & 70,87 & 0,927 \\
\hline & & fração [\%] & $(100 \%)$ & 81,53 & 18,47 & 1,34 & 17,13 & \\
\hline & 13 (dig.) & massa $[\mathrm{g}]$ & 96,82 & 82,09 & 16,73 & 4,13 & 12,59 & 0,753 \\
\hline & & fração [\%] & $(100 \%)$ & 84,79 & 17,28 & 4,27 & 13,01 & \\
\hline & Redução & [\%] & 76,60 & 75,66 & 78,11 & 25,63 & 82,23 & 18,81 \\
\hline \multirow{5}{*}{ Média } & $09,03,07$ e 13 & massa $[\mathrm{g}]$ & 412,03 & 335,59 & 76,43 & 5,56 & 70,87 & 0,927 \\
\hline & (cru) & fração [\%] & $(100 \%)$ & 81,45 & 18,55 & 1,35 & 17,20 & \\
\hline & $09,03,07$ e 13 & massa $[\mathrm{g}]$ & 86,88 & 72,84 & 13,91 & 3,28 & 10,63 & 0,757 \\
\hline & (cru) & fração [\%] & $(100 \%)$ & 83,86 & 15,86 & 3,75 & 12,11 & \\
\hline & Redução & [\%] & 78,91 & 78,30 & 81,80 & 40,95 & 85,01 & 18,35 \\
\hline
\end{tabular}


Tabela 31 - Caracterização dos resíduos crus e tratados, e eficiências de remoção na Fase $01\left(32^{\circ} \mathrm{C}\right.$ e $\left.12 \mathrm{X}\right)$.

\begin{tabular}{|c|c|c|c|c|c|c|c|c|}
\hline \multirow{2}{*}{ Batelada } & \multirow{2}{*}{ Amostra } & \multirow{2}{*}{ Unidade } & \multicolumn{5}{|c|}{ Parâmetros } & \multirow{2}{*}{ STV/ST } \\
\hline & & & Resíduo & Água & ST & STF & STV & \\
\hline \multirow{5}{*}{04} & 13 (cru) & massa $[\mathrm{g}]$ & 413,75 & 337,32 & 76,43 & 5,56 & 70,87 & 0,927 \\
\hline & & fração [\%] & $(100 \%)$ & 81,53 & 18,47 & 1,34 & 17,13 & \\
\hline & 13 (dig.) & massa $[\mathrm{g}]$ & 96,82 & 82,09 & 16,73 & 4,13 & 12,59 & 0,753 \\
\hline & & fração [\%] & $(100 \%)$ & 84,79 & 17,28 & 4,27 & 13,01 & \\
\hline & Redução & [\%] & 76,60 & 75,66 & 78,11 & 25,63 & 82,23 & 18,81 \\
\hline \multirow{5}{*}{05} & 14 (cru) & massa $[\mathrm{g}]$ & 415,30 & 338,87 & 76,43 & 5,56 & 70,87 & 0,927 \\
\hline & & fração [\%] & $(100 \%)$ & 81,60 & 18,40 & 1,34 & 17,07 & \\
\hline & 14 (dig.) & massa $[\mathrm{g}]$ & 100,93 & 83,72 & 19,55 & 4,49 & 15,06 & 0,770 \\
\hline & & fração [\%] & (100\%) & 82,96 & 19,37 & 4,45 & 14,92 & \\
\hline & Redução & [\%] & 75,70 & 75,29 & 74,43 & 19,22 & 78,76 & 16,93 \\
\hline \multirow{5}{*}{06} & 11 (cru) & massa $[\mathrm{g}]$ & 414,75 & 338,32 & 76,43 & 5,56 & 70,87 & 0,927 \\
\hline & & fração [\%] & $(100 \%)$ & 81,57 & 18,43 & 1,34 & 17,09 & \\
\hline & 11 (dig.) & massa [g] & 109,76 & 92,16 & 18,71 & 4,76 & 13,95 & 0,746 \\
\hline & & fração [\%] & $(100 \%)$ & 83,96 & 17,05 & 4,34 & 12,71 & \\
\hline & Redução & {$[\%]$} & 73,54 & 72,76 & 75,52 & 14,36 & 80,32 & 19,60 \\
\hline \multirow{5}{*}{$\begin{array}{l}\text { Média } \\
\text { Fase } 1\end{array}$} & 13,14 e 11 & massa $[\mathrm{g}]$ & 414,60 & 338,17 & 76,43 & 5,56 & 70,87 & 0,927 \\
\hline & (cru) & fração [\%] & (100\%) & 81,57 & 18,43 & 1,34 & 17,09 & \\
\hline & 13,14 e 11 & massa $[\mathrm{g}]$ & 102,50 & 85,99 & 18,33 & 4,46 & 13,87 & 0,756 \\
\hline & (dig.) & fração [\%] & (100\%) & 83,90 & 17,90 & 4,35 & 13,55 & \\
\hline & Redução & [\%] & 75,28 & 74,57 & 76,02 & 19,74 & 80,43 & 18,45 \\
\hline
\end{tabular}

Tabela 32 - Caracterização dos resíduos crus e tratados, e eficiências de remoção na Fase 02 $32^{\circ} \mathrm{C}$ e $24 X$ (continua).

\begin{tabular}{|c|c|c|c|c|c|c|c|c|}
\hline \multirow{2}{*}{ Batelada } & \multirow{2}{*}{ Amostra } & \multirow{2}{*}{ Unidade } & \multicolumn{5}{|c|}{ Parâmetros } & \multirow{2}{*}{ STV/ST } \\
\hline & & & Resíduo & Água & ST & STF & STV & \\
\hline \multirow{5}{*}{08} & \multirow[t]{2}{*}{16 (cru) } & massa [g] & 410,30 & 333,87 & 76,43 & 5,56 & 70,87 & \multirow[t]{2}{*}{0,927} \\
\hline & & fração [\%] & $(100 \%)$ & 81,37 & 18,63 & 1,35 & 17,27 & \\
\hline & \multirow[t]{2}{*}{16 (dig.) } & massa [g] & 111,04 & 92,41 & 18,54 & 3,75 & 14,79 & \multirow[t]{2}{*}{0,798} \\
\hline & & fração [\%] & $(100 \%)$ & 83,23 & 16,70 & 3,38 & 13,32 & \\
\hline & Redução & [\%] & 72,94 & 72,32 & 75,74 & 32,53 & 79,13 & 13,98 \\
\hline \multirow{5}{*}{09} & \multirow[t]{2}{*}{02 (cru) } & massa [g] & 405,95 & 329,52 & 76,43 & 5,56 & 70,87 & \multirow[t]{2}{*}{0,927} \\
\hline & & fração [\%] & $(100 \%)$ & 81,17 & 18,83 & 1,37 & 17,46 & \\
\hline & \multirow[t]{2}{*}{02 (dig.) } & massa [g] & 111,39 & 92,30 & 18,84 & 4,05 & 14,78 & \multirow[t]{2}{*}{0,785} \\
\hline & & fração [\%] & (100\%) & 82,87 & 16,91 & 3,64 & 13,27 & \\
\hline & Redução & [\%] & 72,56 & 71,99 & 75,36 & 27,08 & 79,14 & 15,37 \\
\hline \multirow{5}{*}{13} & \multirow[t]{2}{*}{17 (cru) } & massa [g] & 405,30 & 328,87 & 76,43 & 5,56 & 70,87 & \multirow[t]{2}{*}{0,927} \\
\hline & & fração [\%] & $(100 \%)$ & 81,14 & 18,86 & 1,37 & 17,49 & \\
\hline & \multirow[t]{2}{*}{17 (dig.) } & massa [g] & 94,36 & 77,85 & 18,85 & 3,98 & 14,87 & \multirow[t]{2}{*}{0,789} \\
\hline & & fração [\%] & $(100 \%)$ & 82,50 & 19,98 & 4,21 & 15,76 & \\
\hline & Redução & [\%] & 76,72 & 76,33 & 75,34 & 28,49 & 79,01 & 14,90 \\
\hline
\end{tabular}


Tabela 32 - Caracterização dos resíduos crus e tratados, e eficiências de remoção na Fase 02 $32^{\circ} \mathrm{C}$ e $24 X$ (Continuação).

\begin{tabular}{|c|c|c|c|c|c|c|c|c|}
\hline \multirow{2}{*}{ Batelada } & \multirow{2}{*}{ Amostra } & \multirow{2}{*}{ Unidade } & \multicolumn{5}{|c|}{ Parâmetros } & \multirow{2}{*}{ STV/ST } \\
\hline & & & Resíduo & Água & ST & STF & STV & \\
\hline & 16,02 , e 17 & massa $[\mathrm{g}]$ & 406,08 & 329,65 & 76,43 & 5,56 & 70,87 & 0,927 \\
\hline Média & (cru) & fração [\%] & $(100 \%)$ & 81,18 & 18,82 & 1,37 & 17,45 & \\
\hline \multirow[t]{3}{*}{ Fase 2} & $\begin{array}{c}16,02, \mathrm{e} \\
17\end{array}$ & massa $[\mathrm{g}]$ & 111,61 & 91,92 & 19,86 & 4,27 & 15,59 & 0,783 \\
\hline & (dig.) & fração [\%] & $(100 \%)$ & 82,23 & 17,99 & 3,83 & 14,16 & \\
\hline & Redução & {$[\%]$} & 72,52 & 72,12 & 74,02 & 23,22 & 78,00 & 15,58 \\
\hline
\end{tabular}

Tabela 33 - Caracterização dos resíduos crus e tratados, e eficiências de remoção na Fase 03 $25^{\circ} \mathrm{C}$ e $24 \mathrm{X}$.

\begin{tabular}{|c|c|c|c|c|c|c|c|c|}
\hline \multirow{2}{*}{ Batelada } & \multirow{2}{*}{ Amostra } & \multirow{2}{*}{ Unidade } & \multicolumn{5}{|c|}{ Parâmetros } & \multirow{2}{*}{ STV/ST } \\
\hline & & & Resíduo & Água & ST & STF & STV & \\
\hline \multirow{5}{*}{11} & 10 (cru) & massa [g] & 409,40 & 332,97 & 76,43 & 5,56 & 70,87 & 0,927 \\
\hline & & fração [\%] & $(100 \%)$ & 81,33 & 18,67 & 1,36 & 17,31 & \\
\hline & 10 (dig.) & massa $[\mathrm{g}]$ & 133,91 & 110,04 & 20,51 & 5,71 & 14,80 & 0,721 \\
\hline & & fração [\%] & $(100 \%)$ & 82,18 & 15,32 & 4,27 & 11,05 & \\
\hline & Redução & [\%] & 67,29 & 66,95 & 73,16 & $-2,80$ & 79,12 & 22,20 \\
\hline \multirow{5}{*}{12} & 06 (cru) & massa [g] & 401,10 & 324,67 & 76,43 & 5,56 & 70,87 & 0,927 \\
\hline & & fração [\%] & $(100 \%)$ & 80,94 & 19,06 & 1,39 & 17,67 & \\
\hline & 06 (dig.) & massa $[\mathrm{g}]$ & 109,14 & 88,07 & 21,22 & 5,75 & 15,47 & 0,729 \\
\hline & & fração [\%] & $(100 \%)$ & 80,69 & 19,44 & 5,27 & 14,17 & \\
\hline & Redução & [\%] & 72,79 & 72,88 & 72,24 & $-3,47$ & 78,17 & 21,39 \\
\hline \multirow{5}{*}{14} & 08 (cru) & massa $[\mathrm{g}]$ & 376,40 & 299,97 & 76,43 & 5,56 & 70,87 & 0,927 \\
\hline & & fração [\%] & $(100 \%)$ & 79,69 & 20,31 & 1,48 & 18,83 & \\
\hline & 08 (dig.) & massa [g] & 131,26 & 109,38 & 18,68 & 3,71 & 14,97 & 0,802 \\
\hline & & fração [\%] & $(100 \%)$ & 83,33 & 14,23 & 2,82 & 11,41 & \\
\hline & Redução & [\%] & 65,13 & 63,54 & 75,56 & 33,30 & 78,87 & 13,56 \\
\hline \multirow{5}{*}{$\begin{array}{l}\text { Média } \\
\text { Fase } 3\end{array}$} & 10,06 e 08 & massa $[\mathrm{g}]$ & 395,63 & 319,20 & 76,43 & 5,56 & 70,87 & 0,927 \\
\hline & (cru) & fração [\%] & $(100 \%)$ & 80,66 & 19,34 & 1,41 & 17,94 & \\
\hline & 10,06 e 08 & massa [g] & 124,77 & 102,50 & 20,14 & 5,06 & 15,08 & 0,751 \\
\hline & (dig.) & fração [\%] & $(100 \%)$ & 82,07 & 16,33 & 4,12 & 12,21 & \\
\hline & Redução & [\%] & 68,46 & 67,89 & 73,65 & 9,01 & 78,72 & 19,05 \\
\hline
\end{tabular}

As reduções das massas úmidas de resíduos nas Fases de Adaptação, 01, 02 e 03 foram, respectivamente, de 78,9\%; 75,3\%; 72,5\% e $68,5 \%$. Com relação à massa seca (ST), elas foram, respectivamente, de $81,8 \% ; 76,0 \% ; 74,0 \%$ e $73,7 \%$. Referente a matéria orgânica volátil (STV), as reduções de massa foram, respectivamente, de $85,0 \% ; 80,4 \% ; 78,0 \%$ e $78,8 \%$, mostrando que este sistema de reatores, em qualquer uma das condições testadas, possui potencial para ser 
utilizado no tratamento da fração orgânica dos resíduos sólidos urbanos. Destarte, embora haja diferenças entre as massas observadas, possivelmente devido a erros analíticos dos métodos, as mesmas não foram significativas em termos operacionais, o que responde a segunda questão.

A relação entre a matéria orgânica e nutrientes no resíduo tratado pode ser obtida por meio de uma análise elementar do resíduo, como apresentado na Tabela 34, onde a relação $\mathrm{C} / \mathrm{N}$ do resíduo não digerido, igual a 17,5 , ficou dentro da faixa de 15 a 23 apresentada por Christensen (2011) para resíduos predominantes de cozinha. Nota-se pouca diferença entre a composição do resíduo antes e após o tratamento, tal como os resultados obtidos por Carneiro (2005) no tratamento da fração orgânica dos resíduos sólidos urbanos, utilizando tempo de reação de 95 dias.

Tabela 34 - Composição elementar dos resíduos.

\begin{tabular}{ccccccc}
\hline Amostra & Unidade & C & H & N & P & C/N \\
\hline Não Digerida & $\%^{*}$ & 46,70 & 6,64 & 2,67 & 0,197 & 17,5 \\
\hline Res. Bat. 01 & $\%^{*}$ & - & - & - & - & - \\
Res. Bat. 02 & $\%^{*}$ & 45,37 & 6,43 & 2,57 & 0,073 & 17,7 \\
Res. Bat. 03 & $\%^{*}$ & - & - & - & - & - \\
Res. Bat. 04 & $\%^{*}$ & 47,39 & 6,37 & 3,14 & 0,122 & 15,1 \\
Res. Bat. 05 & $\%^{*}$ & 44,42 & 6,02 & 2,74 & 0,074 & 16,2 \\
Res. Bat. 06 & $\%^{*}$ & 42,35 & 6,04 & 2,54 & 0,116 & 16,7 \\
Res. Bat. 08 & $\%^{*}$ & 46,76 & 6,11 & 2,47 & 0,093 & 19,0 \\
Res. Bat. 09 & $\%^{*}$ & 47,22 & 6,54 & 3,10 & 0,127 & 15,2 \\
Res. Bat. 11 & $\%^{*}$ & 46,75 & 6,42 & 2,76 & 0,123 & 16,9 \\
Res. Bat. 12 & $\%^{*}$ & 44,24 & 5,74 & 3,16 & 0,113 & 14,0 \\
Res. Bat. 13 & $\%^{*}$ & 43,90 & 5,85 & 2,97 & 0,106 & 14,8 \\
Res. Bat. 14 & $\%^{*}$ & 50,88 & 6,98 & 2,87 & 0,085 & 17,7 \\
\hline Média & $\%^{*}$ & $\mathbf{4 5 , 9 3}$ & $\mathbf{6 , 2 5}$ & $\mathbf{2 , 8 3}$ & $\mathbf{0 , 1 0 3}$ & $\mathbf{1 6 , 3}$ \\
\hline
\end{tabular}

* \% em relação à massa de $\mathrm{ST}$, exceto $\mathrm{C} / \mathrm{N}$.

Tomando-se como referência a massa de fósforo, na Tabela 35, são mostradas as proporções entre o mesmo, o carbono, o hidrogênio e o nitrogênio. 
Tabela 35 - Relação C:H:N:P dos resíduos.

\begin{tabular}{cccccccc}
\hline Amostra & C & $:$ & H & $:$ & N & $:$ & P \\
\hline Não Digerida & 237 & $:$ & 33,7 & $:$ & 13,5 & $:$ & 1 \\
\hline Res. Bat. 01 & - & & - & & - & & - \\
Res. Bat. 02 & 620 & $:$ & 87,9 & $:$ & 35,1 & $:$ & 1 \\
Res. Bat. 03 & - & $:$ & - & $:$ & - & $:$ & - \\
Res. Bat. 04 & 387 & $:$ & 52,0 & $:$ & 25,7 & $:$ & 1 \\
Res. Bat. 05 & 596 & $:$ & 80,8 & $:$ & 36,7 & $:$ & 1 \\
Res. Bat. 06 & 366 & $:$ & 52,1 & $:$ & 21,9 & $:$ & 1 \\
Res. Bat. 08 & 501 & $:$ & 65,5 & $:$ & 26,4 & $:$ & 1 \\
Res. Bat. 09 & 372 & $:$ & 51,5 & $:$ & 24,4 & $:$ & 1 \\
Res. Bat. 11 & 381 & $:$ & 52,3 & $:$ & 22,5 & $:$ & 1 \\
Res. Bat. 12 & 392 & $:$ & 50,8 & $:$ & 28,0 & $:$ & 1 \\
Res. Bat. 13 & 415 & $:$ & 55,3 & $:$ & 28,1 & $:$ & 1 \\
Res. Bat. 14 & 601 & $:$ & 82,4 & $:$ & 33,9 & $:$ & 1 \\
\hline Média Bateladas & $\mathbf{4 6 3}$ & $:$ & $\mathbf{6 3 , 1}$ & $:$ & $\mathbf{2 8 , 3}$ & $:$ & $\mathbf{1}$ \\
\hline
\end{tabular}

Como os metais tendem a se concentrarem na matéria orgânica devido aos processos de adsorção, bem como no solo, quando utilizados na agricultura, foram avaliadas as concentrações dos mesmos no resíduo digerido de cada batelada, conforme ilustra a Tabela 36.

Ao se observar os limites estabelecidos pela Resolução CONAMA 375/06 alterada pelo CONAMA 380/06 e os estabelecidos pela Instrução Normativa № 17 - MAPA (2014), verifica-se que dentre os parâmetros analisados, considerando-se os valores médios, somente o níquel não atendeu ao limite estabelecido pelo Anexo VI da Instrução Normativa. Todavia, salienta-se que há uma grande discrepância entre os valores estabelecidos pelo CONAMA e pelo MAPA, bem como há uma proximidade entre os teores de metais obtidos no resíduo não digerido domiciliar cuidadosamente selecionado na fonte e os limites estabelecidos pelo MAPA (2014). Consequentemente, é praticamente inviável o atendimento desses limites em uma coleta seletiva em grande escala, o que possivelmente inviabilizará o uso do resíduo digerido na agricultura. Se além da biodigestão, o resíduo tratado passar posteriormente por um processo de compostagem, visando a melhoria de suas características quanto a estabilização, sanidade e nutrientes, esses metais ainda estariam mais concentrados no composto final. 
Tabela 36 - Concentrações de metais dos resíduos tradados e não digerido [mg/kg].

\begin{tabular}{|c|c|c|c|c|c|c|c|c|c|}
\hline Amostra & $\mathrm{Cr}$ & $\mathrm{Cu}$ & $\mathrm{Pb}$ & $\mathbf{N i}$ & $\mathrm{Zn}$ & Mo & Se & $\mathrm{Na}$ & K \\
\hline Não Digerida & 9,5 & 21,5 & 44,0 & 25,3 & 39,2 & $<L D$ & 59,5 & 7.650 & 15.300 \\
\hline Res. Bat. 01 & - & - & - & - & - & - & - & - & - \\
\hline Res. Bat. 02 & 30,9 & 29,4 & 39,0 & 30,8 & 46,3 & $<L D$ & 29,0 & 18.700 & 9.000 \\
\hline Res. Bat. 03 & - & - & - & - & - & - & - & - & - \\
\hline Res. Bat. 04 & 20,3 & 27,6 & 65,0 & 32,8 & 37,1 & $<L D$ & 48,0 & 18.500 & 9.300 \\
\hline Res. Bat. 05 & 23,7 & 29,4 & 51,0 & 31,7 & 43,7 & $<$ LD & 57,0 & 16.300 & 8.600 \\
\hline Res. Bat. 06 & 22,7 & 33,8 & 34,0 & 33,2 & 51,7 & $<L D$ & 50,0 & 18.700 & 9.900 \\
\hline Res. Bat. 08 & 18,0 & 28,9 & 31,0 & 30,5 & 51,7 & $<$ LD & 70,0 & 16.200 & 9.100 \\
\hline Res. Bat. 09 & 18,2 & 33,7 & 42,0 & 34,1 & 63,2 & $<L D$ & 15,0 & 15.800 & 9.100 \\
\hline Res. Bat. 11 & 14,5 & 27,1 & 42,0 & 31,8 & 37,0 & $<\mathrm{LD}$ & 46,0 & 14.500 & 9.000 \\
\hline Res. Bat. 12 & 21,6 & 38,9 & 49,0 & 40,7 & 112,2 & $<L D$ & 86,0 & 16.100 & 9.500 \\
\hline Res. Bat. 13 & 21,5 & 34,0 & 42,0 & 37,5 & 62,6 & $<$ LD & 75,0 & 16.000 & 10.000 \\
\hline Res. Bat. 14 & 20,8 & 95,0 & 47,0 & 54,3 & 41,4 & $<L D$ & 75,0 & 15.500 & 10.000 \\
\hline Média Bateladas & 21,2 & 37,8 & 44,2 & 35,7 & 54,7 & $<$ LD & 55,1 & 16.630 & 9.350 \\
\hline Desvio Padrão & 4,3 & 20,4 & 9,6 & 7,3 & 22,2 & $<$ LD & 22,2 & 1.474 & 484 \\
\hline Limite Detecção & 0,005 & 0,003 & 0,01 & 0,008 & 0,002 & 0,001 & 0,001 & 0,1 & 0,1 \\
\hline $\begin{array}{c}\text { Limite para disp. } \\
\text { no solo (CONAMA } \\
375 / 06)^{\star}\end{array}$ & 1000 & 1500 & 300 & 420 & 2800 & 50 & 100 & - & - \\
\hline $\begin{array}{l}\text { Limite em resíduos } \\
\text { de biodigestor (IN } \\
\text { 17-MAPA, 2014)* }\end{array}$ & 70 & 70 & 45 & 25 & 200 & - & 80 & - & - \\
\hline
\end{tabular}

OBS: LD = Limite de detecção. * A norma também considera os elementos: Arsênio, Bário, Cádmio, e Mercúrio, que não foram analisados por problemas no equipamento.

Visando responder a última a questão referente aos resíduos, foram realizados exames de microscopia ótica e de MEV em amostras retiradas dos resíduos digeridos.

O resíduo inserido no digestor foi previamente congelado em freezer, contribuindo para inativação dos micro-organismos existentes no mesmo. Todavia, a solubilização e a acidificação ocorreram no sistema, e desde o primeiro dia a produção de metano foi verificada, indicando uma provável rápida colonização do resíduo por organismos existentes no filtro anaeróbio, o que pôde ser comprovado pela presença de morfologias de microrganismos hidrolíticos e metanogênicos, tais como: cocos, bacilos, víbrio, methanosaetas, methanobrevibacter e methanosarcina (Figura 48). 
Figura 48 - Imagens de microscopia ótica do resíduo tratado apresentando diversidade de morfologias.

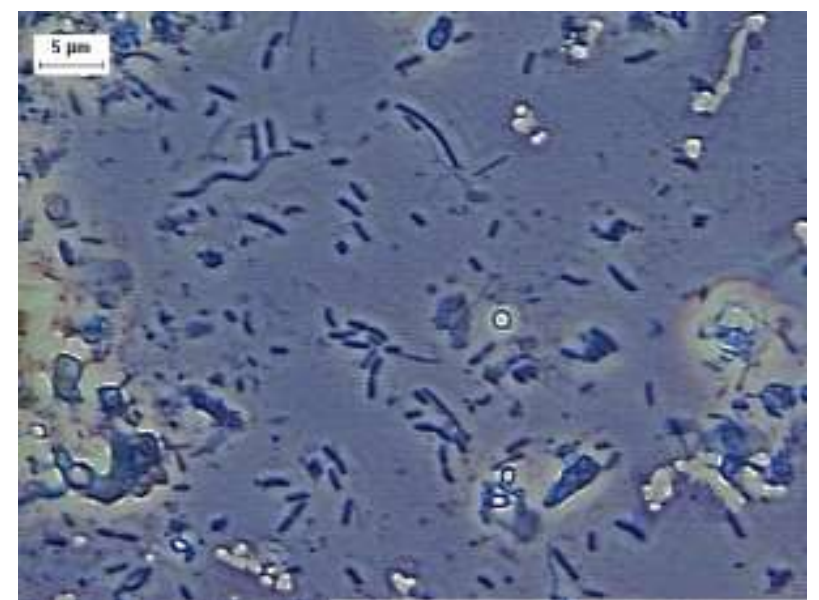

(a) Cocos, bacilos, vibrio e methanosaetas.

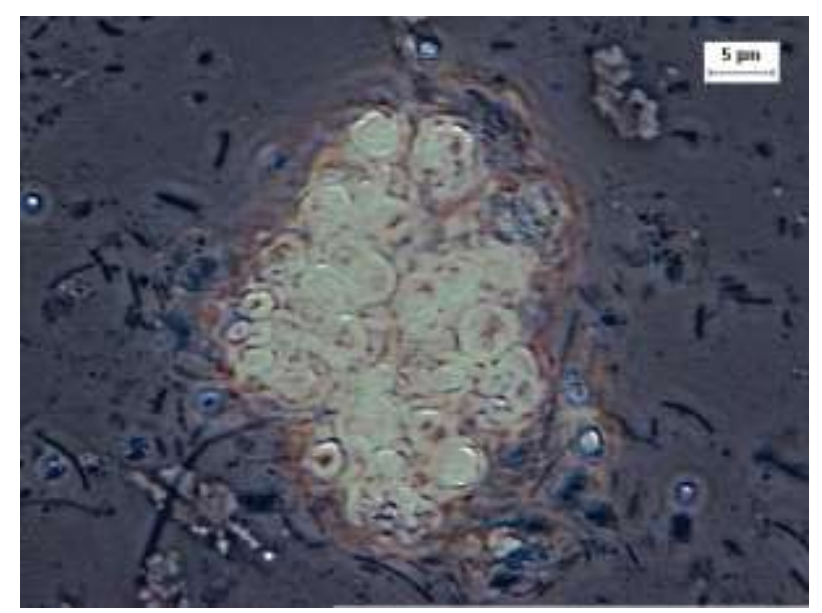

(c) Methanosarcina.

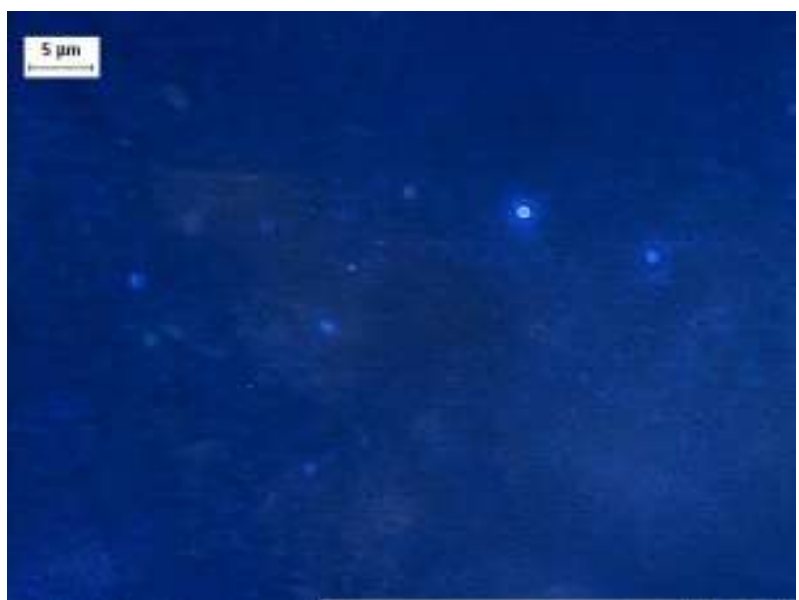

(b) Methanobrevibacter sob fluorescência.

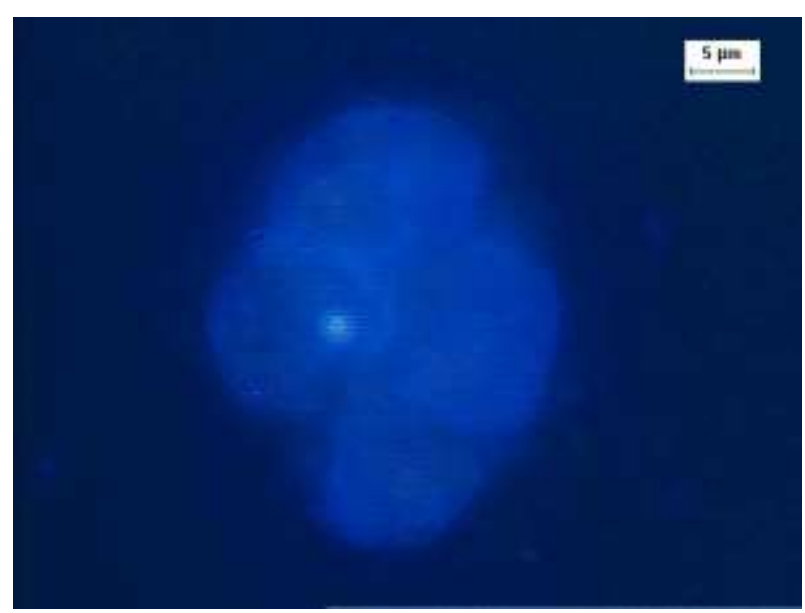

(d) Methanosarcina sob fluorescência.

Pelas imagens de MEV da Figura 49, faz-se possível a diferenciação entre as morfologias hidrolíticas, item (a) e as metanogênicas, itens (b), (c) e (d), devido a ordem de grandeza das dimensões das mesmas. Dessa forma, apesar da separação entre as unidades de tratamento, a recirculação de líquidos permitiu a colonização das metanogênicas nos resíduos do reator hidrolítico. 
Figura 49 - Imagens de MEV do resíduo tratado.

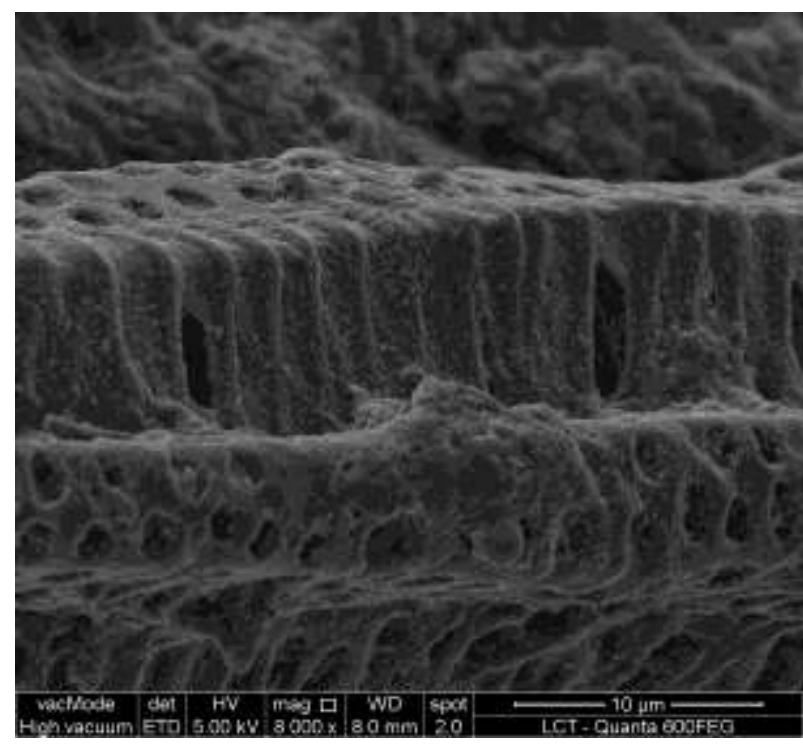

(a) Estrutura vegetal densamente colonizada.

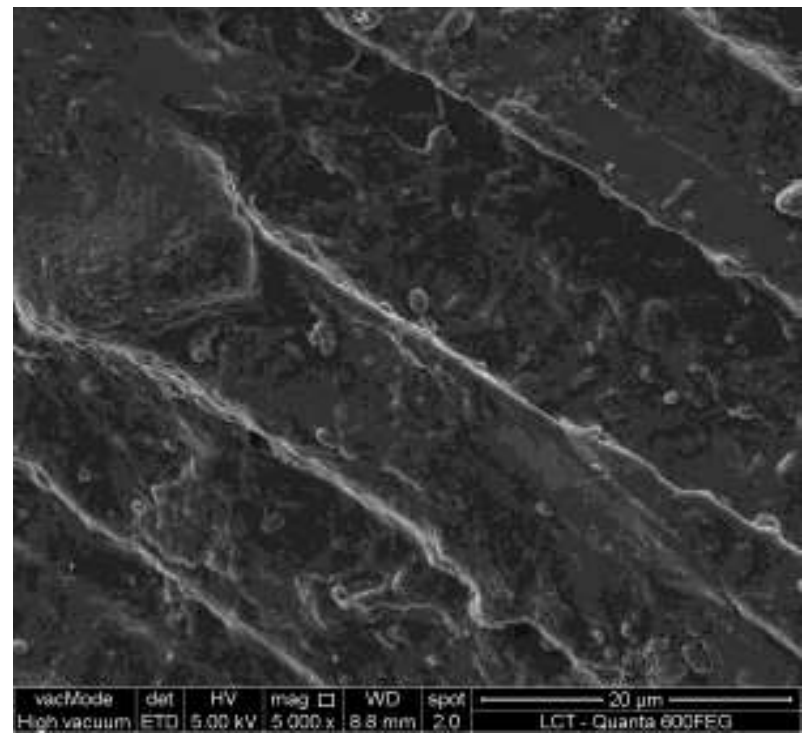

(c) Superfície vegetal densamente povoada.

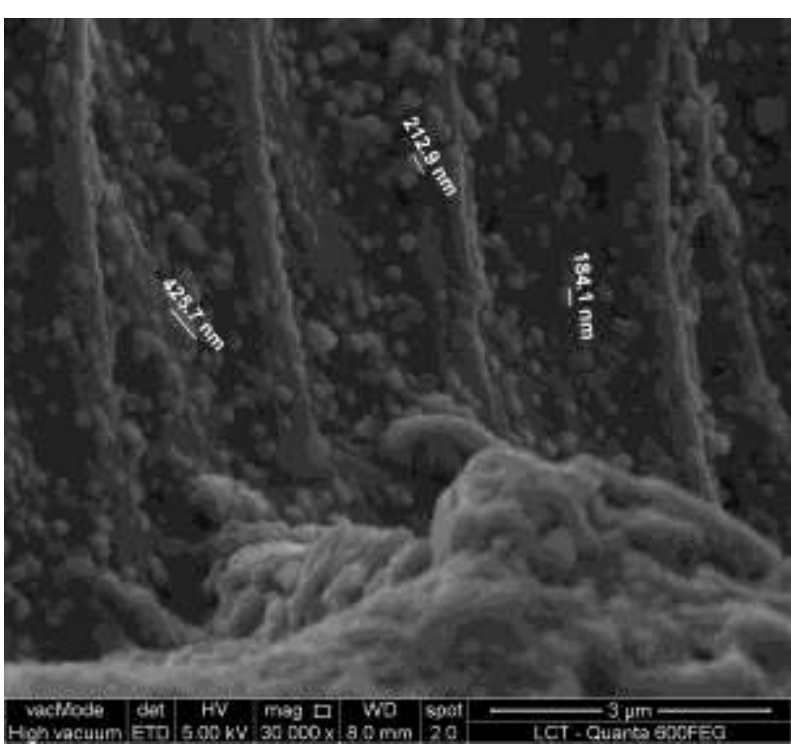

(b) Morfologias semelhantes cocos e bacilos hidrolítico.

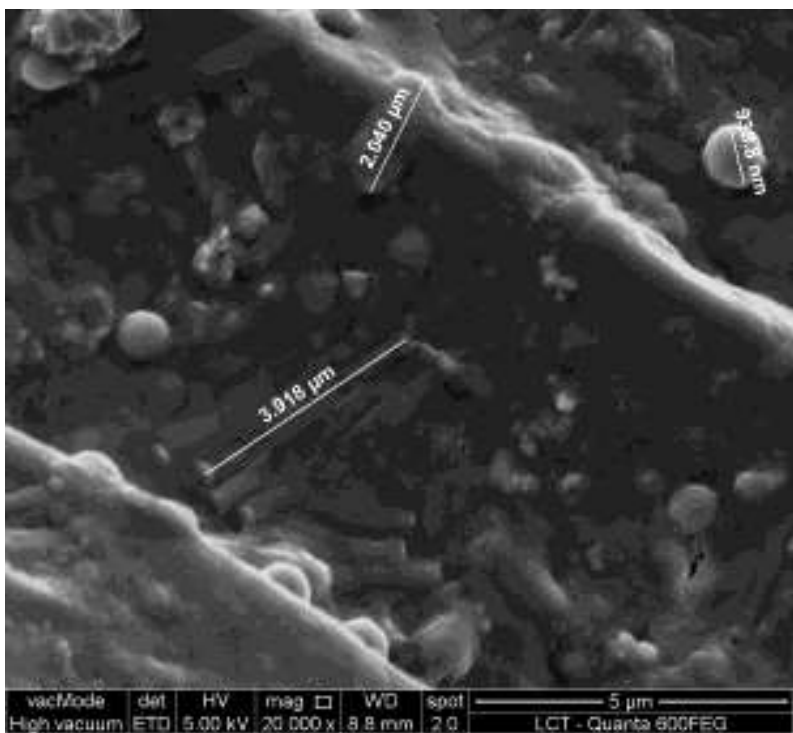

(d) Morfologias semelhantes à cocos, bacilos e methanosaetas.

Segundo o PROBIOGÁS (2013), qualquer tentativa de isolar a hidrólise e a acidogênese da metanogênese por meio de sistema de duas fases tem êxito limitado, pois ocorre a formação parcial de metano no reator hidrolítico, que necessita ser consumido ou tratado a fim de evitar riscos à segurança e impactos negativos sobre o meio ambiente. Desta forma, ressalta-se que seria muito importante, em trabalhos futuros, a quantificação das morfologias metanogênicas no reator hidrolítico, bem como a determinação do volume de metano gerado neste reator. 


\subsection{Biomassa Anaeróbia aderida ao meio suporte}

A respeito da biomassa aderida ao meio suporte foram levantadas as seguintes questões: 1) Qual foi a quantidade de biomassa produzida durante o experimento realizado? 2) Houve acúmulo de metais na biomassa ao longo do tempo? 3) Qual foi a diversidade microbiana no lodo de inóculo e no lodo aderido à espuma?

Ao se observar as concentrações de SSV no líquido de recirculação (Figura 50), nota-se um aumento destes nos mesmos períodos de aumento de COT ou do AVT, o que indica o crescimento dos micro-organismos no sistema.

Os resultados das duas amostragens realizadas na biomassa, antes e após o experimento, são apresentados na Tabela 37. Verifica-se que a massa média dos STV aderido ao meio suporte cresceu 19,39\% entre uma amostragem e outra.

Tabela 37 - Caracterização da biomassa aderida ao meio suporte.

\begin{tabular}{|c|c|c|c|c|c|c|c|c|}
\hline \multirow{2}{*}{ Amostragem } & \multirow{2}{*}{ Amostra* } & $M_{\mathrm{Bob}}{ }^{\star *}$ & $\mathrm{~L}_{\text {Bob }}{ }^{* *}$ & $M_{\text {Esp. }}{ }^{* *}$ & $\mathrm{~V}_{\text {Esp. }}{ }^{* *}$ & $S T^{\star \star}$ & $\mathrm{STF}^{\star \star}$ & STV** \\
\hline & & [mg] & {$[\mathrm{cm}]$} & [mg] & {$\left[\mathrm{cm}^{3}\right]$} & [mg] & [mg] & [mg] \\
\hline \multirow{5}{*}{1} & (a) & 247,11 & 1,28 & 21,71 & 1,15 & 138,10 & 105,10 & 33,00 \\
\hline & (b) & 244,16 & 1,25 & 21,32 & 1,12 & 150,50 & 116,70 & 33,80 \\
\hline & (c) & 258,09 & 1,33 & 21,89 & 1,29 & 141,50 & 109,90 & 31,60 \\
\hline & Média & 249,79 & 1,29 & 21,64 & 1,19 & 143,37 & 110,57 & 32,80 \\
\hline & Des. Pad. & 7,34 & 0,22 & 0,29 & 0,37 & 6,41 & 5,83 & 1,11 \\
\hline \multirow{7}{*}{2} & (a) & 240,10 & 1,25 & 21,30 & 1,10 & 152,40 & 112,40 & 40,00 \\
\hline & (b) & 238,00 & 1,20 & 19,10 & 0,94 & 148,00 & 109,60 & 38,40 \\
\hline & (c) & 240,20 & 1,21 & 20,90 & 1,02 & 133,50 & 94,70 & 38,80 \\
\hline & (d) & 240,30 & 1,26 & 20,70 & 1,01 & 139,20 & 101,80 & 37,40 \\
\hline & (e) & 240,40 & 1,21 & 20,60 & 1,04 & 159,30 & 118,10 & 41,20 \\
\hline & Média & 239,80 & 1,22 & 20,52 & 1,02 & 146,48 & 107,32 & 39,16 \\
\hline & Des. Pad. & 1,01 & 0,12 & 0,84 & 0,19 & 10,29 & 9,18 & 1,47 \\
\hline Dif. Médias & $\%$ & $-4,00$ & $-4,75$ & $-5,18$ & $-13,87$ & $+2,17$ & $-2,94$ & $+19,39$ \\
\hline
\end{tabular}

* Amostra composta por 10 unidades de meio suporte

** Valores médios referentes a cada unidade de meio suporte. 
Figura 50 - Variações das concentrações de Sólidos em Suspensão Voláteis nas diferentes fases do experimento.

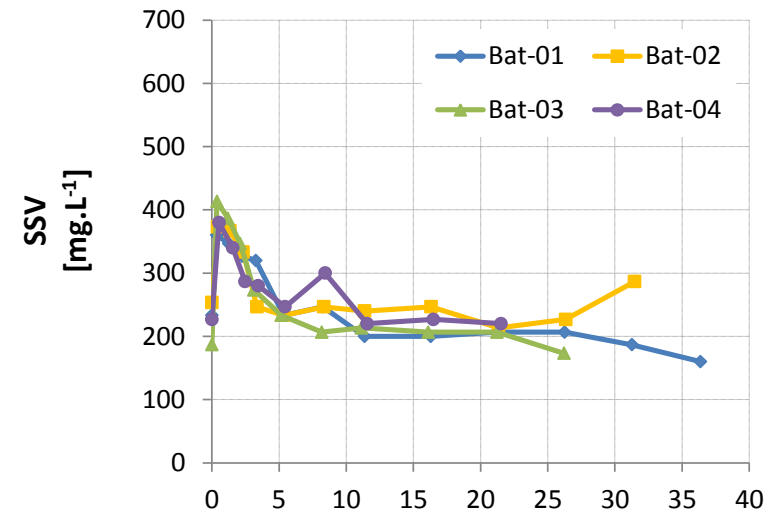

Tempo [dias]

(a) Na Fase de Adaptação.

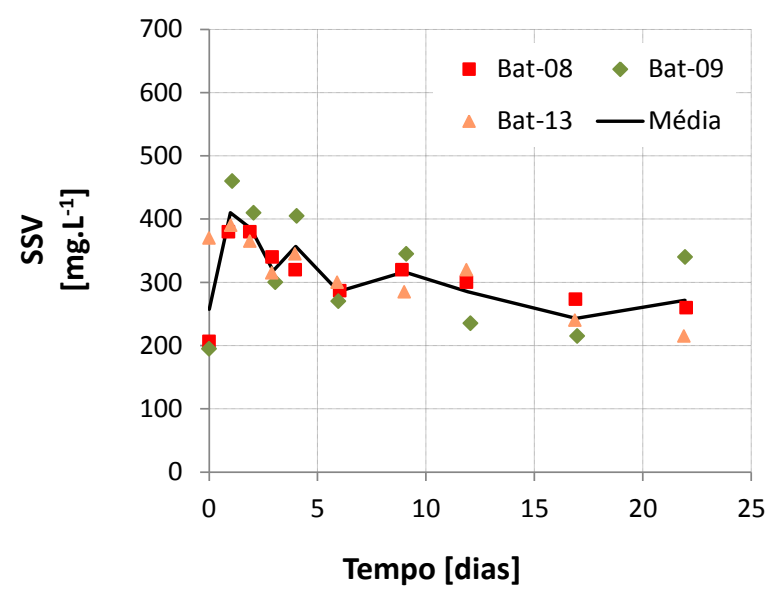

(c) Na Fase 2 a 24 ciclos por dia e $32^{\circ} \mathrm{C}$.

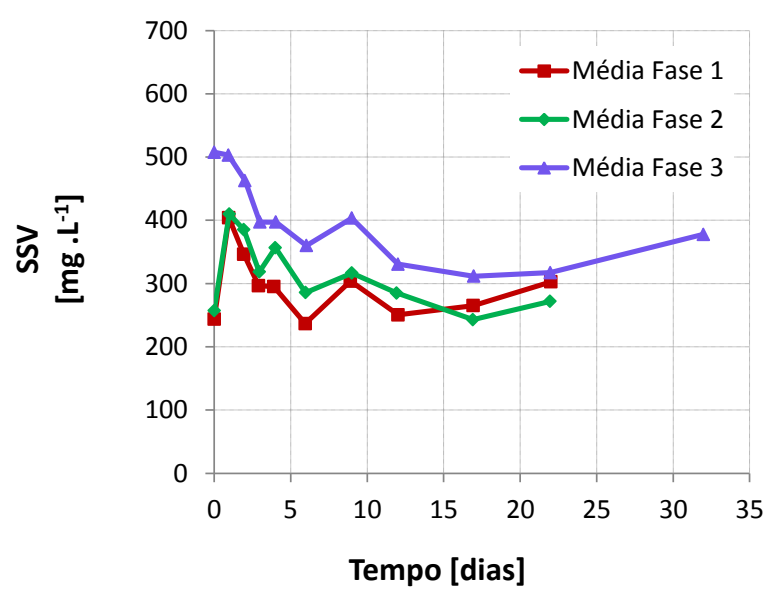

(e) Comparação entre as médias das Fases 1, 2 e 3.

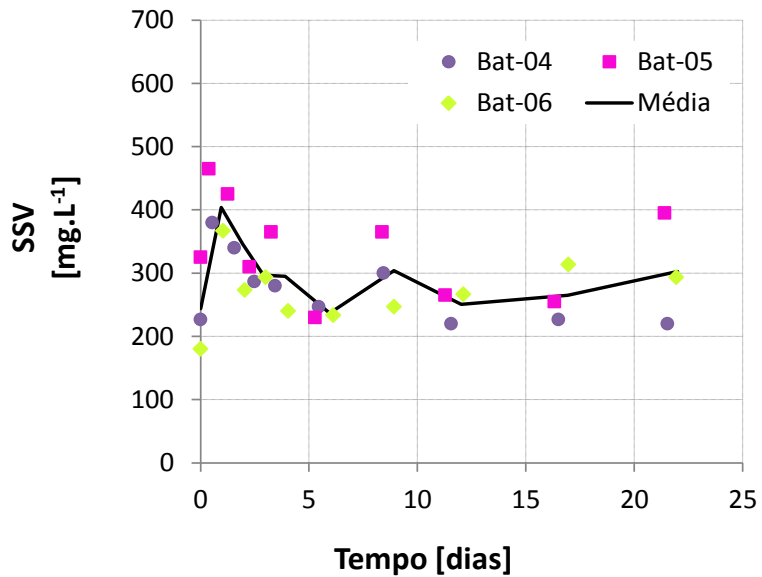

(b) Na Fase 1 a 12 ciclos por dia e $32^{\circ} \mathrm{C}$.

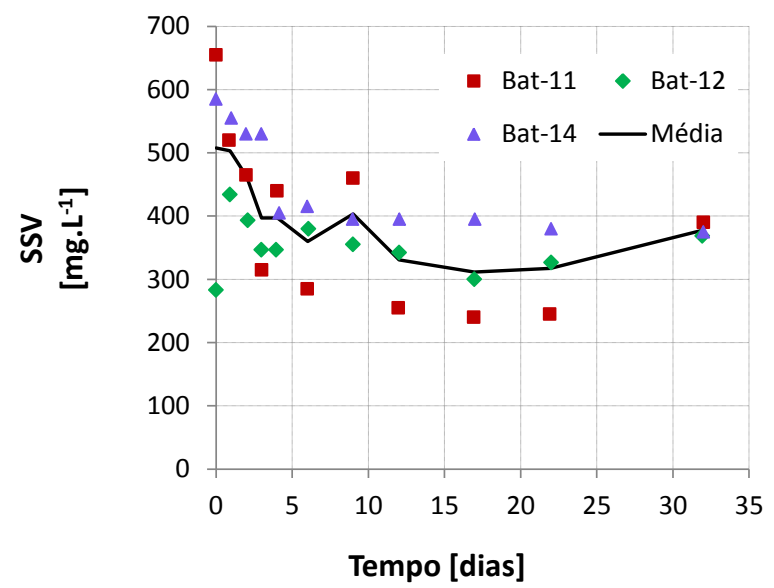

(d) Na Fase 3 a 24 ciclos por dia e $25^{\circ} \mathrm{C}$.

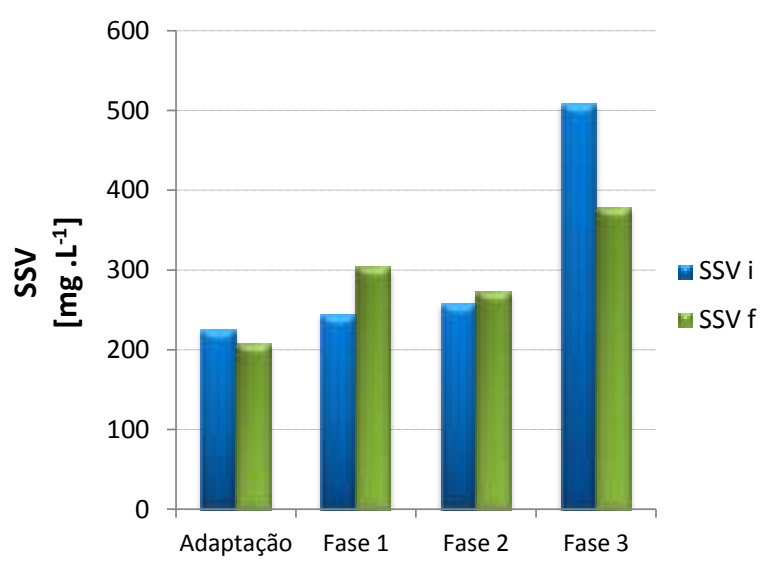

(f) Inicial e final nas quatro fases. 
Com a finalidade de normalizar os resultados obtidos, foi criada a Tabela 38, onde são mostradas algumas relações entre parâmetros da biomassa e meio suporte para as duas amostragens realizadas. Por meio destas relações é possível se verificar mais claramente o crescimento celular, principalmente através das relações com sólidos totais, massa de espuma e massa de meio suporte, respectivamente, STV/ST (+17,04\%), STV/MESP (+25,98\%) e STV/M MS (+24,34\%).

Tabela 38 - Relações entre parâmetros da biomassa e meio suporte.

\begin{tabular}{|c|c|c|c|c|c|c|c|c|}
\hline \multirow{2}{*}{ Amostragem } & \multirow{2}{*}{ Amostra $^{*}$} & STV/ST & $S T / M_{\text {Esp. }}$ & $\mathrm{ST} / \mathrm{M}_{\mathrm{MS}}$ & $\mathrm{ST} / \mathrm{V}_{\text {Esp. }}$ & $\mathrm{STV} / \mathrm{M}_{\text {Esp. }}$ & $\mathrm{STV} / \mathrm{M}_{\mathrm{MS}}$ & STV/V \\
\hline & & - & - & - & {$\left[\mathrm{mg} / \mathrm{cm}^{3}\right]$} & - & - & {$\left[\mathrm{mg} / \mathrm{cm}^{3}\right]$} \\
\hline \multirow{5}{*}{1} & (a) & 0,239 & 6,36 & 0,514 & 119,83 & 1,52 & 0,123 & 28,63 \\
\hline & (b) & 0,225 & 7,06 & 0,567 & 134,11 & 1,59 & 0,127 & 30,12 \\
\hline & (c) & 0,223 & 6,46 & 0,505 & 110,06 & 1,44 & 0,113 & 24,58 \\
\hline & Média & 0,229 & 6,63 & 0,529 & 121,34 & 1,52 & 0,121 & 27,78 \\
\hline & Des. Pad. & 0,009 & 0,38 & 0,033 & 12,10 & 0,07 & 0,007 & 2,87 \\
\hline \multirow{7}{*}{2} & (a) & 0,262 & 7,15 & 0,583 & 138,63 & 1,88 & 0,153 & 36,39 \\
\hline & (b) & 0,259 & 7,75 & 0,576 & 156,89 & 2,01 & 0,149 & 40,71 \\
\hline & (c) & 0,291 & 6,39 & 0,511 & 131,36 & 1,86 & 0,149 & 38,18 \\
\hline & (d) & 0,269 & 6,72 & 0,533 & 137,57 & 1,81 & 0,143 & 36,96 \\
\hline & (e) & 0,259 & 7,73 & 0,610 & 153,16 & 2,00 & 0,158 & 39,61 \\
\hline & Média & 0,268 & 7,15 & 0,563 & 143,52 & 1,91 & 0,150 & 38,37 \\
\hline & Des. Pad. & 0,013 & 0,60 & 0,040 & 10,94 & 0,09 & 0,005 & 1,80 \\
\hline Dif. Médias & $\%$ & $+17,04$ & $+7,87$ & $+6,44$ & $+18,29$ & $+25,98$ & $+24,34$ & $+38,13$ \\
\hline
\end{tabular}

* Amostra composta por 10 unidades de meio suporte

Ao se estimar a quantidade de unidades de meio suporte, chegou-se ao número de 3.595 unidades. A partir deste número foi possível calcular as quantidades inicial e final de biomassa em termos de STV, chegando-se respectivamente a 117,93 g e $140,79 \mathrm{~g}$, ou seja um crescimento de $19,4 \%$.

Uma vez que a concentração média inicial de STV dos resíduos tratados foi de aproximadamente $70,87 \mathrm{~g}$ por batelada, é possível se estabelecer a relação entre STV da biomassa e STV do resíduo no início e no fim do experimento, chegando-se

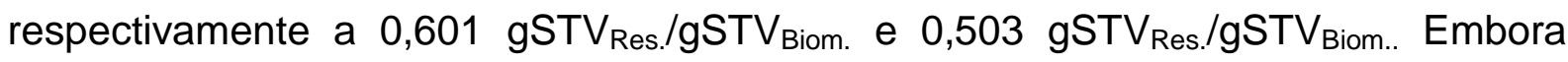
este parâmetro possa ser útil na avaliação da relação Alimento/Microrganismo (A/M), ele dificilmente é relatado na literatura para sistemas tratando resíduos sólidos. Mesmo em sistemas que trabalham com resíduo e biomassa microbiana totalmente 
misturados. (sistema de uma fase) há meios de quantificar os organismos utilizandose técnicas como o q-PCR, e desta forma, obter essa relação A/M.

Conhecendo-se o quanto a biomassa anaeróbia cresceu no período $(22,87 \mathrm{~g})$ e qual foi a quantidade total de STV removida dos resíduos $(859,49 \mathrm{~g})$, é possível se determinar o coeficiente de produção celular ( $\left.\mathrm{Y}_{\mathrm{X} / \mathrm{S}}\right)$ para biomassa anaeróbia, chegando-se ao valor de 0,0266 gSTV $_{\text {Biom. }} / \mathrm{gSTV}_{\text {Res. }}$. De acordo com Nielfa et al. (2015), a fração orgânica dos resíduos sólidos apresenta valores típicos de DQO iguais a $542 \mathrm{~g} / \mathrm{kg}$ e de STV iguais a $394 \mathrm{~g} / \mathrm{kg}$, perfazendo uma relação DQO/STV igual a 1,376 gDQO/gSTV. Dessa forma, convertendo-se os STV do resíduo em

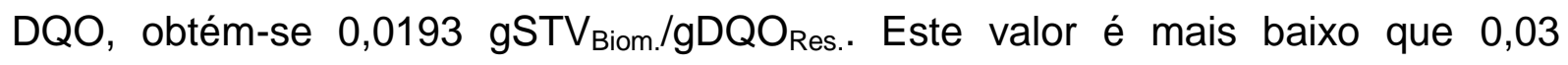
gSSV/gDQO apresentado por Henze and Harremöes ${ }^{10}$ (1983) apud Khanal (2008) para metanogênicas e também mais baixo que a faixa 0,05 a 0,15 mencionada por van Haandel and Lettinga ${ }^{11}$ (1994) apud Khanal (2008) para tratamentos anaeróbios. Uma possível explicação para o baixo valor do $Y_{X / S}$, calculado a partir do crescimento do lodo aderido à espuma, pode ser o crescimento de biomassa também no resíduo, como comprovado através das imagens de microscopia ótica e MEV, respectivamente, na Figura 48 e na Figura 49, que mostram uma elevada colonização do resíduo tratado. Adicionalmente, esta diferença também pode estar relacionada ao fato dos valores apresentados pela literatura se referirem ao tratamento anaeróbio de águas residuárias, onde os compostos já estão solúveis, aumentando-se assim, as taxas de síntese celular.

Com o objetivo de se avaliar o acúmulo de metais na biomassa anaeróbia foram realizadas duas amostragens, sendo a primeira antes do início do experimento e a segunda depois do final do experimento (Tabela 39).

\footnotetext{
${ }^{10} \mathrm{HENZE}, \mathrm{M}$. E HARREMÖES, P. Anaerobic treatment of waste water in fixed film reactors - a literature review. Water Sci. Technol. 15:1-101, 1983.

${ }_{11}$ VAN HAANDEL, A. C. E LETTINGA, G. Anaerobic sewage treatment: A practical guide for regions with a hot climate. John Wiley \& Sons, Chichester, England, 1994.
} 
Tabela 39 - Teores de metais na biomassa anaeróbia antes e depois da operação do sistema, com base no teor de ST [mg/kgST].

\begin{tabular}{cccccccccc}
\hline Amostra & $\mathbf{C r}$ & $\mathbf{C u}$ & $\mathbf{P b}$ & $\mathbf{N i}$ & $\mathbf{Z n}$ & $\mathbf{M o}$ & $\mathrm{Se}$ & $\mathbf{N a}$ & $\mathbf{K}$ \\
\hline Antes & 103,8 & 287,2 & 109,0 & 141,0 & $1.484,0$ & $<$ LD & 48,0 & 26.800 & 14.100 \\
Depois & 160,8 & 263,9 & 199,7 & 169,8 & $1.019,7$ & $<$ LD & 78,8 & 12.300 & 9.200 \\
\hline Diferença [\%] & $\mathbf{+ 5 4 , 9}$ & $\mathbf{- 8 , 1}$ & $\mathbf{+ 8 3 , 2}$ & $\mathbf{+ 2 0 , 4}$ & $\mathbf{- 3 1 , 3}$ & - & $\mathbf{+ 6 4 , 2}$ & $\mathbf{- 5 4 , 1}$ & $\mathbf{- 3 4 , 8}$ \\
\hline
\end{tabular}

OBS: LD = Limite de detecção.

Como os metais tendem a adsorver na matéria orgânica e o lodo de inóculo possuía uma fração inorgânica proveniente da argila da lagoa de lixiviados, uma forma de melhorar a análise da quantidade de metais adsorvida à biomassa seria relacionar os teores de metais aos de STV da biomassa como apresentado na Tabela 40.

Tabela 40 - Teores de metais na biomassa anaeróbia antes e depois da operação do sistema, com base no teor de STV [mg/kgSTV].

\begin{tabular}{cccccccccc}
\hline Amostra & $\mathbf{C r}$ & $\mathbf{C u}$ & $\mathbf{P b}$ & $\mathbf{N i}$ & $\mathbf{Z n}$ & Mo & Se & Na & $\mathbf{K}$ \\
\hline Antes & 453,3 & $1.254,1$ & 476,0 & 615,7 & $6.480,3$ & $<$ LD & 209,6 & 117.031 & 61.572 \\
Depois & 600,0 & 984,7 & 745,1 & 633,6 & $3.804,9$ & $<$ LD & 294,0 & 45.896 & 34.328 \\
\hline Diferença [\%] & $\mathbf{+ 3 2 , 4}$ & $\mathbf{- 2 1 , 5}$ & $\mathbf{+ 5 6 , 5}$ & $\mathbf{+ 2 , 9}$ & $\mathbf{- 4 1 , 3}$ & - & $\mathbf{+ 4 0 , 3}$ & $\mathbf{- 6 0 , 8}$ & $\mathbf{- 4 4 , 2}$ \\
\hline
\end{tabular}

OBS: LD = Limite de detecção.

Avaliando-se os teores de metais na biomassa, constata-se que houve um aumento do cromo, chumbo, níquel e selênio, mas por outro lado, ocorreu redução dos teores de cobre, zinco, sódio e potássio. Deste modo, conclui-se que houve acúmulo de alguns metais na biomassa.

Para se avaliar a diversidade microbiológica no lodo de inóculo e no lodo aderido à espuma foram realizadas microscopia ótica e de varredura. Na Figura 51 e Figura 52 são identificadas morfologias hidrolíticas, tais como cocos e bacilos, e metanogênicas, como methanosaetas, bacilos, cocos e methanobrevibacter, que se destacam sob fluorescência. 
Figura 51 - Morfologias identificadas nas imagens de microscopia ótica do lodo de inóculo.

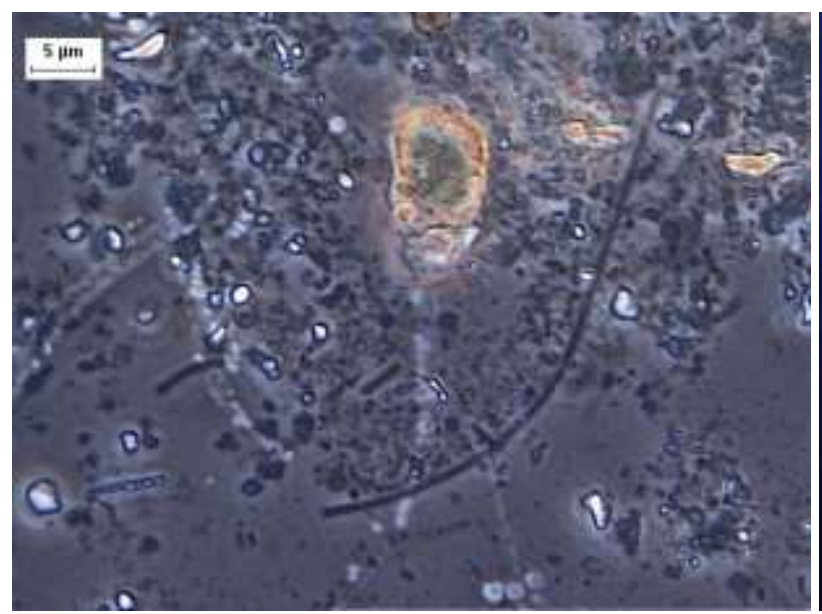

(a) Methanosaetas, bacilos e cocos.

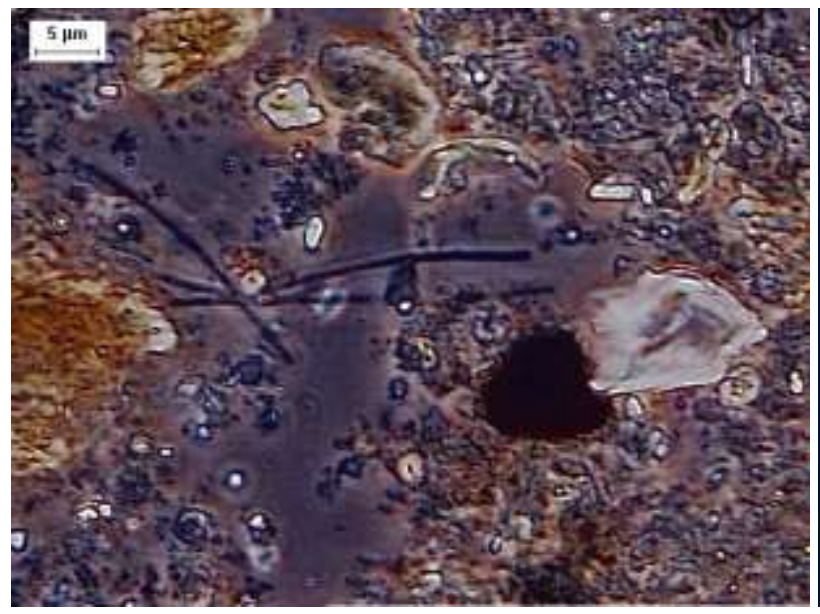

(c) Methanosaetas.

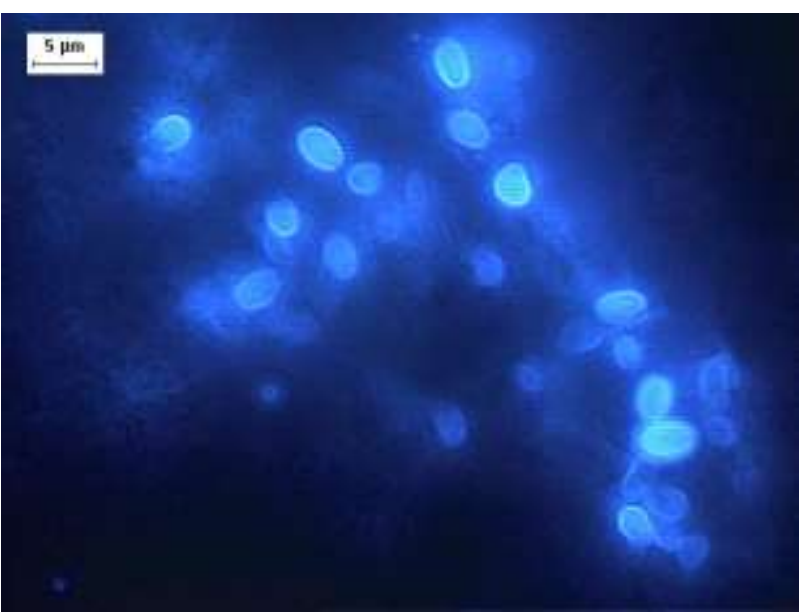

(b) Bacilos sob fluorescência.

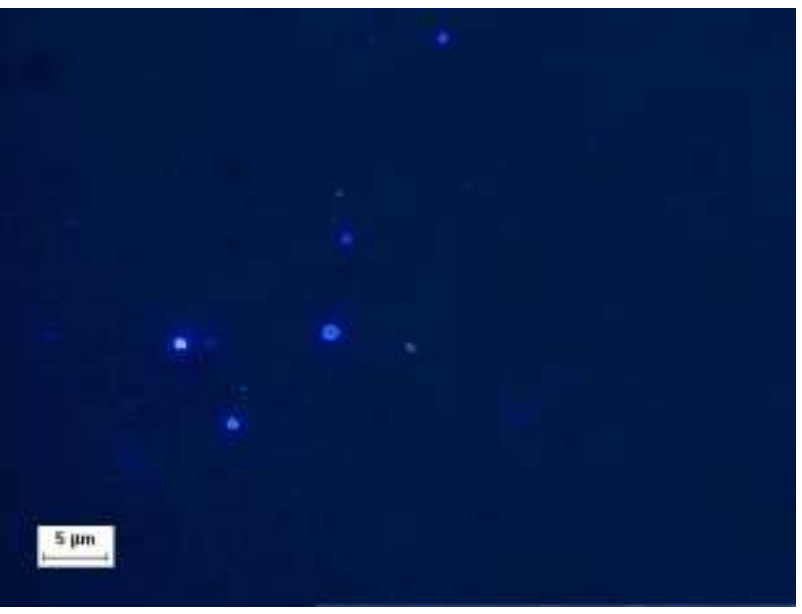

(d) Methanobrevibacter sob fluorescência.

Figura 52 - Imagens de microscopia eletrônica de varredura do lodo de inóculo.

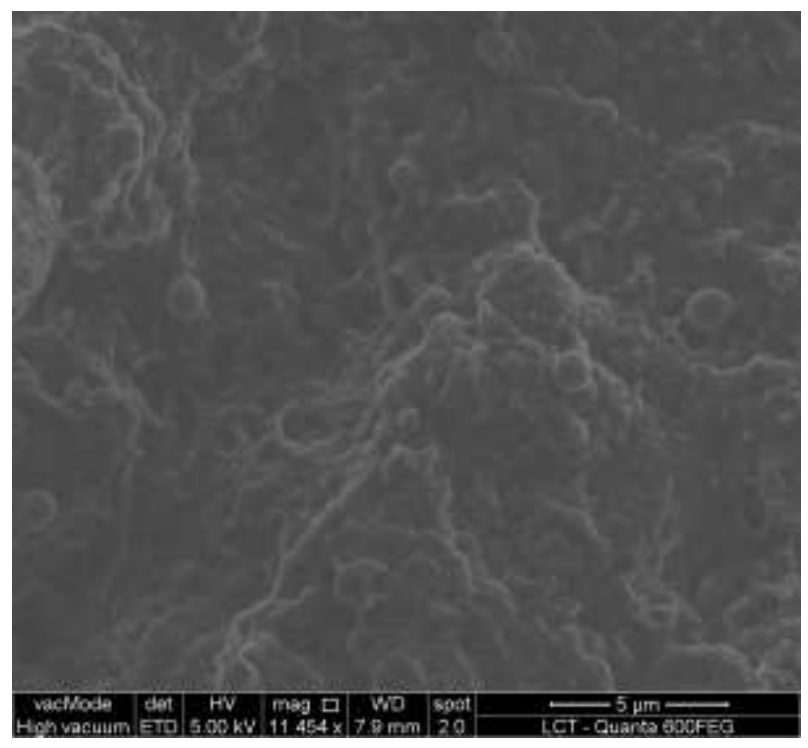

(a) Morfologias semelhantes a cocos.

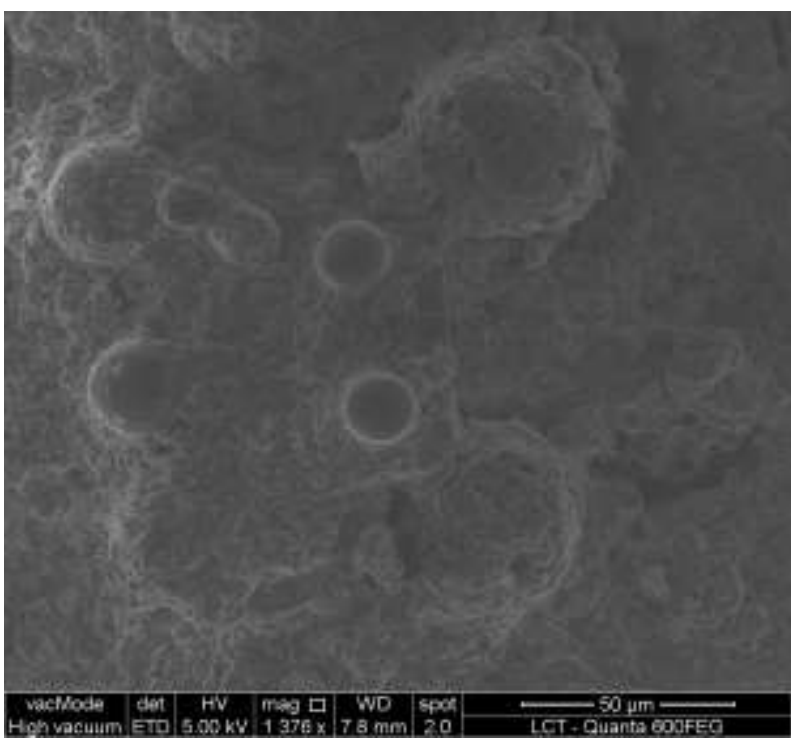

(b) Estruturas granulares. 
Para o lodo extraído da espuma ao final do experimento (Figura 54 e Figura 55) foram identificadas morfologias hidrolíticas, tais como cocos, diplococos, víbrios e bacilos, e metanogênicas, como methanosaetas, bacilos e cocos.

Figura 53 - Morfologias identificadas nas imagens de microscopia ótica do lodo extraído da espuma ao final do experimento.

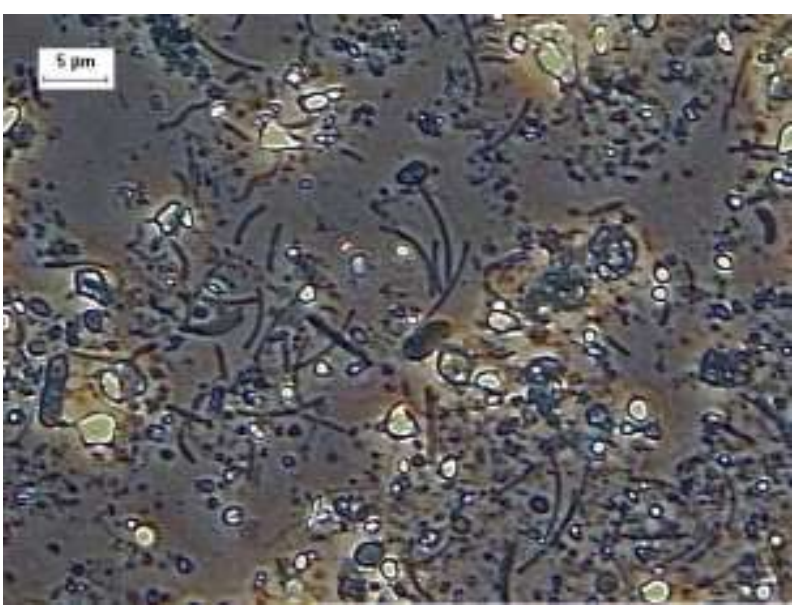

(a) Bacilos, cocos, methanosaetas e víbrios.

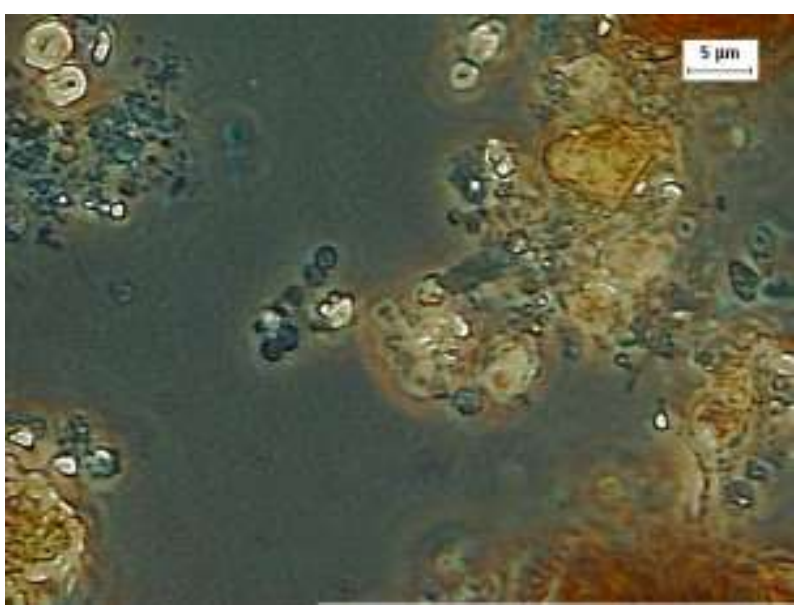

(b) Diplococos.

Figura 54 - Morfologias identificadas nas imagens de microscopia eletrônica de varredura do lodo extraído da espuma ao final do experimento.

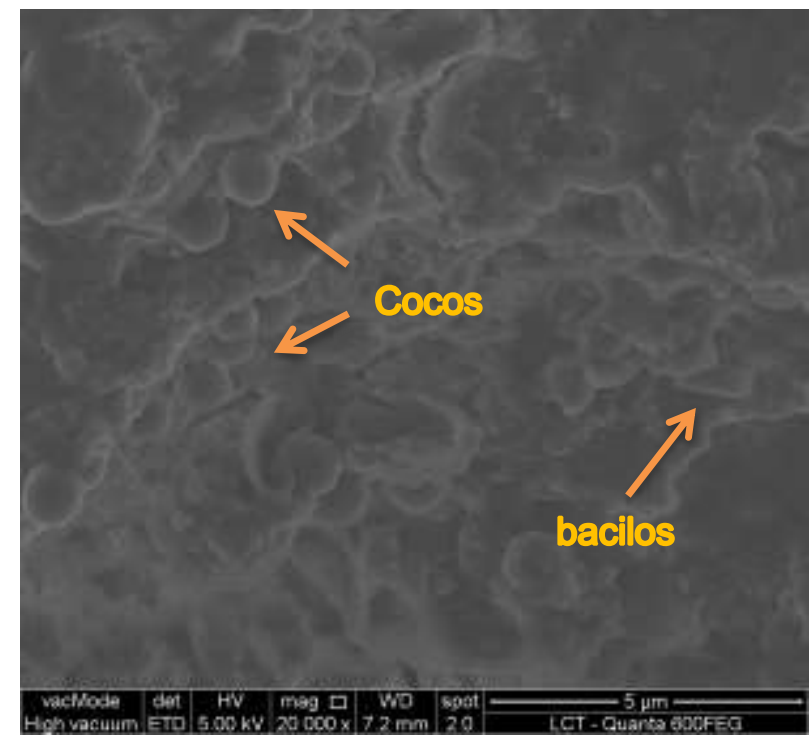

(a) Cocos e bacilos.

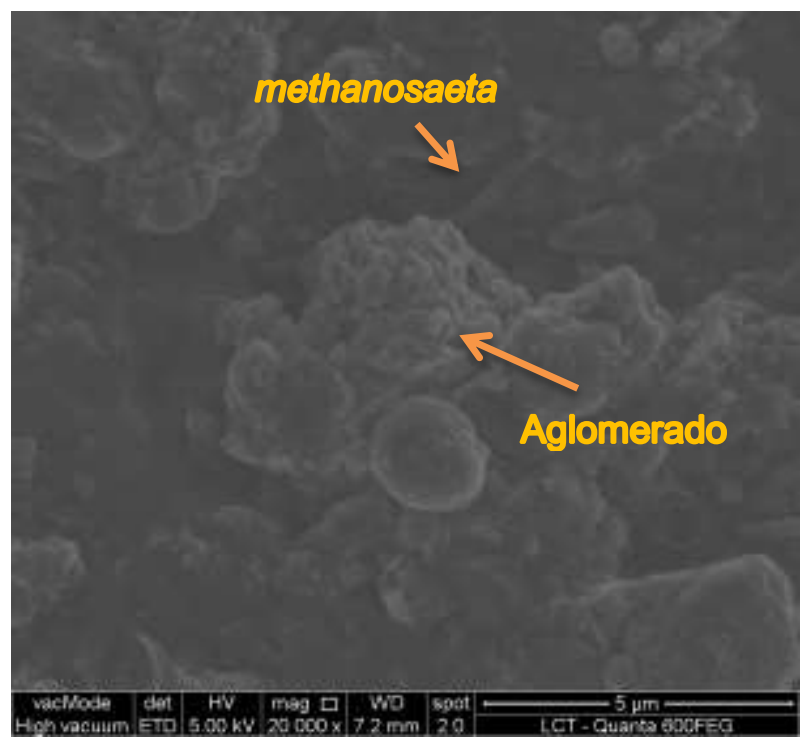

(b) Methanosaeta e aglomerado ao centro.

A Figura 55 ilustra a estrutura de poros abertos da espuma, bem como o lodo aderido a ela; a Figura 56 mostra tanto a superfície externa quanto a interna da espuma densamente povoada por Cocos, bacilos e methanosaetas. 
Figura 55 - Imagem de microscopia eletrônica de varredura da espuma colonizada.

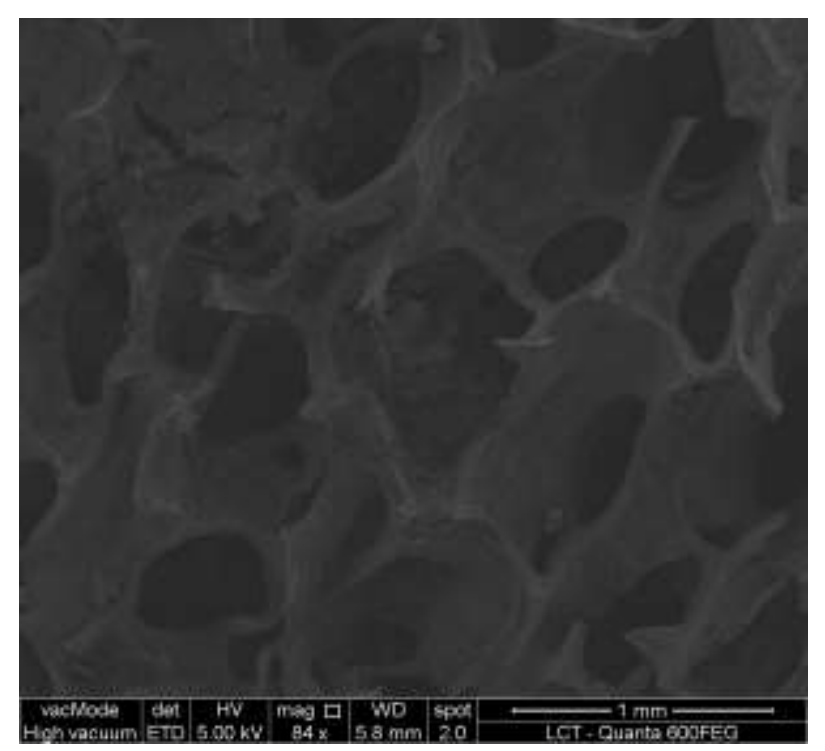

Figura 56 - Imagens de microscopia eletrônica de varredura do lodo aderido à espuma ao final do experimento.

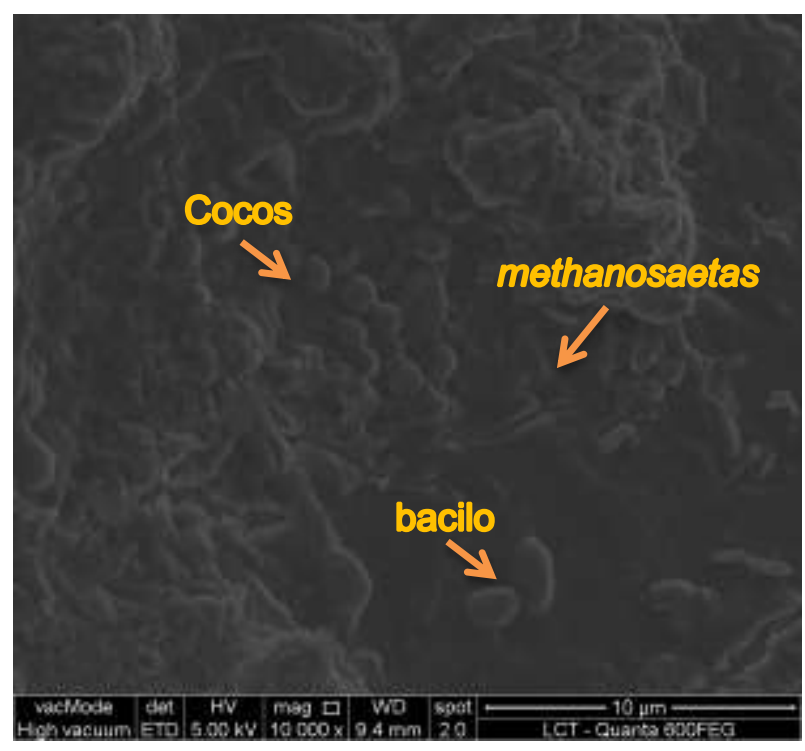

(a) Cocos, bacilos e methanosaetas na superfície externa.

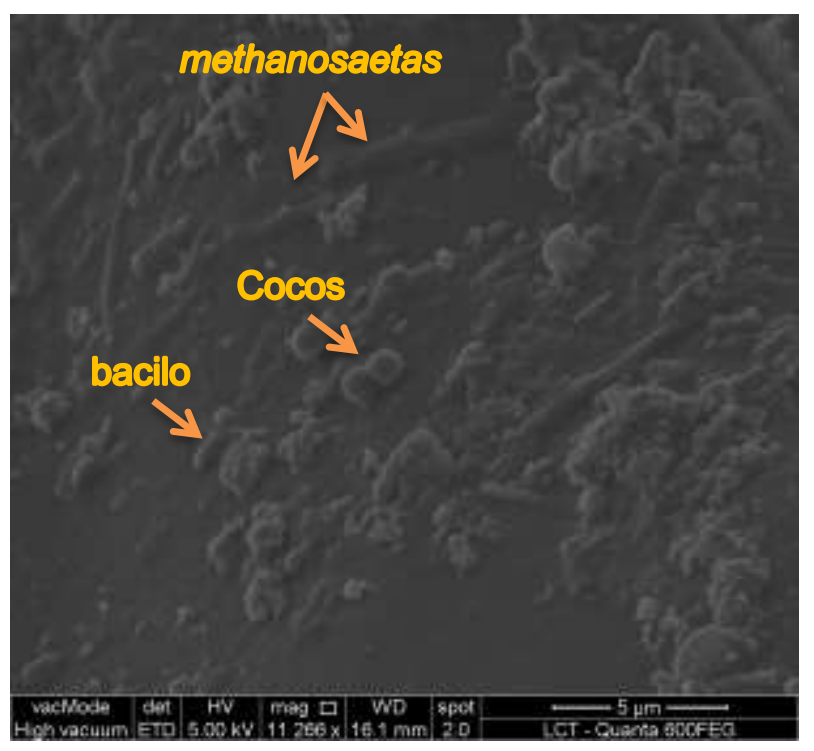

(b) Cocos, bacilos e methanosaetas na superfície interna. 


\section{CONCLUSÕES}

Considerando-se uma pré-adaptação com etanol e uma batelada teste inicial, foram necessárias 5 bateladas com resíduos para otimização do tempo de reação, em 22 dias para operação a $32{ }^{\circ} \mathrm{C}$ e 32 dias para operação a $25^{\circ} \mathrm{C}$.

Ao se reduzir a temperatura operacional de $32{ }^{\circ} \mathrm{C}$ para $25^{\circ} \mathrm{C}$, mesmo aumentandose o tempo de reação para 32 dias, houve uma redução média na produção de biogás de 24,8\%. Ao se considerar um tempo comum de reação, de 22 dias, essa diferença passou a ser de 32,4\%, ou seja, houve uma redução de aproximadamente um terço do volume de biogás produzido para o mesmo tempo de reação.

A máxima taxa de produção de biogás foi de $113,0 \mathrm{~mL}_{\text {Biogás. }} \mathrm{gSTV}^{-1}$.dia ${ }^{-1}$ na batelada 05 (Fase 01 - taxa de recirculação igual a 12 ciclos por dia) e 119,8 mL Biogás.9STV ${ }^{1}$.dia ${ }^{-1}$ na batelada 09 (Fase 02 - taxa de recirculação igual a 24 ciclos por dia). Por outro lado, as produções totais médias de biogás nas Fases 01 e 02 foram, respectivamente, de $46.096 \pm 2.521 \mathrm{~mL}$ e $44.121 \pm 722 \mathrm{~mL}$ de biogás. Dessa forma, pode-se concluir que, a produção de biogás não foi influenciada significativamente pelo aumento da taxa de recirculação de líquidos.

Desde o início das bateladas, em todas as condições testadas, o biogás apresentou em sua composição aproximadamente $50 \%$ de metano, e esta porcentagem cresceu ao longo do tempo, atingindo cerca de $70 \%$ a $85 \%$ ao final das bateladas, com média geral de $63 \%$.

Para um estudo de caso, considerando-se uma cidade de médio porte com 100 mil habitantes e extrapolando-se os resultados obtidos para operação do sistema a 32 ${ }^{\circ} \mathrm{C}$ (sistema aquecido) e $25 \stackrel{\circ}{\circ} \mathrm{C}$ (temperatura ambiente), nota-se um excedente energético 23,6\% maior se o sistema for aquecido em comparação à operação em temperatura ambiente. Entretanto, para pequenos municípios, para o saneamento rural ou descentralizado, pode ser que um tratamento sem aquecimento seja mais adequado ou até mesmo, o excedente energético não seja significativo. Desta forma, a vantagem de se operar um reator a temperatura ambiente ou aquecê-lo, está intimamente ligado ao porte do tratamento, à sua área disponível, bem como a principal finalidade do mesmo, quer seja priorizando a utilização energética do metano ou a minimização da área necessária para o tratamento de resíduos. 
Como o sistema operou com altas taxas de recirculação de líquidos (12 e 24 ciclos por dia), a variação do $\mathrm{pH}, \mathrm{AT}$ e AVT entre os reatores hidrolítico e o filtro anaeróbio pôde ser considerada pouco relevante, pois as variações possuem as mesmas ordens de grandeza e ocorreram sem defasagens, comportando-se assim, como um sistema de mistura completa.

Propõe-se o uso da relação entre a massa equivalente total de alcalinizantes, em termos de carbonato de cálcio, em relação à massa de sólidos totais voláteis no sistema ( $\left.\mathrm{M}_{\mathrm{AT}} / \mathrm{M}_{\mathrm{STV}}\right)$, como uma forma de se avaliar a capacidade de não acidificação em um digestor anaeróbio. Assim, quanto maior for esta relação, melhor será a condição inicial de operação do sistema.

O lixiviado cumpriu o seu propósito de ser um veículo de transporte para matéria orgânica solubilizada entre o reator hidrolítico e o filtro anaeróbio, uma vez que houve transferência de matéria orgânica da fase sólida do reator hidrolítico para fase líquida recirculada, que posteriormente era consumida no filtro anaeróbio.

Apesar da reutilização do lixiviado entre as bateladas subsequentes, o sistema apresentou baixa tendência de acúmulo de matéria orgânica recalcitrante, sais e nitrogênio amoniacal.

A redução da massa seca (ST) nas Fases de Adaptação, 01, 02 e 03 foram, respectivamente, de $81,8 \% ; 76,0 \% ; 74,0 \%$ e $73,7 \%$.

Ao se comparar os teores de metais dos resíduos com os limites estabelecidos, para aplicação na agricultura, pelo Resolução CONAMA e pelo MAPA, observou-se que esses limites são atendidos pela primeira, mas não pelo segundo.

Constatou-se que apesar da separação entre as unidades de tratamento, a recirculação de líquidos permitiu a colonização de morfologias metanogênicas dos resíduos no reator hidrolítico.

A relação entre substrato total disponível e biomassa (A/M) pode ser um parâmetro importante na operação de sistemas de digestão anaeróbia de resíduos sólidos orgânicos.

Constatou-se que houve um aumento dos teores de cromo, chumbo, níquel e selênio na biomassa, ao mesmo tempo em que se observou uma redução dos teores de cobre, zinco, sódio e potássio. 
Por meio de microscopia óptica e de varredura foram identificadas na biomassa morfologias hidrolíticas, tais como cocos e bacilos, e metanogênicas, como methanosaetas, bacilos, cocos e methanobrevibacter.

Destarte, pode-se concluir que o sistema de reatores proposto, em qualquer uma das condições testadas, possui potencial para ser utilizado no tratamento da fração orgânica dos resíduos sólidos urbanos. 


\section{SUGESTÕES PARA TRABALHOS FUTUROS}

Visando a continuidade das pesquisas e aprimoramento do sistema proposto, sugere-se para os trabalhos futuros:

$\checkmark$ Utilização da relação $\mathrm{M}_{\mathrm{AT}} / \mathrm{M}_{\mathrm{STV}}$ para avaliar a capacidade de não acidificação em um digestor anaeróbio;

$\checkmark$ Determinar a capacidade máxima de tratamento de resíduos deste sistema de reatores, por meio da variação progressiva da massa inicial de resíduos a ser tratada;

$\checkmark$ Verificar se a operação do reator hidrolítico com temperatura superior à do filtro anaeróbio poderia levar a um aumento da taxa de hidrólise, de forma a aumentar a eficiência do sistema, mesmo mantendo-se o filtro anaeróbio à temperatura ambiente, reduzindo-se assim os custos operacionais do sistema;

$\checkmark$ Realizar a modelagem matemática da digestão anaeróbia considerando-se esta configuração de reator, a fim de se obter parâmetros cinéticos para projeto;

$\checkmark$ Fazer ensaios em escala piloto; Avaliar a viabilidade econômica desse sistema;

$\checkmark$ Caracterizar os resíduos em proteínas, carboidratos, celulose e verificar a remoção de cada uma das frações;

$\checkmark$ Avaliar formas de pré-tratamento para matéria orgânica, como por exemplo o uso de enzimas para degradação da celulose e/ou tratamento térmico com o objetivo de se acelerar a digestão anaeróbia, reduzindo-se os tempos de reação;

$\checkmark$ Realizar o tratamento posterior do resíduo digerido para aproveitamento do biofertilizante;

$\checkmark$ Adaptar o sistema para operação continua; e,

$\checkmark$ Verificar a possibilidade de se retirar o filtro anaeróbio (sistema de fase única), utilizando ainda o lodo como inóculo e o lixiviado como líquido de recirculação em uma taxa elevada. 


\section{REFERÊNCIAS BIBLIOGRÁFICAS}

ABNT. NBR 10.004. Classificação de resíduos sólidos. Rio de Janeiro, 2004.

ABNT. NBR 8419 - Apresentação de projetos de aterros sanitários de resíduos sólidos urbanos. Rio de Janeiro, 1992.

ABNT. NBR 8849. Apresentação de projetos de Aterros Controlados de resíduos sólidos urbanos. Rio de Janeiro, 1985.

ABRELPE. Panorama dos Resíduos Sólidos no Brasil 2007 (2008). Disponível em: http://www.abrelpe.org.br/Panorama/panorama2007.pdf Acesso em: 15 nov. 2014

Panorama dos Resíduos Sólidos no Brasil 2008 (2009). Disponível em: http://www.abrelpe.org.br/Panorama/panorama2008.pdf Acesso em: nov. 2014

Panorama dos Resíduos Sólidos no Brasil 2009 (2010). Disponível em: http://www.abrelpe.org.br/Panorama/panorama2009.pdf Acesso em: 15 nov. 2014

Panorama dos Resíduos Sólidos no Brasil 2010 (2011). Disponível em: http://www.abrelpe.org.br/Panorama/panorama2010.pdf Acesso em: nov. 2014

Panorama dos Resíduos Sólidos no Brasil 2011 (2012). Disponível em: http://www.abrelpe.org.br/Panorama/panorama2011.pdf Acesso em: 15 nov. 2014

Panorama dos Resíduos Sólidos no Brasil 2012 (2013). Disponível em: http://www.abrelpe.org.br/Panorama/panorama2012.pdf Acesso em: 15 nov. 2014

Panorama dos Resíduos Sólidos no Brasil 2013 (2014). Disponível em: http://www.abrelpe.org.br/Panorama/panorama2013.pdf Acesso em: 15 nov. 2014

Panorama dos Resíduos Sólidos no Brasil 2014 (2015). Disponível em: http://www.abrelpe.org.br/Panorama/panorama2014.pdf Acesso em: 14 fev. 2016

ADORNO, M.A.T. e TOMITA, I., Desenvolvimento e validação de método para determinação de nitrogênio, hidrogênio, metano e gás carbônico por $\mathrm{CG} / \mathrm{DCT}$. $37^{\mathrm{a}}$ Reunião Anual da Sociedade Brasileira de Química.

AGAMA (2007) Integrated biogas solutions. Version 2.0

Disponível em:

http://www.90x2030.org.za/oid\%5Cdownloads\%5CAgama\%20Biogas\%20technology\%20an d\%20applications.pdf

AIT/UNEP RRC.AP - REGIONAL RESOURCE CENTER FOR ASIA AND THE PACIFIC. Municipal waste management report: Status-quo and Issues in Southeast and East Asian Countries. Asian Institute of Technology 3rd Floor, Outreach Building P.O. Box 4, Klong Luang, Pathumthani 12120, Thailand 2011. Disponível em: 
http://www.environment-health.asia/userfiles/file/Municipal\%20Waste\%20Report.pdf, acessado em 07 jan. 2015.

ALCÂNTARA, A. J. O. Composição gravimétrica dos resíduos sólidos urbanos e caracterização química do solo da área de disposição final do município de CáceresMT. Cáceres: UNEMAT, 2010. 88 p. (Dissertação - Mestrado em Ciências Ambientais). Disponível em: http://www.unemat.br/prppg/ppgca/teses/2010/02.pdf

ALEXANDER, N. European and German Waste Policy. Ecologic Institute. Pfalzburger Str. 43-44, D-10717 Berlin, 2013. Disponível em:

http://www.ecologic.eu/sites/files/presentation/2013/AXN Abfall EN.pdf

ANDRADE NETO, C. O; CAMPOS, J. R.; ALÉM SOBRINHO, P.; CHERNICHARO, C. A. L.; Nour, E. A. Filtros anaeróbios. In: Campos, J. R. (coordenador) Tratamento de esgotos sanitários por processo anaeróbio e disposição controlada no solo. Rio de Janeiro, 1999, $435 \mathrm{p}$.

ANDRADE, H. F.; PRADO, M. L. Caracterização física dos resíduos sólidos domésticos do município de Caldas Novas - GO. Goiânia. Universidade Católica de Goiás Departamento de Engenharia - Engenharia Ambiental, 2004/1. Disponível em:

http://www.ucg.br/ucg/prope/cpgss/ArquivosUpload/36/file/Continua/CARACTERIZA\%C3\%8 7\%C3\%830\%20F\%C3\%8DSICA\%20DOS\%20RES\%C3\%8DDUOS\%20S\%C3\%93LIDOS\% 20URBANOS\%20DO\%20MUNI\%E2\%80\%A6.pdf

ANDREOTTOLA, G.; CANNAS, P. Chemical and Biological Characteristics of Landfill Leachate. In: Christensen, T.; Cossu, R.; Stegmann, R. Landfilling of Waste: Leachate. Great Britain, Chapman \& Hall, 1992, p. 65-88.

ANFRUNS, A. et al .Coupling anammox and advanced oxidation-based technologies for mature landfill leachate treatment. Journal of Hazardous Materials, 27-34, 2013.

APHA; AWWA; WEF. Standard Methods for the Examination of Water and Wastewater. $21^{\text {th }}$ Edition. Washington: American Public Health Association, 2005. 1368p.

ARIUNBAATAR, J. Pretreatment methods to enhance anaerobic digestion of organic solid waste. Applied Energy 123 (2014) 143-156.

BETIM, PM. Plano municipal de resíduos sólidos. Prefeitura Municipal de Betim, Secretaria Municipal De Infraestrutura, 2010. Disponível em:

http://www.betim.mg.gov.br/portalservicos/arquivos/Plano da Politica Municipal de Residu os Solidos BETIM.pdf

BJÖRSSON, L. Environmental Biotechnology. Lund, Lunds Tekniska Högskola. Apostila para a disciplina do Departamento de Biotecnologia (Biotek) - KBT080 Environmental Biotechnology. 2012.

BIDONE, F.R.A. e POVINELLI, J. Conceitos básicos de Resíduos Sólidos. EESC USP, Projeto REENGE, Escola de Engenharia de São Carlos. São Carlos, 1999. 
BOUALLAGUI, $\mathrm{H}$. et al. Bioreactor performance in anaerobic digestion of fruit and vegetable wastes. Review. Process Biochemistry 40 (2005) 989-995.

BRASIL. Política Nacional de Resíduos Sólidos, Lei 12.305. Diário Oficial da República Federativa do Brasil, Brasília, DF, 2 ago. 2010a. Disponível em:

http://www.planalto.gov.br/ccivil 03/ ato2007-2010/2010/lei/l12305.htm

Acesso em: nov. 2014.

BRASIL. Política Nacional de Resíduos Sólidos, Decreto № 7.404. Diário Oficial da República Federativa do Brasil, Brasília, DF, 23 dez. 2010b. Disponível em:

http://www.planalto.gov.br/ccivil 03/ ato2007-2010/2010/Decreto/D7404.htm

Acesso em: nov. 2014.

BRUNETTI JUNIOR, A.; Planos municipais de gestão integrada de resíduos sólidos. Fórum Permanente Meio Ambiente e Sociedade. Avanços e Desafios da Política Nacional de Resíduos Sólidos, 2013. Disponível em:

http://www.foruns.unicamp.br/foruns/projetocotuca/biblioteca virtual/arquivos/Agamemnon\% 20Brunetti\%20Junior.pdf

Campinas, PM. Plano municipal de gestão integrada de resíduos sólidos. PMGI-RSU. VOLUME I - Diagnóstico Operacional. Prefeitura Municipal de Campinas Secretaria de Infraestrutura. Departamento de Limpeza Urbana - 2012. I Disponível em:

http://www.campinas.sp.gov.br/arquivos/diagnostico pgi rsu campinas.pdf

CANO, R.; NIELFA, A.; FDZ-POLANCO, M. Thermal hydrolysis integration in the anaerobic digestion process of different solid wastes: Energy and economic feasibility study. Bioresource Technology 168 (2014) 14-22.

CARNEIRO, P. H. Efeito da adição de lodo ao inóculo de reator anaeróbio híbrido sólido-líquido tratando fração orgânica de resíduos sólidos urbanos. Dissertação. Escola de Engenharia de São Carlos, Universidade de São Paulo, São Carlos, 2005.

CARVALHO, J. L. V.;JESUS, S. C.; PORTELLA, R. B. Composição gravimétrica dos resíduos sólidos domiciliares e comerciais do centro da cidade de Barreiras - Bahia. Revista Pesquisa Urbana, 2011. ISSN: 2178-1699. Disponível em:

http://www.chaourbano.com.br/visualizarArtigo.php?id=65

CARVALHO, P. L. Caracterização física dos resíduos sólidos domiciliares do município de Hidrolândia - GO. Universidade Católica de Goiás - Departamento de Engenharia - Engenharia Ambiental (2005). Disponível em:

http://www.ucg.br/ucg/prope/cpgss/ArquivosUpload/36/file/Continua/CARACTERIZA\%C3\%8 7\%C3\%830\%20F\%C3\%8DSICA\%20DOS\%20RES\%C3\%8DDUOS\%20S\%C3\%93LIDOS\% 20DOMICILIARES\%20\%20D\%E2\%80\%A6.pdf

CEMPRE - COMPROMISSO EMPRESARIAL PARA RECICLAGEM. Lixo Municipal: manual de gerenciamento integrado. Cordenação: André Vilhena, 3ed. São Paulo, 2010. 
CESARO, A.; BELGIORNO, V. Sonolysis and ozonation as pretreatment for anaerobic digestion of solid organic waste. Ultrasonics Sonochemistry 20 (2013) 931-936.

CESARO, A.; BELGIORNO, V. Pretreatment methods to improve anaerobic biodegradability of organic municipal solid waste fractions. Review. Chemical Engineering Journal 240 (2014) 24-37.

CETESB - COMPANHIA AMBIENTAL DO ESTADO DE SÃO PAULO. Inventário estadual de resíduos sólidos urbanos 2013. São Paulo, 2014. Disponível em:

www.cetesb.sp.gov.br/userfiles/file/residuos-solidos/residuosSolidos2013.pdf

CHARLES, W.; WALKER, L.; CORD-RUWISCH, R. Effect of pre-aeration and inoculum on the start-up of batch thermophilic anaerobic digestion of municipal solid waste. Bioresource Technology 100 (2009) 2329-2335.

CHERNICHARO, C. A. L. Princípios do tratamento biológico de águas residuárias. Reatores anaeróbios. Volume 5. Departamento de Engenharia Sanitária e Ambiental-DESA da UFMG.1997.

COELHO, T. C. ; ALENCAR, R.; OLIVEIRA, R. M. S. Caracterização física dos resíduos sólidos de palmas-to destinados ao aterro sanitário municipal. Periódico eletrônico Fórum Ambiental da Alta Paulista. V. 07, N. 12, 2011. Disponível em:

http://www.amigosdanatureza.org.br/publicacoes/index.php/forum ambiental/article/viewFile/ $\underline{215 / 214}$

COMCAP - COMPANHIA MELHORAMENTOS DA CAPITAL. Caracterização física dos resíduos sólidos urbanos de Florianópolis. Relatório Final, Florianóplis-SC (2002). Disponível em:

http://www.pmf.sc.gov.br/arquivos/arquivos/pdf/04 122009 16.43.20.3c8dbbc3ec4faf520fb $\underline{12678 f a e a 9 b e 3 . p d f}$

CONAMA - CONSELHO NACIONAL DO MEIO AMBIENTE. Resolução no 375/06. Define critérios e procedimentos, para o uso agrícola de lodos de esgoto gerados em estações de tratamento de esgoto sanitário e seus produtos derivados, e dá outras providências. Brasília, MMA, 2006. Disponível em: http://www.mma.gov.br/port/conama/res/res06/res37506.pdf

, 2006. Resolução no 380, de 31 de outubro de 2006. Retifica o Anexo I da Resolução CONAMA no 375/06. 2 p. Disponível em:

http://www.mma.gov.br/port/conama/legislacao/CONAMA RES CONS 2006 380.pdf

CONTRERA, R.C. Tratamento de lixiviados de aterros sanitários em sistema de reatores anaeróbio e aeróbio operados em batelada seqüencial. São Carlos-SP, Tese de Doutorado - Escola de Engenharia de São Carlos, Universidade de São Paulo. 731 p. 2008.

COUNCIL DIRECTIVE 91/689/EEC on hazardous waste, OJ L 377 de 31/12/1991 p. 0020 $-0027$. 
COUNCIL DIRECTIVE 96/61/EC of 24 September 1996 Concerning Integrated Pollution Prevention and Control, OJ L 257, 10.10.1996, p.26.

COUNCIL DIRECTIVE 1999/31/EC of 26 April 1999 on the Landfill of Waste, OJ L 182, 16.7.1999, p.1.

COUNCIL DIRECTIVE 2000/76/EC of the European Parliament and the Council of 4 December 2000 on the incineration of waste, OJ L 332, 28.12.2000, p.91.

COUNCIL REGULATION 259/93/EEC of 1 February 1993 on the supervision and control of shipments of waste within, into and out of the European Community, OJ L 30, 6.2. 1993, pp. 1-28.

CHRISTENSEN, T. H. (Editor). Solid Waste technology \& Management. IWWG, ISWA. Wiley, 1st Edition (2011), 2 volumes.

DE BAERE, L.; MATTHEEUWS, B. Anaerobic digestion of the organic fraction of municipal solid waste in europeu - Status, Experience and Prospects.[Belgica]: 2013.

Disponível em: http://www.ows.be/wp-content/uploads/2013/02/Anaerobic-digestion-of-theorganic-fraction-of-MSW-in-Europe.pdf

DILALLO, R. E ALBERTSON, O. E. Volatile acides by direct titration. Journal Water Pollution Control Federation. V.33, n.4, p. 350-364, 1961.

DILLENBURG, M. E. Variação da taxa de recirculação de lixiviado determinada pela concentração de ácidos voláteis no tratamento da fração orgânica de resíduos sólidos urbanos domésticos. Dissertação. Escola de Engenharia de São Carlos, Universidade de São Paulo, São Carlos, 2006.

DIRECTIVE 75/442/EEC of 15 July 1975 on waste, CELEX-EUR Official Journal L 194, 25 July 1975 , pp. 39-41.

DONG, Y. Development of Waste-To-Energy in China; and Case Study of the Guangzhou Likeng WTE plant. M.S. degree in Earth Resources Engineering. Department of Earth and Environmental Engineering. Columbia University. December 2011.

EPA - U.S. Environmental Protection Agency. Municipal Solid Waste Generation, Recycling, and Disposal in the United States: Tables and Figures for 2012. U.S. Environmental Protection Agency, Office of Resource Conservation and Recovery, February 2014. Disponível em:

http://www.epa.gov/solidwaste/nonhaz/municipal/pubs/2012 msw dat tbls.pdf

EUROPEAN COMMISSION. The story behind the strategy: EU waste policy. 2014. Disponível em:

http://ec.europa.eu/environment/waste/pdf/story book.pdf - Last updated: 30/10/2014. 
FDR- FUNDAÇÃO DEMÓCRITO ROCHA. Fatores que influenciam na compostagem. 2014. Disponível em: http://fdr.com.br/formacao/compostagem-e-minhocultura/fatores-queinfluenciam-na-compostagem/ Last updated: 08/04/2014.

FEIJÓ, L. L. Tratamento enzimático de lixiviado de aterro sanitário. 89 p. Dissertação (Mestrado) Escola Politécnica, Universidade de São Paulo, São Paulo, 2015.

FERNÁNDEZ, B.; PORRIER, P.; CHAMY, R. Effect of inoculum-substrate ratio on the start-up of solid waste anaerobic digesters. Water Science and Technology - IWA: 2001. Vol 44 No 4 pp 103-108.

FLOR, A.P.C.P. Comportamento de reactores anaeróbios tratando a fracção orgânica dos resíduos sólidos urbanos. Universidade de Aveiro: Departamento de Ambiente e Ordenamento, 2006.

FRÉSCA, F. R. C. Estudo da geração dos resíduos sólidos domiciliares no Minicípio de São Carlos-SP, a partir da caracterização física. Dissertação de Mestrado, Escola de Engenharia de São Carlos - Universidade de São Paulo, São Carlos-SP, 2007.

GARCÍA, A. J. Biodegradable municipal solid waste: Characterization and potential use as animal feedstuffs. Waste Management 25 (2005) 780-787.

GÓES, H. C. Coleta seletiva, planejamento municipal e a gestão de resíduos sólidos urbanos em Macapá/AP. Planeta Amazônia: Revista Internacional de Direito Ambiental e Políticas Públicas. Macapá, n. 3, p. 45-60, 2011.

GREGO, T. I.; SCHOENHALS, M. Análise quali-quantitativa dos resíduos sólidos urbanos gerados em Marília - SP. 2009. Disponível em:

http://cacphp.unioeste.br/eventos/senama/anais/PDF/ARTIGOS/51 1269890766 ARTIGO.p $\underline{\mathrm{df}}$

HAN, Z. et al. A novel technique of semi-aerobic aged refuse biofilter for leachate treatment. Waste Management 31 (2011) 1827-1832.

HANC, A. Composition and parameters of household bio-waste in four seasons. Waste Management 31 (2011) 1450-1460.

HARPHER, S. R.; POHLAND, F. G. Enhancement of anaerobic treatment efficiency through process modification. Journal of Water Pollution Control Federation, 1997, 59: 152-161.

HASSAN, M.; XIE, BING. Use of aged refuse-based bioreactor/biofilter for landfill leachate treatment. Appl Microbiol Biotechnol (2014) 98:6543-6553.

HETTIARATCHI, J. P. A. et al. Waste degradation and gas production with enzymatic enhancement in anaerobic and aerobic landfill bioreactors. Bioresource Technology 159 (2014) 433-436. 
IBGE. Pesquisa Nacional de Saneamento Básico 2008. Ministério do Planejamento, Orçamento e Gestão, Diretoria de Pesquisas, Coordenação de População e Indicadores Sociais, Rio de Janeiro: 2010. Disponível em:

http://www.ibge.gov.br/home/estatistica/populacao/condicaodevida/pnsb2008/PNSB 2008.p $\underline{\mathrm{df}}$

INANC, B.; CALLI, B.; SAATCI, A. Characterization and anaerobic treatment of the sanitary landfill leachate in Istanbul. Water Science and Technology. vol. 41, no. 3, (2000) pp. 223-230.

IPEA. Diagnóstico dos resíduos sólidos urbanos. Relatório de Pesquisa. Secretaria de Assuntos Estratégicos da Presidência da República. Brasília, 2012. Disponível em:

http://www.ipea.gov.br/agencia/images/stories/PDFs/relatoriopesquisa/121009 relatorio resi duos solidos urbanos.pdf Acesso em: dez. 2014.

ITRC. Characterization, Design, Construction, and Monitoring of Bioreactor Landfills. Technical/Regulatory Guideline . The Interstate Technology \& Regulatory Council

Alternative Landfill Technologies Team. Washington, DC 20001: 2006. Disponível em:

http://www.sswm.info/sites/default/files/reference attachments/ITRC\%202006\%20Landfill\%2 0Bioreactor.pdf

JENSEN, J. W. et al. Enzymatic processing of municipal solid waste. Waste Management 30 (2010) 2497-2503.

JOHNSON, A. The development of waste management law. Austrália. Eastern Metropolitan Regional Council, 2004. Disponível em:

http://www.iswa.org/uploads/tx iswaknowledgebase/538338 Paper.pdf

KHANAL, S. K. Anaerobic Biotechnology for Bioenergy Produc tion: Principles and Applications. John Wiley \& Sons, Inc., 2008, 308 pp.

KIEHL, E.J. Manual de Compostagem: Maturação e Qualidade do Composto. 4⿳亠丷a ed. Piracicaba, SP. 173 p., 2004.

KING, A. Removal of Excess Cellulose and Associated Polysaccharides in Fruit and vegetable By-Products - Implication for Use in Feed for Monogastric Farm Animals. (2013) In: http://cdn.intechopen.com/pdfs-wm/45623.pdf

KJELDSEN, P.; BARLAZ, M. A. ; ROOKER, A. P.; BAUN, A.; LEDIN, A.; CHRISTENSEN, T. $\mathrm{H}$. Present and long-term composition of MSW landfill leachate: A Review. Critical Reviews in Environmental Science and Technology, 32 (4), 2002. Pages 297-336.

KUENEN, J.G. Anammox bacteria: from discovery to application. Nature Vol. 06, April, pp. 320-326, 2008.

KULIKOWSKA, D. Nitrogen removal from landfill leachate via the nitrite route. Braz. J. Chem. Eng., 29, no.2, p.211-219, 2012. 
LEME, S. M.; JOIA, P. R. Caracterização física dos resíduos sólidos urbanos domiciliares em Aquidauana - MS. Geografia - v. 15, n. 1, jan./jun. 2006 - Universidade Estadual de Londrina, Departamento de Geociências. Disponível em:

file://C:/Users/Ronan/Downloads/6643-24334-1-PB.pdf

LESTEUR, M. Alternative methods for determining anaerobic biodegradability: A review. Process Biochemistry 45 (2010) 431-440.

LETTINGA ASSOCIATES FOUNDATION. Development of decentralized anaerobic digestion systems for application in the UK. Phase 1 - Final report. 2009. Disponível em: http://www.communitycompost.org/CCN documents/Small scale AD for CCN Phase1 rep ort.pdf

$\mathrm{LI}, \mathrm{H}$. et al. Leachate treatment using a demonstration aged refuse biofilter. Journal of Environmental Sciences 2010, 22(7) 1116-1122.

LUND, H. F. McGraw-Hill Recycling Handbook. McGraw-Hill, $2^{\text {nd }}$ Ed, 2000.

MAPA - MINISTÉRIO DE ESTADO DA AGRICULTURA, PECUÁRIA E ABASTECIMENTO. Instrução Normativa no 17, de 18 de junho de 2014. Anexo VI.

MARQUES JÚNIOR, W.; PASQUALETTO, A. Caracterização física dos resíduos sólidos domésticos da cidade de bela vista - GO. Goiânia, 2005/1. Disponível em:

http://www.ucg.br/ucg/prope/cpgss/ArquivosUpload/36/file/Continua/CARACTERIZA\%C3\%8 7\%C3\%830\%20F\%C3\%8DSICA\%20DOS\%20RES\%C3\%8DDUOS\%20S\%C3\%93LIDOS\% 20DOM\%C3\%89STICOS\%20DA\%20C\%E2\%80\%A6.pdf

MATA-ALVAREZ, J.; MACÉ, S.; LLABRÉS, P. Anaerobic digestion of organic solid wastes. An overview of research achievements and perspectives. Review paper. Bioresource Technology 74 (2000) 3-16.

METCALF \& EDDY/ AECOM. Tratamento de efluentes e recuperação de recursos. McGraw-Hill Education, bookman, 5ª Ed, 2016

MILLOT, N.; COURANT, P. Treatability characteristics of landfill leachate. In Christensen, T. H.; Cossu, R.; Stegmann, R., Landfilling of waste: Leachate. Chapman \& Hall Ltd, reprinted, (1997).

MINISTRY OF THE ENVIRONMENT GOVERMENT OF JAPAN. Waste \& Recycling. 2015 Disponível em: https://www.env.go.jp/en/recycle/index.html

NAIK, N.; TKACHENKO, E.; WUNG, R. The Anaerobic Digestion of Organic Municipal Solid Waste in California. Berkeley: University of California, 2013.

Disponível em: https://bcgc.berkeley.edu/sites/default/files/Anaerobic-Digestion-report.pdf

NAYONO, S.E. Anaerobic digestion of organic solid waste for energy production. Karlsruher Institut für Technologie. Karlsure: 2010. 
Neubauer, A. European and German Waste Policy. Ecologic Institute. Ecologic Institute, Pfalzburger Str. 43-44, D-10717 Berlin, 2013.

Disponível em: http://www.ecologic.eu/sites/files/presentation/2013/AXN Abfall EN.pdf

NIELFA, A.; CANO, R. e FDZ-POLANCO, M. Theoretical methane production generated by the co-digestion of organic fraction municipal solid waste and biological sludge. Biotechnology Reports, Vol 5, pages 14-21, 2015.

OECD - ORGANISATION FOR ECONOMIC CO-OPERATION AND DEVELOPMENT (2013). Environment at a Glance 2013: OECD Indicators, OECD Publishing. Disponível em: http://dx.doi.org/10.1787/9789264185715-en

OLIVEIRA, S. A.; LEITE, V. D.; PRASAD, S.; RIBEIRO, M. D. Caracterização física e química dos resíduos sólidos domiciliares da cidade de Campina Grande/PB. 23을 Congresso Brasileiro de Engenharia Sanitária e Ambiental, 2005. Disponível em:

http://www.bvsde.paho.org/bvsacd/abes23/lll-101.pdf

OLIVEIRA, S. Gestão dos resíduos sólidos urbanos na microrregião homogênea Serra de Botucatu - Caracterização física dos resíduos sólidos domésticos na cidade de Botucatu/SP. 127 pp.. Dissertação (mestrado) -- Universidade Estadual Paulista, Faculdade de Ciências Agronômicas, Botucatu, 1997. Disponível em:

http://base.repositorio.unesp.br/bitstream/handle/11449/90707/oliveira s me botfca.pdf?seq uence $=1$

PICANÇO, A. P. Influência da recirculação de percolado em sistemas de batelada de uma fase e híbrido na digestão da fração orgânica de resíduos sólidos urbanos. Tese (Doutorado) - Escola de Engenharia de São Carlos, Universidade de São Paulo, São Carlos, 2004.

PICANÇO, F.; TELLO, J. C. R.; L COELHO, L. M. Caracterização física dos resíduos sólidos urbanos produzidos na cidade de Parintins - AM. Revista Ibero-Americana de Ciências Ambientais (ISSN 2179-6858), v. 5, n. 2 . 2014. Disponível em:

http://sustenere.co/journals/index.php/rica/article/view/Sustenere2179-6858.2014.002.0010

PINHEIRO, A.; POLZ, J. A. Considerações sobre os resíduos sólidos do município de Blumenau (SC). VI Simpósio Ítalo Brasileiro de Engenharia Sanitária e Ambiental, 2002. Disponível em: http://www.bvsde.paho.org/bvsacd/sibesa6/clii.pdf .

PREFEITURA MUNICIPAL DE SÃO PAULO. Gestão dos resíduos sólidos na cidade de São Paulo. Secretaria Municipal de Serviços Departamento de Limpeza Urbana. São Paulo: 2007. Disponível em:

http://www.cetesb.sp.gov.br/noticentro/2007/10/pref saopaulo.pdf

PREFEITURA DO MUNICÍPIO DE SÃO PAULO - LIMPURB. Caracterização gravimétrica e físico - química dos resíduos sólidos domiciliares do município de São Paulo. São Paulo, 2003. Disponível em:

http://www.bvsde.paho.org/bvsacd/cd48/RelatorioGeral2003.pdf 
PROBIOGÁS - PROJETO BRASIL ALEMANHA DE FOMENTO AO APROVEITAMENTO ENERGÉTICO DO BIOGÁS. Guia Prático do Biogás: Geração e Utilização. Agência Alemã de Cooperação Internacional GIZ e a Secretária Nacional de Saneamento Ambiental do Ministério das Cidades. Publicado pela Fachagentur Nachwachsende Rohstoffe e. V. (FNR), com o apoio do Ministério da Nutrição, Agricultura e Defesa do Consumidor da Alemanha. 5a ed., Gülzow, 2010. FNR 2013. Disponível em:

http://www.resol.com.br/cartilhas/giz - guia pratico do biogas final.pdf

QASIM, S.; CHIANG, W. Sanitary landfill leachate: Generation, control and treatment. Technomic Publishing Company, Inc.. Lancaster, Pensylvania, USA, 1994.

RAJESHWARI KV, PANTH DC, LATA K, KISHORE VVN. Novel process using enhanced acidification and a UASB reactor for biomethanation of vegetable market waste. Waste Manage Res 2001;1:292-300.

REZENDE, J.H. et al. Composição gravimétrica e peso específico dos resíduos sólidos urbanos em Jaú (SP). Eng Sanit Ambient | v.18 n.1 | jan/mar 2013 | 1-8. Disponível em: http://www.scielo.br/pdf/esa/v18n1/a01v18n1.pdf

RIMAITYTÉ, I. et al. Energy and Environmental Indicators of Municipal Solid Waste Incineration: toward Selection of an Optimal Waste Management System. Polish J. of Environ. Stud. Vol. 19, No. 5 (2010), 989-998.

ROCHA, D. C.; OLIVEIRA, D. F. G.; SILVA, P. L. Caracterização de resíduos sólidos urbanos de Piracicaba para avaliação do potencial energético. Faculdade de Tecnologia de Piracicaba, Trabalho de conclusão de curso, 2011. Disponível em:

https://www.academia.edu/4439651/CARACTERIZA\%C3\%87\%C3\%830 DE RES\%C3\%8 DDUOS S\%C3\%93LIDOS URBANOS DE PIRACICABA PARA AVALIA\%C3\%87\%C3\%8 30 DO POTENCIAL ENERG\%C3\%89TICO .

SANTOS, F.A.; QUEIRÓZ, J.H.; COLODETTE, J.L.; FERNANDES, S.A.; GUIMARÃES, V.M. e REZENDE, S.T. Potencial da palha de cana-de-açúcar para produção de etanol. Química Nova, Vol. 35, No. 5, 1004-1010, 2012.

SNIS. Diagnóstico do Manejo de Resíduos Sólidos Urbanos 2014 (fev, 2016).

Disponível em: http://www.snis.gov.br/diagnostico-residuos-solidos/diagnostico-rs-2014 Acesso em: fev. 2016.

SOUTO, G. D. B. Lixiviados de aterros sanitários brasileiros - Estudo de remoção do nitrogênio amoniacal por processo de arraste com ar (stripping). São Carlos-SP, 2009. Tese de Doutorado - Escola de Engenharia de São Carlos, Universidade de São Paulo.

SPEECE, R. E. Anaerobic biotechnology for industrial wastewaters. NashvilleTennessee, 1996. Archae press.

TABALIPA, N. L.; FIORI, A.P. Caracterização e classificação dos resíduos sólidos urbanos do município de Pato Branco, PR. Revista Brasileira de Ciências Ambientais número 4, agosto de 2006. Disponível em:

http://www.rbciamb.com.br/images/online/04 artigo 3 artigos89.pdf 
TCHOBANOGLOUS, G.; THEISEN, H.; VIGIL, S. A. Integrated solid waste management: Engineering principles and management issues. E.U.A., McGraw-Hill, 978 pp. 1993.

TIMUR, H.; ÖZTURK, I. Anaerobic treatment of leachate using sequencing batch reactor and hybrid bed filter. Water science and Technology, vol. 36, No. 6-7, pp 501-508, 1997.

TIMUR, $\mathrm{H}$ et al. Anaerobic treatability of leachate: a comparative evaluation for three different reactor systems. Water science and Technology, vol. 42, No. 1-2, (2000) pp 287292.

TONINI, D.; ASTRUP, T. Life-cycle assessment of a waste refinery process for enzymatic treatment of municipal solid waste. Waste Management 32 (2012) 165-176.

UNEP. Waste - Investing in energy and resource efficiency. Green Economy. Germany, 2011. Acessado em 07 jan. 2015. Disponível em:

http://www.unep.org/greeneconomy/Portals/88/documents/ger/GER 8 Waste.pdf

VAN DER STAR, W.R.L. et al. Startup of reactors for anoxic ammonium oxidation: Experiences from the first full-scale anammox reactor in Rotterdam. Wat. Res. 41, 4149- 4163, 2007.

VAN HAANDEL, A.; MARAIS, G. O comportamento do Sistema de Lodo Ativado. Campina Grande, epgraf, 1999. 488p. il 118.

VANDEVIVERE, P.; DE BAERE, L.; VERSTRAETE, W. Types of anaerobic digesters for solid wastes. In Biomethanization of Biomethanization of the organic fractionof municipal solid wastes - OFMSW. Published by IWA Publishing, Alliance House, 12 Caxton Street, London SW1H 0QS, UK, 2003. Edited by J. Mata-Alvarez. Disponível em:

https://www.adelaide.edu.au/biogas/anaerobic digestion/pvdv.pdf

VERMA S. Anaerobic digestion of biodegradable organics in municipal solid wastes. Columbia University - Department of Earth \& Environmental Engineering. 50 p. Dissertação (Mestrado). 2002.

VILELA, F. R. Biometanização: estudo da influência do lodo e da serragem no tratamento anaeróbio da fração orgânica dos resíduos sólidos urbanos (FORSU). 2015. 207 f. Dissertação (Mestrado) - Escola de Engenharia de São Carlos, Universidade de São Paulo, São Carlos, 2015.

$\mathrm{XIE}$, B. et al. Performance and bacterial compositions of aged refuse reactors treating mature landfill leachate. Bioresource Technology 103 (2012) 71-77.

WAN, S. et al. Anaerobic digestion of municipal solid waste composed of food waste, wastepaper, and plastic in a single-stage system: Performance and microbial community structure characterization. Bioresource Technology 146 (2013) 619-627. 
WANG, K. et al. Advanced nitrogen removal from landfill leachate without addition of external carbon using a novel system coupling ASBR and modified SBR. Bioresource Technology 134, 212-218, 2013.

WILLIAMS, P. T. Waste Treatment ande Disposal. Jonh Wiley \& Sons Itd. 2nd ed. Great Britain, 2005. 380p.

WM - WASTE MANAGEMENT. The Bioreactor Landfill. Cincinnati: Waste Management (WM) Bioreactor Programm. Cincinnati, OH 45211: 2004. Disponível em:

http://www.sswm.info/sites/default/files/reference attachments/WM\%202004\%20The\%20Bio reactor\%20Landfill.pdf

ZAHER, U. et al. Producing Energy and Fertilizer From Organic Municipal Solid Waste. Department of Biological Systems Engineering Washington State University. Project Deliverable \# 1. June 26, 2007. Disponível em:

https://fortress.wa.gov/ecy/publications/publications/0707024.pdf

ZHAO, J.; ZHENG, Y.; YEBO LI. Fungal pretreatment of yard trimmings for enhancement of methane yield from solid-state anaerobic digestion. Bioresource Technology 156 (2014) 176-181.

ZHANG, R. et al. Characterization of food waste as feedstock for anaerobic digestion. Bioresource Technology 98 (2007) 929-935.

ZHANG, L.; JAHNG, D. Long-term anaerobic digestion of food waste stabilized by trace elements. Waste Management 32 (2012) 1509-1515.

$\mathrm{ZHU}$, R. et al. Biological nitrogen removal from landfill leachate using anaerobicaerobic process: Denitritation via organics in raw leachate and intracellular storage polymers of microorganisms. Bioresource Technology, 128, 401-408, 2013. 


\section{APÊNDICE A - RESULTADOS ADICIONAIS}

\section{Série de Sólidos}

Figura 57 - Variações das concentrações de Sólidos Totais nas diferentes fases do experimento.

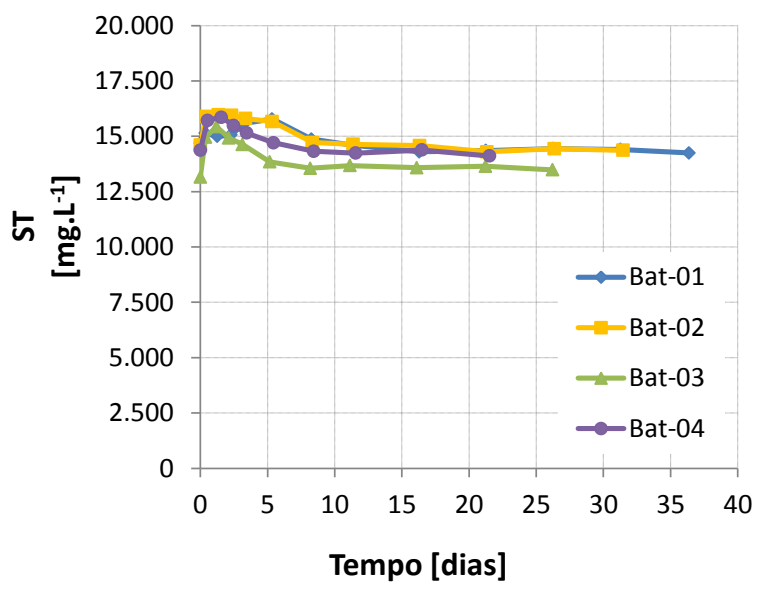

(a) Na Fase de Adaptação

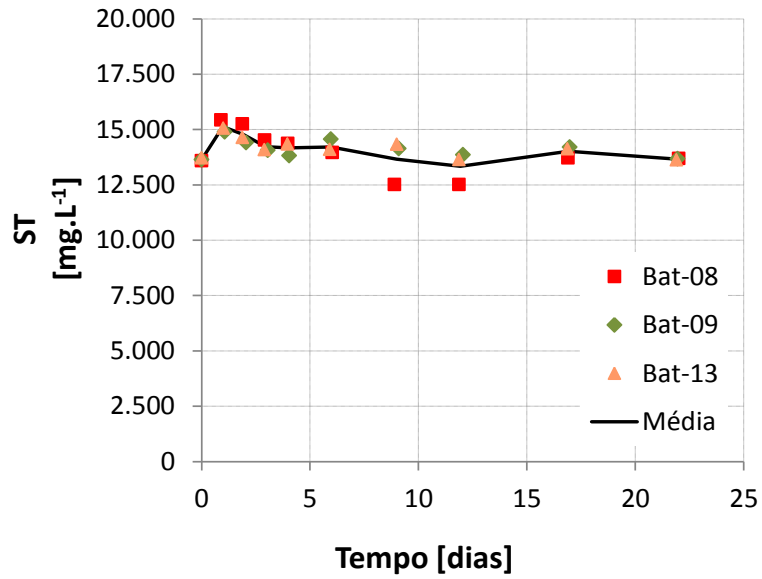

(c) Na Fase 2 a 24 ciclos por dia e $32^{\circ} \mathrm{C}$

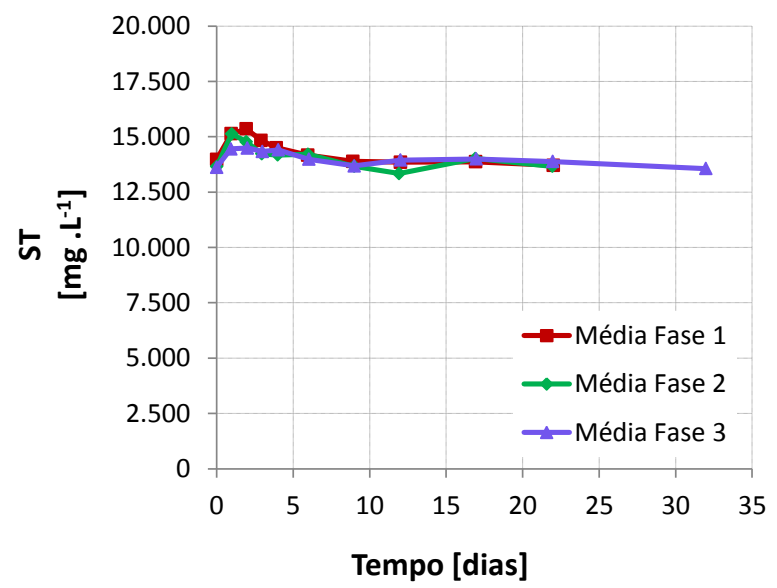

(e) Comparação entre as médias das Fases 1, 2 e 3

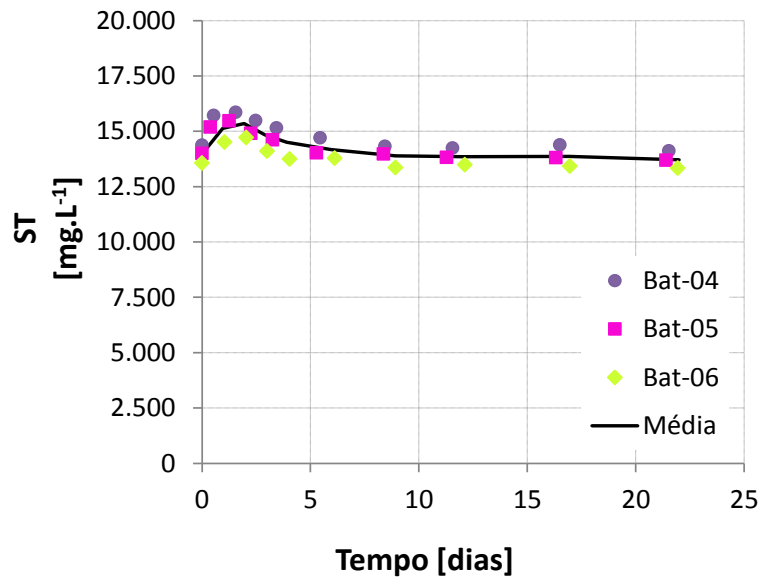

(b) Na Fase 1 a 12 ciclos por dia e $32^{\circ} \mathrm{C}$

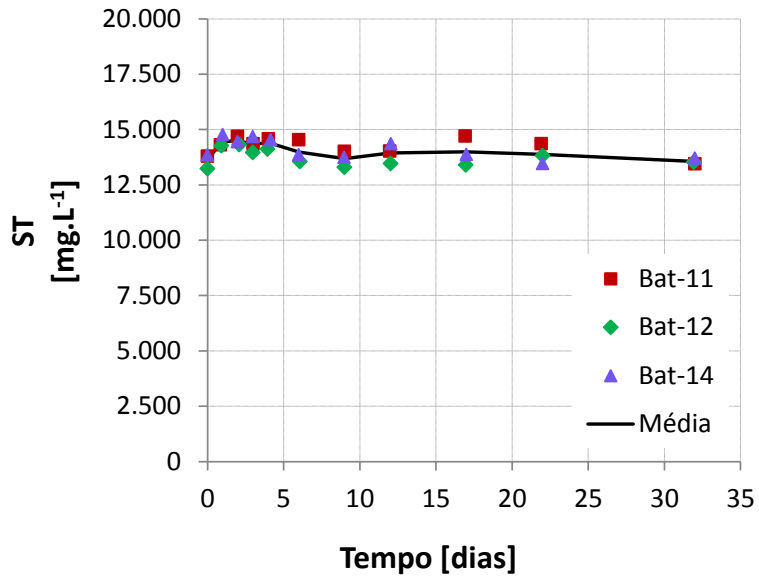

(d) Na Fase 3 a 24 ciclos por dia e $25^{\circ} \mathrm{C}$

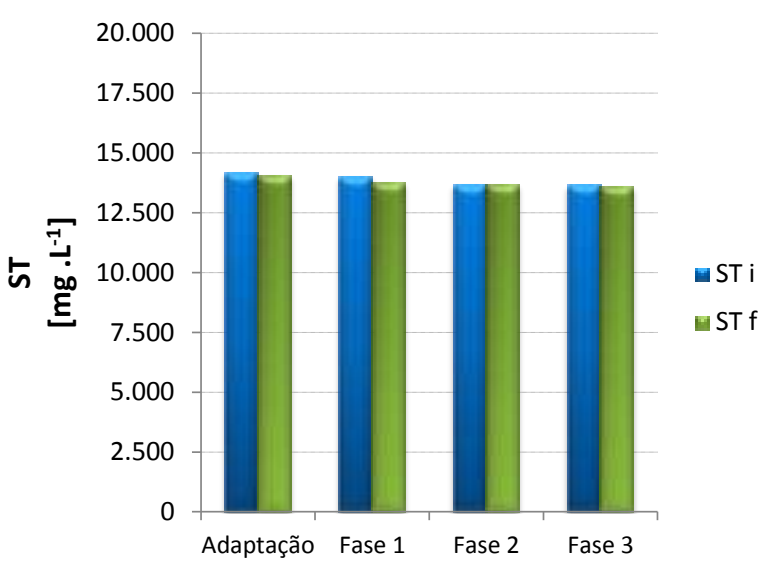

(f) Inicial e final nas quatro fases 
Figura 58 - Variações das concentrações de Sólidos Totais Voláteis nas diferentes fases do experimento fases.

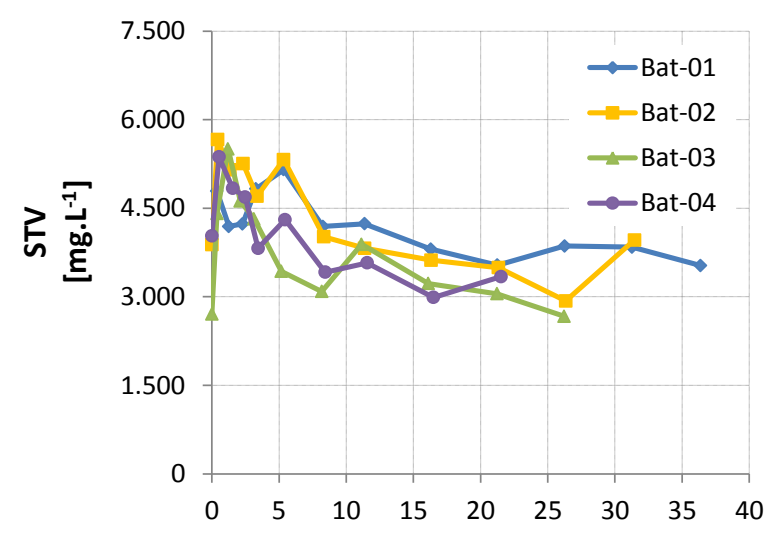

Tempo [dias]

(a) ) Na Fase de Adaptação

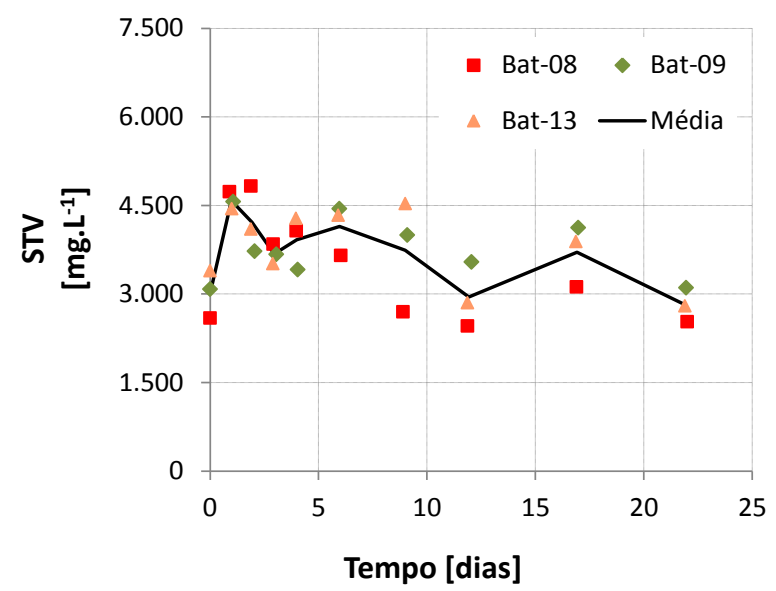

(c) Na Fase 2 a 24 ciclos por dia e $32^{\circ} \mathrm{C}$

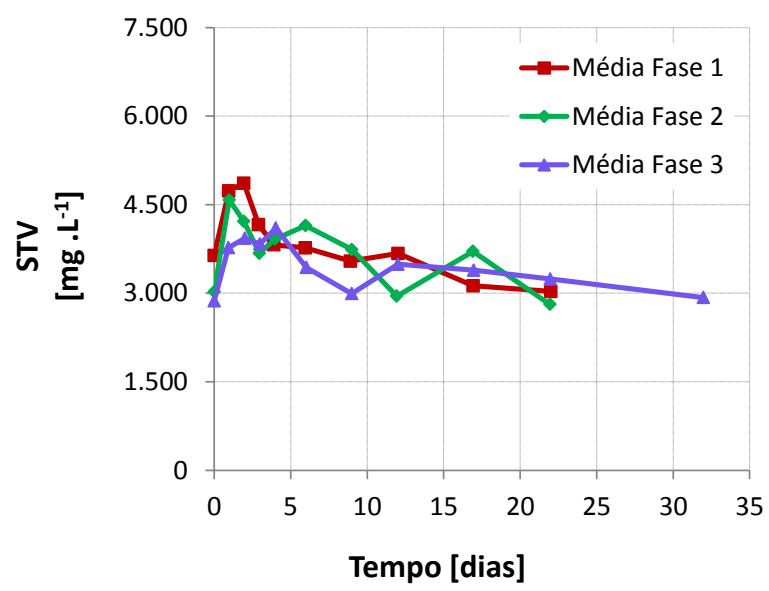

(e) Comparação entre as médias das Fases 1, 2 e 3

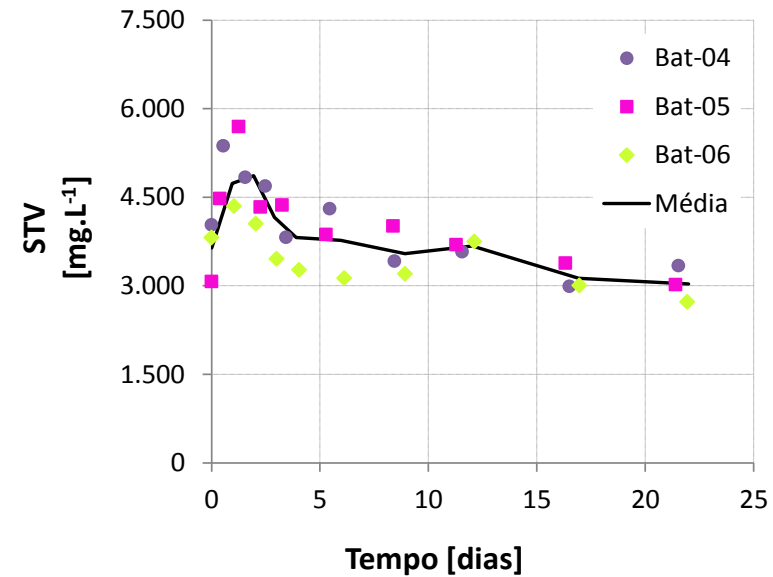

(b) Na Fase 1 a 12 ciclos por dia e $32^{\circ} \mathrm{C}$

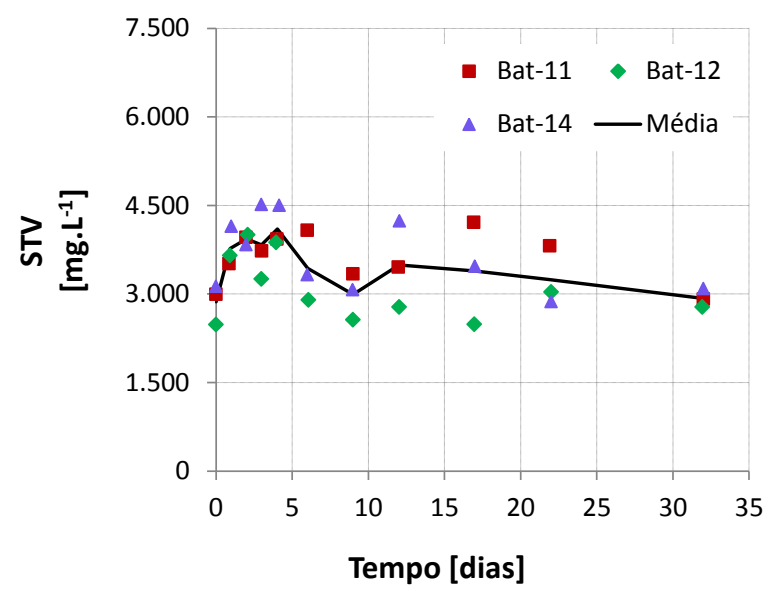

(d) Na Fase 3 a 24 ciclos por dia e $25^{\circ} \mathrm{C}$

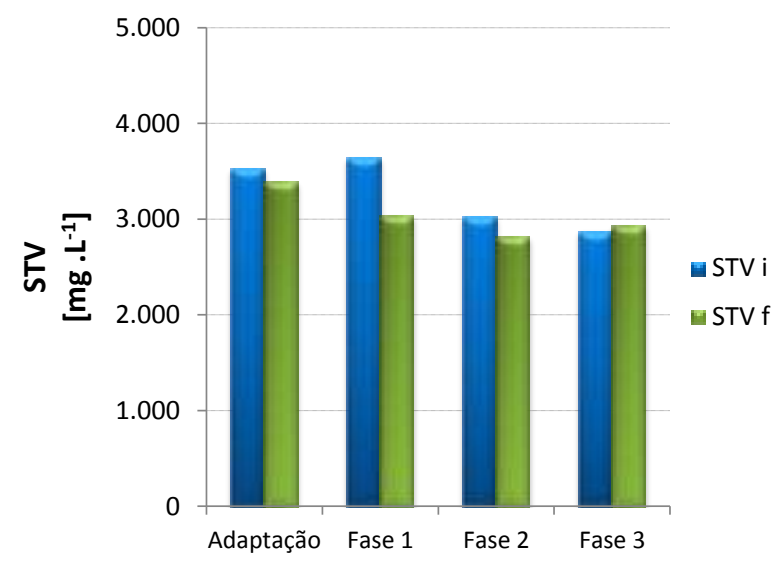

(f) Inicial e final nas quatro fases 
Figura 59 - Variações das concentrações de Sólidos Totais Fixos nas diferentes fases do experimento.

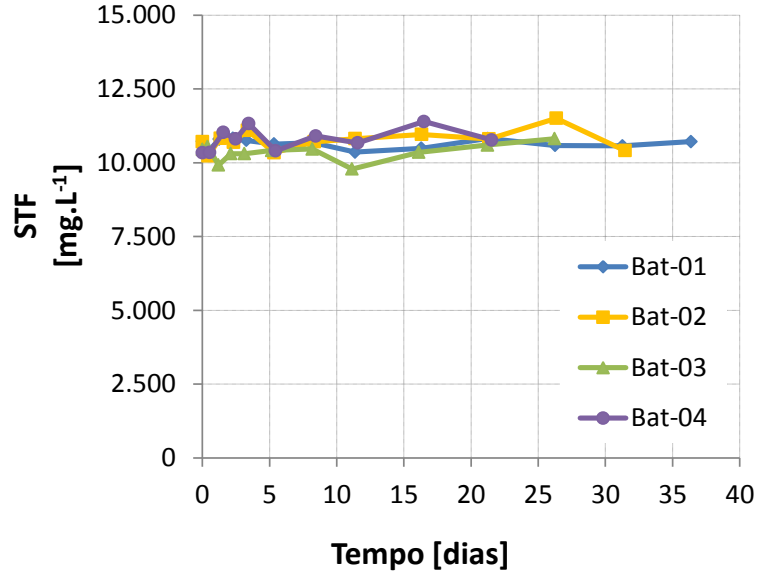

(a) Na Fase de Adaptação

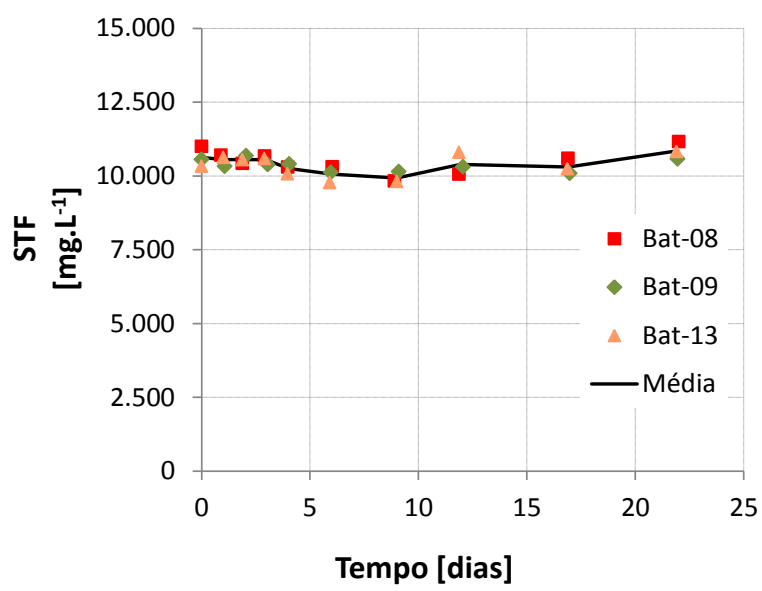

(c) Na Fase 2 a 24 ciclos por dia e $32^{\circ} \mathrm{C}$

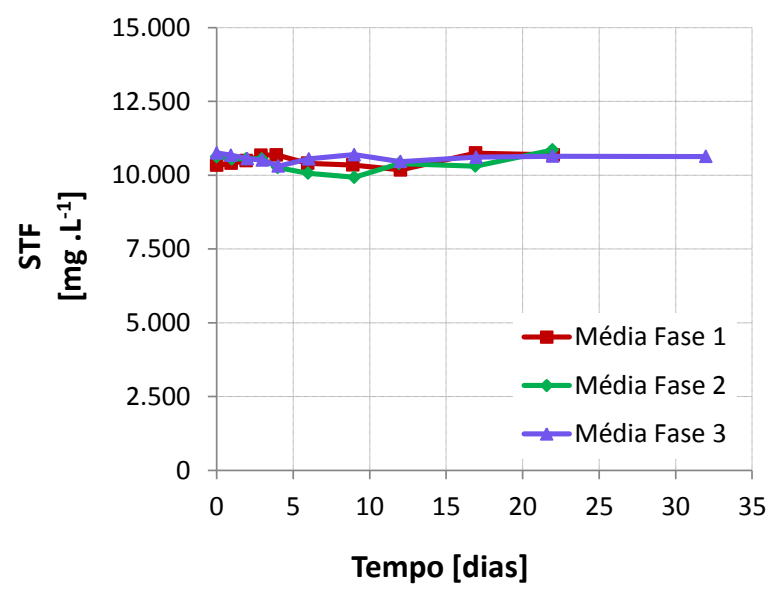

(e) Comparação entre as médias das Fases 1, 2 e 3

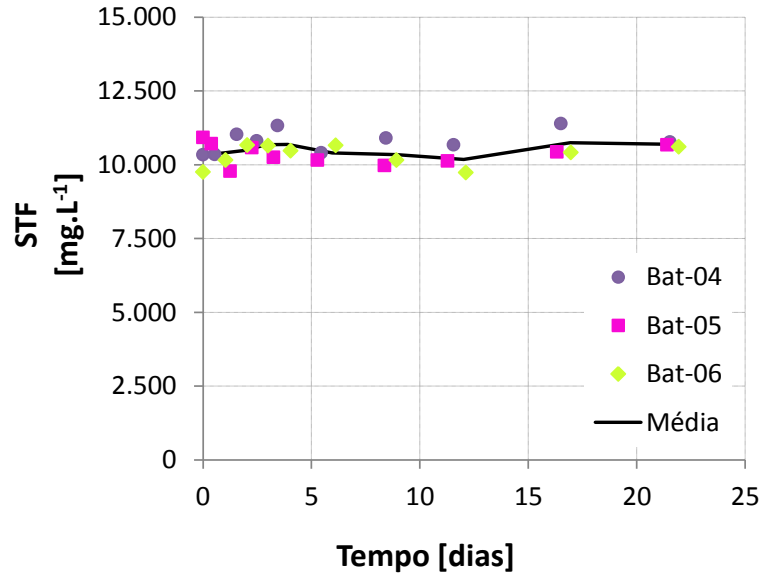

(b) Na Fase 1 a 12 ciclos por dia e $32^{\circ} \mathrm{C}$

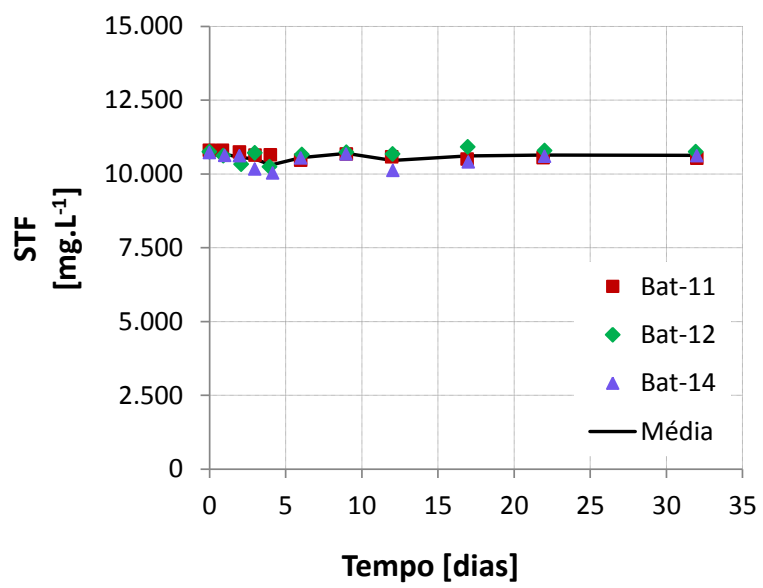

(d) Na Fase 3 a 24 ciclos por dia e $25^{\circ} \mathrm{C}$

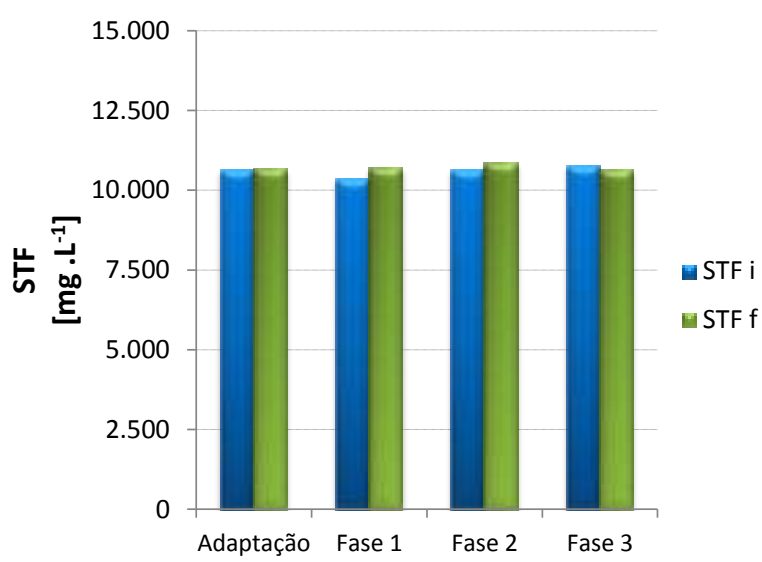

(f) Inicial e final nas quatro fases 
Figura 60 - Variações das concentrações de Sólidos em Suspensão Fixos nas diferentes fases do experimento.

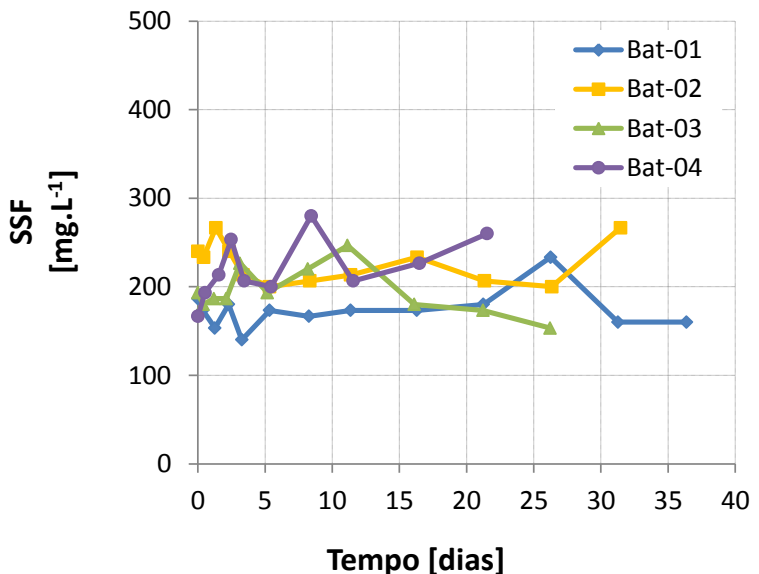

(a) Na Fase de Adaptação

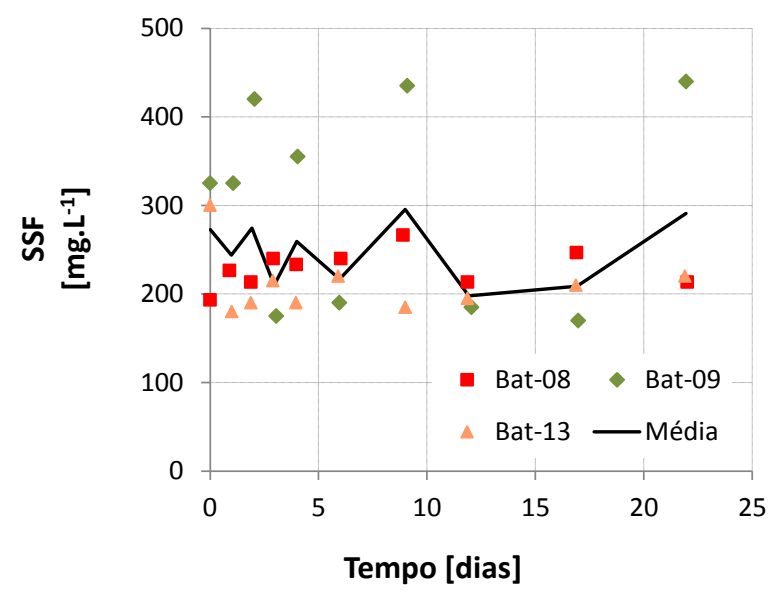

(c) Na Fase 2 a 24 ciclos por dia e $32^{\circ} \mathrm{C}$

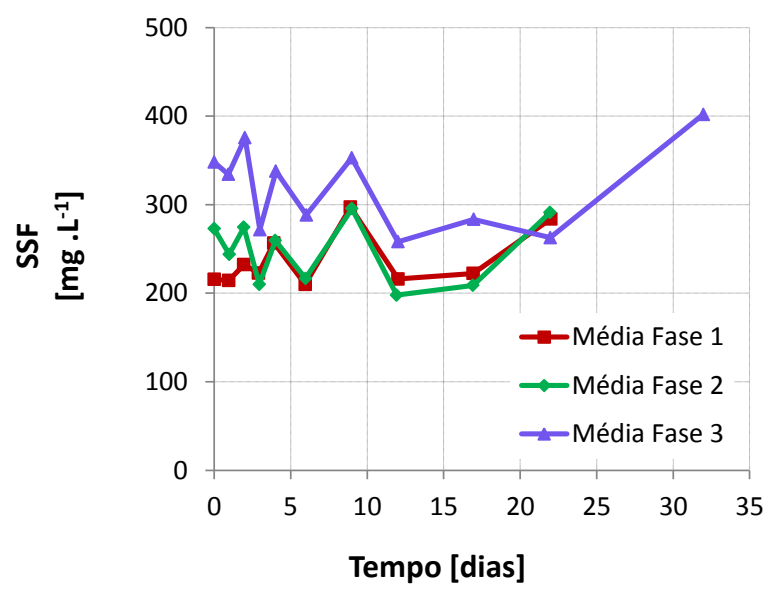

(e) Comparação entre as médias das Fases 1, 2 e 3

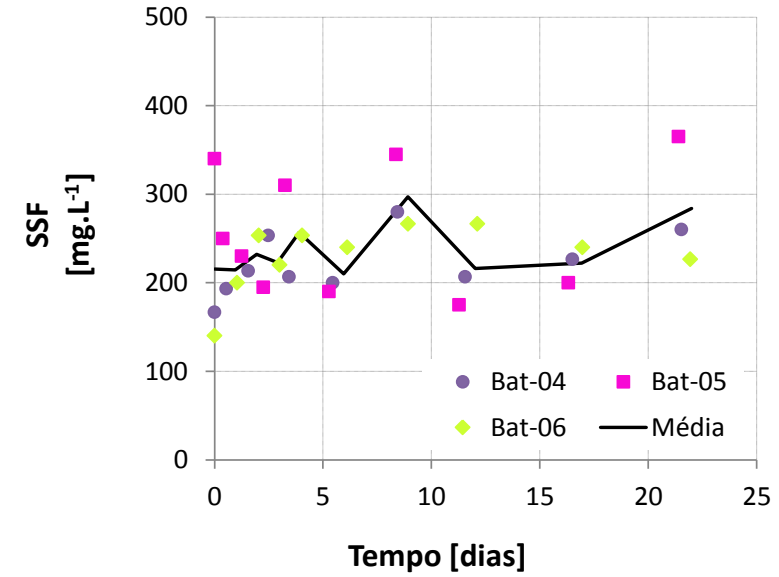

(b) Na Fase 1 a 12 ciclos por dia e $32^{\circ} \mathrm{C}$

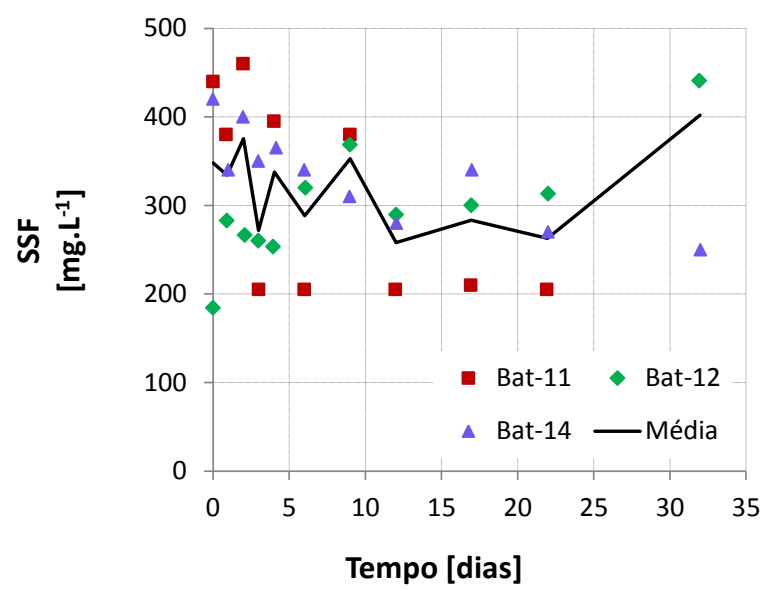

(d) Na Fase 3 a 24 ciclos por dia e $25^{\circ} \mathrm{C}$

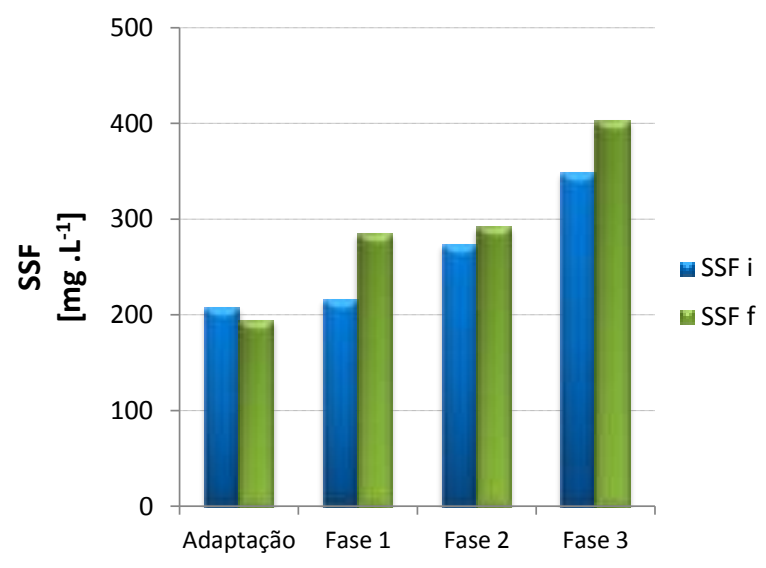

(f) Inicial e final nas quatro fases 
Figura 61 - Variações das concentrações de Sólidos Suspensos Totais nas diferentes fases do experimento.

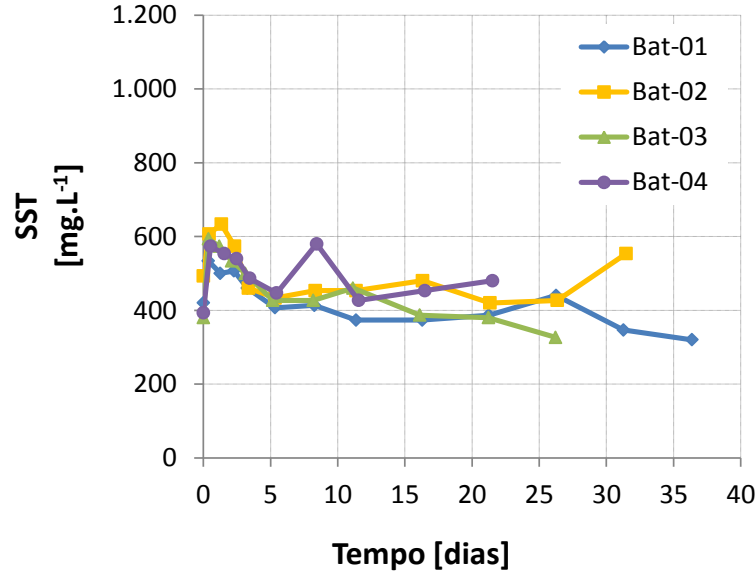

(a) Na Fase de Adaptação

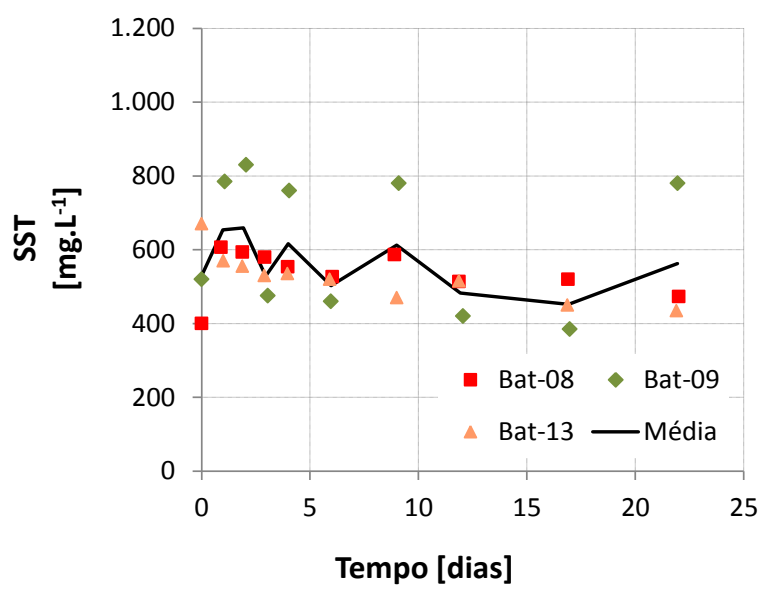

(c) Na Fase 2 a 24 ciclos por dia e $32^{\circ} \mathrm{C}$

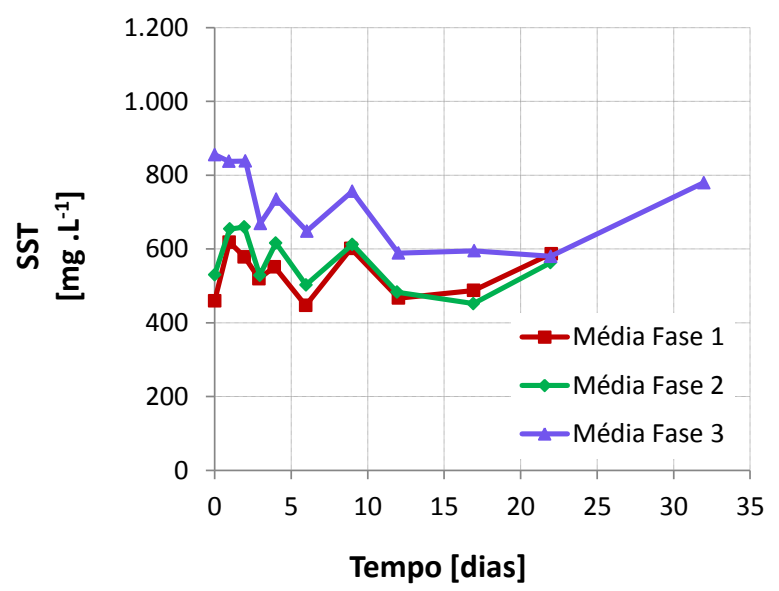

(e) Comparação entre as médias das Fases 1, 2 e 3

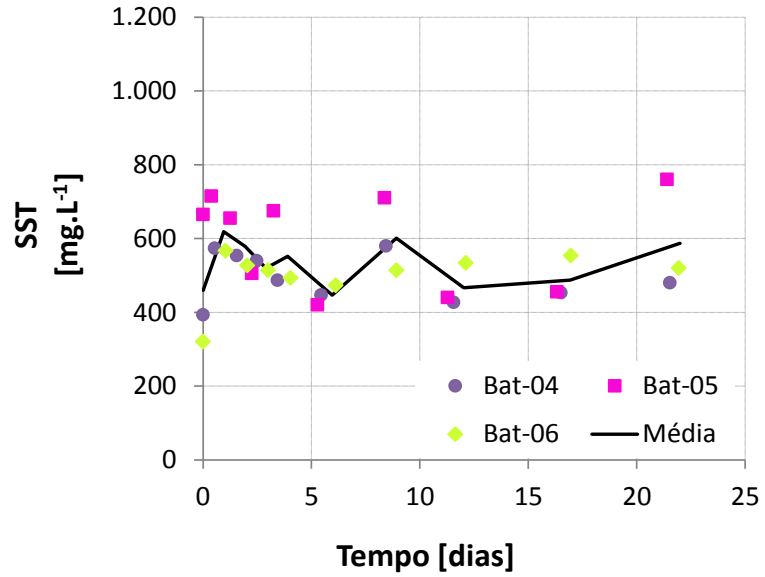

(b) Na Fase 1 a 12 ciclos por dia e $32^{\circ} \mathrm{C}$

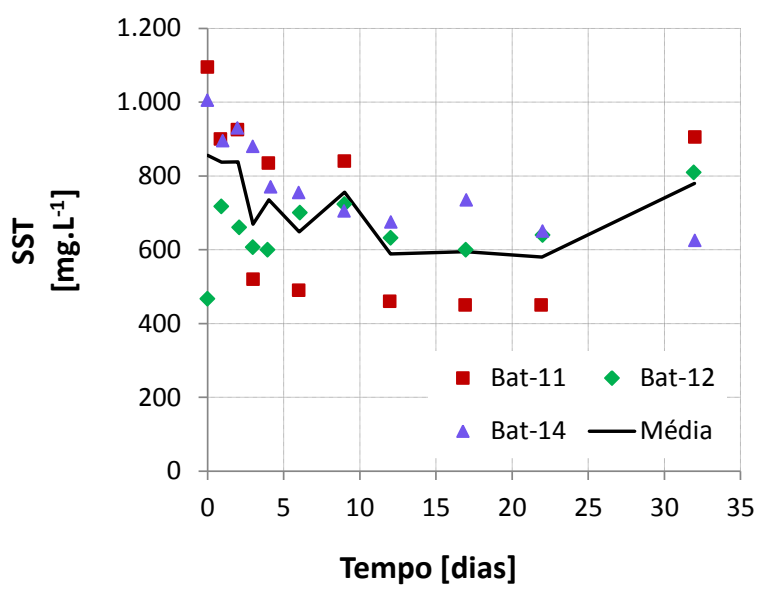

(d) Na Fase 3 a 24 ciclos por dia e $25^{\circ} \mathrm{C}$

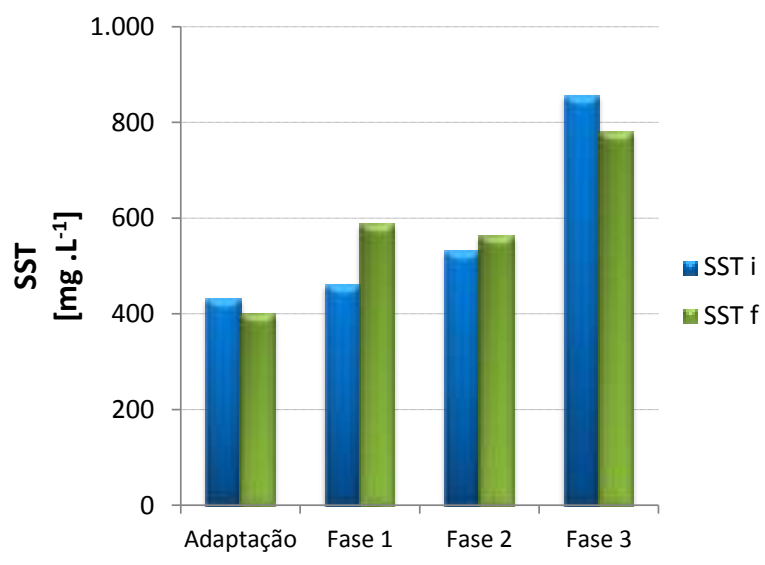

(f) Inicial e final nas quatro fases 
Figura 62 - Variações das concentrações de Sólidos Dissolvidos Totais nas diferentes fases do experimento.

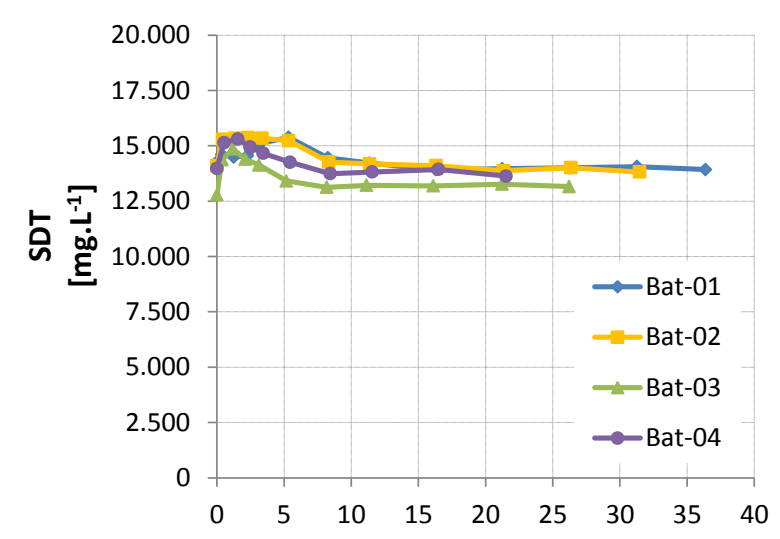

Tempo [dias]

(a) Na Fase de Adaptação

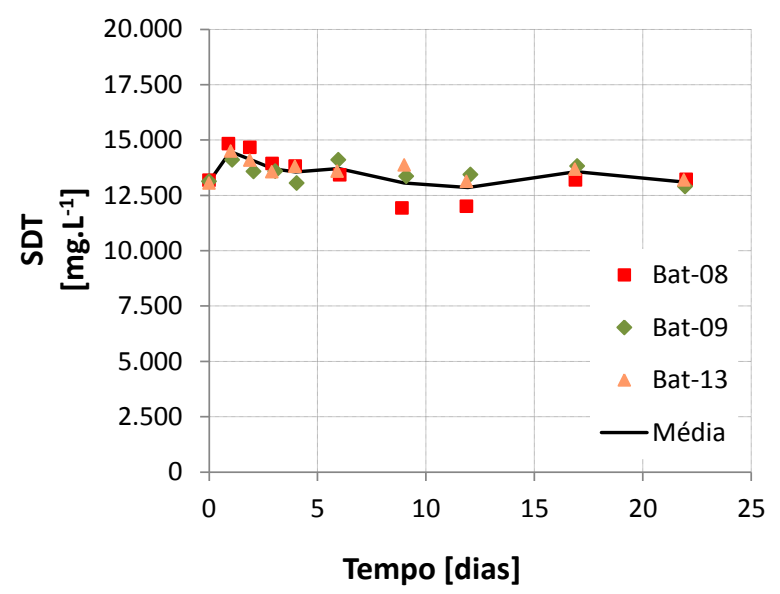

(c) Na Fase 2 a 24 ciclos por dia e $32^{\circ} \mathrm{C}$

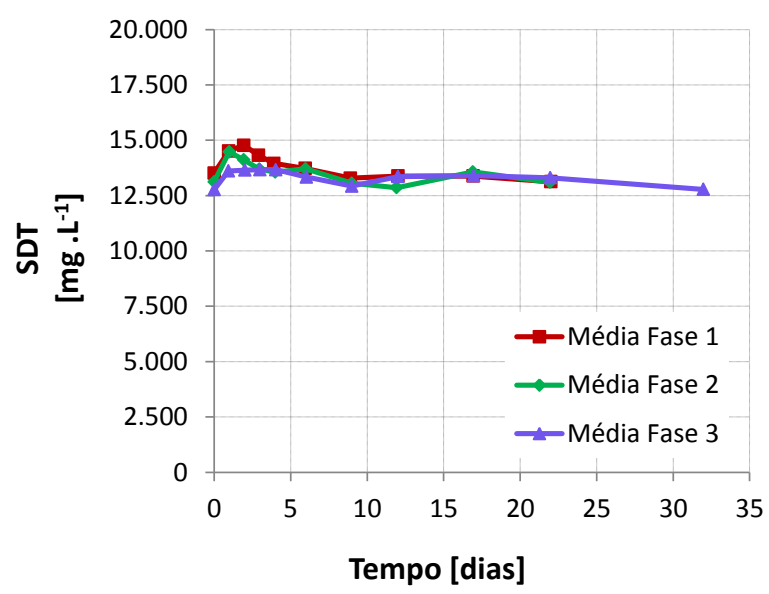

(e) Comparação entre as médias das Fases 1, 2 e 3

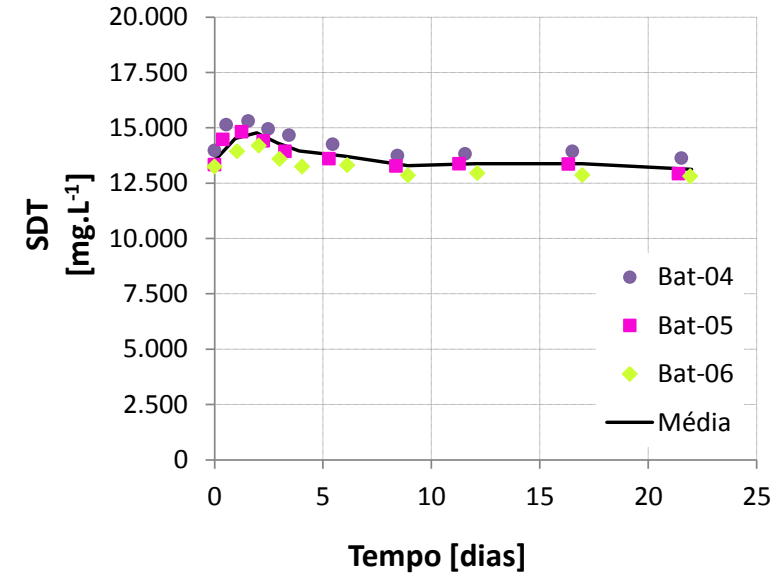

(b) Na Fase 1 a 12 ciclos por dia e $32^{\circ} \mathrm{C}$

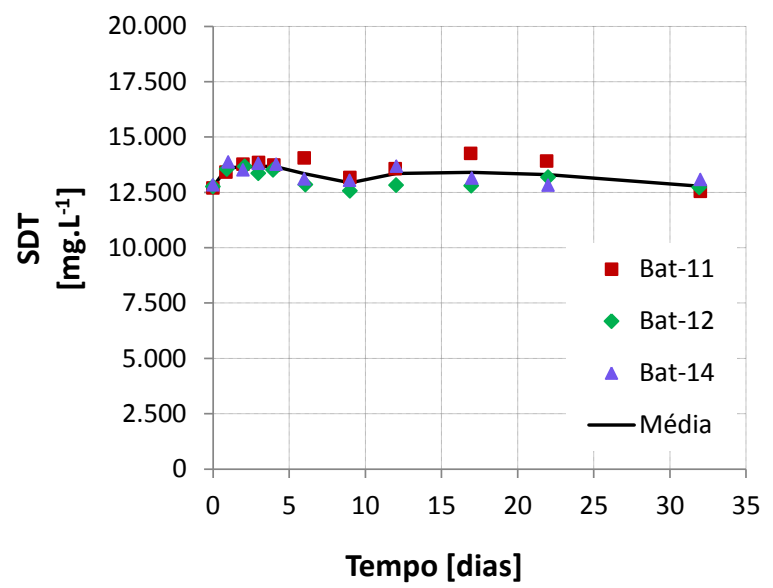

(d) Na Fase 3 a 24 ciclos por dia e $25^{\circ} \mathrm{C}$

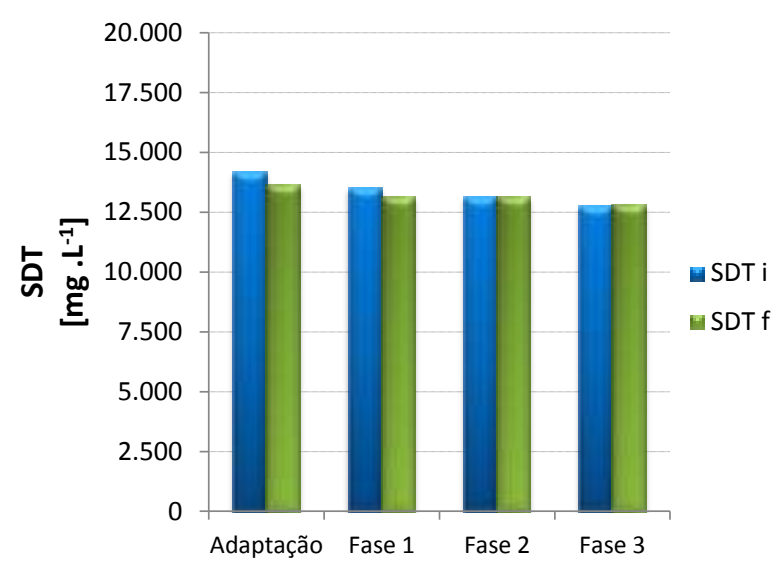

(f) Inicial e final nas quatro fases 


\section{Metais}

Figura 63 - Variações das concentrações de metais nas bateladas 04, 06 e 08: (a) Cromo; (b) Cobre; (c) Chumbo e (d) Níquel.

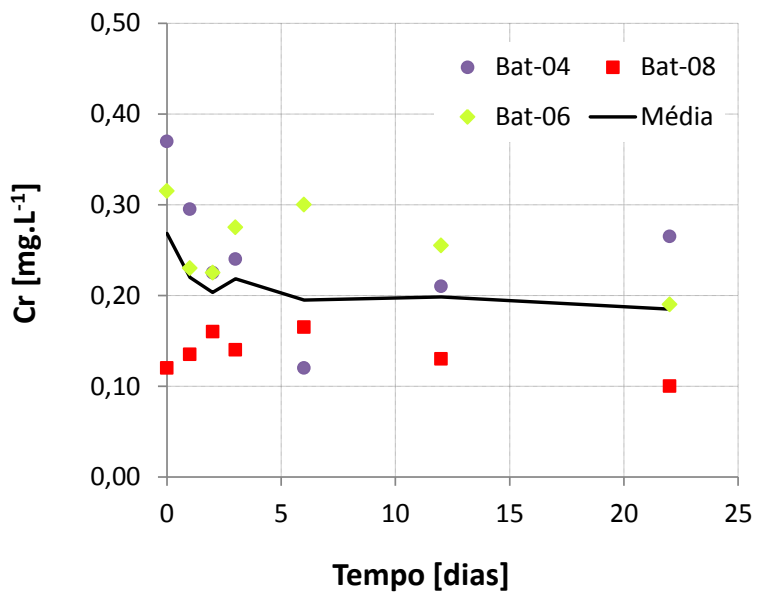

(a)

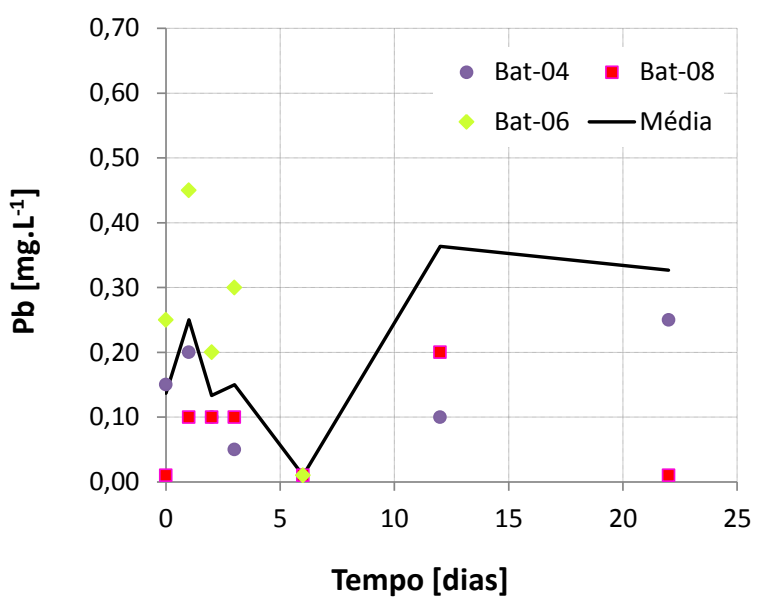

(c)

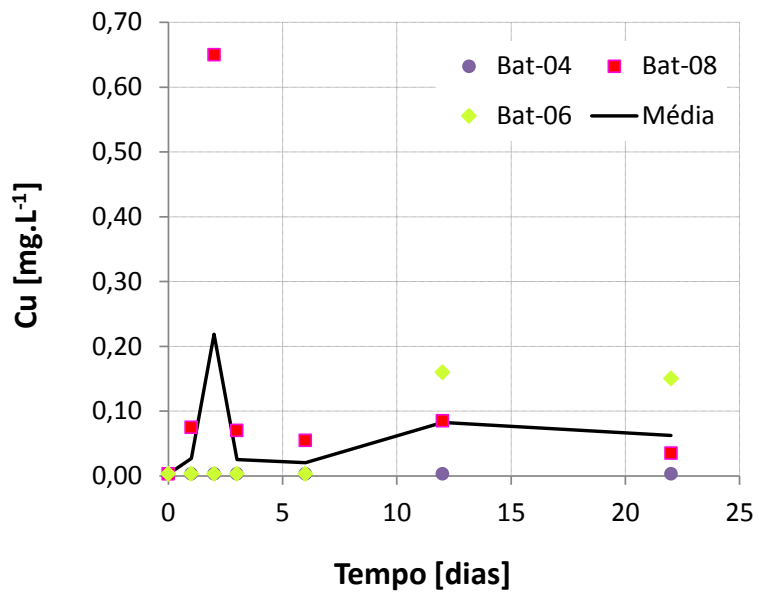

(b)

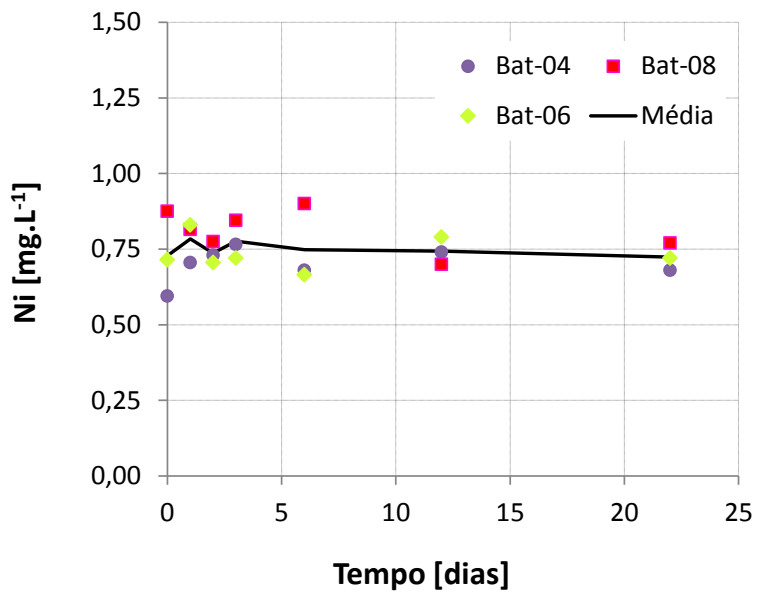

(d) 
Figura 64 - Variações das concentrações de metais nas bateladas 04, 06 e 08: (a) Zinco; (b) Selênio; (c) ) Sódio e (d) Potássio.

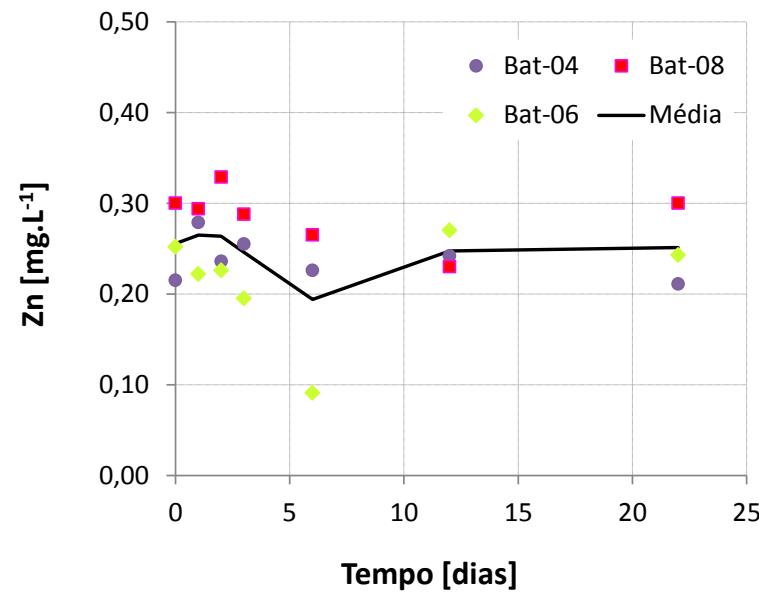

(a)

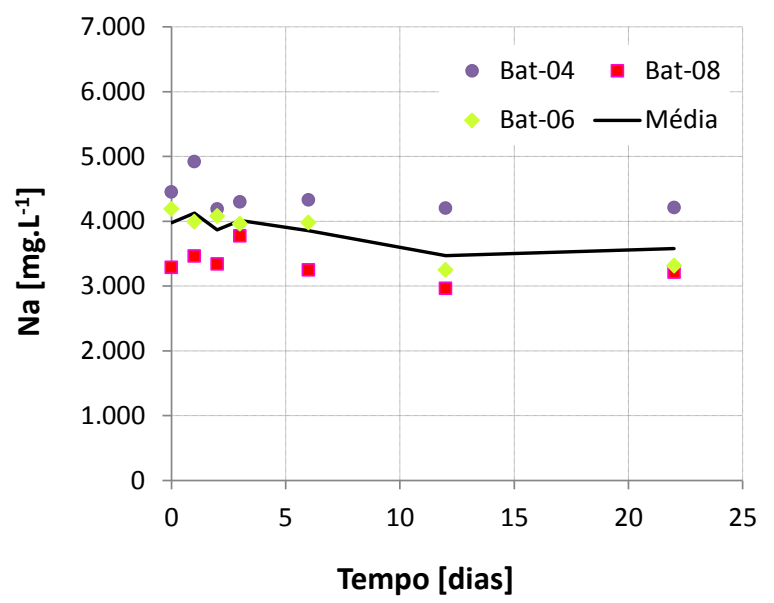

(c)

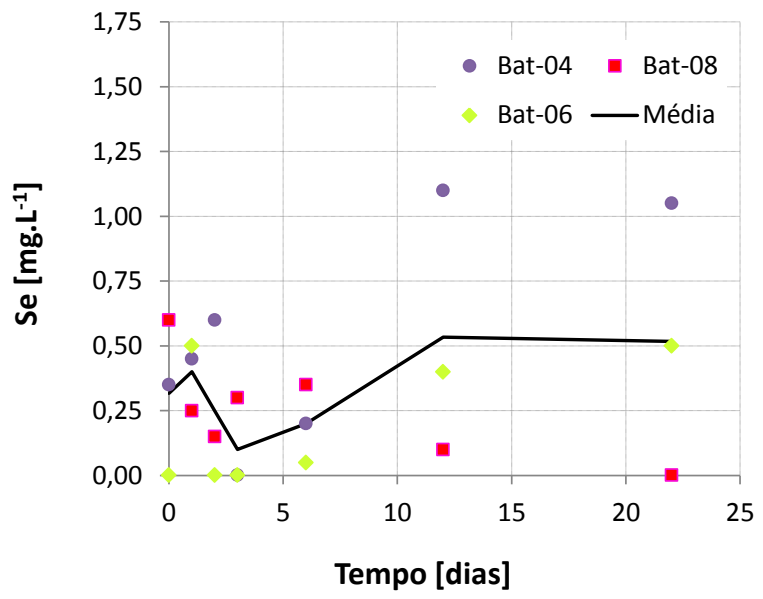

(b)

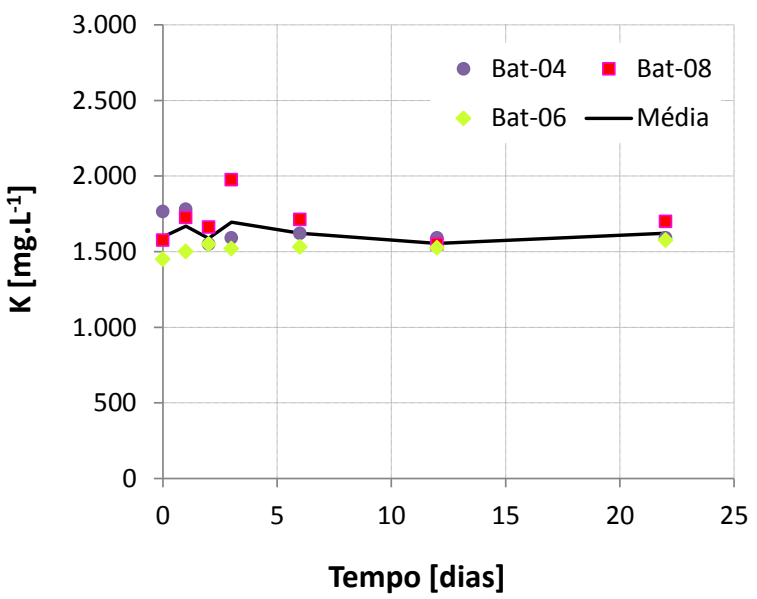

(d) 
Figura 65 - Variações das concentrações de Sódio nas diferentes fases do experimento.

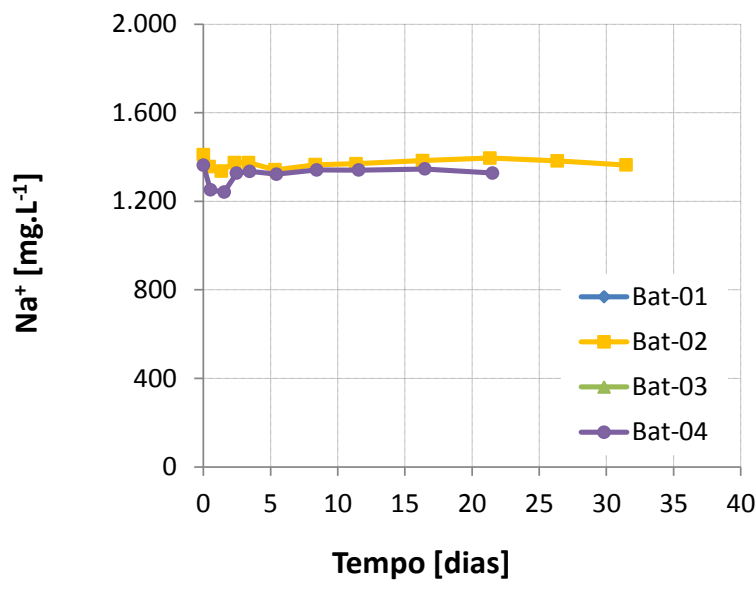

(a) Na Fase de Adaptação

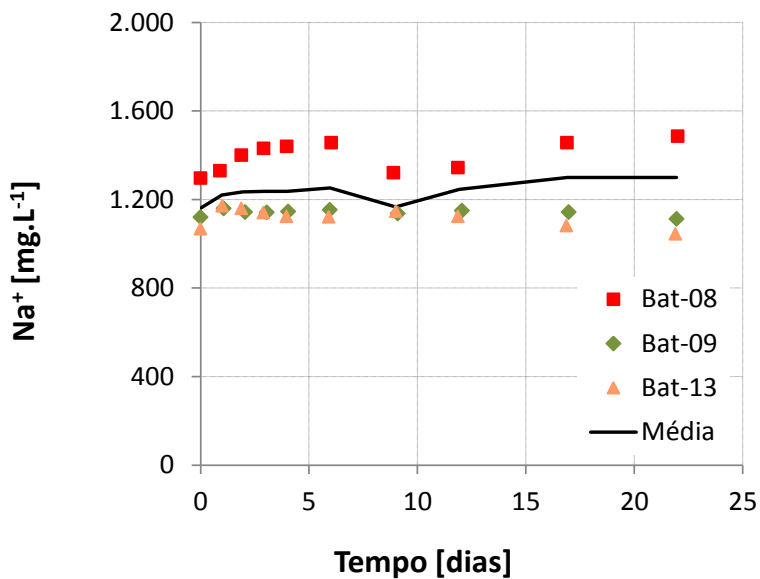

(c) Na Fase 2 a 24 ciclos por dia e $32^{\circ} \mathrm{C}$

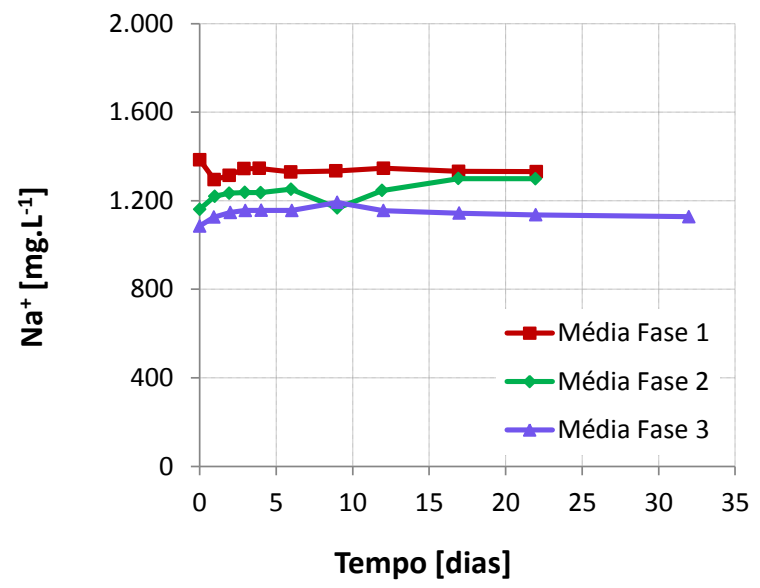

(e) Comparação entre as médias das Fases 1, 2 e 3

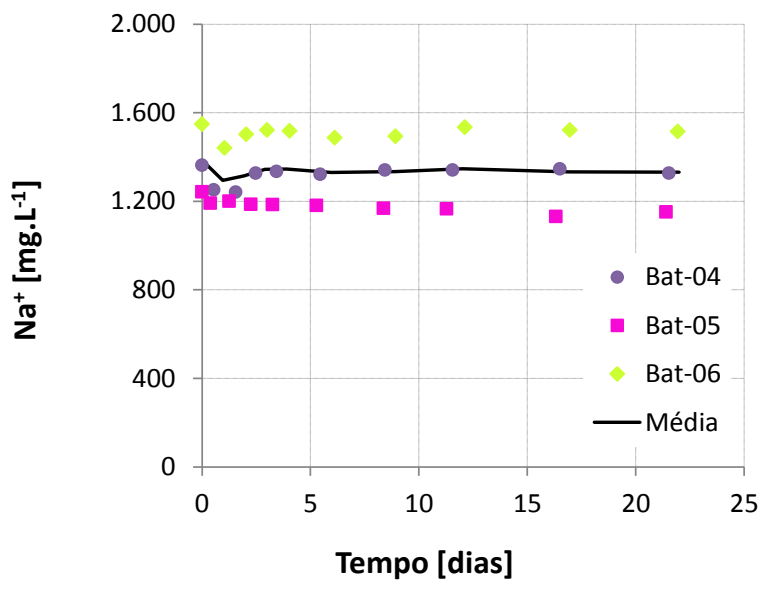

(b) Na Fase 1 a 12 ciclos por dia e $32^{\circ} \mathrm{C}$

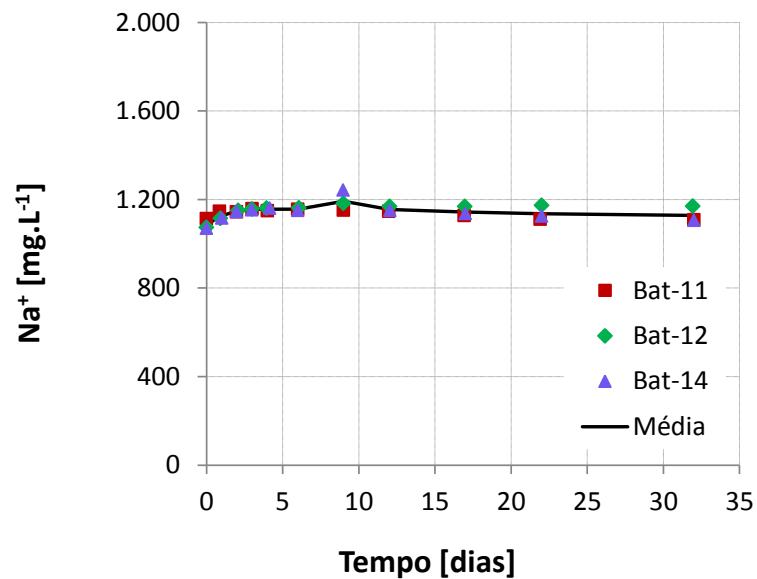

(d) Na Fase 3 a 24 ciclos por dia e $25^{\circ} \mathrm{C}$

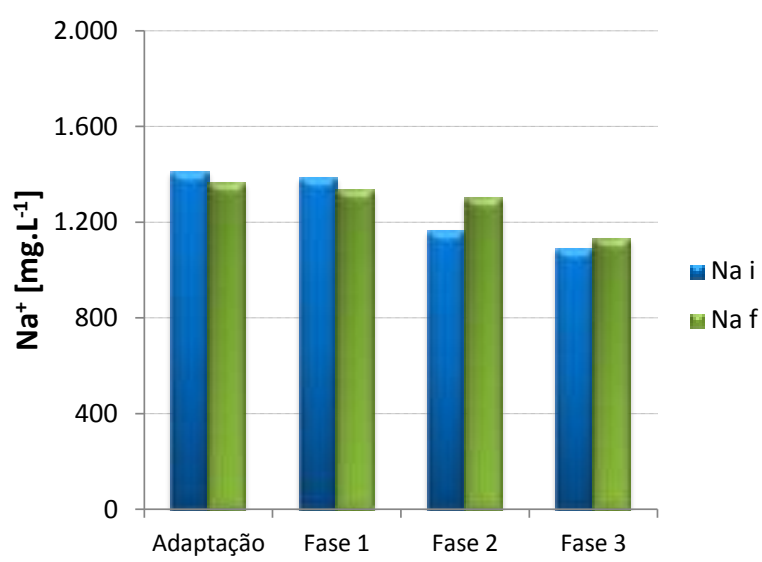

(f) Inicial e final nas quatro fases 
Figura 66 - Variações das concentrações de Potássio nas diferentes fases do experimento.

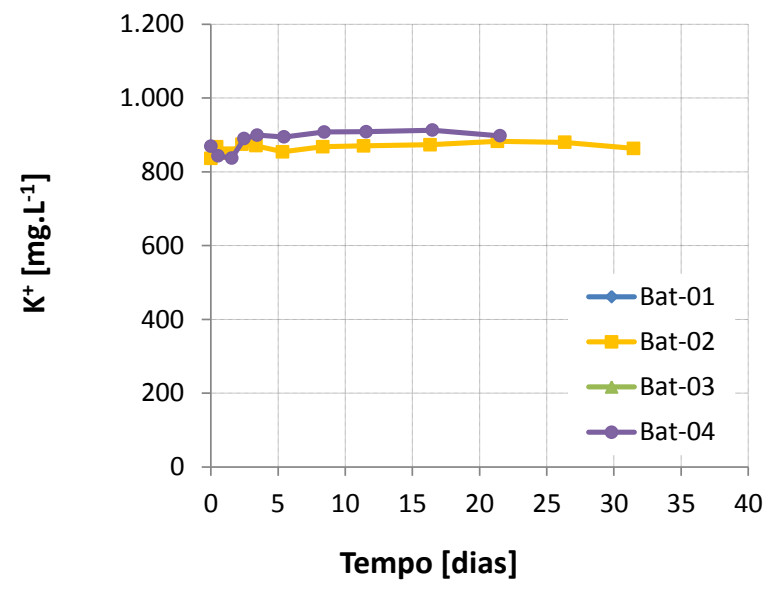

(a) Na Fase de Adaptação

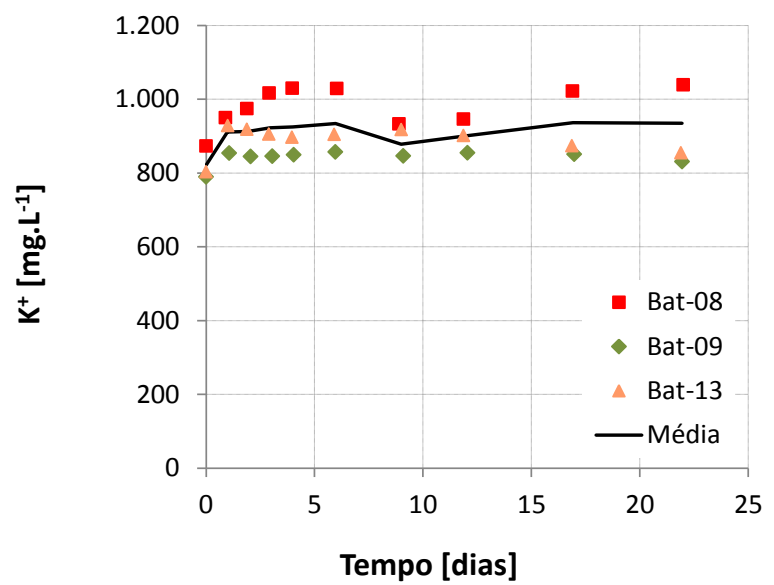

(c) Na Fase 2 a 24 ciclos por dia e $32^{\circ} \mathrm{C}$

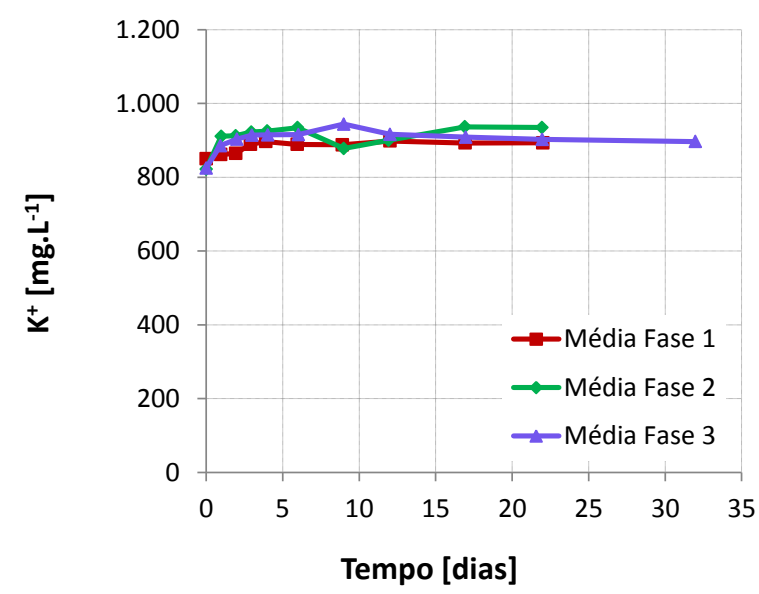

(e) Comparação entre as médias das Fases 1, 2 e 3

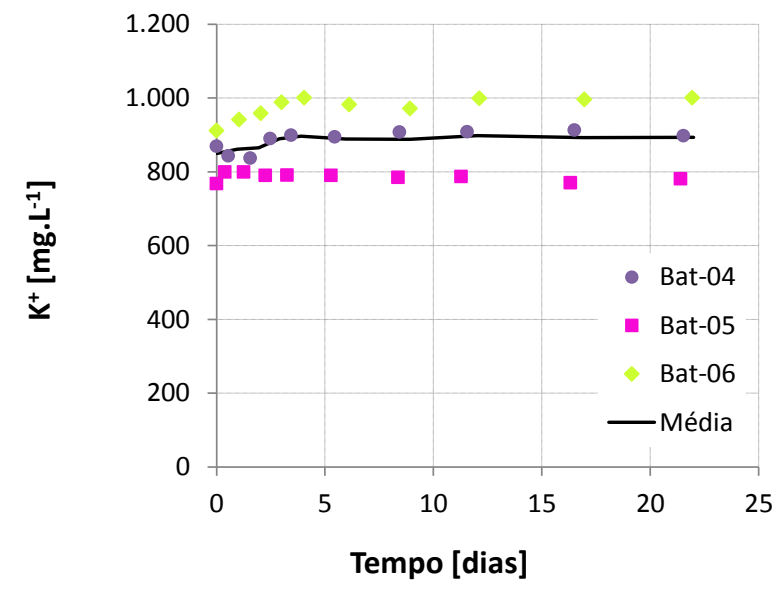

(b) Na Fase 1 a 12 ciclos por dia e $32^{\circ} \mathrm{C}$

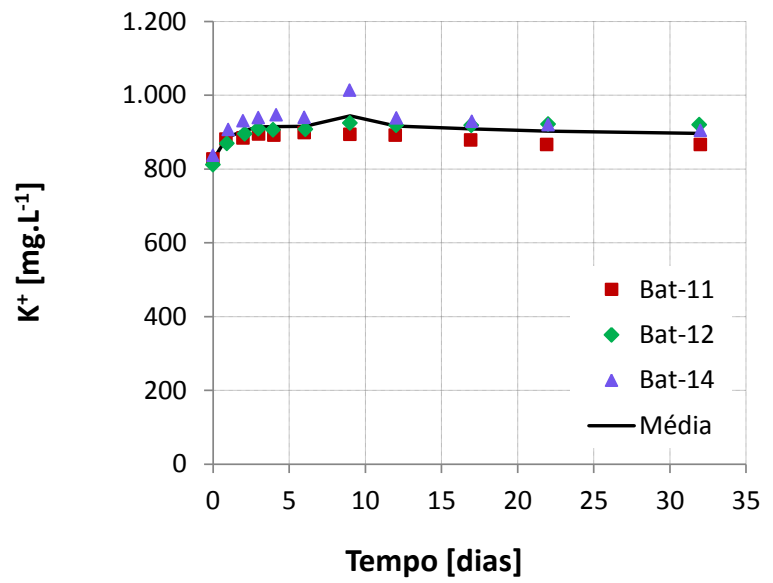

(d) Na Fase 3 a 24 ciclos por dia e $25^{\circ} \mathrm{C}$

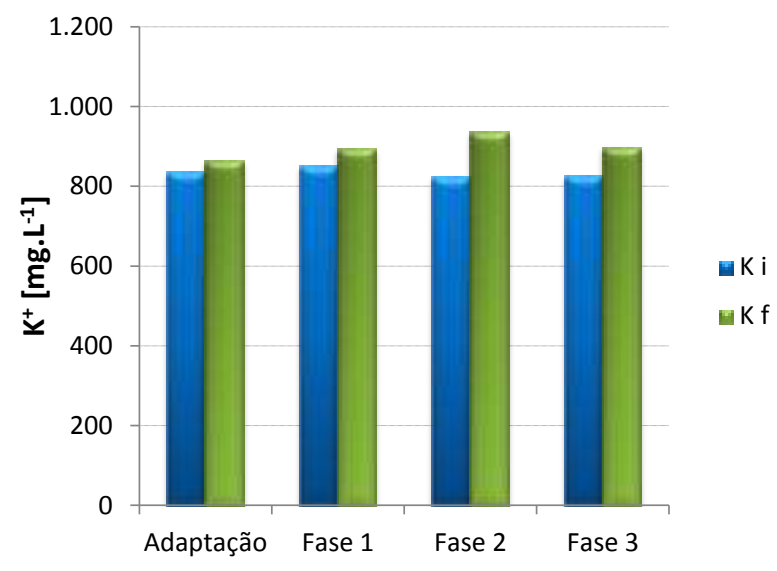

(f) Inicial e final nas quatro fases 
Figura 67 - Variações das concentrações de Cálcio nas diferentes fases do experimento.

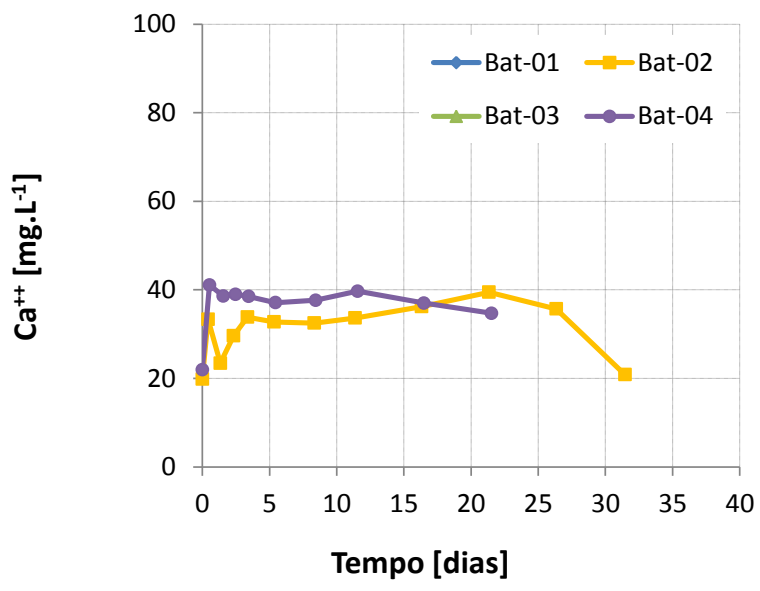

(a) Na Fase de Adaptação

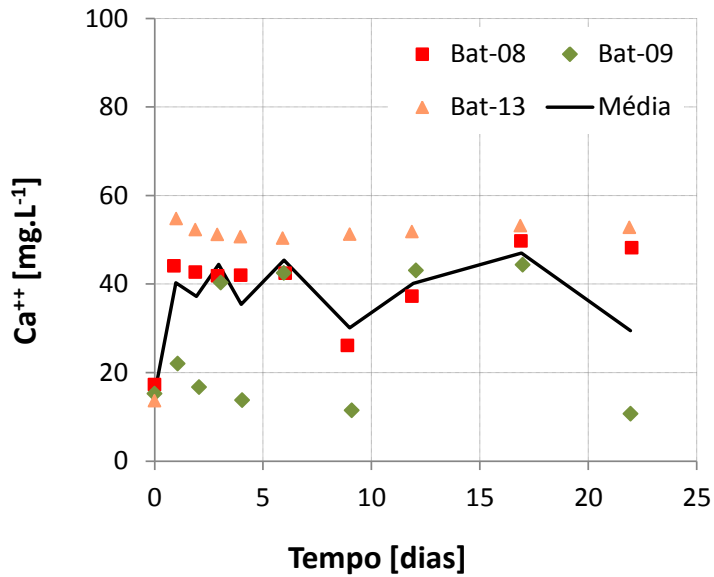

(c) Na Fase 2 a 24 ciclos por dia e $32^{\circ} \mathrm{C}$

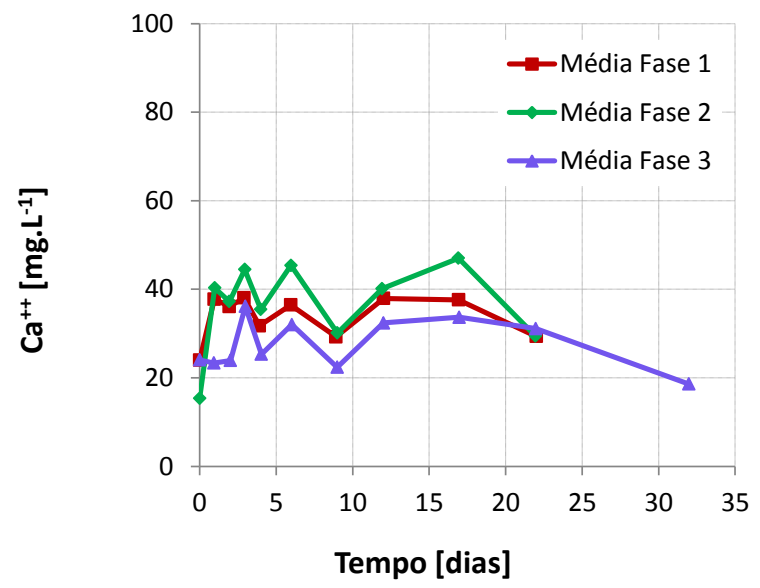

(e) Comparação entre as médias das Fases 1, 2 e 3

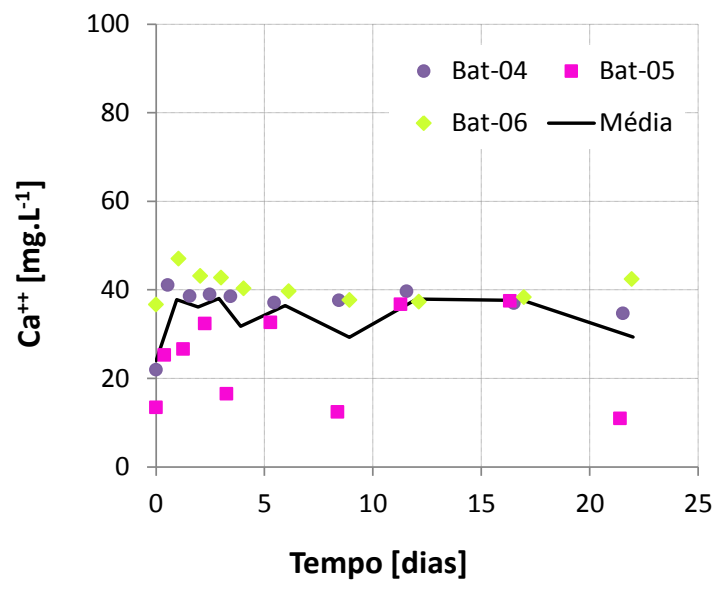

(b) Na Fase 1 a 12 ciclos por dia e $32^{\circ} \mathrm{C}$

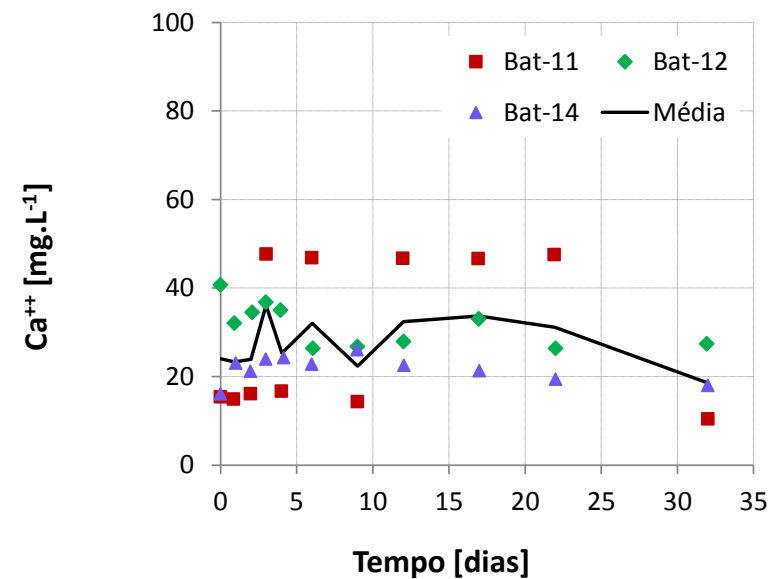

(d) Na Fase 3 a 24 ciclos por dia e $25^{\circ} \mathrm{C}$

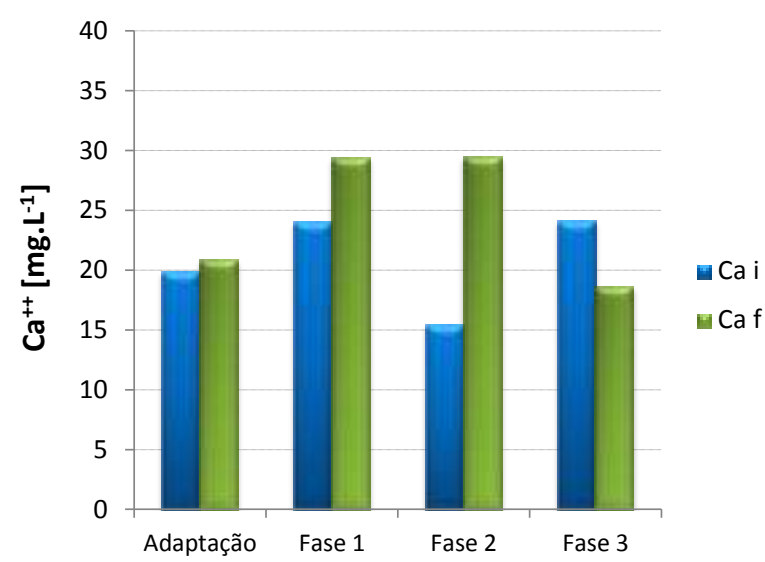

(f) Inicial e final nas quatro fases 
Figura 68 - Variações das concentrações de Magnésio nas diferentes fases do experimento.

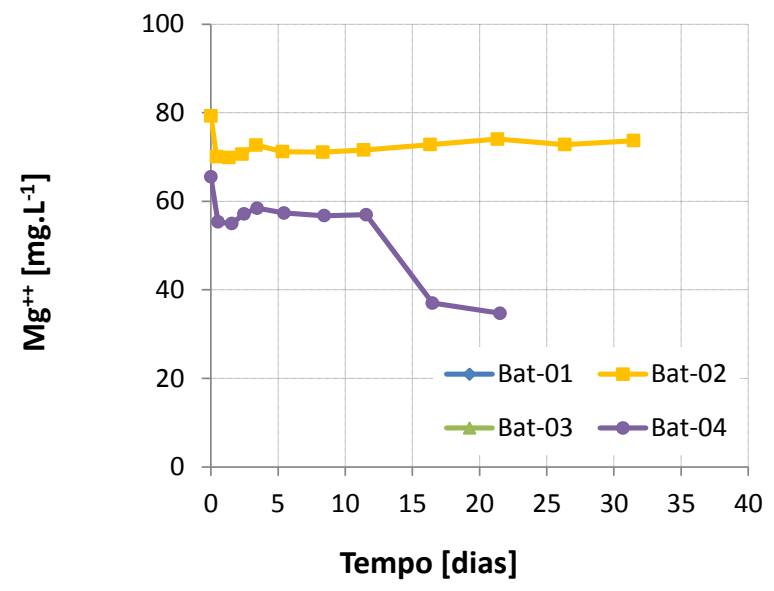

(a) Na Fase de Adaptação

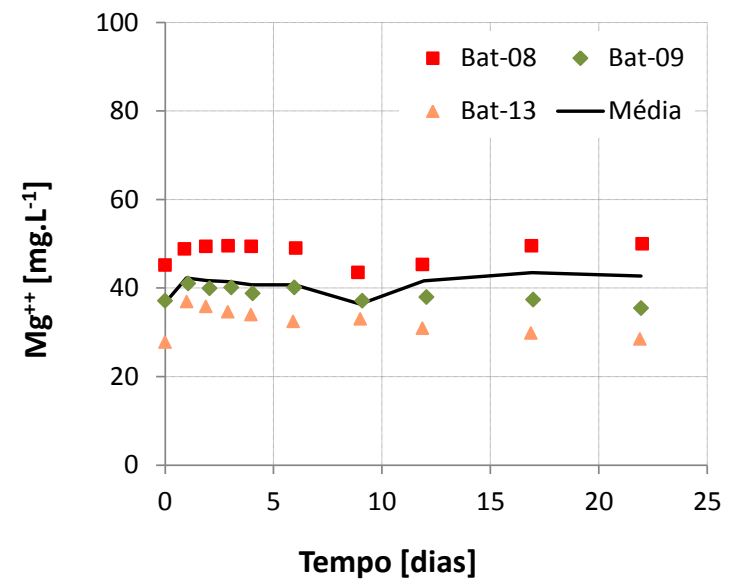

(c) Na Fase 2 a 24 ciclos por dia e $32^{\circ} \mathrm{C}$

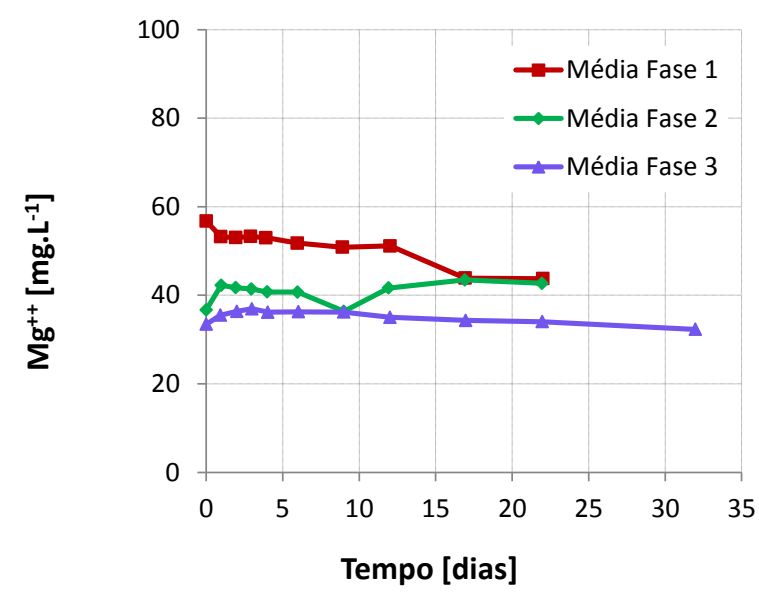

(e) Comparação entre as médias das Fases 1, 2 e 3

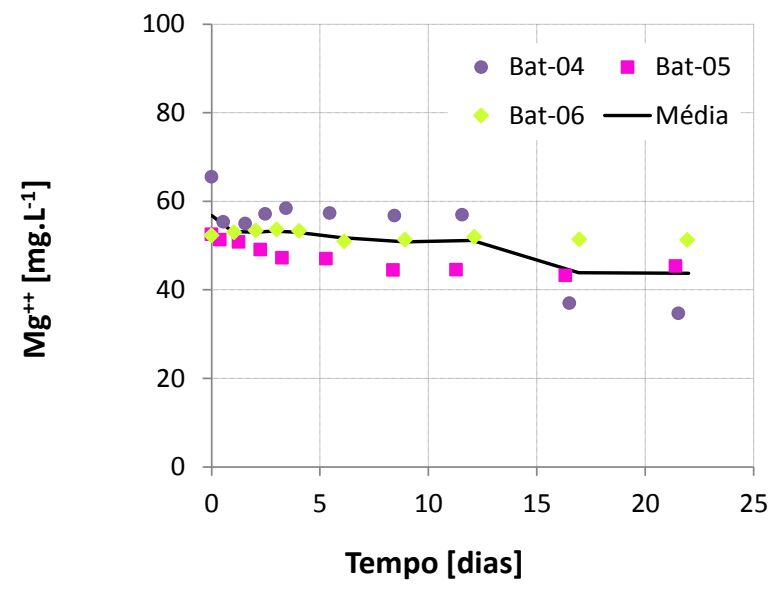

(b) Na Fase 1 a 12 ciclos por dia e $32^{\circ} \mathrm{C}$

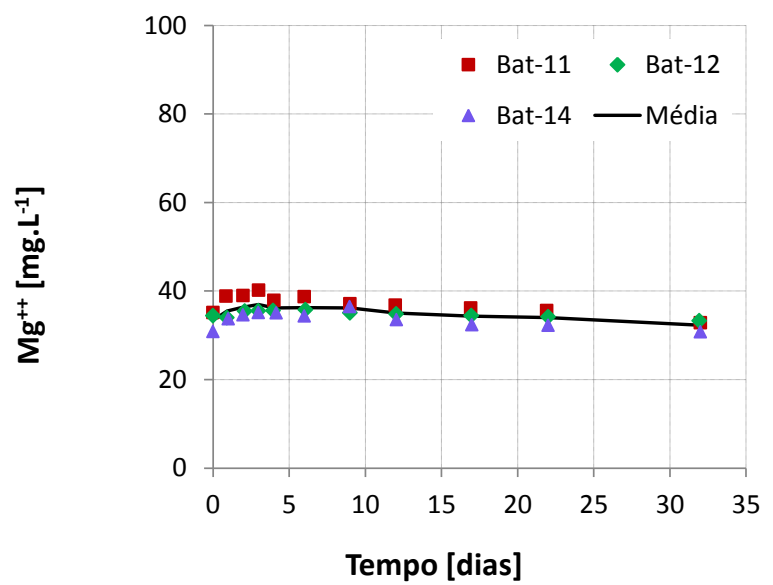

(d) Na Fase 3 a 24 ciclos por dia e $25^{\circ} \mathrm{C}$

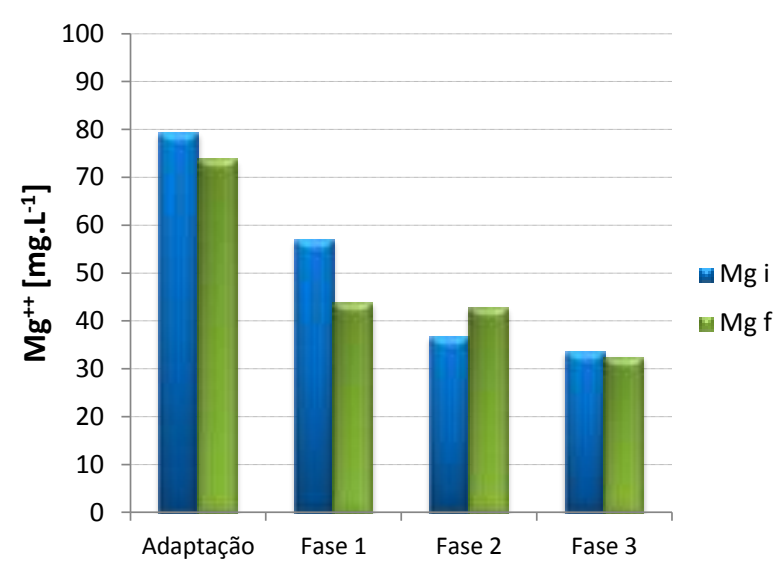

(f) Inicial e final nas quatro fases 